\title{
Oral versus intra-vaginal imidazole and triazole anti-fungal treatment of uncomplicated vulvovaginal candidiasis (thrush)
} (Review)

Denison HJ, Worswick J, Bond CM, Grimshaw JM, Mayhew A, Gnani Ramadoss S, Robertson C, Schaafsma ME, Watson MC

Denison HJ, Worswick J, Bond CM, Grimshaw JM, Mayhew A, Gnani Ramadoss S, Robertson C, Schaafsma ME, Watson MC. Oral versus intra-vaginal imidazole and triazole anti-fungal treatment of uncomplicated vulvovaginal candidiasis (thrush). Cochrane Database of Systematic Reviews 2020, Issue 8. Art. No.: CD002845. DOI: 10.1002/14651858.CD002845.pub3.

www.cochranelibrary.com 
TABLE OF CONTENTS

HEADER

ABSTRACT

PLAIN LANGUAGE SUMMARY

SUMMARY OF FINDINGS

BACKGROUND

OBJECTIVES

METHODS

RESULTS

Figure 1.

Figure 2.

Figure 3.

Figure 4.

Figure 5.

Figure 6.

Figure 7.

Figure 8.

DISCUSSION

AUTHORS' CONCLUSIONS

ACKNOWLEDGEMENTS

REFERENCES

CHARACTERISTICS OF STUDIES

DATA AND ANALYSES

Analysis 1.1. Comparison 1: Oral versus Intra-vaginal, Outcome 1: Clinical cure (short term)

Analysis 1.2. Comparison 1: Oral versus Intra-vaginal, Outcome 2: Clinical cure (long term)

Analysis 1.3. Comparison 1: Oral versus Intra-vaginal, Outcome 3: Mycological cure (short term)

Analysis 1.4. Comparison 1: Oral versus Intra-vaginal, Outcome 4: Mycological cure (long term)

Analysis 1.5. Comparison 1: Oral versus Intra-vaginal, Outcome 5: Safety - number of withdrawals due to adverse events .......

Analysis 1.6. Comparison 1: Oral versus Intra-vaginal, Outcome 6: Side effects

Analysis 1.7. Comparison 1: Oral versus Intra-vaginal, Outcome 7: Treatment preference

Analysis 1.8. Comparison 1: Oral versus Intra-vaginal, Outcome 8: Time to first relief

Analysis 2.1. Comparison 2: Oral versus Intra-vaginal (no. randomised), Outcome 1: Clinical cure (short term)

Analysis 2.2. Comparison 2: Oral versus Intra-vaginal (no. randomised), Outcome 2: Clinical cure (long term)

Analysis 2.4. Comparison 2: Oral versus Intra-vaginal (no. randomised), Outcome 4: Mycological cure (long term) ...................

Analysis 2.5. Comparison 2: Oral versus Intra-vaginal (no. randomised), Outcome 5: Side effects

Analysis 3.1. Comparison 3: Single-dose oral therapy versus 3 days intra-vaginal therapy, Outcome 1: Mycological cure (short term)

Analysis 3.2. Comparison 3: Single-dose oral therapy versus 3 days intra-vaginal therapy, Outcome 2: Mycological cure (long term)

Analysis 4.1. Comparison 4: Single-dose oral anti-fungal therapy versus single-dose intra-vaginal anti-fungal therapy, Outcome 1: Clinical cure (short term)

Analysis 4.2. Comparison 4: Single-dose oral anti-fungal therapy versus single-dose intra-vaginal anti-fungal therapy, Outcome 2: Clinical cure (long term)

Analysis 4.3. Comparison 4: Single-dose oral anti-fungal therapy versus single-dose intra-vaginal anti-fungal therapy, Outcome 3: Mycological cure (short term)

Analysis 5.1. Comparison 5: Single-dose oral therapy versus 6-7 day intra-vaginal therapy, Outcome 1: Clinical cure (short term)

Analysis 5.2. Comparison 5: Single-dose oral therapy versus 6-7 day intra-vaginal therapy, Outcome 2: Clinical cure (long term)

Analysis 5.3. Comparison 5: Single-dose oral therapy versus 6-7 day intra-vaginal therapy, Outcome 3: Mycological cure (short term)

Analysis 5.4. Comparison 5: Single-dose oral therapy versus 6-7 day intra-vaginal therapy, Outcome 4: Mycological cure (long term) 
Analysis 5.5. Comparison 5: Single-dose oral therapy versus 6-7 day intra-vaginal therapy, Outcome 5: Side effects

Analysis 6.1. Comparison 6: Fluconazole versus Clotrimazole, Outcome 1: Long term clinical cure

Analysis 6.2. Comparison 6: Fluconazole versus Clotrimazole, Outcome 2: Long term mycological cure ......................................95

ADDITIONAL TABLES

APPENDICES

WHAT'S NEW

HISTORY

DECLARATIONS OF INTEREST

SOURCES OF SUPPORT 
[Intervention Review]

\section{Oral versus intra-vaginal imidazole and triazole anti-fungal treatment of uncomplicated vulvovaginal candidiasis (thrush)}

Hayley J Denison ${ }^{1}$, Julia Worswick², Christine M Bond³ , Jeremy M Grimshaw4, Alain Mayhew5 ${ }^{5}$, Shakila Gnani Ramadoss ${ }^{6}$, Clare Robertson7, Mary Ellen Schaafsma8, Margaret C Watson 9

${ }^{1}$ Centre for Public Health Research, Massey University - Wellington Campus, Wellington, New Zealand. 20ttawa Hospital Research Institute, The Ottawa Hospital, Ottawa, Canada. ${ }^{3}$ Division of Applied Health Sciences, University of Aberdeen, Aberdeen, UK. ${ }^{4} \mathrm{Clinical}$ Epidemiology Program, Ottawa Hospital Research Institute, Ottawa, Canada. ${ }^{5}$ Bruyere Research Institute, Ottawa, Canada. 6 Health Services Research Unit, University of Aberdeen, Aberdeen, UK. ${ }^{7}$ Health Services Research Unit, University of Aberdeen, Aberdeen, UK. ${ }^{8}$ Social Purpose Institute, United Way of the Lower Mainland, Burnaby, Canada. ${ }^{9}$ Strathclyde Institute of Pharmacy and Biomedical Sciences, University of Strathclyde, Glasgow, UK

Contact address: Jeremy M Grimshaw, jgrimshaw@ohri.ca, jgrimshaw2@mac.com.

Editorial group: Cochrane STI Group.

Publication status and date: New search for studies and content updated (no change to conclusions), published in Issue 8, 2020.

Citation: Denison HJ, Worswick J, Bond CM, Grimshaw JM, Mayhew A, Gnani Ramadoss S, Robertson C, Schaafsma ME, Watson MC. Oral versus intra-vaginal imidazole and triazole anti-fungal treatment of uncomplicated vulvovaginal candidiasis (thrush). Cochrane Database of Systematic Reviews 2020, Issue 8. Art. No.: CD002845. DOI: 10.1002/14651858.CD002845.pub3.

Copyright @ 2020 The Cochrane Collaboration. Published by John Wiley \& Sons, Ltd.

\section{A B S T R A C T}

\section{Background}

Anti-fungals are available for oral and intra-vaginal treatment of uncomplicated vulvovaginal candidiasis.

\section{Objectives}

The primary objective of this review is to assess the relative effectiveness (clinical cure) of oral versus intra-vaginal anti-fungals for the treatment of uncomplicated vulvovaginal candidiasis. Secondary objectives include the assessment of the relative effectiveness in terms of mycological cure, in addition to safety, side effects, treatment preference, time to first relief of symptoms, and costs.

\section{Search methods}

We searched CENTRAL, MEDLINE, Embase, and two trials registers on 29 August 2019 together with reference checking and citation searching.

\section{Selection criteria}

We included randomised controlled trials published in any language comparing at least one oral anti-fungal with one intra-vaginal antifungal in women (aged 16 years or over) with a mycological diagnosis (positive culture, microscopy for yeast, or both) of uncomplicated vulvovaginal candidiasis. We excluded trials if they solely involved participants who were HIV positive, immunocompromised, pregnant, breast feeding or diabetic.

\section{Data collection and analysis}

We used standard methodological procedures as recommended by Cochrane.

\section{Main results}

This review includes 26 trials (5007 participants). Eight anti-fungals are represented. All but three trials included participants with acute vulvovaginal candidiasis. Trials were conducted in Europe: UK (3), Croatia (2). Finland (2), the Netherlands (2), Germany (1), Italy (1), Sweden 
(1) and one trial across multiple European countries, USA (7) Thailand (2), Iran (2), Japan (1) and Africa (Nigeria) (1). The duration of followup varied between trials. The overall risk of bias of the included trials was high.

There was probably little or no difference shown between oral and intra-vaginal anti-fungal treatment for clinical cure at short-term followup (OR 1.14, $95 \% \mathrm{Cl} 0.91$ to $1.43 ; 13$ trials; 1859 participants; moderate-certainty evidence) and long-term follow-up (OR 1.07, $95 \%$ Cl 0.77 to 1.50; 9 trials; 1042 participants; moderate-certainty evidence). The evidence suggests that if the rate of clinical cure at short-term followup with intra-vaginal treatment is $77 \%$, the rate with oral treatment would be between $75 \%$ and $83 \%$; if the rate of clinical cure at long term follow-up with intra-vaginal treatment is $84 \%$, the rate with oral treatment would be between $80 \%$ and $89 \%$. Oral treatment probably improves mycological cure over intra-vaginal treatment at short term (OR 1.24, 95\% Cl 1.03 to 1.50: 19 trials; 3057 participants; moderatecertainty evidence) and long-term follow-up (OR 1.29, 95\% Cl 1.05 to $1.60 ; 13$ trials; 1661 participants; moderate-certainty evidence). The evidence suggests that if the rate of mycological cure at short-term follow-up with intra-vaginal treatment is $80 \%$, the rate with oral treatment would be between $80 \%$ and $85 \%$; if the rate of mycological cure at long-term follow-up with intra-vaginal treatment is $66 \%$, the rate with oral treatment would be between $67 \%$ and $76 \%$.

In terms of patient safety, there is a low risk of participants withdrawing from the studies due to adverse drug effects for either treatment (23 trials; 4637 participants; high-certainty evidence). Due to the low certainty of evidence, it is undetermined whether oral treatments reduced the number of side effects compared with intra-vaginal treatments (OR 1.04, 95\% CI 0.84 to 1.29; 16 trials; 3155 participants; lowcertainty evidence). The evidence suggests that if the rate of side effects with intra-vaginal treatment is $12 \%$, the rate with oral treatment would be between $10 \%$ and $15 \%$. We noted that the type of side effects differed, with intra-vaginal treatments being more often associated with local reactions, and oral treatments being more often associated with systemic effects including gastro-intestinal symptoms and headaches. Oral treatment appeared to be the favoured treatment preference over intra-vaginal treatment or no preference (12 trials; 2206 participants), however the data were poorly reported and the certainty of the evidence was low. There was little or no difference in time to first relief of symptoms between oral and intra-vaginal treatments: four trials favoured the oral treatment, four favoured intra-vaginal, one study reported no difference and one was unclear. The measurements varied between the 10 trials (1910 participants) and the certainty of the evidence was low. Costs were not reported in any of the trials.

\section{Authors' conclusions}

Oral anti-fungal treatment probably improves short- and long-term mycological cure over intra-vaginal treatment for uncomplicated vaginal candidiasis. Oral treatment was the favoured treatment preference by participants, though the certainty of this evidence is low.

The decision to prescribe or recommend an anti-fungal for oral or intra-vaginal administration should take into consideration safety in terms of withdrawals and side effects, as well as cost and treatment preference. Unless there is a previous history of adverse reaction to one route of administration or contraindications, women who are purchasing their own treatment should be given full information about the characteristics and costs of treatment to make their own decision. If health services are paying the treatment cost, decision-makers should consider whether the higher cost of some oral anti-fungals is worth the gain in convenience, if this is the patient's preference.

\section{PLAIN LANGUAGE SUMMARY}

\section{Do antifungal medicines for vaginal yeast infections (thrush) work better if taken by mouth (orally) or placed in the vagina (intravaginally)?}

\section{What is thrush?}

Thrush (also called candidiasis) is a common vaginal infection caused by a type of fungus called a yeast. Symptoms include itching and irritation around the vagina and a white discharge. Thrush is usually harmless but it can be uncomfortable.

Thrush is usually treated with antifungal medicines. These can be taken by mouth (orally) or placed in the vagina (intravaginally).

\section{Why we did this Cochrane Review}

We wanted to find out if oral antifungal medicines work better than intravaginal antifungal medicines to treat thrush infections.

\section{What did we do?}

We searched for studies of antifungal medicines to treat thrush that compared an oral antifungal with an intravaginal antifungal.

We looked for randomised controlled studies, in which the treatments received were decided at random, because these studies usually give the most reliable evidence about the effects of treatments.

We were interested in how well - and how fast - antifungal medicines could get rid of yeast infections and improve symptoms; whether they had any unwanted effects; and whether women preferred oral or intravaginal treatment.

Search date: we included evidence published up to 29 August 2019.

\section{What we found}

Oral versus intra-vaginal imidazole and triazole anti-fungal treatment of uncomplicated vulvovaginal candidiasis (thrush) (Review)

Copyright @ 2020 The Cochrane Collaboration. Published by John Wiley \& Sons, Ltd. 
We found 26 studies in 5007 women with thrush who were treated with antifungal medicines called azoles. The studies were conducted in Europe, the USA, Thailand, Iran, Japan and Nigeria. Eight azoles were studied: 2 oral (fluconazole and itraconazole) and 6 intravaginal (butoconazole, clotrimazole, econazole, miconazole, sertaconazole and terconazole).

The studies measured whether oral and intravaginal antifungal medicines led to:

- no symptoms (clinical cure);

- no yeasts found in the vagina (mycological cure); or

- unwanted effects that caused women to stop treatment.

No studies reported the costs of the oral or intravaginal antifungal medicines.

\section{What are the results of our review?}

Clinical cure (no symptoms) was similar for oral and intravaginal antifungal medicines in both the short term (5 to 15 days; 13 studies), and long term ( 2 to 12 weeks; 9 studies). Whether an antifungal medicine is oral or intravaginal probably makes little to no difference to getting rid of thrush symptoms.

However, oral antifungal medicines probably cleared yeast from the vagina (mycological cure) better than intravaginal ones in both the short term (19 studies) and long term (13 studies).

Only three women stopped using their antifungal medicine because of unwanted effects ( 23 studies); the risk of women stopping treatment with oral or intravaginal antifungal medicines is low.

The numbers of unwanted effects reported were similar: whether an antifungal medicine is oral or intravaginal might make little to no difference to unwanted effects (13 studies). Headache and digestive symptoms were more common with oral antifungal medicines; unwanted effects of intravaginal antifungals commonly affected only the vaginal area.

Our results suggested that women might prefer taking an oral antifungal medicine to an intravaginal one (12 studies).

Whether an antifungal medicine is oral or intravaginal may make little to no difference to how quickly thrush gets better.

\section{How reliable are these results?}

We are moderately confident in our findings for clinical and mycological cure of thrush. These results might change if further evidence becomes available. We are confident about the low risk of women stopping treatment because of unwanted effects of antifungal medicines, and further evidence is unlikely change this.

We are less confident about the numbers of unwanted effects, preferred treatment, and how quickly symptoms get better. These results are likely to change if further evidence becomes available.

Ten studies received support from pharmaceutical companies; this could have affected how the studies were designed, conducted and reported. The results from some studies varied widely and were not reported consistently; and the women knew which treatment they had, which could have affected the results reported.

\section{Conclusions}

Oral antifungal medicines probably clear yeast from the vagina better than intravaginal antifungal medicines, although there is probably little to no difference between them for getting rid of thrush symptoms.

The risk of women stopping treatment because of unwanted effects is low for both oral and intravaginal antifungal medicines. 


\section{SUMMARY OF FIN DINGS}

\section{Summary of findings 1. Oral versus intra-vaginal antifungal treatment of uncomplicated vulvovaginal candidiasis}

Oral versus intra-vaginal antifungal treatment of uncomplicated vulvovaginal candidiasis.

Patient or population: women aged 16 and over with uncomplicated vulvovaginal candidiasis

Settings: various settings (single and multi-centre obs/gyn or other outpatient clinics) in Europe, USA, Japan, Thailand, Iran, Africa/Nigeria

Intervention: oral antifungal treatment of uncomplicated vulvovaginal candidiasis (fluconazole and itraconazole)

Comparison: Intra-vaginal antifungal treatment of uncomplicated vulvovaginal candidiasis (butoconazole, clotrimazole, econazole, miconazole, sertaconazole and terconazole)

\begin{tabular}{|c|c|c|c|c|c|c|}
\hline \multirow[t]{2}{*}{ Outcomes } & \multicolumn{2}{|c|}{$\begin{array}{l}\text { Anticipated ab- } \\
\text { solute effects }{ }^{\star}(95 \% \\
\text { CI) }\end{array}$} & \multirow[t]{2}{*}{$\begin{array}{l}\text { Relative } \\
\text { effect } \\
(95 \% \mathrm{CI})\end{array}$} & \multirow{2}{*}{$\begin{array}{l}\text { No of } \\
\text { Partici- } \\
\text { pants } \\
\text { (stud- } \\
\text { ies) }\end{array}$} & \multirow{2}{*}{\multicolumn{2}{|c|}{$\begin{array}{l}\text { Certain- } \\
\text { ty of } \\
\text { the evi- } \\
\text { dence } \\
\text { (GRADE) }\end{array}$}} \\
\hline & $\begin{array}{l}\text { As- } \\
\text { sumed } \\
\text { control } \\
\text { risk (in- } \\
\text { tra-vagi- } \\
\text { nal } \\
\text { treat- } \\
\text { ment) }\end{array}$ & $\begin{array}{l}\text { Corre- } \\
\text { spond- } \\
\text { ing in- } \\
\text { terven- } \\
\text { tion risk } \\
\text { (oral } \\
\text { treat- } \\
\text { ment) }\end{array}$ & & & & \\
\hline $\begin{array}{l}\text { Clinical cure } \\
\text { (short term: } 5 \text { to } \\
15 \text { days) }\end{array}$ & $\begin{array}{l}767 \text { per } \\
1000\end{array}$ & $\begin{array}{l}790 \text { per } \\
1000 \\
(750 \text { to } \\
825)\end{array}$ & $\begin{array}{l}\text { OR } 1.14 \\
(0.91 \text { to } \\
1.43)\end{array}$ & $\begin{array}{l}1859 \\
\text { (13 RCTs) }\end{array}$ & $\begin{array}{l}\text { Moder- } \\
\text { ate }^{1} \oplus \oplus \oplus\end{array}$ & \\
\hline $\begin{array}{l}\text { Clinical cure (long } \\
\text { term; } 2 \text { to } 12 \\
\text { weeks) }\end{array}$ & $\begin{array}{l}838 \text { per } \\
1000\end{array}$ & $\begin{array}{l}847 \text { per } \\
1000 \\
(799 \text { to } \\
886)\end{array}$ & $\begin{array}{l}\text { OR } 1.07 \\
(0.77 \text { to } \\
1.50)\end{array}$ & $\begin{array}{l}1042 \\
\text { (9 RCTs) }\end{array}$ & $\begin{array}{l}\text { Moder- } \\
\text { ate }^{1} \oplus \oplus \oplus\end{array}$ & \\
\hline $\begin{array}{l}\text { Mycological cure } \\
\text { (short term; } 5 \text { to } \\
15 \text { days) }\end{array}$ & $\begin{array}{l}796 \text { per } \\
1000\end{array}$ & $\begin{array}{l}829 \text { per } \\
1000 \\
(801 \text { to } \\
854)\end{array}$ & $\begin{array}{l}\text { OR } 1.24 \\
(1.03 \text { to } \\
1.50)\end{array}$ & $\begin{array}{l}3057 \\
\text { (19 RCTs) }\end{array}$ & $\begin{array}{l}\text { Moder- } \\
\text { ate }^{1} \oplus \oplus \oplus\end{array}$ & \\
\hline
\end{tabular}




\begin{tabular}{|c|c|c|c|c|c|c|c|}
\hline 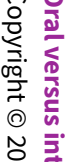 & $\begin{array}{l}\text { Mycological cure } \\
\text { (long term; } 2 \text { to } \\
12 \text { weeks) }\end{array}$ & $\begin{array}{l}662 \text { per } \\
1000\end{array}$ & $\begin{array}{l}716 \text { per } \\
1000 \\
(673 \text { to } \\
758)\end{array}$ & $\begin{array}{l}\text { OR } 1.29 \\
(1.05 \text { to } \\
1.60)\end{array}$ & $\begin{array}{l}1661 \\
\text { (13 RCTs) }\end{array}$ & \multicolumn{2}{|l|}{$\begin{array}{l}\text { Moder- } \\
\text { ate }^{1} \oplus \oplus \oplus\end{array}$} \\
\hline 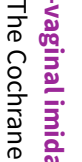 & $\begin{array}{l}\text { Safety (with- } \\
\text { drawals due to } \\
\text { adverse effects) }\end{array}$ & - & - & - & $\begin{array}{l}4637 \text { (23 } \\
\text { RCTs) }\end{array}$ & $\begin{array}{l}\text { High } \\
\oplus \oplus \oplus \oplus\end{array}$ & $\begin{array}{l}\text { Measured by number of withdrawals due to adverse reactions. Three trials reported with- } \\
\text { drawals due to adverse drug reactions (one participant in each trial). Two withdrawals } \\
\text { were from the intra-vaginal treatment group (both miconazole ACCELERATE 2002; Timo- } \\
\text { nen 1992a), and one was from the oral treatment group (fluconazole, Stein 1991) }\end{array}$ \\
\hline 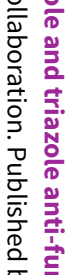 & $\begin{array}{l}\text { Side effects (pa- } \\
\text { tient-reported } \\
\text { side effects) }\end{array}$ & $\begin{array}{l}119 \text { per } \\
1000\end{array}$ & $\begin{array}{l}123 \text { per } \\
1000 \\
(102 \text { TO } \\
148)\end{array}$ & $\begin{array}{l}\text { OR } 1.04 \\
(\mathrm{Cl} 0.84 \\
\text { to } 1.29)\end{array}$ & $\begin{array}{l}3155 \text { (16 } \\
\text { RCTs) }\end{array}$ & $\begin{array}{l}\text { Low }^{1,2} \\
\oplus \oplus\end{array}$ & $\begin{array}{l}\text { Three trials were not included in the meta-analysis because they did not provide any in- } \\
\text { dication of the direction or magnitude of the relative treatment effect, as they reported } \\
\text { there were no side effect events for either treatment group (Mikamo 1995; Škerk V 2006; } \\
\text { Slavin 1992) Two further trials were also not included in the meta-analyses because they } \\
\text { did not provide numerical data about side effect events (Goode 1992; Roongpisuthipong } \\
\text { 2010). Lastly, Van Heusden } 1994 \text { was not included in the estimates because a denomina- } \\
\text { tor was unclear. }\end{array}$ \\
\hline 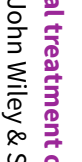 & $\begin{array}{l}\text { Treatment pref- } \\
\text { erence }\end{array}$ & - & - & - & $\begin{array}{l}2206 \\
\text { (12 RCTs) }\end{array}$ & $\begin{array}{l}\operatorname{Low}^{1,3} \\
\oplus \oplus\end{array}$ & $\begin{array}{l}\text { Poorly reported. Unable to determine preference in one trial (Tobin 1992). One study re- } \\
\text { ported no preference (Van Heusden 1990). } \\
\text { 10/12 studies preferred oral treatment (compared with intra-vaginal or no preference) }\end{array}$ \\
\hline 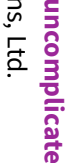 & $\begin{array}{l}\text { Time to first relief } \\
\text { of } \\
\text { symptoms }\end{array}$ & - & - & - & $\begin{array}{l}1910 \\
\text { (10 RCTs) }\end{array}$ & $\begin{array}{l}\operatorname{Low}^{1,4} \\
\oplus \oplus\end{array}$ & $\begin{array}{l}\text { Time to first relief measurements varied between studies. Four trials favoured intra-vagi- } \\
\text { nal (ACCELERATE 2002; Murina 2012;Seidman 2005; Slavin 1992. Two trials reported little } \\
\text { or no difference (Adetoro 1990; Mendling 2004), and one study showed mixed effects (Ti- } \\
\text { monen 1992a) }\end{array}$ \\
\hline & Costs & \multicolumn{5}{|c|}{ Not reported in any study } & - \\
\hline$\frac{\sqrt{2}}{\frac{9}{20}}$ & \multicolumn{7}{|c|}{$\begin{array}{l}\text { *The corresponding risk (and its } 95 \% \text { confidence interval) is based on the assumed risk in the comparison group and the relative effect of the intervention (and its } 95 \% \\
\mathrm{Cl} \text { ). } \\
\text { Cl: Confidence interval; OR: Odds ratio;RCT: Randomised controlled trial. }\end{array}$} \\
\hline
\end{tabular}

High certainty: we are very confident that the true effect lies close to that of the estimate of the effect.

Moderate certainty: we are moderately confident in the effect estimate; the true effect is likely to be close to the estimate of the effect, but there is a possibility that it is substantially different.

Low certainty: our confidence in the effect estimate is limited; the true effect may be substantially different from the estimate of the effect.

Very low certainty: we have very little confidence in the effect estimate; the true effect is likely to be substantially different from the estimate of effect.

1 Downgraded 1 level for serious concern for risk of bias.

2 Downgraded 1 level for substantial heterogeneity across and within subgroups.

3 Downgraded 1 level for inconsistencies associated with reporting.

4 Downgraded 1 level - unable to determine precise effects. 


\section{B A C K G R O U N D}

\section{Description of the condition}

Previous estimates suggest that $75 \%$ of women experience at least one episode of vulvovaginal candidiasis (thrush) before the menopause (Sobel 2007). Candidiasis is the term that is used generically for vaginal infections produced by Candida species. Candida albicans (C. albicans) is the species most often associated with candidiasis, however, other yeasts (e.g. C. glabrata, C. krusei) can also cause this infection (Gonçalves 2016).

\section{Description of the intervention}

Vulvovaginal candidiasis is treated with a variety of anti-fungal drugs (Martindale 2017) that are administered by the oral or local (intra-vaginal) route. The decision to use a specific anti-fungal depends upon its safety, effectiveness, cost and patient preference.

\section{How the intervention might work}

There are several classes of anti-fungals with various molecular targets and modes of action (Odds 2003). Therapy for vaginal infection is dominated by the azole class, which includes both oral and intra-vaginal drugs (Pappas 2004). Azoles work by inhibiting the synthesis of fungal lipids, especially ergosterol, which results in damage to the cell membrane leading to cell death (Ghannoum 1999).

\section{Why it is important to do this review}

This review was last updated in 2007. Since then, the pattern of resistance to antifungals could have changed, and as such it is important to identify and include new studies that have been conducted in contemporary populations.

\section{OB JECTIVES}

The primary objective of this review is to assess the relative effectiveness (clinical cure) of oral versus intra-vaginal anti-fungals for the treatment of uncomplicated vulvovaginal candidiasis. Secondary objectives include the assessment of the relative effectiveness in terms of mycological cure, in addition to safety, side effects, treatment preference, time to first relief of symptoms and costs.

\section{METHODS}

\section{Criteria for considering studies for this review}

\section{Types of studies}

We included randomised controlled trials irrespective of publication type or language.

\section{Types of participants}

Women (aged 16 years or over) with uncomplicated vulvovaginal candidiasis. For the purpose of this review, uncomplicated vaginal candidiasis refers to acute episodes of this infection (i.e. less than four episodes in 12 months). The diagnosis of vulvovaginal candidiasis was confirmed mycologically (i.e. a positive culture or microscopy, or both for yeast). Studies were excluded if they solely involved participants who were HIV positive, immunocompromised, pregnant, breast feeding or diabetic. Trials that randomised participants with acute and chronic infections were included if the results for the participants with acute infection were presented separately, or, if less than $20 \%$ of participants had chronic vaginal candidiasis.

\section{Types of interventions}

- Trials that compared any of the imidazole or triazole anti-fungal drugs administered by the intravaginal route (butoconazole, clotrimazole, econazole, fenticonazole, isoconazole, miconazole, omoconazole, oxiconazole, sertaconazole, terconazole, and tioconazole) with orally administered imidazole or triazole anti-fungals (fluconazole, itraconazole).

- Trials that compared more than two anti-fungals were included if they compared oral and intra-vaginal routes of administration, with each two-way comparison (i.e. oral versus intra-vaginal) being treated separately.

We excluded trials that involved ketoconazole (oral and intravaginal) due to its limited licence in many countries.

\section{Types of outcome measures}

\section{Primary outcomes}

- Clinical cure of the infection, both short (5 to 15 days) and long term ( 2 to 12 weeks), as measured by the disappearance of symptoms either on examination or by self-report

\section{Secondary outcomes}

- Mycological cure; both short (5 to 15 days) and long term (2 to 12 weeks) as determined by laboratory test(s) indicating no presence of vulvovaginal candidiasis either by mycological culture or microscopy

- Safety: as measured by the number of patient withdrawals due to adverse reactions

- Side effects: incidence of self-reported adverse reactions (sometimes reported as side effects)

- Treatment preference (of route of administration): measured by self-report

- Time to first relief (of symptoms): measured by self-report

- Costs

\section{Search methods for identification of studies}

\section{Electronic searches}

We searched the following electronic databases on 29 August 2019:

- Cochrane Central Register of Controlled Trials (CENTRAL; 2019, Issue 8) in the Cochrane Library;

- MEDLINE Ovid (including Epub Ahead of Print, In-Process \& Other Non-Indexed Citations and Versions) (1946 onwards);

- Embase Ovid (1974 to 29 August 2019);

Search strategies are comprised of keywords and controlled vocabulary terms. The development of the final search strategy was done with the assistance of Maria Teresa Vallejo, the Information Specialist for the Sexually Transmitted Infections Cochrane Review Group. We included studies regardless of publication type or language of publication. Detailed search strategies are included in Appendix 1. 


\section{Searching other resources}

In addition, we searched WHO ICTRP and ClinicalTrials.gov for ongoing trials. We also handsearched the reference lists of any relevant systematic reviews retrieved via the electronic searches.

\section{Data collection and analysis}

\section{Selection of studies}

For this update, pairs of review authors from HD, JO, JW, MCW and MES independently read all the titles and abstracts retrieved from the electronic searches to identify potentially eligible publications. We retrieved full-text papers for all selected publications. Two review authors from HD, JO, JW, MCW and MES independently assessed their eligibility against the inclusion criteria. We selected studies for the review according to the prespecified inclusion criteria and resolved disagreements by discussion. We collated multiple reports for the same study, so that each study rather than each report is the unit of interest

\section{Data extraction and management}

Two review authors from HD, JO, JW, MCW and MES independently completed data extraction capturing data on the following characteristics and outcomes of each trial:

- the anti-fungal used, dose, frequency and duration of administration;

- type of setting;

- participants;

- outcome measures;

- methodological quality.

\section{Assessment of risk of bias in included studies}

Two review authors from AM, HD, JO, JW and MES independently assessed the risk of bias for each included study using the Cochrane 'Risk of bias' tool as outlined in Chapter 8 of the Cochrane Handbook for Systematic Reviews of Interventions (Higgins 2017). We scored each criterion, for each study, as low risk, unclear risk, or high risk of bias and used the following determinations/consideration when making our judgments for these domains. We resolved any disagreements by discussion.

- Random allocation of treatment: "low risk" if a random process was used (e.g. random numbers), or if the authors stated explicitly that the trial groups were generated by random allocation.

- Allocation concealment: "low risk" if the unit of randomisation was by patient or episode of care, and some form of centralised randomisation scheme was used (e.g. sealed opaque envelopes).

- Blinding of participants and personnel: "low risk" if participants would be blinded to whether they were getting oral or vaginal interventions (e.g. received both treatments with one a placebo).

- Blinding of outcome assessors to participants' assignment status: "low risk" if the authors stated explicitly that the outcome measures were assessed blindly. For clinical outcomes and time to first relief, blinding was reported as "high risk" if the patients could influence the findings by biased reporting. For mycological outcomes, blinding was reported as "low risk" if these were derived from objective tests and not influenced by the patient or assessor.

- Incomplete outcome data: "high risk" if greater than $10 \%$ of participants who were culture positive for yeast were lost to follow-up. The follow-up of the longest duration was used for this assessment.

- Selective reporting: "low risk" if reported the results of all outcomes measured.

- Other potential sources of bias: "low risk" if there were no other sources of bias identified.

\section{Measures of treatment effect}

The primary analysis was a comparison of the relative effectiveness of oral versus intra-vaginal anti-fungals for each outcome described in the Types of outcome measures. We undertook meta-analyses using a fixed-effect model to pool the odds ratios of trials that were homogenous in terms of the outcome measures that were used or that could be calculated. Where it was not possible to undertake a meta-analysis, we report the effects in narrative.

If there were multiple intervention groups in a study, which meant that including all comparisons separately would result in some participants being included in the analysis more than once, we combined the groups to create a single pair-wise comparison as outlined in Chapter 16 of the Cochrane Handbook for Systematic Reviews of Interventions (Higgins 2011).

We calculated odds ratios for the dichotomous outcomes of clinical and mycological cure. In all trials, women were randomised to treatment group (by the investigators) on the basis of their clinical symptoms. At the point of randomisation, a swab was taken for mycological culture. Following randomisation some participants were excluded because they tested negative for candida. To have used the number of participants randomised as the denominator would have underestimated the efficacy of the individual antifungals. Therefore, the denominator used was the number of randomised participants who were culture-positive for yeast prior to receiving an anti-fungal.

We calculated odds ratios for side effects using the number of participants reporting side effects reported in the studies.

The relative safety of both routes of administration was assessed using the number of withdrawals due to adverse drug reactions. We calculated this outcome by assessing whether there were any withdrawals reported in the trials (yes, no, or not reported).

Treatment preference was assessed by recording the number of people that preferred oral treatment versus the number of people that preferred intra-vaginal treatment (and the number of people that had no preference, where relevant) for each study. We then summed the number of trials that found that overall oral treatment was preferred, intra-vaginal was preferred, and no preference.

There was variation in how time to first relief of symptoms was reported in the trials (e.g. mean time, median time, proportion of patients who experienced relief at specific time points), therefore the data could not be combined. We recorded in an additional table the findings from each study that assessed this outcome. 


\section{Unit of analysis issues}

All the included studies were randomised controlled trials with a parallel design. The participants were individually allocated to the treatment or control groups. There were no cross-over or clusterrandomised trials and no unit of analysis issues. We included the per protocol results in the meta-analysis.

\section{Dealing with missing data}

There were little missing data. Where trials had limited or unclear data for an outcome, they were included in the narrative synthesis of results but excluded from meta-analysis.

\section{Assessment of heterogeneity}

We assessed heterogeneity using the $\mathrm{I}^{2}$ statistic, quantifying the percentage of the total variation across studies that is due to heterogeneity rather than chance; smaller percentages suggest less observed heterogeneity (Deeks 2011).

\section{Assessment of reporting biases}

We used funnel plots to assess the likelihood of publication bias.

\section{Data synthesis}

We used the fixed-effect Mantel-Haenszel analysis method to combine outcome data from the trials. Studies that did not have clear numerators or denominators for an outcome were not included in the meta-analysis for that outcome. We provide a descriptive synthesis where data were reported in a form that could not be entered into meta-analysis.

We analysed individual drug comparisons when there were sufficient trials to do so. Comparisons included fluconazole versus clotrimazole, itraconazole versus clotrimazole, fluconazole versus miconazole, fluconazole versus econazole, itraconazole versus econazole, fluconazole versus butoconazole, fluconazole versus fenticonazole, fluconazole versus terconazole, and fluconazole versus sertaconazole. Single-dose anti-fungal regimens were compared as well as single- versus multiple-dose treatment.

\section{Subgroup analysis and investigation of heterogeneity}

We performed several subgroup analyses.

\section{Sensitivity analysis}

Sensitivity analyses were also performed using the methodological quality criteria (see above) and are described in the text. For the sensitivity analyses, methodological quality was assessed using the following criteria and incorporated into the analyses for selection bias, blinding of the outcome assessor and incomplete outcome data.

Selection bias included the assessment for both random allocation and allocation concealment. Random allocation of treatment was considered as "done" if a random process was used (e.g. random numbers), or if the authors stated explicitly that the trial groups were generated by random allocation. Allocation concealment was "done" if the unit of randomisation was by patient or episode of care, and some form of centralised randomisation scheme was used (e.g. sealed opaque envelopes). In order for selection bias to be considered low risk, both random allocation and allocation concealment had to be considered as done. If these criteria were not met, then the study was removed and the analysis repeated only including those studies that met the criteria for selection bias.

Blinding of the outcome assessor was considered "done" if outcome assessors were blinded to participants' assignment status; this was regarded as "done" if the authors stated explicitly that the outcome measures were assessed blindly. If the criteria were not met, then the study was removed and the analysis repeated only including those studies that met the criteria for blinded outcome assessor.

Incomplete outcome data was considered "done" if follow-up in the study at the longest time point was $90 \%$ or greater. If the criteria were not met, then the study was removed and the analysis repeated only including those studies that met the criteria for incomplete outcome data.

\section{Summary of findings}

We graded our confidence in the evidence and summarised the findings in a 'Summary of findings' table using the approach recommended by the GRADE (Grades of Recommendation, Assessment, Development and Evaluation) Working Group (Guyatt 2008). We compared the effectiveness of oral versus intra-vaginal anti-fungals for the treatment of uncomplicated vulvovaginal candidiasis for each of the following important outcomes: clinical cure, mycological cure, safety, side effects, treatment preference, time to first relief of symptoms and costs. We used the five GRADE considerations (study limitations, consistency of effect, imprecision, indirectness, and risk of bias) to assess the certainty of the evidence as it relates the outcomes (Guyatt 2008). We used methods and recommendations described in Section 8.5 and Chapter 12 of the Cochrane Handbook for Systematic Reviews of Interventions (Higgins 2011).

\section{RES U LTS}

\section{Description of studies}

See: Characteristics of included studies

\section{Results of the search}

For this update, we retrieved 792 records from database and registry searches, of which 758 were ineligible. We obtained fulltext articles for the remaining 34 records, seven of which fulfilled the inclusion criteria for this review (ACCELERATE 2002; Coric 2006; Murina 2012; Roongpisuthipong 2010; Sanam 2009; Sekhavat 2011; Škerk V 2006). The total number of trials included in this review is 26 (Figure 1). We identified two systematic reviews to handsearch (Matheson 2017, van Schalkwyk 2016). 
Figure 1. Study flow diagram.

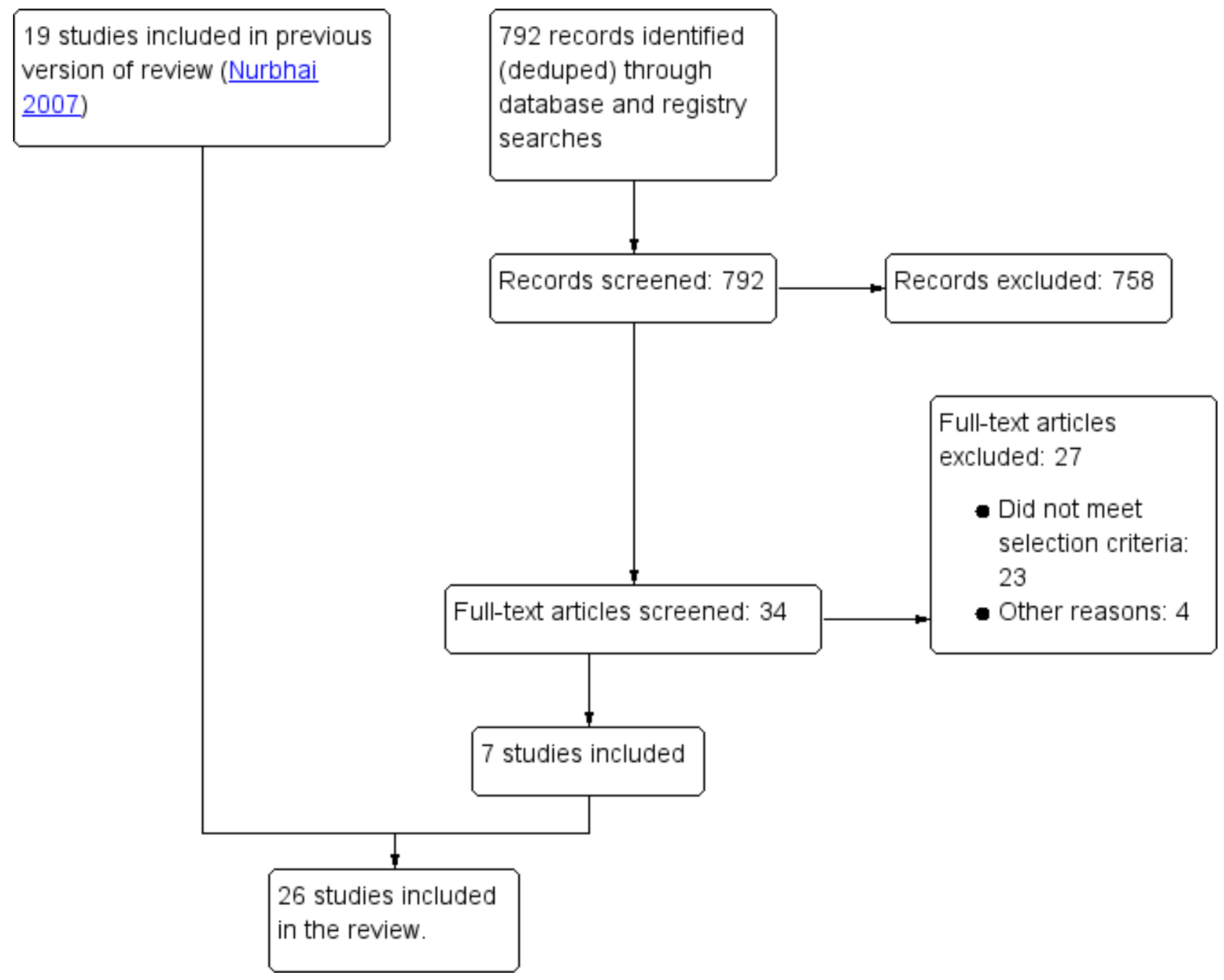

\section{Included studies}

\section{Study design and population}

We included 26 randomised controlled trials involving 5007 women between the ages of 16 and 65 (where reported). Four trials did not report age of the participants (Boag 1991, Coric 2006, Goode 1992, Mendling 2004). One trial stated an age range of 15 to 50 years, however only eight of 188 participants were under 16 years (Roongpisuthipong 2010). One trial presented median age for participants by trial group ( 26 years in one treatment group and 25 years in the other) (Murina 2012).

All of the included studies confirmed the clinical diagnosis of vaginal candidiasis using mycological culture or microscopy, or both. Two trials used microscopy only to provide mycological confirmation of the diagnosis (Slavin 1992; Woolley 1995. There was variation amongst the remaining trials regarding the definition used to confirm the mycological diagnosis. Some trials reported positive "yeast culture" (Boag 1991, Mendling 2004, Osser 1991, Timonen 1992b, Timonen 1992a), whilst others reported positive quote: "culture of Candida species" (Adetoro 1990, Andersen 1989, Mikamo 1995, Mikamo 1995, O-Prasertsawat 1995, Sobel 1995, Stein 1991, Stein 1993, Tobin 1992, Van Heusden 1990, Van Heusden
1994, Woolley 1995). Two trials reported mycological confirmation of "Candidiasis" but did not mention a specific species (Goode 1992, Seidman 2005), and one trial reported quote: "positive $10 \%$ $\mathrm{KOH}$ preparation for budding yeast and/or pseudohypha" $(\mathrm{KOH}=$ potassium hydroxide) (ACCELERATE 2002). The Seidman 2005 trial did not perform yeast cultures. In only one study (Adetoro 1990), was mycological cure defined as the absence of Candida albicans. The terminology most often used in reporting mycological cure was the absence of growth of Candida species.

Twenty-three trials included women with acute vulvovaginal candidiasis; three trials included participants with chronic vulvovaginal candidiasis (Osser 1991, Sobel 1995, Timonen 1992b). In one of these three trials, the results for clinical cure and mycological cure for acute vulvovaginal candidiasis were presented separately from participants with chronic infection, therefore, the results for this trial were generated from the acute participants only for these outcomes (Sobel 1995). Of the 258 participants randomised in the trial by Osser and colleagues, 33 (13\%) had chronic vulvovaginal candidiasis (Osser 1991, and in the trial by Timonen and colleagues,13 (16\%) of the participants had chronic yeast infections. The duration of follow-up varied between trials (see additional Table 1). For the purpose of this review, the 
outcome measures that were presented at between five and 15 days were included in the short-term follow-up comparisons, and the outcome measures that were presented at between two and 12 weeks were included in the long-term follow-up comparisons. Outcome measures that were presented at time points outside these follow-up periods were excluded. There is slight overlap between the duration of short- and long-term follow-up as a result of the trial by Timonen (Timonen 1992b). Ethnicity of the trial populations was not reported in any trial. The trials were published between 1989 (Andersen 1989) and 2012 (Murina 2012).

\section{Setting}

Thirteen trials were conducted in Europe: three in the UK (Boag 1991; Tobin 1992; Woolley 1995); two in Croatia (Coric 2006, Škerk V 2006), Finland (Timonen 1992a; Timonen 1992b) and the Netherlands (Van Heusden 1990 Van Heusden 1994); one each in Germany (Mendling 2004), Italy (Murina 2012), Sweden (Osser 1991); and one trial was conducted across multiple European countries (Andersen 1989). Additionally, seven studies were conducted in the USA, (ACCELERATE 2002,Goode 1992, Seidman 2005, Slavin 1992, Sobel 1995, Stein 1991, Stein 1993); one in Japan (Mikamo 1995); two each in Thailand (O-Prasertsawat 1995, Roongpisuthipong 2010), Iran (Sanam 2009, Sekhavat 2011); and one in Africa/Nigeria (Adetoro 1990). Trials were conducted at both single $(n=10)$ and multi-centred sites $(n=11)$ and five trials did not specify the setting, or were unclear.

\section{Intervention}

In total, eight anti-fungals were represented: two oral treatments; fluconazole and itraconazole,and six intra-vaginal treatments; butoconazole, clotrimazole, econazole, miconazole, sertaconazole and terconazole. Fluconazole was compared with clotrimazole in 15 trials (17 comparisons) (Adetoro 1990; Andersen 1989; Boag 1991;Coric 2006; Goode 1992; Mendling 2004 (two comparisons); Mikamo 1995 (two comparisons); O-Prasertsawat 1995; Roongpisuthipong 2010; Sekhavat 2011; Škerk V 2006; Sobel 1995; Stein 1991; Van Heusden 1994; Woolley 1995); miconazole in three trials (ACCELERATE 2002; Timonen 1992a; Van Heusden 1990), and terconazole (Slavin 1992), econazole (Osser 1991), butoconazole (Seidman 2005), sertaconazole Roongpisuthipong 2010 and fenticonazole (Murina 2012) in one trial each. Itraconazole was compared with clotrimazole in four trials (Sanam 2009; Stein 1993; Tobin 1992; Woolley 1995; and econazole in one trial (Timonen 1992b).

\section{Outcomes}

Thirteen studies reported clinical cure (short term): Coric 2006; Goode 1992; Murina 2012; Osser 1991; Sanam 2009; Seidman 2005; Sekhavat 2011; Sobel 1995; Stein 1991; Stein 1993; Timonen 1992b; Van Heusden 1990; Woolley 1995.

Nine studies reported clinical cure (long term): Goode 1992; Murina 2012; Osser 1991; Škerk V 2006; Sobel 1995; Stein 1991; Stein 1993; Timonen 1992b; Van Heusden 1990.

Twenty studies reported mycological cure (short term): Adetoro 1990; Andersen 1989; Boag 1991; Coric 2006; Goode 1992; Mendling 2004; Mikamo 1995; O-Prasertsawat 1995; Osser 1991; Roongpisuthipong 2010; Sanam 2009; Sekhavat 2011; Sobel 1995; Stein 1991; Stein 1993; Timonen 1992a; Timonen 1992b; Tobin 1992; Van Heusden 1990; Woolley 1995.
Fifteen studies reported mycological cure (long term): Adetoro 1990; Andersen 1989; Goode 1992; Mendling 2004; Mikamo 1995; O-Prasertsawat 1995; Osser 1991; Roongpisuthipong 2010; Sobel 1995; Stein 1991; Stein 1993; Timonen 1992a; Timonen 1992b; Tobin 1992; Van Heusden 1990.

Twenty-three studies reported safety: ACCELERATE 2002; Adetoro 1990; Andersen 1989; Goode 1992; Mendling 2004; Mikamo 1995; Murina 2012; O-Prasertsawat 1995; Osser 1991; Roongpisuthipong 2010; Sanam 2009; Seidman 2005; Sekhavat 2011; Škerk V 2006; Slavin 1992; Sobel 1995; Stein 1991; Stein 1993; Timonen 1992a; Timonen 1992b; Tobin 1992; Van Heusden 1990; Van Heusden 1994

Twenty-two studies reported side effects: ACCELERATE 2002; Adetoro 1990; Andersen 1989; Goode 1992; Mendling 2004; Mikamo 1995; Murina 2012; O-Prasertsawat 1995; Osser 1991; Roongpisuthipong 2010; Sanam 2009; Seidman 2005; Sekhavat 2011; Škerk V 2006; Slavin 1992; Sobel 1995; Stein 1993; Stein 1991; Timonen 1992a;Timonen 1992b; Van Heusden 1990; Van Heusden 1994.

Twelve studies reported treatment preference: Adetoro 1990; Andersen 1989; Coric 2006; Osser 1991; Sekhavat 2011; Slavin 1992; Stein 1993; Timonen 1992b; Timonen 1992a; Tobin 1992; Van Heusden 1990; Van Heusden 1994.

Ten studies reported time to first relief: ACCELERATE 2002; Adetoro 1990; Andersen 1989; Coric 2006; Mendling 2004; Murina 2012; Seidman 2005; Slavin 1992; Timonen 1992a; Tobin 1992.

No studies reported on cost.

\section{Compliance and sources of support}

Compliance checks were undertaken in seven trials (ACCELERATE 2002; Boag 1991; O-Prasertsawat 1995; Osser 1991; Seidman 2005; Slavin 1992; Sobel 1995). One trial reported 99.3\% compliance (ACCELERATE 2002), and one did not report the rate or the numbers of compliance (O-Prasertsawat 1995). The remainder of these trials reported $100 \%$ of participants complied with treatment. Pharmaceutical industry support was reported in 10 trials (ACCELERATE 2002; Adetoro 1990; Andersen 1989; Osser 1991; Roongpisuthipong 2010; Sobel 1995; Stein 1991; Stein 1993; Timonen 1992b; Tobin 1992). We were unable to determine industry support for one trial (Škerk V 2006).

\section{Excluded studies}

We excluded 27 articles at full-text review. Twenty-three of these clearly did not meet the eligibility criteria and were excluded. Four of these studies appeared to meet the eligibility criteria, but while conducting data extraction, we determined that they were not eligible and were subsequently excluded (EUCTR2005-001360-31IT; Fan 2015; Li 2015; Zhou 2016). We have provided an explanation for their exclusion in the Characteristics of excluded studies table along with the five studies excluded in the last published version of the review (Nurbhai 2007).

\section{Risk of bias in included studies}

See: Characteristics of included studies

The risk of bias tables are presented in Figure 2 and Figure 3. 
Figure 2. 'Risk of bias' summary: reviewers judgements about each risk of bias domain for each included study. Blank or empty spaces represent outcomes that were not reported/assessed.

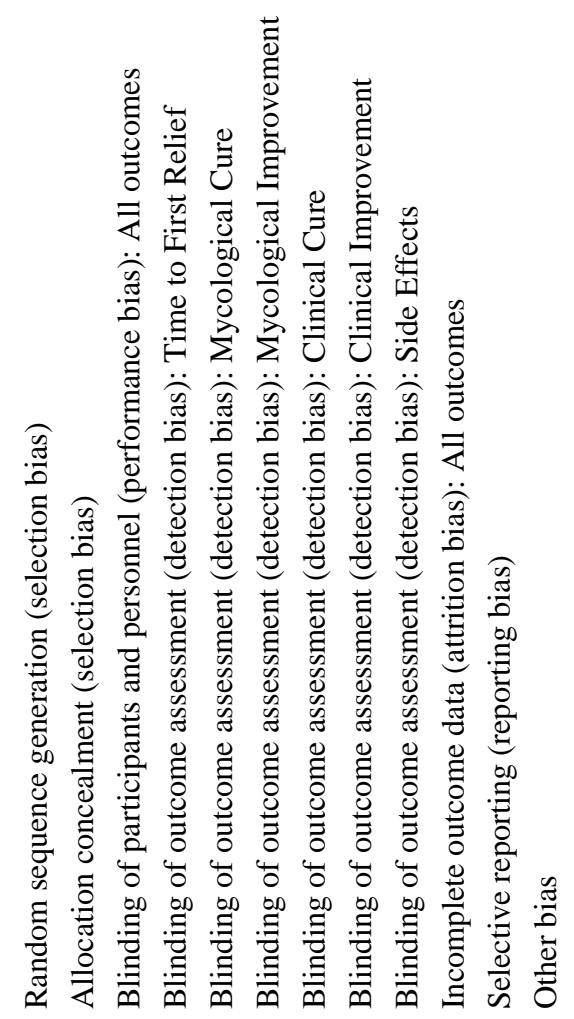

ACCELERATE 2002

Adetoro 1990

Andersen 1989

Boag 1991

Coric 2006

Goode 1992

Mendling 2004

Mikamo 1995

Murina 2012

O-Prasertsawat 1995

Osser 1991

Roongpisuthipong 2010

Sanam 2009

Seidman 2005

Sekhavat 2011

Škerk V 2006

Slavin 1992

Sobel 1995

Stein 1991

Stein 1993

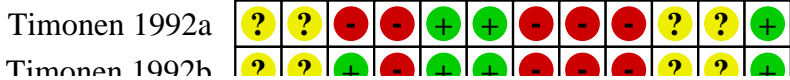

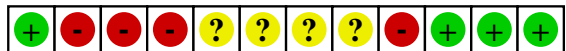

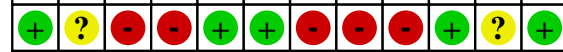

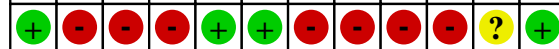

\begin{tabular}{lllllllllllll}
\hline$?$ & $?$ & $\odot$ & $\dagger$ & $\odot$ & $\odot$ & $?$ & ? \\
\hline
\end{tabular}

\begin{tabular}{|lllllllllllll}
\hline$?$ & $?$ & $\odot$ & $\odot$ & + & $\odot$ & $\odot$ & + & $?$ & $?$ \\
\hline
\end{tabular}

?

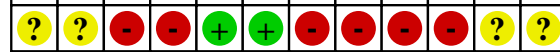

\begin{tabular}{lllllllllllll}
\hline$?$ & $?$ & $\odot$ & $\odot$ & + & $\dagger$ & $\odot$ & $\odot$ & $?$ & $?$ & + \\
\hline
\end{tabular}

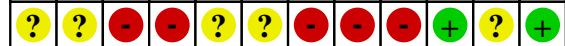

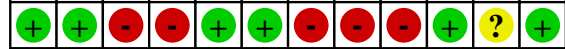

\begin{tabular}{lllllllllllll}
\hline & $?$ & $\odot$ & $\odot$ & + & + & $\odot$ & $\odot$ & $\odot$ & + & $?$ & + \\
\hline
\end{tabular}

\begin{tabular}{llllllllllllll}
\hline & $?$ & $\odot$ & $?$ & + & + & $?$ & $?$ & - & + & $?$ & + \\
\hline
\end{tabular}

\begin{tabular}{llllllllllllll}
\hline$?$ & $?$ & $\odot$ & $\odot$ & + & + & $\odot$ & $\odot$ & $\odot$ & $\uparrow$ & $?$ & $\uparrow$ \\
\hline
\end{tabular}

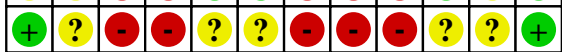

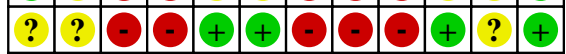

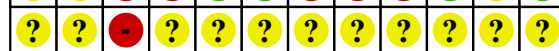

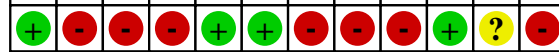

\begin{tabular}{|l|llllllllllllll}
\hline & $?$ & $\odot$ & + & + & $\odot$ & $\odot$ & + & $?$ & + \\
\hline
\end{tabular}

\begin{tabular}{llllllllllllll}
\hline+ & $?$ & - & - & + & + & $\odot$ & $\odot$ & $\odot$ & + & ? & + \\
\hline
\end{tabular}

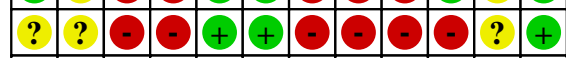


Figure 2. (Continued)

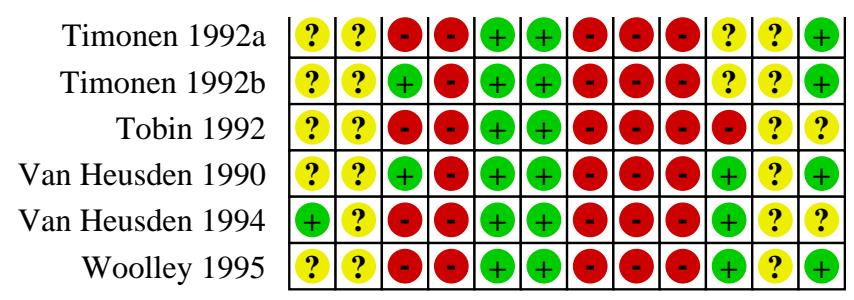

Figure 3. 'Risk of bias' graph: reviewers judgements about each risk of bias domain presented as percentages across all included studies. White spaces in the figure represent outcomes that were not reported/assessed.

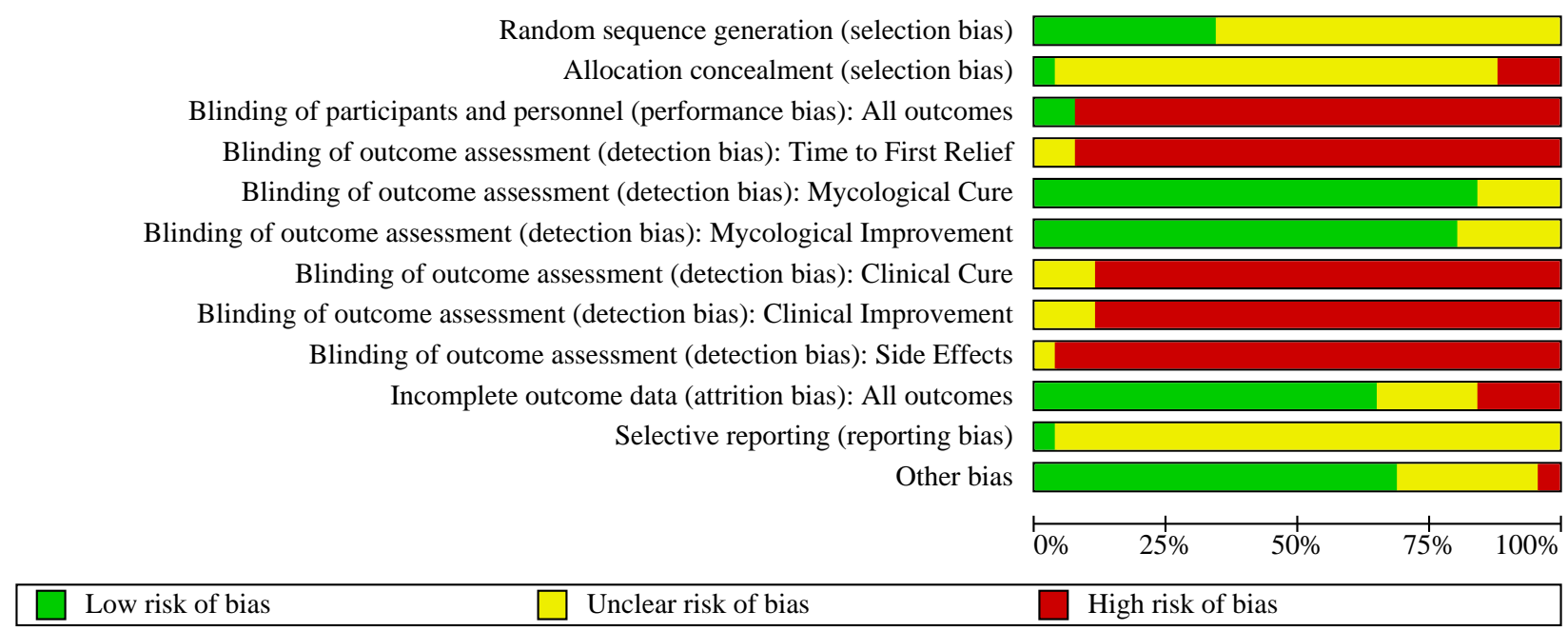

\section{Allocation}

Random sequence generation was adequately described in nine trials (ACCELERATE 2002; Adetoro 1990; Andersen 1989; OPrasertsawat 1995; Roongpisuthipong 2010; Seidman 2005; Slavin 1992; Stein 1991; Van Heusden 1994), and allocation concealment was conducted appropriately in one (O-Prasertsawat 1995). Three trials were at high risk for allocation concealment (ACCELERATE 2002; Andersen 1989; Slavin 1992).

\section{Blinding}

Blinding of participants was graded as high risk for all trials except Timonen 1992b and Van Heusden 1990, as participants would be aware whether they were getting oral or vaginal interventions. For clinical outcomes, blinding was reported as high risk as the patients could influence the findings by biased reporting. Mycological outcomes were reported as low risk because these were derived from objective tests and not influenced by the patient or assessor. Blinding participants would be difficult unless women receiving active intra-vaginal treatment also received an oral placebo and vice versa, with the latter being more problematic.

\section{Incomplete outcome data}

Four trials were at high risk for incomplete outcome data (Andersen 1989; Mendling 2004; Stein 1993; Tobin 1992). In one trial, attrition was greater than $10 \%$ at the second follow-up (27 to 62 days) (Andersen 1989). In the second trial, over $25 \%$ was lost to follow-up in all groups with no explanation provided, though the intention-totreat data were reported (Mendling 2004). The third trial lost $36.8 \%$ of the total number of participants at the second follow-up at four weeks (Stein 1993). Twenty per cent were lost to follow-up in the fourth trial (Tobin 1992).

\section{Selective reporting}

No trials were classified as high risk for selective outcome reporting.

\section{Other potential sources of bias}

Eighteen trials had a low risk of other potential sources of bias and seven had an unclear risk. One trial was categorised as high risk due to baseline imbalances and participants' history of infections (Slavin 1992). 


\section{Effects of interventions}

See: Summary of findings 1 Oral versus intra-vaginal antifungal treatment of uncomplicated vulvovaginal candidiasis

See: Summary of findings 1 for the main comparison.

\section{Oral versus intra-vaginal antifungal treatment of uncomplicated vulvovaginal candidiasis}

\section{Clinical cure}

Fourteen trials reported this outcome. Short-term clinical cure (five to 15 days) was evaluated in 13 trials (Analysis 1.1); and long-term clinical cure (two to 12 weeks) was evaluated in nine trials (Analysis 1.2). There was little or no difference between oral and intra-vaginal anti-fungals for clinical cure at either time point; short term (0dds ratio (OR) $1.14,95 \%$ confidence interval $(\mathrm{Cl}) 0.91$ to $1.43 ; 13$ trials; 1859 participants) and long term (OR $1.07,95 \% \mathrm{Cl} 0.77$ to 1.50 9 trials; 1042 participants). We downgraded the certainty of the evidence for these outcomes to moderate due to serious concern for risk of bias due to lack of blinding of participants and outcome assessors.

The evidence suggests that if the rate of clinical cure at short-term follow-up with intra-vaginal treatment is $77 \%$, the rate with oral treatment would be between $75 \%$ and $83 \%$; if the rate of clinical cure at long-term follow-up with intra-vaginal treatment is $84 \%$, the rate with oral treatment would be between $80 \%$ and $89 \%$.

There was also little or no difference between interventions for any of the subgroup analyses (see subgroups in the data and analysis tables (Analysis 1.1; Analysis 1.2)

One trial, (ACCELERATE 2002) was not included in the single dose versus single dose analyses because, although the participants in the intra-vaginal group were given a single dose of miconazole, they were also provided with miconazole nitrate $(2 \%)$ external vulvar cream to be applied up to twice daily to the vulvar area.

Three studies compared a single dose of oral therapy versus six to seven days intra-vaginal therapy on clinical cure. All three studies had data for short-term follow-up, and the meta-analysis indicated single dose oral therapy probably achieves slightly better clinical cure than six to seven days intra-vaginal therapy (OR 1.57, 95\% Cl 1.03 to $2.42 ; 427$ participants) (Analysis 5.1). Two of these studies had data for long-term follow-up and this effect was not seen in the meta-analysis (OR $0.99,95 \% \mathrm{Cl} 0.54$ to $1.83 ; 266$ participants) (Analysis 5.2). No studies compared single-dose oral therapy versus three-day intra-vaginal therapy on clinical cure.

\section{Mycological cure}

Twenty trials reported short-term mycological cure (Analysis 1.3) and 15 reported long-term mycological cure (Analysis 1.4). Mycological cure was probably improved with oral anti-fungals compared with intra-vaginal anti-fungals; short-term follow-up (OR $1.24,95 \% \mathrm{Cl} 1.03$ to $1.50 ; 19$ trials; 3057 participants) and at long-term follow-up (OR $1.29,95 \% \mathrm{Cl} 1.05$ to $1.60,13$ trials; 1661 participants). We downgraded the certainty of the evidence to moderate due to imprecision of the confidence intervals.

The evidence suggests that if the rate of mycological cure at short -term follow-up with intra-vaginal treatment is $80 \%$, the rate with oral treatment would be between $80 \%$ and $85 \%$; if the rate of mycological cure at long-term follow-up with intra-vaginal treatment is $66 \%$, the rate with oral treatment would be between $67 \%$ and $76 \%$.

We excluded two trials from the meta-analysis. One trial reported long-term mycological response using percentages and we were unable to convert the data to raw numbers (Mendling 2004). We also excluded a second trial due to lack of clarity regarding numbers and definition of cure (Roongpisuthipong 2010).

The clinical significance of this finding is uncertain given that Candida albicans is found routinely in asymptomatic women.

One subgroup analysis (Analysis 1.3.5) (derived from one trial) showed a difference with short-term mycological cure favouring itraconazole compared with econazole (OR 3.55, 95\% Cl 1.29 to $9.77 ; 75$ participants). Two subgroup analyses showed a difference with long-term mycological cure, both of which favoured fluconazole. The first of these analyses (Analysis 1.4.1) comprised seven trials of fluconazole compared with clotrimazole (OR 1.31, $95 \% \mathrm{Cl} 1.00$ to $1.71 ; 1015$ participants), and the second analysis (Analysis 1.4.4) compared fluconazole with econazole (OR 2.17, 95\% $\mathrm{Cl} 1.06$ to $4.42 ; 177$ participants).

There was little or no difference between oral and intra-vaginal antifungals administered as single-dose treatments on mycological cure (single-dose oral anti-fungal therapy versus single -dose intravaginal anti-fungal therapy (Analysis 4.3); single-dose oral therapy versus three-day intra-vaginal therapy (Analysis 3.1, Analysis 3.2); single-dose oral therapy versus six- to seven-day intra-vaginal therapy (Analysis 5.3, Analysis 5.4).

\section{Safety}

Withdrawal due to adverse drug effects was used as a measure of anti-fungal safety. Data from 23 trials (4637 participants) were included in the assessment of this outcome, either because they specifically reported on withdrawals due to adverse events, or they reported data which indicated there were either no side effects or minor side effects only (no adverse events). Of these 23 trials, three reported withdrawals (Analysis 1.5). One trial reported that one participant discontinued the miconazole treatment because of a severe burning sensation in the vagina (Timonen 1992a); a second trial reported one withdrawal from fluconazole due to diarrhoea (Stein 1991), and a third trial reported a withdrawal from the miconazole group due to severe vulvovaginal burning (ACCELERATE 2002). No withdrawals due to adverse drug reactions were reported in any other trial. We did not downgrade the certainty of the evidence as we did not have any major concerns for each quality domain. Given that the overall number of withdrawals were low, there was low risk of withdrawal due to adverse drug effects for either treatment.

\section{Side effects}

Twenty-two trials (4423 participants) evaluated side effects (ACCELERATE 2002; Adetoro 1990; Andersen 1989; Goode 1992; Mendling 2004; Mikamo 1995; Murina 2012; O-Prasertsawat 1995; , Roongpisuthipong 2010; Sanam 2009; Seidman 2005; Sekhavat 2011; Škerk V 2006; Slavin 1992; Sobel 1995; Stein 1993; Stein 1991; Timonen 1992a;Timonen 1992b; Van Heusden 1990; Van Heusden 1994). We were unable to include six trials in the metaanalysis. Two trials did not provide numerical data about sideeffect events, indicating that side effects were minimal (Goode 
1992; Roongpisuthipong 2010). A further three trials reported no side effects events for either treatment group, so these trials were not included in the meta-analysis as they did not provide any indication of the direction or magnitude of the relative treatment effect (Mikamo 1995; Škerk V 2006; Slavin 1992). Lastly, Van Heusden 1994 was not included in the estimates because a denominator was unclear.

It is undetermined whether oral treatments reduced the number of side effects compared with intra-vaginal treatments (OR 1.04, 95\% $\mathrm{Cl} 0.84$ to 1.29 ; 16 trials; 3155 participants; low-certainty evidence). The evidence suggests that if the rate of side effects with intravaginal treatment is $12 \%$, the rate with oral treatment would be between $10 \%$ and $15 \%$.

Anti-fungals administered intra-vaginally were more often associated with local reactions (e.g. irritation, "burning", pruritus) than with those administered by the oral route, but systemic effects were also reported (i.e. headache). The oral route of administration was associated with a wide range of systemic effects including gastro-intestinal side effects and headache.

We downgraded the certainty of the evidence to low due to high risk of bias and substantial heterogeneity across and within subgroups. The outcome was self-reported, and trials used different thresholds for side effects, i.e. some reported all adverse events occurring during the evaluation period and some reported only adverse events that were specifically related to the treatment.

Due to the certainty of evidence being low, we are uncertain whether oral treatments reduced the number of side effects compared with intra-vaginal treatments (Analysis 1.6, Analysis 2.5, Analysis 5.5).

\section{Treatment preference}

Twelve trials (2206 participants) reported a preference for the route of anti-fungal administration (Adetoro 1990; Andersen 1989; Coric 2006; Osser 1991; Sekhavat 2011; Slavin 1992; Stein 1993; Timonen 1992b; Timonen 1992a; Tobin 1992; Van Heusden 1990; Van Heusden 1994) (Analysis 1.7). These data were poorly reported. Two trials made statements about treatment preference but no quantitative data were presented (Adetoro 1990; Stein 1993). The inconsistencies associated with reporting the preferred route of administration limit the use of these data. Almost all trials that reported patient preference favoured oral treatment (compared with intra-vaginal or no preference), with proportions ranging from $52 \%$ of women favouring oral treatment in the trial by Van Heusden (Van Heusden 1994), to 93\% in the Timonen trial (Timonen 1992a). The trial by Tobin 1992 provided data on whether participants preferred the study treatment to previous treatments received, with a higher proportion of the oral treatment group responding affirmatively compared to the intra-vaginal treatment group, however it was not reported whether previous treatments were oral or vaginal. We downgraded the certainty of the evidence to low due to the high risk of bias shown in the trials and inconsistencies with reporting the preferred route of administration.

\section{Time to first relief of symptoms}

Ten trials (1910 participants) evaluated time to first relief (ACCELERATE 2002; Adetoro 1990; Andersen 1989; Coric 2006, Mendling 2004; Murina 2012; Seidman 2005; Slavin 1992; Timonen 1992a; Tobin 1992). There was little or no difference in time to first relief of symptoms between oral and intra-vaginal treatments. Four trials favoured the oral treatment, four favoured intra-vaginal, one study reported no difference and one was unclear. There was considerable variation in the methods used to derive this outcome and as such, no direct comparisons can be made (Analysis 1.8). There was also variation in the way the data were reported. For example, five trials reported the median time to first relief (ACCELERATE 2002; Andersen 1989; Mendling 2004; Seidman 2005; Slavin 1992), three trials reported the mean time to first relief (Murina 2012; Slavin 1992; Tobin 1992), and four trials reported the proportion of patients reporting initial relief at certain time points (e.g. 12 hours, 24 hours) (ACCELERATE 2002; Coric 2006; Seidman 2005; Timonen 1992a). No specific data were reported for this outcome by Adetoro 1990. We downgraded the certainty of the evidence to low due to high risk of bias for blinding and imprecision due to self-report.

\section{Cost}

None of the included trials reported cost or economic data. No trial reported the relative cost-effectiveness of the two modes of treatment (oral and intra-vaginal).

\section{Sensitivity Analyses}

Sensitivity analyses are reported in Table 2. Four main outcomes were considered; short- and long-term clinical cure and short- and long-term mycological cure. In all of the analyses for selection bias or blinded outcome assessor, there were either no comparisons or one comparison which made any comparison to the full sample of studies difficult.

In the analyses for incomplete outcome data, there was a sufficient number of studies classified as low risk of bias to compare to the whole sample for the four outcomes. All four of the sensitivity analyses had odds ratios that fell within the confidence intervals of the odds ratios for the same outcome including all the studies, suggesting that the difference between the odds ratio for the sensitivity analyses was similar to the odds ratio for the entire sample.

\section{Other analyses}

\section{Publication bias}

Based on our searches of trial registers, we did not identify any relevant and completed trials that remained unpublished. Through the database searches, we found one trial that was published as a conference abstract only. This trial looked at secondary outcomes of safety, side effects, and time to first relief (ACCELERATE 2002). We were able to obtain the full details of the trial from the author and the manufacturer. The funnel plots were fairly symmetrical (Figure 4; Figure 5; Figure 6; Figure 7; Figure 8). 
Figure 4. Funnel plot of comparison: 1 Oral vs Intra-vaginal, outcome: 1.1 Clinical cure (short term).

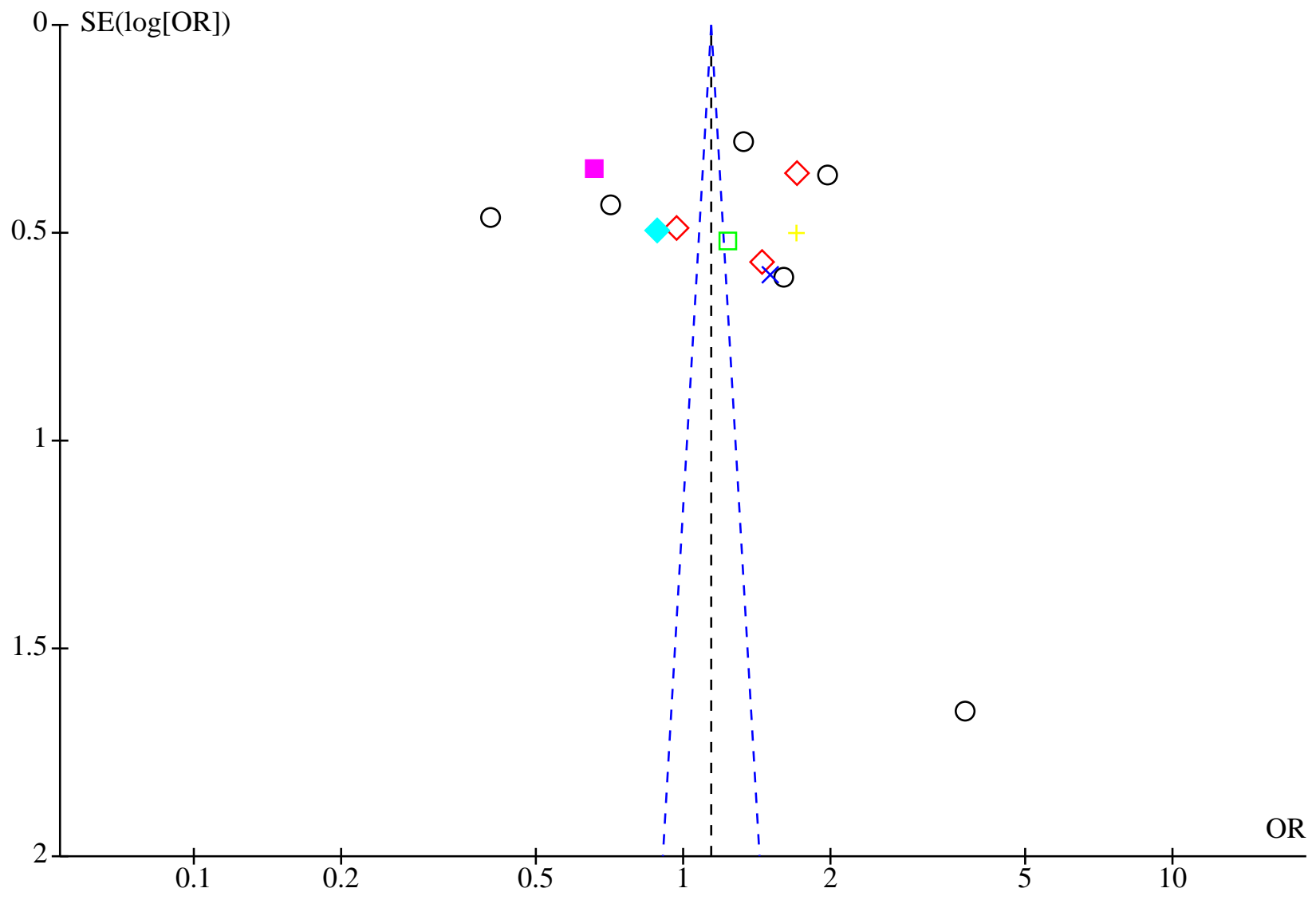

\section{Subgroups}

Fluconazole vs Clotrimazole

Itraconazole vs Econazole

$\diamond$ Itraconazole vs Clotrimazole

Fluconazole vs Butoconazole

Fluconazole vs Miconazole

Fluconazole vs Fenticonazole

$\times$ Fluconazole vs Econazole 
Figure 5. Funnel plot of comparison: 1 Oral vs Intra-vaginal, outcome: 1.2 Clinical cure (long term).

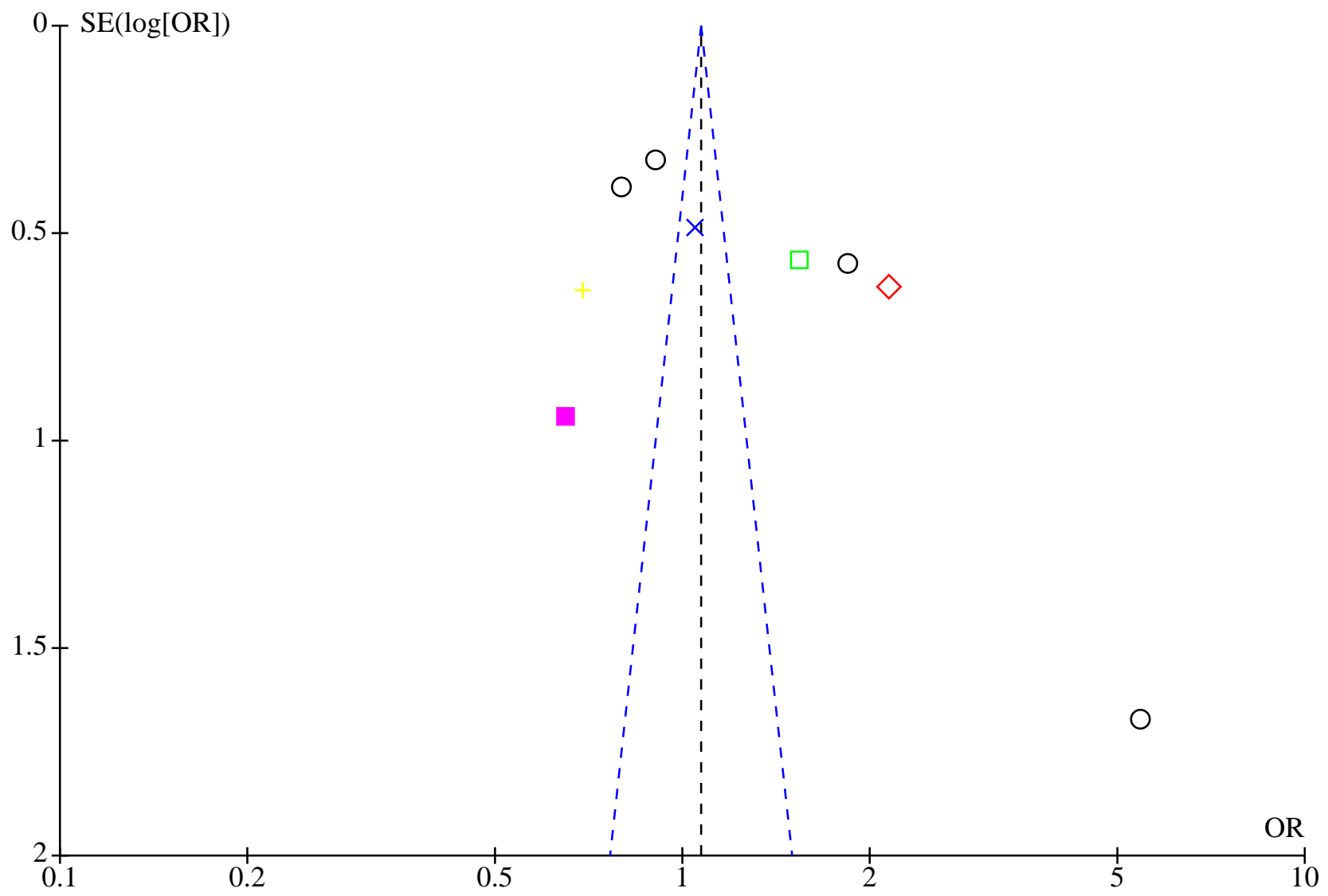

\section{Subgroups}

$\bigcirc$ Fluconazole vs Clotrimzole

$\times$ Fluconazole vs Econazole

$>$ Itraconazole vs Clotrimazole

Itraconazole vs Econazole

Fluconazole vs Miconazole

Fluconazole vs Fenticonazole 
Figure 6. Funnel plot of comparison: 1 Oral vs Intra-vaginal, outcome: 1.3 Mycological cure (short term).

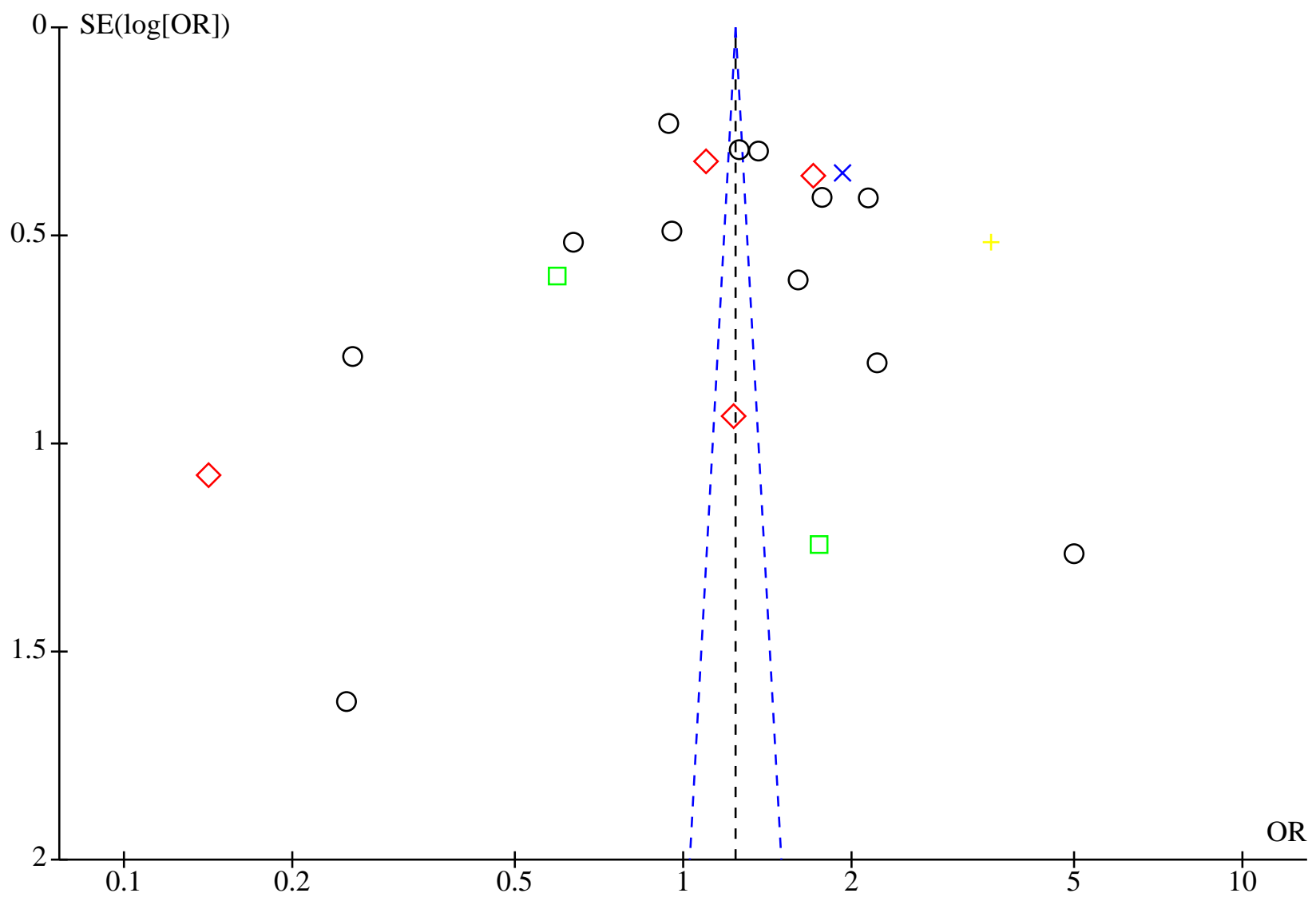

\section{Subgroups}

Fluconazole vs Clotrimazole

$\times$ Fluconazole vs Econazole

Itraconazole vs Clotrimazole

Itraconazole vs Econazole

Fluconazole vs Miconazole 
Figure 7. Funnel plot of comparison: 1 Oral vs Intra-vaginal, outcome: 1.4 Mycological cure (long term).

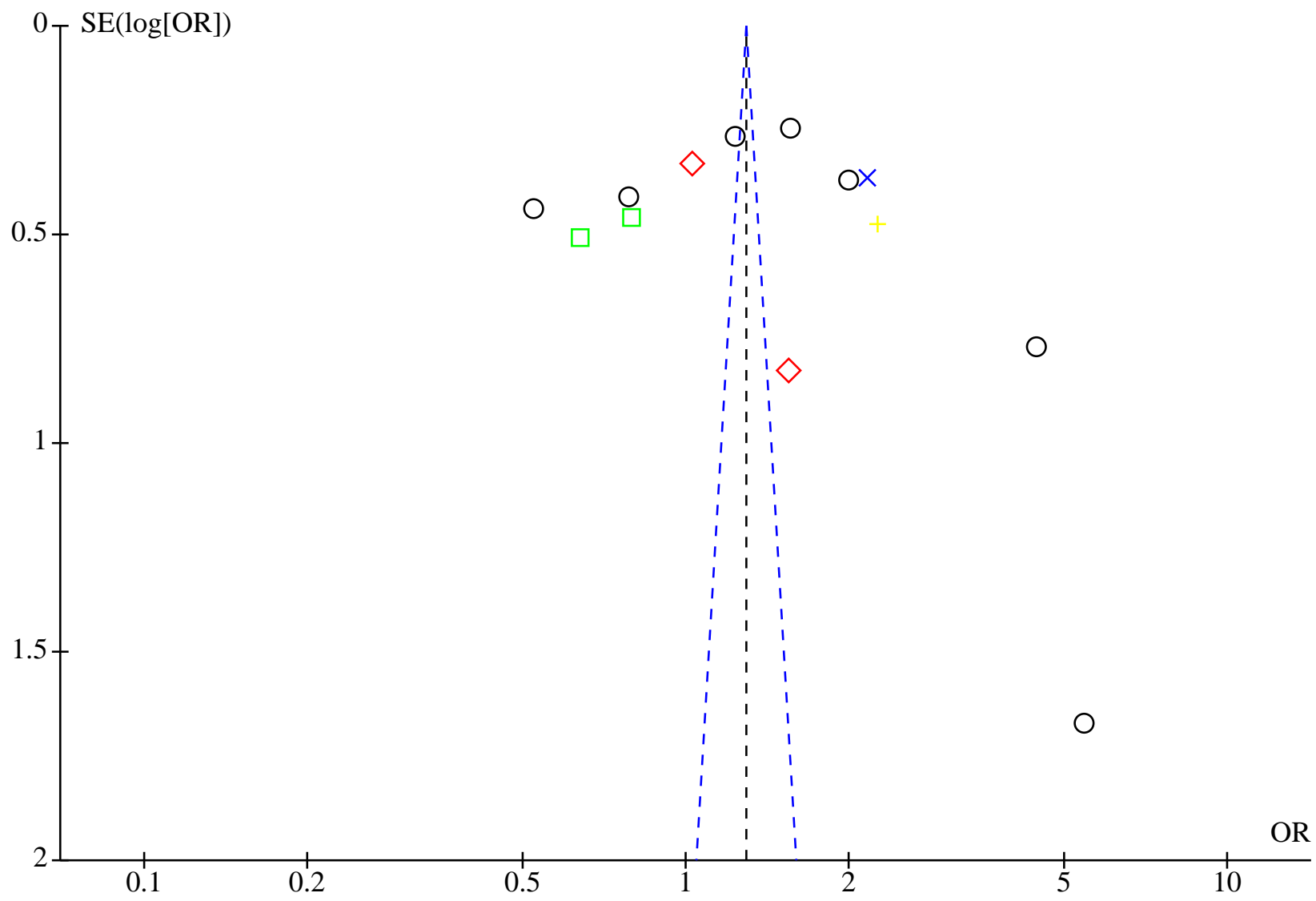

Subgroups

Fluconazole vs Clotrimazole

$\times$ Fluconazole vs Econazole

$>$ Itraconazole vs Clotrimazole

Itraconazole vs Econazole

Fluconazole vs Miconazole 
Figure 8. Funnel plot of comparison: 1 Oral vs Intra-vaginal, outcome: 1.6 Side effects.

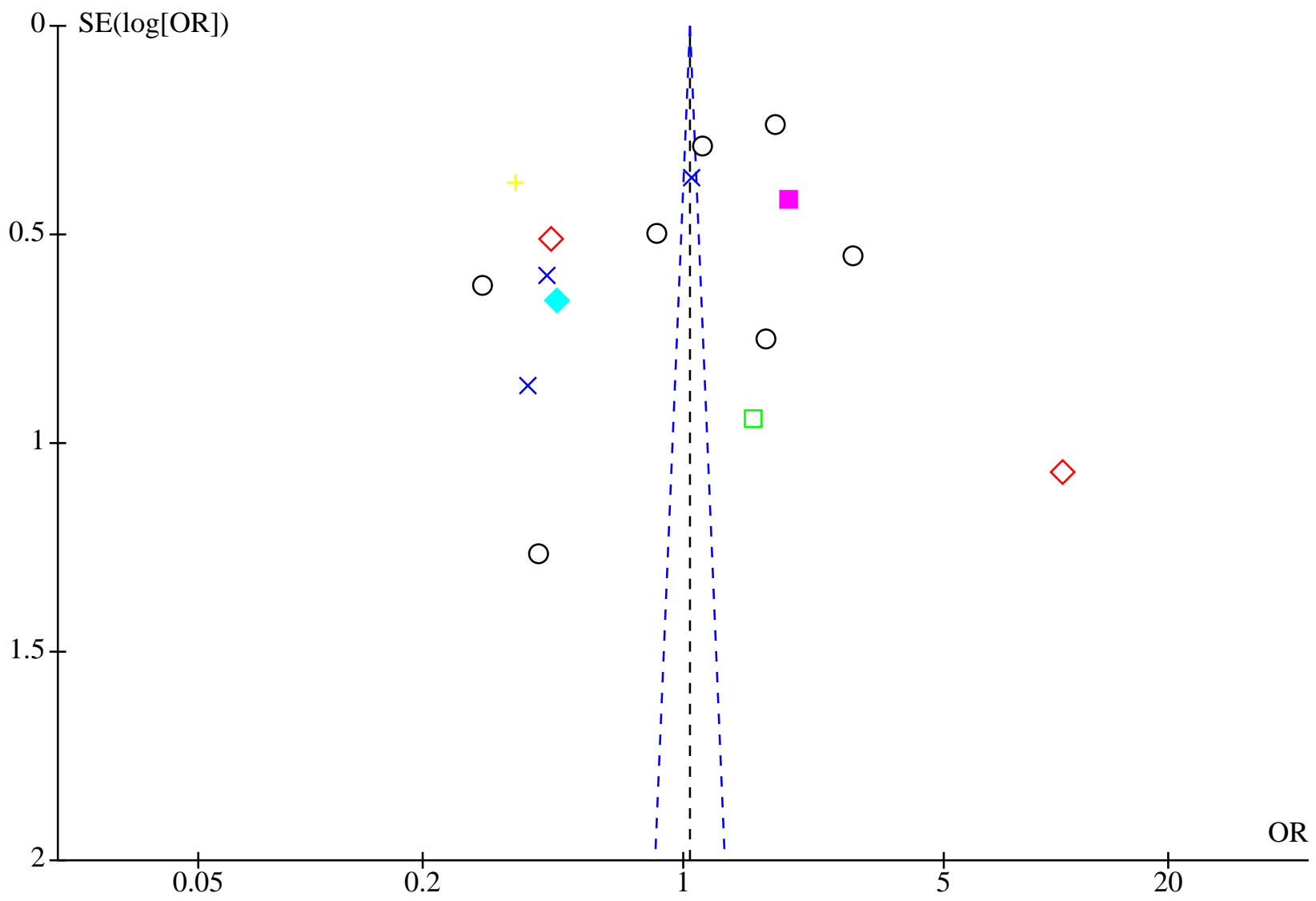

\section{Subgroups}

Fluconazole vs Clotrimazole

Itraconazole vs Clotrimazole

Fluconazole vs Fenticonazole

Fluconazole vs Econazole

Fluconazole vs Butoconazole

$\times$ Fluconazole vs Miconazole

Itraconazole vs Econazole

\section{DISCUSSION}

\section{Summary of main results}

This review compared the relative effectiveness and safety of oral versus intra-vaginal anti-fungals for the treatment of uncomplicated vulvovaginal candidiasis. We identified 26 trials published between 1989 and 2012 that examined the effectiveness of eight anti-fungals: two oral treatments (fluconazole and itraconazole), and six intra-vaginal treatments (butoconazole, clotrimazole, econazole, miconazole, sertaconazole and terconazole).

There was probably little or no difference between oral and intravaginal antifungals for short- and long-term clinical cure. Both routes of administration achieved clinical cure in over $70 \%$ of participants. Similar proportions were observed with short-term mycological cure. Our confidence in the evidence is moderate, and this research provides a good indication of the likely effect.
Six trials reported compliance checks. It is possible that noncompliance could have contributed to therapeutic failure (clinical and/or mycological) with some participants.

It is possible that the proportion of women who did not experience clinical cure following anti-fungal therapy (approximately $20 \%$ of participants participating in the trials included in this review), had vaginitis due to other causes. Most trials excluded participants with concomitant vaginal infections (e.g. chlamydia, Trichomonas). It is possible that some participants may have had an undiagnosed urogenital infection or condition which, in addition to their fungal infection, contributed to their clinical symptoms. Other factors may have influenced unresponsive women's symptoms, including chemical irritants (e.g. perfumed products, detergents) and physical damage (e.g. due to tampons, sexual intercourse).

Oral treatment probably improves mycological cure in the shortand long-term follow-up over intra-vaginal treatment. While our confidence in the evidence is moderate, and this research provides a good indication of the likely effect, the short-term cure rate of 
$83 \%$ and $80 \%$ for oral and intra-vaginal preparations, respectively, requires consideration, i.e. what were the causes of therapeutic failure in approximately $20 \%$ of women treated? Therapeutic failure may have been due to the presence of fungal species outside the spectrum of the anti-fungals used, or, resistance to specific anti-fungals. The prevalence of non-albicans species has increased rapidly in recent years (Spinillo 1997). Non-albicans Candida species are associated with vaginitis but these organisms are more resistant to conventional anti-fungal therapy (Sobel 1993). There is evidence that $C$. glabrata and $C$. krusei are resistant to fluconazole and itraconazole (Rex 2000).

The decrease in mycological cure at long-term follow-up may be explained to some extent by the re-growth of normal Candida species as part of the vaginal flora. The higher long-term clinical cure rates support this theory (i.e. the number of women who were mycologically cured decreased between short- and longterm follow-up, however, a corresponding reduction in clinical cure for these time points was not shown). Other factors may contribute to the reduction in mycological cure. Women may have been exposed to risk factors associated with vaginal candidiasis following their entry into a study. Fluctuations in hormone balance (e.g. menstruation, contraceptive use), drug use (e.g. antibiotics, corticosteroids), and changes in hygiene, diet or sexual behaviour, may result in Candidal colonisation (Reed 1992, Sobel 1993, Anonymous 1999). Undiagnosed diabetes may also be a contributory factor to recurrent infection (Anonymous 1999).

There was probably little or no difference between single-dose oral anti-fungal treatment and multiple-dose intra-vaginal regimens. This contrasts with the results of a review of the treatment of vaginal candidiasis in pregnancy that showed multiple dose treatment to be more effective than single-dose anti-fungal therapy (Young 2001).

Withdrawal due to adverse drug effects was used as a measure of anti-fungal safety. There was a low risk of withdrawals due to adverse drug effects for either treatment. Three of 22 studies reported one withdrawal each: two from the intra-vaginal group and one from the oral treatment group. While having few withdrawals appears to demonstrate a low risk, we are not sure which treatment has less risk. The certainty of the evidence was high.

There was little or no difference between treatments in terms of side effects. The certainty of the evidence is low and it is possible that with additional research, the effects could change. Intuitively, the oral administration of any drug, anti-fungal or otherwise, is more likely to be associated with a greater proportion of adverse drug reactions than the intra-vaginal administration of a drug from the same therapeutic category. Furthermore, adverse reactions resulting from anti-fungals given systemically may be more severe or have more serious consequences than those occurring with intra-vaginal administration.

Patient treatment preference for route of anti-fungal administration was assessed as a secondary outcome measure. Data for this outcome were poorly reported and our confidence in the evidence is low. The majority of trials which included this outcome presented percentages of participants who preferred oral treatment and percentages who preferred intra-vaginal treatment, but the denominator was often not reported, and neither were data on whether participants had previous experience of oral and/ or intra-vaginal anti-fungal therapy. Despite this shortcoming, the oral route was consistently the preferred route of administration for anti-fungals in trials included in this review. It should be bourne in mind, however, that oral preparations are usually more expensive than intra-vaginal treatments and the systemic side effects associated with oral treatment are likely to be of a more serious nature than intra-vaginal anti-fungals.

We found that there was little or no difference that oral treatments were faster than intra-vaginal treatments for symptom relief (time to first relief) as reported by participants. There was considerable variation in the methods used to derive this outcome and in the way the data were reported. As the certainty of the evidence is low, it is possible that with future research this effect could change.

We were unable to determine the impact of oral versus intravaginal treatment on costs. Few data were present in the included trials that could be used in a cost-effectiveness analysis. Generally, oral anti-fungal treatment is more expensive than intra-vaginal therapies. Whether it is the woman or her health system who pays for her anti-fungal treatment will have implications in terms of the difference in costs between the two options for route of administration.

\section{Overall completeness and applicability of evidence}

A variety of anti-fungals are available worldwide for the treatment of this infection. In some countries, these drugs can be purchased without a prescription enabling customers to self-medicate. Our search strategies included all the generic names of identifiable anti-fungals that are available world-wide and which are licensed for the treatment of uncomplicated vulvovaginal candidiasis. We identified 26 trials published between 1989 and 2012 that examined the effectiveness of eight anti-fungals (two oral treatments; fluconazole and itraconazole,and six intra-vaginal treatments; butoconazole, clotrimazole, econazole, miconazole, sertaconazole and terconazole). All but three trials included participants with acute vulvovaginal candidiasis. Trials were conducted mainly in high-income countries. The duration of follow-up varied between trials. We were able to identify one unpublished trial through the searches (ACCELERATE 2002). Despite contacting the manufacturers of anti-fungal preparations in the UK for the original review (Nurbhai 2007), we did not locate any others and did not contact manufacturers for this update. We did not limit the search strategies to English language publications, reducing the risk of publication bias (Egger 1997a,Egger 1997b, Moher 1996).

Trials either used a defined range of age limits for their inclusion criteria, were open ended, or did not specify the ages of the participants, thus it was difficult to get a clear picture of the full range of ages of the participants from the trials. One trial stated an age range of 15 to 50 years (Roongpisuthipong 2010). While this age range was outside our pre-specified inclusion criteria (16 years or over), we included this trial in our analyses because only eight participants were in the 15 to 19 year age range. Two additional trials included in our analysis had a lower age limit of 15 years old in their age criteria, however the participants were all aged 16 years and over ( Adetoro 1990; Osser 1991). Lastly, four trials did not report the age of participants (Boag 1991, Coric 2006, Goode 1992, Mendling 2004), and one only presented median age for participants by trial group ( 26 years in one treatment group and 25 years in the other) (Murina 2012). 
We did not include trials of oral ketoconazole or intra-vaginal ketoconazole in this review due to previous concerns regarding its safety profile. This drug is available in some countries for the treatment of vaginal candidiasis, however, it was not included in this review. The authors of future updates of this review might wish to consider the inclusion of trials of intra-vaginal formulations of ketoconazole.

\section{Quality of the evidence}

We identified 26 randomised controlled trials involving 5007 women between the ages of 15 and 65 (where reported). Twentythree trials included women with acute vulvovaginal candidiasis and three trials included women with chronic vulvovaginal candidiasis. There were eight anti-fungals studied: two oral treatments and six intra-vaginal treatments.

The certainty of the evidence ranged from low to high. The main reason for downgrading was due to serious concern with regards to risk of bias followed by substantial heterogeneity across and within subgroups. There were inconsistencies associated with reporting and we were unable to determine precise effects for some outcomes.

Overall, the risk of bias of the included trials was high. Allocation concealment was poorly reported in all but one trial. Outcome assessment was not blinded in many trials and may have resulted in performance bias in terms of clinical cure. However, all women received active treatment which suggests that this should have been balanced between groups and might not necessarily represent a form of bias unless there was an interaction between treatment preference and treatment received. The denominator could not be calculated for a number of trials because of the poor reporting of data.

Pharmaceutical industry support was reported in 10 trials. It is possible that of the remaining trials, some also had pharmaceutical industry involvement that was not reported. Pharmaceutical sponsorship may be associated with publication bias in randomised trials of drug comparisons (Rochon 1994).

\section{Potential biases in the review process}

Using the denominator based upon the number of participants randomised instead of those who were mycologically positive for yeast altered the findings of the review: no statistically significant differences were shown between oral and intra-vaginal treatments when this denominator was used. It should be borne in mind that using the former denominator may overestimate the antifungal effect because a proportion of women randomised on the basis of their clinical symptoms will have a negative yeast culture. Using the number of women who had a positive yeast culture as the denominator will underestimate the number of women experiencing clinical cure if recruitment and randomisation has been performed on the basis of these clinical symptoms.

\section{Agreements and disagreements with other studies or reviews}

A total of 41 RCTs were included in a recent Bayesian network metaanalysis of the efficacy of anti-fungal medicines for the treatment of vaginal candidiasis (Qin 2018). Seven of the antifungals tested were shown to be more effective than placebo and of these, fluconazole was deemed to be most effective. This study also included studies of ketoconazole as well as non-azole antifungals, and did not restrict comparisons to oral versus intra-vaginal.

\section{AUTHORS' CONCLUSIONS}

\section{Implications for practice}

There is little or no difference between oral and intra-vaginal anti-fungals in terms of clinical cure. Oral antifungal treatment achieved slightly higher mycological cure rates than intra-vaginal administration of these agents. The decision to prescribe or recommend the purchase of an anti-fungal for oral or intra-vaginal administration should take into consideration: cost, treatment preference, and contraindications.

Unless there is a previous history of adverse reaction to one route of administration or contraindications, women who are purchasing their own treatment should be given full information about the characteristics and costs of treatment to make their own decision. If health services are paying the treatment cost, decision-makers should weigh up the higher cost of oral anti-fungal administration with the marginal gain in mycological cure.

\section{Implications for research}

It is questionable whether further trials need to be conducted comparing oral and intra-vaginal anti-fungals. If further trials are conducted, however, they need to incorporate measures of methodological quality specified in this review, robust methods of assessing and reporting treatment preference, and, full health economic assessments of the treatment options under investigation. Further trials need to address outcomes that are useful to the patients for example time to first relief of symptoms (Seidman 2005), adverse events and patient preferences.

Adequate methods of allocation concealment should be used to avoid bias (Schulz 1995).

\section{ACK N O WLEDGEMEN TS}

The authors thank Ana Marcela Torres and the Information Specialists of the Cochrane STI Group and Liz Dooley for her technical assistance. We are grateful to Adrienne Stevens who assisted with screening the results for this update. The authors also thank Sheila Wallace of the Cochrane Collaboration Incontinence Group for her advice regarding search strategies for earlier versions of the review. We also thank Ms Margaret Ross for performing reference retrieval for the original review. The authors would also like to thank Ahmed Alamry, Munira Nurbhai, Jill A Mollison and Anne Ludbrook of the Cochrane Effective Practice and Organisation of Care Group for their assistance with the earlier work of this review. A special thanks to Jenny Osaikhuwuomwan (JO), who made a major contribution to the initial start of this update in 2015, including study selection, data abstraction, risk of bias and GRADE assessment and also contributed to the early review manuscripts. 


\section{RE F E R E N C E S}

\section{References to studies included in this review}

ACCELERATE 2002 \{published and unpublished data\}

* Multicenter USA . Clinical Study Report MONISTAT@ -1 (OVULETM) Combination pack versus fluconazole: a clinical evaluation of time to symptomatic relief of vaginal yeast infections. Personal Products Company, Division of McNeil-PPC, Inc. CLINICAL STUDY REPORT DOCUMENT NO. CA-R-2411.

Williams NS, Phillips N, Bachmann G. Oral compared with local antifungal treatment of yeast infection: Comparison of time to symptomatic relief. In: Obstetrics and Gynecology. Conference: 63rd Annual Clinical and Scientific Meeting of the American College of Obstetricians and Gynecologists San Francisco, CA United States.. Conference Start 2015;125:2015.

\section{Adetoro 1990 \{published data only\}}

Adetoro 00. Comparative trial of a single dose of fluconazole $(150 \mathrm{mg})$ and a single intravaginal tablet of clotrimazole $(500 \mathrm{mg})$ in the treatment of vaginal candidiasis. Current Therapeutic Research 1990;48(2):275-81.

\section{Andersen 1989 \{published data only\}}

* Andersen GM, Barrat J, Bergan T, Brammer KW, Cohen J, Dcllenbach $\mathrm{P}$, et al. A comparison of single-dose oral fluconazole with 3-day intravaginal clotrimazole in the treatment of vaginal candidiasis. British Journal of Obstetrics and Gynaecology 1989;96:226-32.

Brammer KW, Lees LJ. Single dose oral fluconazole in the treatment of vulvovaginal candidiasis: an interim analysis of a comparative study versus three-day intravaginal clotrimazole tablets. In: Fromtling RA, editors(s). Recent Trends in the Discovery, Development and Evaluation of Antifungal Agents. Vol. n/a. South Africa: University of Michigan, 1987:151-6.

Lassus A. A comparative study of fluconazole and clotrimazole. Royal Society of Medicine Services International Congress and Symposium Series No. 160 1989;not specified:37-9.

\section{Boag 1991 \{published data only\}}

Boag FC, Houang ET, Westrom R, McCormack SM, Lawrence AG. Comparison of vaginal flora after treatment with a clotrimazole $500 \mathrm{mg}$ vaginal pessary or a fluconazole $150 \mathrm{mg}$ capsule for vaginal candidosis. Genitourinary Medicine 1991;67:232-4.

Coric 2006 \{published data only\}

Coric M, Barisic D, Lovric H. Fluconazole versus 3-day clotrimazole in the treatment of sporadic and recurrent vulvovaginal candidiasis. International Journal of Gynecology and Obstetrics 2006;95:171-2.

\section{Goode 1992 \{published data only\}}

Goode MA, Karig AW, Carson DS, Hamadeh G. Single dose fluconazole versus clotrimazole in the treatment of vaginal candidiasis. In: International Pharmaceutical Abstracts (ASHP Midyear Clinical Meeting 27:SPG-61. December 1992.
Mendling 2004 \{published data only\}

Mendling W, Krauss C, Fladung B. A clinical multicenter study comparing efficacy and tolerability of topical combination therapy with clotrimazole (Canesten, two formats) with oral single dose fluconazole (Diflucan) in vulvovaginal mycoses. Mycoses 2004;47:136-42.

\section{Mikamo 1995 \{published data only\}}

Mikamo H, Izumi K, Ito K, Tamaya T. Comparative study of the effectiveness of oral fluconazole and intravaginal clotrimazole in the treatment of vaginal candidiasis. Infectious Diseases in Obstetrics and Gynaecology 1995;3:7-11.

\section{Murina 2012 \{published data only\}}

Murina F, Grazziottin A, Felice R, Di Francesco S, Mantegazza V. Short course treatment of acute vulvovaginal candidiasis: comparative study between fluconazole and intravaginal fenticonazole [Il trattamento "short course" della candidosivulvovaginale acuta: studio comparativotra il fluconazolo ed il fenticonazolo intravaginale]. Minerva Medica 2011;63:1-2.

\section{O-Prasertsawat 1995 \{published data only\}}

O-Prasertsawat P, Bourlert A. Comparative study of fluconazole and clotrimazole for the treatment of vulvovaginal candidiasis. Sexually Transmitted Diseases 1995;22(4):228-30.

\section{Osser 1991 \{published data only\}}

* Osser S, Haglund A, Westrom L. Treatment of candidal vaginitis. A prospective randomized investigator-blind multicenter study comparing topically applied econazole with oral fluconazole. Acta Obstetricia Gynaecologie Scandinavia 1991;70:73-8.

Westrom L, Haglund A, Svensson L. Fluconazole versus econazole in treating vaginal candidiasis. International Journal of Gynaecology and Obstetrics 1992;37(Supplement):29-31.

\section{Roongpisuthipong 2010 \{published data only\}}

Roongpisuthipong A, Chalermchockcharoenkita A, Sirimaia K, Wanitpongpana P, Jaishuena A, Foongladdab S, et al. Safety and efficacy of a new imidazole fungicide, Sertaconazole, in the treatment of fungal vulvo-vaginitis:a comparative study using Fluconazole and Clotrimazole. Asian Biomedicine 2010;4(3):443-8.

\section{Sanam 2009 \{published data only\}}

Sanam M. Comparison of the efficacy of Clotrimazole and Itraconazole in the treatment of acute vulvovaginal candidiasis. Journal of the Bahrain Medical Society 2009;21(3):294-7.

\section{Seidman 2005 \{published data only\}}

Seidman LS, Skokos CK. An evaluation of butoconazole nitrate $2 \%$ Site Release vaginal cream (Gynazole-1) compared to fluconazole $150 \mathrm{mg}$ tablets (Diflucan) in the time to relief of symptoms in patients with vulvovaginal candidiasis. Infectious Diseases in Obstetrics and Gynecology 2005;13(4):197-206. 
Sekhavat 2011 \{published data only\}

Sekhavat L, Tabatabaii A, Tezerjani FZ. Oral fluconazole $150 \mathrm{mg}$ single dose versus intra-vaginal clotrimazole treatment of acute vulvovaginal candidiasis. Journal of Infection and Public Health 2011;4:195-9.

\section{Škerk V 2006 \{published data only\}}

Škerk V, Jakšić J, Žarković T, Škalko D, Begovac J. Postmarketing research of the efficacy and tolerability of fluconazole and clotrimazole in the treatment of vulvovaginal Candidiasis [Postmarketinško ispitivanje djelotvornosti i podnošljivosti liječenja vulvovaginalne kandidoze flukonazolom i klotrimazolom]. Croatian Journal of Infection 2006;26(3):135-7.

Slavin 1992 \{published data only\}

Slavin MB, Benrubi GI, Parker R, Griffin CR, Magee MJ. Single dose oral fluconazole vs intravaginal terconazole in treatment of candida vaginitis. Journal of Florida Medical Association 1992;79(10):693-6.

\section{Sobel 1995 \{published data only\}}

Sobel JD, Brooker D, Stein GE, Thomason JL, Wermeling DP, Bradley B, et al. Single oral dose fluconazole compared with conventional clotrimazole topical therapy of Candida vaginitis. American Journal of Obstetrics and Gynaecology 1995;172:1263-8.

\section{Stein 1991 \{published data only\}}

Stein GE, Christensen S, Mummaw N. Comparative study of fluconazole and clotrimazole in the treatment of vulvovaginal candidiasis. DICP: the Annals of Pharmacotherapy 1991;25:582-5.

\section{Stein 1993 \{published data only\}}

Stein GE, Mummaw N. Placebo-controlled trial of itraconazole for treatment of acute vaginal candidiasis. Antimicrobial Agents and Chemotherapy 1993;37(1):89-92.

\section{Timonen 1992a \{published data only\}}

Timonen H, Fluconazole Study Group. Shorter treatment for vaginal candidosis: comparison between single-dose oral fluconazole and three-day treatment with local miconazole. Mycoses 1992;35:317-20.

\section{Timonen 1992b \{published data only\}}

Timonen H, Hartikainen-Vahtera P, Kivijarvi A, Kohtamaki K, Kosunen $\mathrm{M}$, Lehtonen $\mathrm{L}$, et al. A double-blind comparison of the effectiveness of itraconazole oral capsules with econazole vaginal capsules in the treatment of vaginal candidosis. Drug Investigation 1992;4(6):515-520.

\section{Tobin 1992 \{published data only\}}

Tobin JM, Loo P, Granger SE. Treatment of vaginal candidosis: a comparative study of the efficacy and acceptability of itraconazole and clotrimazole. Genitourinary Medicine 1992;68:36-8.

\section{Van Heusden 1990 \{published data only\}}

Van Heusden AM, Merkus HM, Corbeij RS, Oosterbaan HP, Stoot JE, Ubachs HM, et al. Single-dose oral fluconazole versus single-dose topical miconazole for the treatment of acute vulvovaginal candidosis. Acta Obstetricia Gynaecologie Scandinavia 1990;69:417-22.

\section{Van Heusden 1994 \{published data only\}}

Van Heusden AM, Merkus HM, Euser R, Verhoeff A. A randomized, comparative study of a single oral dose of fluconazole versus a single topical dose of clotrimazole in the treatment of vaginal candidosis among general practitioners and gynaecologists. European Journal of Obstetrics and Gynaecology and Reproductive Biology 1994;55:123-7.

Woolley 1995 \{published data only\}

Woolley PD. Comparison of clotrimazole, fluconazole and itraconazole in vaginal candidiasis. British Journal of Clinical Practice 1995;49(2):65-6.

\section{References to studies excluded from this review \\ EUCTR2005-001360-31-IT \{unpublished data only\}}

EUCTR2005-001360-31-IT. A multicenter, randomised, doubleblind, between-patient, dose finding study to assess the safety, tolerability and efficacy of three different dosages $(500,1000$ and $2000 \mathrm{mcg} / \mathrm{g}$ ) of ABIO 12/01 gel, in comparison to an open active treatment, after a five-day vaginal administration to females with a confirmed clinical diagnosis of vulvovaginal candidiasis. https://www.clinicaltrialsregister.eu/ctr-search/ search?query=eudract_number:2005-001360-31.

\section{Fan 2015 \{published data only\}}

Fan S, Liu X, Liang Y. Miconazole nitrate vaginal suppository $1,200 \mathrm{mg}$ versus oral fluconazole $150 \mathrm{mg}$ in treating severe vulvovaginal candidiasis. Gynecologic and Obstetric Investigation 2015;80(2):113-8.

Fong 1992 \{published data only\}

Fong IW. The value of chronic suppressive therapy with itraconazole versus clotrimazole in women with recurrent vagianl candidiasis. Genitourinary Medicine 1992;68:374-7.

Herzog 1989 \{published data only\}

Herzog RE, Ansmann EB. Treatment of vaginal candidosis with fluconazole. Mycoses 1989;32(4):204-8.

\section{Li 2015 \{published data only\}}

Li T, Zhu Y, Fan S, Liu X, Liang. A randomized clinical trial of the efficacy and safety of terconazole vaginal suppository versusoral fluconazole for treating severe vulvovaginal candidiasis. Medical mycology 2015, June;53(5):455-61.

Lopez Olmos 1994 \{published data only\}

Lopez Olmos J, Parra, I. Vaginal candidiasis treatment: Prospective comparative study of three commercial products with a single dose. Clinica e Investigacion en Ginecologia y Obstetricia 1994;21(7):300-6. [AN 94291310]

\section{Mikamo 1998 \{published data only\}}

Mikamo H, Kawazoe K, Sato Y, Hayasaki Y, Tamaya T. Comparative study on the effectiveness of antifungal agents in different regimens against vaginal candidiasis. Chemotherapy 1998;34:364-8. 
Wermeling 1992 \{published data only\}

Wermeling DP, McCraney SA. Single dose oral fluconazole versus miconazole vaginal cream in the treatment of vaginal candidiasis. International Pharmaceutical Abstracts (ASHP Midyear Clinical Meeting 27:SPG-61 (Dec) 1992) 1992;n/s:196.

\section{Zhou 2016 \{published data only\}}

Zhou X, Li T, Fan S, Zhu Y, Liu X, Guo X et al. The efficacy and safety of clotrimazole vaginal tablet vs. oral fluconazole in treating severe vulvovaginal candidiasis. Mycoses 2016;59(7):419-282016.

\section{Additional references}

\section{Anonymous 1999}

Clinical Effectiveness Group (Association of Genitourinary Medicine and the Medical Society for the Study of Venereal Diseases). National guideline for the management of vulvovaginal candidiasis. Sexually Transmitted Infections 1999;75(Supplement 1):S19-S20.

\section{Deeks 2011}

Deeks JJ, Higgins JP, Altman DG. Chapter 9: Analysing data and undertaking meta-analyses. In: Higgins JP, Green S (editors). Cochrane Handbook for Systematic Reviews of Interventions Version 5.1.0 (updated March 2011). The Cochrane Collaboration, 2011. Available from handbook.cochrane.org.

\section{Egger 1997a}

Egger M, Zellweger-Zahner T, Schneider M, Junker C, Lengeler C, Antes $G$. Language bias in randomised controlled trials published in English and German. Lancet 1997;350:326-9.

\section{Egger 1997b}

Egger M, Davey Smith G, Schneider M, Minder C. Bias in meta-analysis detected by a simple, graphical test. $B M J$ 1997;315:629-34.

\section{Ghannoum 1999}

Ghannoum MA, Rice LB. Antifungal agents: mode of action, mechanisms of resistance, and correlation of these mechanisms with bacterial resistance. Clinical Microbiology Reviews 1999;12(4):501-17. [PMID: 10515900 ]

\section{Gonçalves 2016}

Gonçalves B, Ferreira C, Alves CT, Henriques M, Azeredo J, Silva S. Vulvovaginal candidiasis: Epidemiology, microbiology and risk factors. Critical Reviews in Microbiology 2016;42:905-27.

\section{Guyatt 2008}

Guyatt GH, Oxman AD, Vist GE, Kunz R, Falck-Ytter Y, AlonsoCoello P et al, GRADE Working Group. An emerging consensus on rating quality of evidence and strength of recommendations. BMJ 2008;336(7650):924-6.

\section{Higgins 2011}

Higgins JP, Green S, editor(s). Cochrane Handbook for Systematic Reviews of Interventions Version 5.1.0 (updated March 2011). The Cochrane Collaboration, 2011. Available from handbook.cochrane.org.

\section{Higgins 2017}

Higgins JP, Altman DG, Sterne JA, editor(s). Chapter 8: Assessing risk of bias in included studies. In: Higgins JP, Churchill R, Chandler J, Cumpston MS, editor(s), Cochrane Handbook for Systematic Reviews of Interventions version 5.2.0 (updated June 2017). The Cochrane Collaboration, 2017. Available from www.training.cochrane.org/handbook.

\section{Martindale 2017}

Brayfield A. Martindale: The complete drug reference. Thirtyninth edition. London: Pharmaceutical Press, 2017.

\section{Matheson 2017}

Matheson A, Mazza D. Recurrent vulvovaginal candidiasis: a review of guideline recommendations. Australian and New Zealand Journal of Obstetrics and Gynaecology 2017;57(2):139-45.

\section{Moher 1996}

Moher D, Fortin P, Jada AR, Juni P, Klassen T, Le Lorier J, et al. Completeness of reporting of trials published in languages other than English: implications for conduct and reporting of systematic reviews. Lancet 1996;347:363-6.

\section{Odds 2003}

Odds FC, Brown AJ, Gow NA. Antifungal agents: mechanisms of action. Trends in Microbiology 2003;11(6):272-9. [DOI: 10.1016/ s0966-842x(03)00117-3]

\section{Pappas 2004}

Pappas PG, Rex JH, Sobel JD, Filler SG, Dismukes WE, Walsh TJ, et al. Guidelines for treatment of Candidiasis. Clinical Infectious Diseases 2004;38(2):161-89.

\section{Qin 2018}

Qin F, Wang Q, Zhang C, Fang C, Zhang L, Chen H, et al. Efficacy of antifungal drugs in the treatment of vulvovaginal candidiasis: a Bayesian network meta-analysis. Infection and Drug Resistance 2018;11:1893-901.

\section{Reed 1992}

Reed RD. Risk factors for Candida Vulvovaginitis. Obstetrical and Gynecological Survey 1992;47(8):551-60.

\section{$\operatorname{Rex} 2000$}

Rex JH, Walsh TJ, Sobel JD, Filler SG, Pappas PG, Dismukes WE, et al. Practice guidelines for the treatment of candidiasis. Clinical Infectious Diseases 2000;30:662-78.

\section{Rochon 1994}

Rochon PA, Gurwitz JH, Simms RW. A study of manufacturersupported trials of nonsteroidal anti-inflammatory drugs in the treatment of arthritis. Archives of Internal Medicine 1994;154:157-63.

\section{Schulz 1995}

Schulz KF. Subverting randomization in controlled trials. JAMA 1995;274:1456-8. 


\section{Sobel 1993}

Sobel JD. Candidal vulvovaginitis. Clinical Obstetrics and Gynaecology 1993;36(1):153-65.

\section{Sobel 2007}

Sobel JD. Vulvovaginal candidosis. Lancet 2007;369(9577):1961-71.

\section{Spinillo 1997}

Spinillo A, Capuzzo E, Gulminetti R, Marone P, Colonna L, Piazzi G. Prevalence and risk factors for fungal vaginitis caused by non-albicans species. American Journal of Obstetrics and Gynaecology 1997;176(1):138-41.

\section{van Schalkwyk 2016}

van Schalkwyk J, Yudin MH. Vulvovaginite: Dépistage et prise en charge de la trichomonase, de la candidose vulvovaginale et de la vaginose bactérienne. Journal of Obstetrics and Gynaecology Canada 2016;38(12):S587-S596.

\section{Young 2001}

Young GL, Jewell D. Topical treatment for vaginal candidiasis (thrush) in pregnancy. Cochrane Database of Systematic Reviews 2001, Issue 4. Art. No: CD000225. [DOI: 10.1002/14651858.CD000225]

\section{CHARACTERISTICS OF STUDIES}

Characteristics of included studies [ordered by study ID]

\section{References to other published versions of this review} Nurbhai 2007

Nurbhai M, Grimshaw J, Watson M, Bond CM, Mollison JA, Ludbrook A. Oral versus intra-vaginal imidazole and triazole anti-fungal treatment of uncomplicated vulvovaginal candidiasis (thrush). Cochrane Database of Systematic Reviews 2007, Issue Issue 4. Art. No: CD002845. [DOI: 10.1002/14651858.CD002845.pub2]

\section{Watson 2000}

Watson MC, Grimshaw JM, Bond CM, Mollison J, Ludbrook A. Oral versus local anti-fungal treatment of acute uncomplicated vulvovaginal candidiasis. Cochrane Database of Systematic Reviews 2000, Issue Issue 4. Art. No: CD002845. [DOI: 10.1002/14651858.CD002845]

\section{Watson 2001}

Watson MC, Grimshaw JM, Bond CM, Mollison J, Ludbrook A. Oral versus intra-vaginal imidazole and triazole anti-fungal treatment of uncomplicated vulvovaginal candidiasis (thrush). Cochrane Database of Systematic Reviews 2001, Issue Issue 3. Art. No: CD002845. [DOI: 10.1002/14651858.CD002845]

* Indicates the major publication for the study

\section{ACCELERATE 2002}

\section{Study characteristics}

Methods Study design: randomised trial (multi-centre)

Follow-up: $91.3 \%$ completed study, $82.9 \%$ included in efficacy evaluable sample

Age: 18 years or older
Country: USA
Setting: 24 centres (Obstetic/Gyncology OPD)
Diagnosis: vulvovaginal candidiasis by positive $10 \%$ potassium hydroxide wet preparation
Characteristics: non-pregnant, non-nursing, with negative wet mount for trichomonas and clue cells
and total vulvovaginal signs/symptoms score of 4 or more.
Enrolled: 310 (305 evaluable)

Interventions

Group 1: fluconazole oral $150 \mathrm{mg}$ (single dose $(n=150)$;

Group 2: miconazole nitrate, $1200 \mathrm{mg}$ vaginal suppository plus external vulvar $2 \%$ cream (Monistat@ combination pack) single dose $(n=160)$

Duration: 11 April to 23 October 2002

\section{Outcomes}

Assessed at: 2, 4, 6, 12, 16, 24, 36, 48, 60, and 72 hours following first administration of the MONISTAT External Cream and/or OVULE Insert, or ingestion of the oral tablet. Follow-up: posttherapy telephone contact approximately seven to 10 days following.

\section{Efficacy}

Oral versus intra-vaginal imidazole and triazole anti-fungal treatment of uncomplicated vulvovaginal candidiasis (thrush) (Review) 
ACCELERATE 2002 (Continued)

Mycological cure: not reported

Mycological improvement: not reported

Clinical cure: not reported

Safety: reported

Quote:"one subject (04506) was withdrawn for a clinically significant adverse event".

Side effects: reported

Drug 1: 17 (11.4\%) participants reported at least one treatment-emergent adverse event during the study

Drug 2: 17 (10.9\%) participants reported at least one treatment-emergent adverse event during the study

Treatment preference: not assessed

Time to first relief: reported.

Time to first relief: (itching, burning, irritation) self-report using diary/worksheet. Based on change in total symptom scores. Primary efficacy parameter was to be the first recorded time of symptom relief, defined as the length of time between the first dose of study drug and the time first relief was noted OR the length of time between the first dose of study drug and the time first relief was noted on the diary. The time to overall symptom relief was to be based on the maximum time to relief of any of the symptoms of itching, burning, or irritation.

Other: change in symptom score from baseline, consumer satisfaction (Consumer Satisfaction Questionnaire) adverse events (stated - preferred form of therapy)

Costs: not assessed

Notes

Compliance check: yes. At the Posttherapy Telephone Contacts (seven to 10 days following the first dose of study medication), the use of the study medication was confirmed.

A total of 303 (99.3\%)participants in the safety population were considered compliant

Pharmaceutical industry support: study sponsored by Personal Products Company

\section{Risk of bias}

\begin{tabular}{lll}
\hline Bias & Authors' judgement & Support for judgement \\
\hline $\begin{array}{l}\text { Random sequence genera- } \\
\text { tion (selection bias) }\end{array}$ & Low risk & $\begin{array}{l}\text { Quote: "randomization sequence provided by Personal Products Company } \\
\text { (PPC)" }\end{array}$ \\
$\begin{array}{ll}\text { Quote: "Eligible subjects were to be equally randomized in strict sequential or- } \\
\text { der to one of two treatment regimens according to a randomization schedule } \\
\text { generated by PPC. There was no blinding in this study." }\end{array}$ \\
$\begin{array}{ll}\text { Allocation concealment } \\
\text { (selection bias) }\end{array}$ & High risk & No description of allocation concealment. \\
\hline $\begin{array}{l}\text { Blinding of participants } \\
\text { and personnel (perfor- } \\
\text { mance bias) } \\
\text { All outcomes }\end{array}$ & High risk & Quote: "There was no blinding in this study" \\
\hline
\end{tabular}

Blinding of outcome as- High risk sessment (detection bias) 
ACCELERATE 2002 (Continued)

Time to First Relief

Blinding of outcome as-
sessment (detection bias) $\quad$ Unclear risk Outcome not assessed.

sessment (detection bias)

Mycological Cure

$\begin{array}{ll}\text { Blinding of outcome as- } & \text { Unclear risk }\end{array}$

Mycological Improvement

Blinding of outcome as-
sessment (detection bias) $\quad$ Unclear risk Outcome not assessed.

Clinical Cure

\begin{tabular}{|c|c|c|}
\hline $\begin{array}{l}\text { Blinding of outcome as- } \\
\text { sessment (detection bias) } \\
\text { Clinical Improvement }\end{array}$ & Unclear risk & Outcome not assessed \\
\hline
\end{tabular}

\begin{tabular}{ll}
\hline Blinding of outcome as- & High risk $\quad$ Quote: "There was no blinding in this study". \\
sessment (detection bias) &
\end{tabular}

Side Effects

Incomplete outcome data Low risk Less than $10 \%$ lost to follow-up and close in both groups.
(attrition bias)

(attrition bias)

All outcomes

\begin{tabular}{lll}
\hline $\begin{array}{l}\text { Selective reporting (re- } \\
\text { porting bias) }\end{array}$ & Low risk & Protocol available, see section 7.2 in protocol, page 111. \\
\hline Other bias & Low risk & None identified, no baseline imbalance. \\
\hline
\end{tabular}

\section{Adetoro 1990}

\section{Study characteristics}

\begin{tabular}{ll}
\hline Methods & Study design: randomised trial \\
& Follow-up: $100 \%$ \\
\hline Participants & Age: $17-30$ years old \\
Country: Africa/Nigeria \\
Setting: Gynaecological and "special treatment" clinics at the University of Ilorin Teaching Hospital \\
Diagnosis: mycological culture, positive microscopic smear and clinical symptoms. \\
Characteristics: non-lactating \\
Enrolled: 43
\end{tabular}

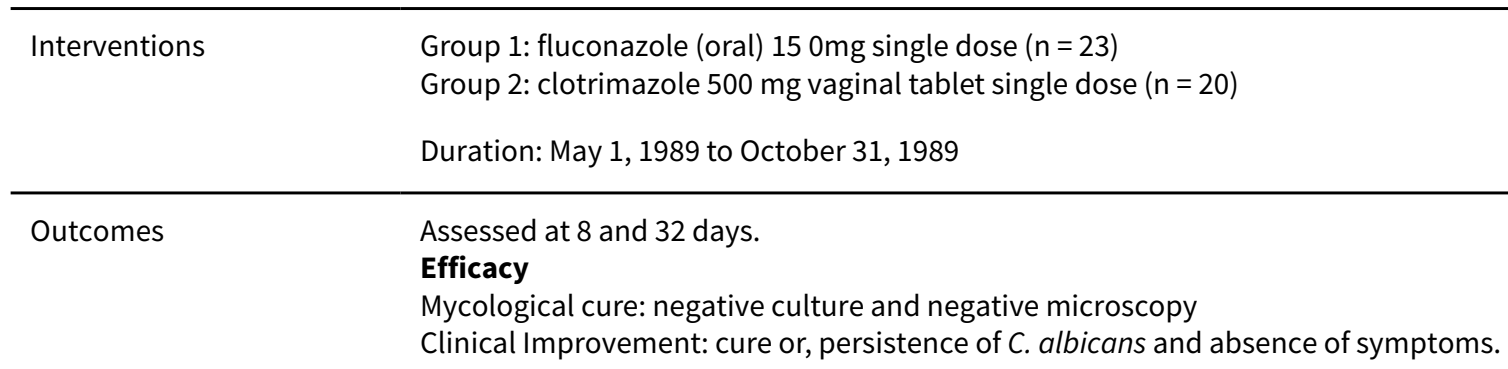


Safety: no withdrawals due to side effects reported

Side effects: number of side effects reported.

Treatment preference: reported

Time to first relief: assessed, but no specific data reported

Costs: not assessed

Compliance checks: not specified
Pharmaceutical industry support: yes: Pfizer Products Limited
The results do not distinguish between clinical and mycological cure
Actual participant numbers not presented for mycological outcome - only percentage values given.
This trial had a lower age limit of 15 years old in their age criteria, however the participants were all
aged 16 years and over.

Risk of bias

\begin{tabular}{lll}
\hline Bias & Authors' judgement & Support for judgement \\
\hline $\begin{array}{l}\text { Random sequence genera- } \\
\text { tion (selection bias) }\end{array}$ & Low risk & Predetermined randomisation code, probably random. \\
\hline $\begin{array}{l}\text { Allocation concealment } \\
\text { (selection bias) }\end{array}$ & Unclear risk & No description provided. \\
\hline $\begin{array}{l}\text { Blinding of participants } \\
\begin{array}{l}\text { and personnel (perfor- } \\
\text { mance bias) }\end{array}\end{array}$ & High risk & Not possible given nature of intervention. \\
All outcomes & \\
\hline
\end{tabular}

\begin{tabular}{lll}
$\begin{array}{l}\text { Blinding of outcome as- } \\
\text { sessment (detection bias) } \\
\text { Time to First Relief }\end{array}$ & High risk & Not possible given nature of intervention, and self-report. \\
\hline $\begin{array}{l}\text { Blinding of outcome as- } \\
\text { sessment (detection bias) } \\
\text { Mycological Cure }\end{array}$ & Low risk & $\begin{array}{l}\text { Testing done by lab cultures, which are objective outcomes, not influenced by } \\
\text { blinding. }\end{array}$ \\
\hline $\begin{array}{l}\text { Blinding of outcome as- } \\
\text { sessment (detection bias) } \\
\text { Mycological Improvement }\end{array}$ & Low risk & $\begin{array}{l}\text { Testing done by lab cultures, which are objective outcomes, not influenced by } \\
\text { blinding. }\end{array}$ \\
\hline
\end{tabular}

Blinding of outcome as- High risk Not possible given nature of intervention, and subjective outcome.

sessment (detection bias)

Clinical Cure

$\begin{array}{lll}\begin{array}{l}\text { Blinding of outcome as- } \\ \text { sessment (detection bias) }\end{array} & \text { High risk } & \begin{array}{l}\text { Not possible to avoid risk given nature of intervention, and subjective out- } \\ \text { come. }\end{array}\end{array}$

Clinical Improvement

$\begin{array}{lll}\text { Blinding of outcome as- } & \text { High risk } & \text { Not possible to avoid risk given nature of intervention, and subjective out- } \\ \text { sessment (detection bias) } & & \text { come. }\end{array}$

Side Effects

Incomplete outcome data Low risk No losses to follow-up, all participants completed study.
(attrition bias)

All outcomes 
Adetoro 1990 (Continued)

Selective reporting (re- Unclear risk No protocol or trial registration described. porting bias)

Other bias Low risk None identified, no baseline imbalance.

Andersen 1989

\section{Study characteristics}

\begin{tabular}{|c|c|}
\hline Methods & $\begin{array}{l}\text { Study design: randomised trial (multi-centre) } \\
\text { Follow-up: } 82.7 \%\end{array}$ \\
\hline Participants & $\begin{array}{l}\text { Age: > } 18 \\
\text { Country: Europe (Denmark, Finland, France, Germany, Norway, the Netherlands) } \\
\text { Setting: not specified ( } 16 \text { centres in various European countries) } \\
\text { Diagnosis: mycological culture and microscopy } \\
\text { Characteristics: non-lactating } \\
\text { Enrolled: } 372 \text { enrolled: } 369 \text { randomised }\end{array}$ \\
\hline Interventions & $\begin{array}{l}\text { Group 1: fluconazole (oral) } 150 \mathrm{mg} \text { single dose }(n=188) \\
\text { Group 2: clotrimazole } 200 \mathrm{mg} \text { vaginal tablets for } 3 \text { days. }(n=181) \\
\text { Duration: not specified }\end{array}$ \\
\hline Outcomes & $\begin{array}{l}\text { Assessed at } 5 \text { - } 16 \text { days and } 27-62 \text { days. } \\
\text { Efficacy } \\
\text { Clinical improvement: response/relief from symptoms and elimination of signs of vaginal infec- } \\
\text { tion.Quote: "Favourable" clinical response if cured or improved. } \\
\text { Mycological cure: eradication of Candida (negative culture and microscopy) } \\
\text { Safety: no withdrawals due to side effects reported } \\
\text { Side effects: participant reported side effects. } \\
\text { Treatment preference: reported for one study centre. } \\
\text { Time to first relief: reported - median time to first relief } \\
\text { Costs: not assessed }\end{array}$ \\
\hline Notes & $\begin{array}{l}\text { Compliance checks: not specified } \\
\text { Pharmaceutical industry support: yes - Pfizer Central Research, Sandwich, England } \\
\% \text { follow-up calculated based on number randomised }\end{array}$ \\
\hline
\end{tabular}

\section{Risk of bias}

\begin{tabular}{lll}
\hline Bias & Authors' judgement & Support for judgement \\
\hline $\begin{array}{l}\text { Random sequence genera- } \\
\text { tion (selection bias) }\end{array}$ & Low risk & Computer-generated randomisation list, probably random. \\
\hline $\begin{array}{l}\text { Allocation concealment } \\
\text { (selection bias) }\end{array}$ & High risk & No description but high risk due to block size of four. \\
\hline $\begin{array}{l}\text { Blinding of participants } \\
\text { and personnel (perfor- } \\
\text { mance bias) }\end{array}$ & High risk & Not possible, given nature of intervention. \\
\hline
\end{tabular}

Oral versus intra-vaginal imidazole and triazole anti-fungal treatment of uncomplicated vulvovaginal candidiasis (thrush) (Review) 
Andersen 1989 (Continued)

All outcomes

Blinding of outcome as-
sessment (detection bias) $\quad$ High risk Not possible given nature of intervention and symptoms.

sessment (detection bias)

Time to First Relief

\begin{tabular}{lll}
\hline $\begin{array}{l}\text { Blinding of outcome as- } \\
\text { sessment (detection bias) } \\
\text { Mycological Cure }\end{array}$ & Low risk & $\begin{array}{l}\text { Testing done by lab cultures, which are objective outcomes, not influenced by } \\
\text { blinding. }\end{array}$ \\
\hline $\begin{array}{l}\text { Blinding of outcome as- } \\
\text { sessment (detection bias) } \\
\text { Mycological Improvement }\end{array}$ & Low risk & $\begin{array}{l}\text { Testing done by lab cultures, which are objective outcomes, not influenced by } \\
\text { blinding. }\end{array}$ \\
\hline $\begin{array}{l}\text { Blinding of outcome as- } \\
\text { sessment (detection bias) } \\
\text { Clinical Cure }\end{array}$ & High risk & $\begin{array}{l}\text { Not possible to avoid risk given nature of intervention, and subjective out- } \\
\text { come. }\end{array}$
\end{tabular}

\begin{tabular}{lll}
\hline Blinding of outcome as- & High risk & Not possible to avoid risk given nature of intervention, and subjective out- \\
sessment (detection bias) & & come.
\end{tabular}

Clinical Improvement

High risk

Blinding of outcome assessment (detection bias)

Side Effects
Not possible to avoid risk given nature of intervention, and subjective outcome.

\begin{tabular}{lll}
\hline $\begin{array}{l}\text { Incomplete outcome data } \\
\text { (attrition bias) } \\
\text { All outcomes }\end{array}$ & High risk & $\begin{array}{l}\text { Greater than 10\% without data (13 one group, 17 in other) with no reason giv- } \\
\text { en. }\end{array}$ \\
\hline $\begin{array}{l}\text { Selective reporting (re- } \\
\text { porting bias) }\end{array}$ & Unclear risk & No protocol described. \\
\hline Other bias & Low risk & None identified, no baseline imbalance. \\
\hline
\end{tabular}

Boag 1991

\section{Study characteristics}

\begin{tabular}{ll}
\hline Methods & $\begin{array}{l}\text { Study design: randomised trial } \\
\text { Follow-up: } 90.9 \%\end{array}$ \\
\hline Participants & $\begin{array}{l}\text { Age: not specified } \\
\text { Country: UK } \\
\text { Setting: Genito-urinary medicine clinic (London) } \\
\text { Diagnosis: mycological culture and clinical symptoms } \\
\text { Characteristics: non-lactating }\end{array}$ \\
& Enrolled: 23 (22 evaluable) \\
\hline Interventions & $\begin{array}{l}\text { Group 1: fluconazole (oral) } 150 \text { mg single dose }(n=11) \\
\text { Group 2: clotrimazole } 500 \text { mg pessary (single dose) }(n=11) \\
\text { Duration: not specified }\end{array}$ \\
\hline
\end{tabular}

Outcomes Assessed at 2, 4, 6 and 10 days after treatment.

\section{Efficacy}


Boag 1991 (Continued)

Mycological cure: no yeasts isolated

Clinical cure: not assessed

Safety: not assessed

Side effects: not assessed

Treatment preference: not assessed

Time to first relief: not assessed

Costs: not assessed

Notes

Compliance check: done E (nurse-administered) all 22 (100\%) patients were compliant with treatment. Pharmaceutical industry support: not specified

\section{Risk of bias}

\begin{tabular}{lll}
\hline Bias & Authors' judgement & Support for judgement \\
\hline $\begin{array}{l}\text { Random sequence genera- } \\
\text { tion (selection bias) }\end{array}$ & Unclear risk & No description provided. \\
\hline $\begin{array}{l}\text { Allocation concealment } \\
\text { (selection bias) }\end{array}$ & Unclear risk & No description provided. \\
\hline $\begin{array}{l}\text { Blinding of participants } \\
\begin{array}{l}\text { and personnel (perfor- } \\
\text { mance bias) }\end{array}\end{array}$ & High risk & Not possible given nature of intervention. \\
All outcomes & \\
\hline
\end{tabular}

\begin{tabular}{lll}
\hline $\begin{array}{l}\text { Blinding of outcome as- } \\
\text { sessment (detection bias) } \\
\text { Time to First Relief }\end{array}$ & High risk & $\begin{array}{l}\text { Not possible to avoid risk given nature of intervention, and subjective out- } \\
\text { come. }\end{array}$ \\
\hline $\begin{array}{l}\text { Blinding of outcome as- } \\
\text { sessment (detection bias) } \\
\text { Mycological Cure }\end{array}$ & Low risk & $\begin{array}{l}\text { Testing done by lab cultures, which are objective outcomes, not influenced by } \\
\text { blinding. }\end{array}$ \\
\hline $\begin{array}{l}\text { Blinding of outcome as- } \\
\text { sessment (detection bias) } \\
\text { Mycological Improvement }\end{array}$ & Low risk & $\begin{array}{l}\text { Testing done by lab cultures, which are objective outcomes, not influenced by } \\
\text { blinding. }\end{array}$ \\
\hline $\begin{array}{l}\text { Blinding of outcome as- } \\
\text { sessment (detection bias) } \\
\text { Clinical Cure }\end{array}$ & High risk & $\begin{array}{l}\text { Not possible to avoid risk given nature of intervention, and subjective out- } \\
\text { come. }\end{array}$ \\
\hline
\end{tabular}

$\begin{array}{lll}\begin{array}{l}\text { Blinding of outcome as- } \\ \text { sessment (detection bias) }\end{array} & \text { High risk } & \begin{array}{l}\text { Not possible to avoid risk given nature of intervention, and subjective out- } \\ \text { come. }\end{array}\end{array}$

Clinical Improvement come.

$\begin{array}{lll}\text { Blinding of outcome as- } & \text { High risk } & \text { Not possible to avoid risk given nature of intervention, and subjective out- } \\ \text { sessment (detection bias) } & \text { come. }\end{array}$
Side Effects

Incomplete outcome data Low risk Only one of 23 patients lost to follow-up.
(attrition bias)

All outcomes 
Boag 1991 (Continued)

Selective reporting (re- Unclear risk $\quad$ No protocol described.
porting bias)

Other bias Unclear risk Baseline data not reported.

\section{Coric 2006}

\section{Study characteristics}

\begin{tabular}{ll}
\hline Methods & Study design: randomised trial \\
& Follow-up: $100 \%$ \\
\hline Participants & Age: not specified \\
& Pregnancy status: not specified \\
& Country: Croatia \\
& Ethnicity: unspecified \\
& Setting: O\&G OPD, University of Zagreb \\
& Diagnosis: mycological \\
Enrolled: 119
\end{tabular}

Interventions $\quad$ Group 1: fluconazole (oral) $(\mathrm{n}=60) 150 \mathrm{mg}$ single dose
Group 2: clotrimazole vaginal tablet $200 \mathrm{mg}$ once daily for 3 days $(\mathrm{n}=59)$
Duration: September 2004 to July 2005

Outcomes Assessed at 24 hours and 14 days

\section{Efficacy}

Mycologocal cure: negative culture

Clinical cure: complete relief of symptoms.

Safety: not assessed

Side effects: not assessed

Treatment preference: reported (oral)

Time to first relief: reported - onset of symptomatic relief in the first 24 hours of treatment

Costs: not assessed

\begin{tabular}{ll}
\hline Notes & Compliance: not specified \\
& Pharmaceutical industry support: not specified \\
\hline Risk of bias & \\
\hline Bias $\quad$ Authors' judgement Support for judgement \\
\hline
\end{tabular}


Coric 2006 (Continued)

\begin{tabular}{|c|c|c|}
\hline $\begin{array}{l}\text { Random sequence genera- } \\
\text { tion (selection bias) }\end{array}$ & Unclear risk & No description provided. \\
\hline $\begin{array}{l}\text { Allocation concealment } \\
\text { (selection bias) }\end{array}$ & Unclear risk & No description provided. \\
\hline $\begin{array}{l}\text { Blinding of participants } \\
\text { and personnel (perfor- } \\
\text { mance bias) } \\
\text { All outcomes }\end{array}$ & High risk & Not possible given nature of intervention. \\
\hline $\begin{array}{l}\text { Blinding of outcome as- } \\
\text { sessment (detection bias) } \\
\text { Time to First Relief }\end{array}$ & High risk & $\begin{array}{l}\text { Not possible to avoid risk given nature of intervention, and subjective out- } \\
\text { come. }\end{array}$ \\
\hline $\begin{array}{l}\text { Blinding of outcome as- } \\
\text { sessment (detection bias) } \\
\text { Mycological Cure }\end{array}$ & Low risk & $\begin{array}{l}\text { Testing done by lab cultures, which are objective outcomes, not influenced by } \\
\text { blinding. }\end{array}$ \\
\hline $\begin{array}{l}\text { Blinding of outcome as- } \\
\text { sessment (detection bias) } \\
\text { Mycological Improvement }\end{array}$ & Low risk & $\begin{array}{l}\text { Testing done by lab cultures, which are objective outcomes, not influenced by } \\
\text { blinding. }\end{array}$ \\
\hline $\begin{array}{l}\text { Blinding of outcome as- } \\
\text { sessment (detection bias) } \\
\text { Clinical Cure }\end{array}$ & High risk & $\begin{array}{l}\text { Not possible to avoid risk given nature of intervention, and subjective out- } \\
\text { come. }\end{array}$ \\
\hline
\end{tabular}

\begin{tabular}{lll}
\hline $\begin{array}{l}\text { Blinding of outcome as- } \\
\text { sessment (detection bias) } \\
\text { Clinical Improvement }\end{array}$ & High risk & Not possible to avoid risk given nature of intervention, and self-report. \\
\hline $\begin{array}{l}\text { Blinding of outcome as- } \\
\text { sessment (detection bias) } \\
\text { Side Effects }\end{array}$ & High risk & $\begin{array}{l}\text { Not possible to avoid risk given nature of intervention, and subjective out- } \\
\text { come. }\end{array}$ \\
\hline $\begin{array}{l}\text { Incomplete outcome data } \\
\begin{array}{l}\text { (attrition bias) } \\
\text { All outcomes }\end{array}\end{array}$ & Low risk & All participants had outcome measures \\
\hline $\begin{array}{l}\text { Selective reporting (re- } \\
\text { porting bias) }\end{array}$ & Unclear risk & No protocol described \\
\hline \begin{tabular}{l} 
Other bias \\
\hline
\end{tabular} & Unclear risk & None identified, but unable to assess baseline imbalance \\
\hline
\end{tabular}

Goode 1992

\section{Study characteristics}

\begin{tabular}{ll}
\hline Methods & $\begin{array}{l}\text { Study design: randomised trial } \\
\text { Follow-up: } 42.9 \% \text { (16 of } 28 \text { participants were excluded due to negative culture at baseline. All remain- } \\
\text { ing participants were followed up.) }\end{array}$ \\
\hline Participants & Age: not specified \\
& Country: USA \\
& Setting: not specified \\
& Diagnosis: mycological culture
\end{tabular}


Goode 1992 (Continued)

Characteristics: not specified

Enrolled: $n=28$ (12 evaluable)

Interventions $\quad$ Group 1: fluconazole (oral) $150 \mathrm{mg}$ single dose $(\mathrm{n}=14)$
Group 2: clotrimazole vaginal tablets $100 \mathrm{mg}$ for 7 days. $(\mathrm{n}=14)$

Duration: seven days (not otherwise specified)

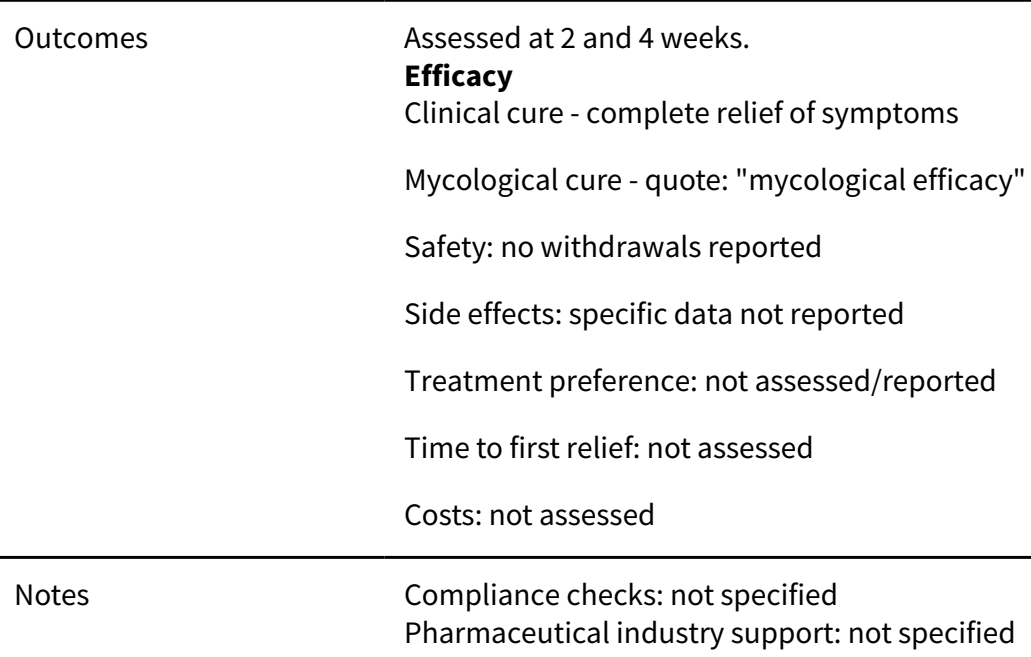

\section{Risk of bias}

\begin{tabular}{lll}
\hline Bias & Authors' judgement & Support for judgement \\
\hline $\begin{array}{l}\text { Random sequence genera- } \\
\text { tion (selection bias) }\end{array}$ & Unclear risk & Not specified. \\
\hline $\begin{array}{l}\text { Allocation concealment } \\
\text { (selection bias) }\end{array}$ & Unclear risk & Not specified. \\
\hline $\begin{array}{l}\text { Blinding of participants } \\
\text { and personnel (perfor- } \\
\text { mance bias) } \\
\begin{array}{l}\text { All outcomes } \\
\text { nigh risk }\end{array}\end{array}$ & Not possible given nature of intervention. \\
\end{tabular}

\begin{tabular}{|c|c|c|}
\hline $\begin{array}{l}\text { Blinding of outcome as- } \\
\text { sessment (detection bias) } \\
\text { Time to First Relief }\end{array}$ & High risk & Not possible to avoid risk given nature of intervention, and self-report. \\
\hline $\begin{array}{l}\text { Blinding of outcome as- } \\
\text { sessment (detection bias) } \\
\text { Mycological Cure }\end{array}$ & Low risk & $\begin{array}{l}\text { Testing done by lab cultures, which are objective outcomes, not influenced by } \\
\text { blinding. }\end{array}$ \\
\hline $\begin{array}{l}\text { Blinding of outcome as- } \\
\text { sessment (detection bias) } \\
\text { Mycological Improvement }\end{array}$ & Unclear risk & $\begin{array}{l}\text { Testing done by lab cultures, which are objective outcomes, not influenced by } \\
\text { blinding. }\end{array}$ \\
\hline
\end{tabular}

Blinding of outcome as- High risk

Not possible to avoid risk given nature of intervention, and self-report.

sessment (detection bias)

Clinical Cure

Blinding of outcome as-

High risk

Not possible to avoid risk given nature of intervention, and self-report.

sessment (detection bias)

Oral versus intra-vaginal imidazole and triazole anti-fungal treatment of uncomplicated vulvovaginal candidiasis (thrush) (Review) 
Goode 1992 (Continued)

Clinical Improvement

Blinding of outcome as-
sessment (detection bias) $\quad$ High risk $\quad$ Not possible to avoid risk given nature of intervention, and self-report.

Side Effects

Incomplete outcome data Low risk High number of dropouts but justified in text.

(attrition bias)

All outcomes

Selective reporting (re- Unclear risk $\quad$ No protocol available.
porting bias)

porting bias)

Other bias Unclear risk Possible baseline imbalance, unclear of impact.

Mendling 2004

\section{Study characteristics}

\begin{tabular}{ll}
\hline Methods & Study design: randomised trial \\
& Follow-up: 472 out of $679(69.5 \%)$ participants were included in the per-protocol population. Reasons \\
& for the exclusions were not provided.
\end{tabular}

\begin{tabular}{ll}
\hline Participants & Age: not specified \\
Country: Germany & Setting: not specified outpatient multi-centre \\
Diagnosis: visual examination, $\mathrm{KOH}$, mycological culture \\
Characteristics: not specified \\
Enrolled: 679 (472 evaluable)
\end{tabular}

\begin{tabular}{ll}
\hline Interventions & Group 1: clotrimazole $500 \mathrm{mg}$ vaginal tablet single dose $\mathrm{n}=226$ \\
& Group 2: clotrimazole $10 \%$ vaginal cream in a single dose applicator $\mathrm{n}=226$ \\
& Group 3: fluconazole (oral) $150 \mathrm{mg}$ single dose $\mathrm{n}=227$ \\
& Duration: not specified \\
\hline
\end{tabular}

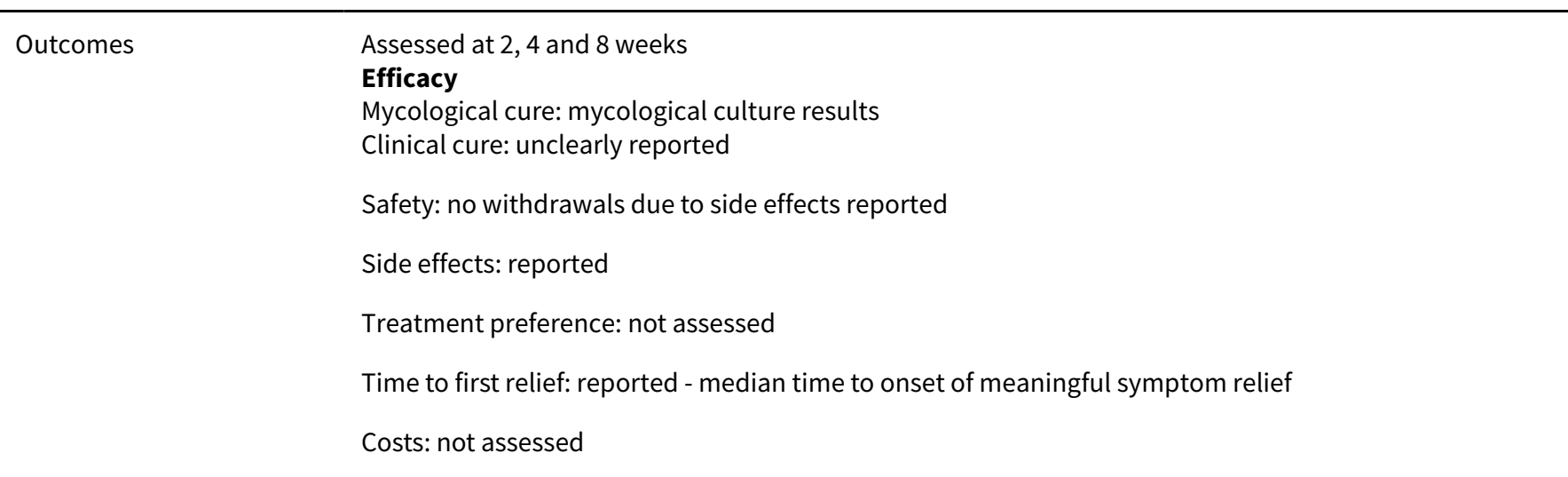

\begin{tabular}{ll}
\hline Notes & Compliance checks: not specified \\
& Pharmaceutical industry support: not specified
\end{tabular}

\section{Risk of bias}

Oral versus intra-vaginal imidazole and triazole anti-fungal treatment of uncomplicated vulvovaginal candidiasis (thrush) (Review) 
Mendling 2004 (Continued)

\begin{tabular}{lll} 
Bias & Authors' judgement & Support for judgement \\
\hline $\begin{array}{l}\text { Random sequence genera- } \\
\text { tion (selection bias) }\end{array}$ & Unclear risk & No description provided. \\
\hline $\begin{array}{l}\text { Allocation concealment } \\
\text { (selection bias) }\end{array}$ & Unclear risk & No description provided.
\end{tabular}

Blinding of participants High risk Not possible to avoid risk given nature of intervention.
and personnel (perfor-
mance bias)
All outcomes

omes

High risk

Not possible to avoid risk given nature of intervention, and self-report.

sessment (detection bias)

Time to First Relief

\begin{tabular}{lll}
\hline $\begin{array}{l}\text { Blinding of outcome as- } \\
\text { sessment (detection bias) } \\
\text { Mycological Cure }\end{array}$ & Low risk & $\begin{array}{l}\text { Testing done by lab cultures, which are objective outcomes, not influenced by } \\
\text { blinding. }\end{array}$
\end{tabular}

\begin{tabular}{lll}
\hline $\begin{array}{l}\text { Blinding of outcome as- } \\
\text { sessment (detection bias) } \\
\text { Mycological Improvement }\end{array}$ & Low risk & $\begin{array}{l}\text { Testing done by lab cultures, which are objective outcomes, not influenced by } \\
\text { blinding. }\end{array}$ \\
\hline $\begin{array}{l}\text { Blinding of outcome as- } \\
\text { sessment (detection bias) } \\
\text { Clinical Cure }\end{array}$ & High risk & Not possible to avoid risk given nature of intervention, and self-report. \\
\hline
\end{tabular}

\begin{tabular}{|c|c|c|}
\hline $\begin{array}{l}\text { Blinding of outcome as- } \\
\text { sessment (detection bias) } \\
\text { Clinical Improvement }\end{array}$ & High risk & Not possible to avoid risk given nature of intervention, and self-report. \\
\hline $\begin{array}{l}\text { Blinding of outcome as- } \\
\text { sessment (detection bias) } \\
\text { Side Effects }\end{array}$ & High risk & Not possible to avoid risk given nature of intervention, and self-report. \\
\hline $\begin{array}{l}\text { Incomplete outcome data } \\
\text { (attrition bias) } \\
\text { All outcomes }\end{array}$ & High risk & $\begin{array}{l}\text { Over } 25 \% \text { lost to follow-up in all groups with no explanation. However, ITT da- } \\
\text { ta also reported. }\end{array}$ \\
\hline $\begin{array}{l}\text { Selective reporting (re- } \\
\text { porting bias) }\end{array}$ & Unclear risk & No protocol described. \\
\hline Other bias & Unclear risk & No baseline data presented. \\
\hline
\end{tabular}

Mikamo 1995

\section{Study characteristics}

\begin{tabular}{ll}
\hline Methods & $\begin{array}{l}\text { Study design: randomised trial } \\
\text { Follow-up: no description of number of participants lost to follow-up }\end{array}$ \\
\hline Participants & Age: $18-54$ \\
& Country: Japan \\
& Setting: O\&G OPD (single centre) \\
\hline
\end{tabular}

Oral versus intra-vaginal imidazole and triazole anti-fungal treatment of uncomplicated vulvovaginal candidiasis (thrush) (Review) 
Mikamo 1995 (Continued)

Diagnosis: mycological culture

Characteristics: non-pregnant and non-lactating

Enrolled: 150

\begin{tabular}{ll}
\hline Interventions & Group 1: fluconazole (oral) $150 \mathrm{mg}$ single dose $(\mathrm{N}=50)$ \\
& Group 2: clotrimazole (vaginal) $100 \mathrm{mg}$ for 6 days. $(\mathrm{N}=50)$ \\
Group 3: fluconazole (oral) $50 \mathrm{mg}$ daily for 6 days ( $\mathrm{n}=50$ women)
\end{tabular}

Assessed at 5-15 days and 30-60 days.
Efficacy
Clinical cure - complete disappearance of presenting signs and symptoms
Mycological cure: negative culture and microscopy for Candida species
Safety: no withdrawals due to adverse drug reaction.
Side effects: quote: "No adverse drug effects were noted"
Treatment preference: not assessed
Time to first relief: not assessed
Costs: not assessed

\begin{tabular}{ll}
\hline Notes & Compliance checks: not specified \\
& Pharmaceutical industry support: not specified
\end{tabular}

\section{Risk of bias}

\begin{tabular}{|c|c|c|}
\hline Bias & Authors' judgement & Support for judgement \\
\hline $\begin{array}{l}\text { Random sequence genera- } \\
\text { tion (selection bias) }\end{array}$ & Unclear risk & No description provided. \\
\hline $\begin{array}{l}\text { Allocation concealment } \\
\text { (selection bias) }\end{array}$ & Unclear risk & No description provided. \\
\hline $\begin{array}{l}\text { Blinding of participants } \\
\text { and personnel (perfor- } \\
\text { mance bias) } \\
\text { All outcomes }\end{array}$ & High risk & Not possible to avoid risk given nature of intervention, and self-report. \\
\hline $\begin{array}{l}\text { Blinding of outcome as- } \\
\text { sessment (detection bias) } \\
\text { Time to First Relief }\end{array}$ & High risk & Not possible to avoid risk given nature of intervention, and self-report. \\
\hline $\begin{array}{l}\text { Blinding of outcome as- } \\
\text { sessment (detection bias) } \\
\text { Mycological Cure }\end{array}$ & Low risk & $\begin{array}{l}\text { Testing done by lab cultures, which are objective outcomes, not influenced by } \\
\text { blinding. }\end{array}$ \\
\hline $\begin{array}{l}\text { Blinding of outcome as- } \\
\text { sessment (detection bias) } \\
\text { Mycological Improvement }\end{array}$ & Low risk & $\begin{array}{l}\text { Testing done by lab cultures, which are objective outcomes, not influenced by } \\
\text { blinding. }\end{array}$ \\
\hline $\begin{array}{l}\text { Blinding of outcome as- } \\
\text { sessment (detection bias) } \\
\text { Clinical Cure }\end{array}$ & High risk & Not possible to avoid risk given nature of intervention, and self-report. \\
\hline
\end{tabular}

Blinding of outcome as-
sessment (detection bias) $\quad$ High risk Not possible to avoid risk given nature of intervention, and self-report.


Mikamo 1995 (Continued)

Clinical Improvement

Blinding of outcome as-
sessment (detection bias) $\quad$ High risk Not possible to avoid risk given nature of intervention, and self-report.

sessment (detection bias)

Side Effects

Incomplete outcome data Unclear risk $\quad$ No description of number of participants lost to follow-up.
(attrition bias)

All outcomes

Selective reporting (re- Unclear risk $\quad$ No protocol described.
porting bias)

porting bias)

\begin{tabular}{ll}
\hline Other bias $\quad$ Low risk $\quad$ Baseline data shows that age varies by 5 years, minimal difference in weight. \\
\hline
\end{tabular}

Murina 2012

\section{Study characteristics}

\begin{tabular}{ll}
\hline Methods & Study design: randomised trial \\
& Follow-up: $100 \%$ \\
\hline Participants & Age: median of 26 years in the oral treatment group and 25 years in the intra-vaginal treatment group \\
& Country: Italy \\
& Setting: not specified \\
& Diagnosis: lab test, reported symptoms \\
& Characteristic: non-pregnant \\
& Enrolled: 80 \\
Group 1; fluconazole oral 150 mg repeat dose (N=40) \\
Group 2: fenticonazole (intra-vaginal) $600 \mathrm{mg}(\mathrm{N}=40)$ repeat dose on day 3 \\
Duration: not specified
\end{tabular}

Outcomes Assessed at day 7 and $30+/-5$ days

\section{Efficacy}

Mycological cure: bot assessed

Clinical cure: responders

Safety: Reported - quote: "no patient belonging to the two groups had to suspend treatment due to the presence of severe side effects."

Side effects: reported - quote: "Three women reported transient nausea after taking fluconazole, while two patients showed burning sensation short vaginal discharge after insertion vaginal fenticonazole."

Treatment preference: not assessed

Time to first relief: reported mean time to first relief of vulvovaginal pruritus

Costs: not assessed 
Murina 2012 (Continued)

$\begin{array}{ll}\text { Notes } & \text { Compliance checks: not specified } \\ \text { Pharmaceutical industry support: not specified }\end{array}$

\section{Risk of bias}

\begin{tabular}{lll}
\hline Bias & Authors' judgement & Support for judgement \\
\hline $\begin{array}{l}\text { Random sequence genera- } \\
\text { tion (selection bias) }\end{array}$ & Unclear risk & No description provided. \\
\hline $\begin{array}{l}\text { Allocation concealment } \\
\text { (selection bias) }\end{array}$ & Unclear risk & No description provided. \\
\hline $\begin{array}{l}\text { Blinding of participants } \\
\text { and personnel (perfor- } \\
\text { mance bias) } \\
\text { All outcomes }\end{array}$ & High risk & Not possible to avoid risk given nature of intervention. \\
\hline
\end{tabular}

Blinding of outcome as-
sessment (detection bias) $\quad$ High risk $\quad$ Not possible to avoid risk given nature of intervention, and self-report.

Time to First Relief

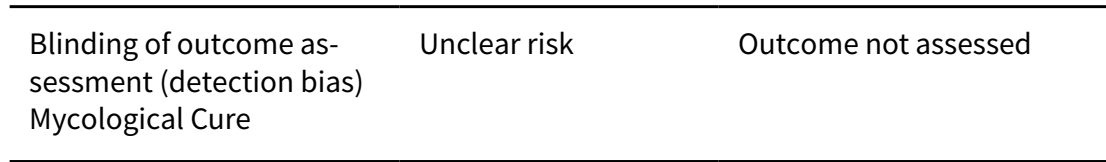

\begin{tabular}{|c|c|c|}
\hline $\begin{array}{l}\text { Blinding of outcome as- } \\
\text { sessment (detection bias) } \\
\text { Mycological Improvement }\end{array}$ & Unclear risk & Outcome not assessed \\
\hline $\begin{array}{l}\text { Blinding of outcome as- } \\
\text { sessment (detection bias) } \\
\text { Clinical Cure }\end{array}$ & High risk & Not possible to avoid risk given nature of intervention, and self-report. \\
\hline $\begin{array}{l}\text { Blinding of outcome as- } \\
\text { sessment (detection bias) } \\
\text { Clinical Improvement }\end{array}$ & High risk & Not possible to avoid risk given nature of intervention, and self-report. \\
\hline $\begin{array}{l}\text { Blinding of outcome as- } \\
\text { sessment (detection bias) } \\
\text { Side Effects }\end{array}$ & High risk & Not possible to avoid risk given nature of intervention, and self-report. \\
\hline $\begin{array}{l}\text { Incomplete outcome data } \\
\text { (attrition bias) } \\
\text { All outcomes }\end{array}$ & Low risk & All participants had outcome measures. \\
\hline $\begin{array}{l}\text { Selective reporting (re- } \\
\text { porting bias) }\end{array}$ & Unclear risk & No culture data. No protocol described. \\
\hline Other bias & Low risk & None identified, no baseline imbalance. \\
\hline
\end{tabular}

\section{O-Prasertsawat 1995}

\section{Study characteristics}

Methods Study design: randomised trial

Oral versus intra-vaginal imidazole and triazole anti-fungal treatment of uncomplicated vulvovaginal candidiasis (thrush) (Review) 
O-Prasertsawat 1995 (Continued)

\author{
Follow-up: $95.1 \%$
}

\begin{tabular}{|c|c|}
\hline Participants & $\begin{array}{l}\text { Age: } 25-43 \text { years } \\
\text { Country: Thailand (Bangkok) } \\
\text { Setting: Hospital obstetrics and gynaecology out-patient department } \\
\text { Diagnosis: visual examination, mycological culture and clinical sympt } \\
\text { Enrolled: } 110 \text { (103 evaluable) }\end{array}$ \\
\hline Interventions & $\begin{array}{l}\text { Group 1: fluconazole (oral) } 150 \mathrm{mg} \text { single dose }(n=53) \\
\text { Group 2: clotrimazole vaginal tablets } 200 \mathrm{mg} \text { for } 3 \text { days. }(n=50) \\
\text { Duration: June 1, } 1993 \text { to September } 30.1993\end{array}$ \\
\hline Outcomes & $\begin{array}{l}\text { Assessed at } 1 \text { and } 4 \text { weeks. } \\
\text { Efficacy } \\
\text { Clinical cure: not reported } \\
\text { Mycological cure - failure to grow Candida species. } \\
\text { Safety: no withdrawals due to side effects reported } \\
\text { Side effects: reported side effects (nausea. dizziness, vaginal burning) } \\
\text { Treatment preference: not reported } \\
\text { Time to first relief: not assessed } \\
\text { Costs:not assessed }\end{array}$ \\
\hline
\end{tabular}

Notes Compliance Check: yes - participant questioned regarding use of anti-fungal drugs. No other data reported.

Pharmaceutical industry support: not specified

The denominator for each outcome was based upon the number randomised as the authors did not indicate at what stage the patient withdrawals from the study occurred.

\title{
Risk of bias
}

\begin{tabular}{|c|c|c|}
\hline Bias & Authors' judgement & Support for judgement \\
\hline $\begin{array}{l}\text { Random sequence genera- } \\
\text { tion (selection bias) }\end{array}$ & Low risk & $\begin{array}{l}\text { Each patient chose one of two identical boxes, investigator not aware of which } \\
\text { treatment patient chose. }\end{array}$ \\
\hline $\begin{array}{l}\text { Allocation concealment } \\
\text { (selection bias) }\end{array}$ & Low risk & $\begin{array}{l}\text { Each patient chose one of two identical boxes, investigator not aware of which } \\
\text { treatment patient chose. }\end{array}$ \\
\hline $\begin{array}{l}\text { Blinding of participants } \\
\text { and personnel (perfor- } \\
\text { mance bias) } \\
\text { All outcomes }\end{array}$ & High risk & Not possible to avoid risk given nature of intervention. \\
\hline $\begin{array}{l}\text { Blinding of outcome as- } \\
\text { sessment (detection bias) } \\
\text { Time to First Relief }\end{array}$ & High risk & Not possible to avoid risk given nature of intervention and self-report. \\
\hline $\begin{array}{l}\text { Blinding of outcome as- } \\
\text { sessment (detection bias) } \\
\text { Mycological Cure }\end{array}$ & Low risk & $\begin{array}{l}\text { Testing done by lab cultures, which are objective outcomes, not influenced by } \\
\text { blinding. }\end{array}$ \\
\hline
\end{tabular}




\section{O-Prasertsawat 1995 (Continued)} sessment (detection bias)

Mycological Improvement
Low risk

blinding

Testing done by lab cultures, which are objective outcomes, not influenced by blinding.

Blinding of outcome assessment (detection bias) Clinical Cure

\section{Blinding of outcome as- sessment (detection bias) \\ Clinical Improvement}

\begin{tabular}{lll}
\hline $\begin{array}{l}\text { Blinding of outcome as- } \\
\text { sessment (detection bias) } \\
\text { Side Effects }\end{array}$ & High risk & Not possible to avoid risk \\
\hline $\begin{array}{l}\text { Incomplete outcome data } \\
\text { (attrition bias) }\end{array}$ & Low risk & No loss to follow-up \\
All outcomes & &
\end{tabular}

\begin{tabular}{lll}
\hline $\begin{array}{l}\text { Selective reporting (re- } \\
\text { porting bias) }\end{array}$ & Unclear risk & No protocol described \\
\hline Other bias & Low risk & Only age comparison provided. \\
\hline
\end{tabular}

\section{Osser 1991}

\section{Study characteristics}

\begin{tabular}{|c|c|}
\hline Methods & $\begin{array}{l}\text { Study design: randomised trial } \\
\text { Follow-up: } 91.1 \%\end{array}$ \\
\hline Interventions & $\begin{array}{l}\text { Group 1: Econazole } 150 \mathrm{mg} \text { vaginal depot tablet, single dose. ( } n=130) \text { (114 evaluable) } \\
\text { Group 2: Fluconazole (oral) 150mg single dose. }(n=128)(121 \text { evaluable) } \\
\text { Duration: August } 1989 \text { to February } 1990\end{array}$ \\
\hline Outcomes & $\begin{array}{l}\text { Measured at } 7-10 \text { days, } 28-35 \text { days and } 80-100 \text { days. } \\
\text { Efficacy } \\
\text { Mycological cure - mycological culture - absence of yeast fungi } \\
\text { Clinical cure. - absence of symptoms } \\
\text { Safety: no withdrawals due to side effects reported } \\
\text { Side effects: participant reported side effects (gastro-intestinal symptoms, introital burning, vaginal } \\
\text { discharge) } \\
\text { Treatment preference:reported }\end{array}$ \\
\hline
\end{tabular}

Oral versus intra-vaginal imidazole and triazole anti-fungal treatment of uncomplicated vulvovaginal candidiasis (thrush) (Review) 
Osser 1991 (Continued)

Time to first relief: not assessed

Costs: not assessed

Notes Compliance check: yes - questioning at 7-10 day follow-up. 235 participants (100\%) were compliant with treatment.

Pharmaceutical industry support: yes - Pfizer AB

19 fluconazole and 14 econazole participants had experienced at least 3 episodes of VVC in the previous 12 months.

This trial had a lower age limit of 15 years old in their age criteria, however the participants were all aged 16 years and over.

\section{Risk of bias}

\begin{tabular}{|c|c|c|}
\hline Bias & Authors' judgement & Support for judgement \\
\hline $\begin{array}{l}\text { Random sequence genera- } \\
\text { tion (selection bias) }\end{array}$ & Unclear risk & No description provided. \\
\hline $\begin{array}{l}\text { Allocation concealment } \\
\text { (selection bias) }\end{array}$ & Unclear risk & No description provided \\
\hline $\begin{array}{l}\text { Blinding of participants } \\
\text { and personnel (perfor- } \\
\text { mance bias) } \\
\text { All outcomes }\end{array}$ & High risk & Not possible to avoid risk given nature of intervention. \\
\hline $\begin{array}{l}\text { Blinding of outcome as- } \\
\text { sessment (detection bias) } \\
\text { Time to First Relief }\end{array}$ & High risk & Not possible to avoid risk given nature of intervention, and self-report. \\
\hline $\begin{array}{l}\text { Blinding of outcome as- } \\
\text { sessment (detection bias) } \\
\text { Mycological Cure }\end{array}$ & Low risk & $\begin{array}{l}\text { Testing done by lab cultures, which are objective outcomes, not influenced by } \\
\text { blinding. }\end{array}$ \\
\hline $\begin{array}{l}\text { Blinding of outcome as- } \\
\text { sessment (detection bias) } \\
\text { Mycological Improvement }\end{array}$ & Low risk & $\begin{array}{l}\text { Testing done by lab cultures, which are objective outcomes, not influenced by } \\
\text { blinding. }\end{array}$ \\
\hline $\begin{array}{l}\text { Blinding of outcome as- } \\
\text { sessment (detection bias) } \\
\text { Clinical Cure }\end{array}$ & High risk & Not possible to avoid risk given nature of intervention, and self-report. \\
\hline $\begin{array}{l}\text { Blinding of outcome as- } \\
\text { sessment (detection bias) } \\
\text { Clinical Improvement }\end{array}$ & High risk & Not possible to avoid risk given nature of intervention, and self-report. \\
\hline $\begin{array}{l}\text { Blinding of outcome as- } \\
\text { sessment (detection bias) } \\
\text { Side Effects }\end{array}$ & High risk & Not possible to avoid risk given nature of intervention, and self-report. \\
\hline $\begin{array}{l}\text { Incomplete outcome data } \\
\text { (attrition bias) } \\
\text { All outcomes }\end{array}$ & Low risk & Small percentage of dropout $<10 \%$. \\
\hline
\end{tabular}

Selective reporting (re- Unclear risk No protocol described.
porting bias) 
Osser 1991 (Continued)

Other bias Low risk Baseline data comparable.

Roongpisuthipong 2010

\section{Study characteristics}

Methods Study design: randomised trial

Follow-up: $94.1 \%$

Age: $15-50$ years old
Country: Thailand (Bangkok)
Setting: single centre Hospital O\&G OPD
Diagnosis: mycologic, $\mathrm{KOH}$
Characteristics: non pregnant
Enrolled: 188 (177 evaluable)

Group 1: fluconazole 150mg (oral), single dose $(\mathrm{n}=67)$
Group 2: Other - Sertaconozole $500 \mathrm{mg}$ (intra-vaginal), single dose $(\mathrm{n}=66)$
Group 3: clotrimazole $100 \mathrm{mg}$, (intra-vaginal), single dose once a day for six consecutive days ( $\mathrm{n}=55)$
Duration: August 31, 2004 to January 30, 2006

Accessed at 1 week and 4 weeks
Efficacy
Mycological cure - no yeast growth
Clinical cure - not assessed
Safety: no withdrawals due to adverse events reported
Side effects: quote: "Results showed minimal side effect without adverse event"
Treatment preference: not assessed
Time to first relief: not assessed
Costs: not assessed

Notes Compliance check: not specified

Pharmaceutical industry support: yes - Pacific Healthcare (Thailand) Co., Ltd

This study was included despite the lower age limit being less than the inclusion criteria for this review (16 years) because only $8 / 188$ participants were in the $15-19$ year age range in this trial.

\section{Risk of bias}

Bias Authors' judgement Support for judgement


Roongpisuthipong 2010 (Continued)
Random sequence genera- Low risk
Computer randomised does not indicate random order, but likely random. tion (selection bias)

\begin{tabular}{lll}
\hline $\begin{array}{l}\text { Allocation concealment } \\
\text { (selection bias) }\end{array}$ & Unclear risk & No description provided.
\end{tabular}

Blinding of participants $\quad$ High risk $\quad$ Not possible to avoid risk given nature of intervention.
and personnel (perfor-
mance bias)
All outcomes

\begin{tabular}{|c|c|c|}
\hline $\begin{array}{l}\text { Blinding of outcome as- } \\
\text { sessment (detection bias) } \\
\text { Time to First Relief }\end{array}$ & Unclear risk & Not reported \\
\hline $\begin{array}{l}\text { Blinding of outcome as- } \\
\text { sessment (detection bias) } \\
\text { Mycological Cure }\end{array}$ & Low risk & $\begin{array}{l}\text { Testing done by lab cultures, which are objective outcomes, not influenced by } \\
\text { blinding. }\end{array}$ \\
\hline
\end{tabular}

\begin{tabular}{|c|c|c|}
\hline $\begin{array}{l}\text { Blinding of outcome as- } \\
\text { sessment (detection bias) } \\
\text { Mycological Improvement }\end{array}$ & Low risk & $\begin{array}{l}\text { Testing done by lab cultures, which are objective outcomes, not influenced by } \\
\text { blinding. }\end{array}$ \\
\hline $\begin{array}{l}\text { Blinding of outcome as- } \\
\text { sessment (detection bias) } \\
\text { Clinical Cure }\end{array}$ & Unclear risk & Outcome not assessed \\
\hline
\end{tabular}

\begin{tabular}{|c|c|c|}
\hline $\begin{array}{l}\text { Blinding of outcome as- } \\
\text { sessment (detection bias) } \\
\text { Clinical Improvement }\end{array}$ & Unclear risk & Outcome not assessed \\
\hline
\end{tabular}

\begin{tabular}{|c|c|c|}
\hline $\begin{array}{l}\text { Blinding of outcome as- } \\
\text { sessment (detection bias) } \\
\text { Side Effects }\end{array}$ & High risk & Not possible to avoid risk given nature of intervention, and self-report. \\
\hline $\begin{array}{l}\text { Incomplete outcome data } \\
\text { (attrition bias) } \\
\text { All outcomes }\end{array}$ & Low risk & $\begin{array}{l}11 \text { total lost to follow-up, evenly distributed. Reasons for lost to follow-up } \\
\text { were not presented. Less than } 10 \% \text { overall. }\end{array}$ \\
\hline $\begin{array}{l}\text { Selective reporting (re- } \\
\text { porting bias) }\end{array}$ & Unclear risk & No clinical outcome events reported. \\
\hline Other bias & Low risk & $\begin{array}{l}\text { Groups roughly comparable. Not sure about funding, but possible funding in- } \\
\text { fluence showing in other criteria. }\end{array}$ \\
\hline
\end{tabular}

Sanam 2009

\section{Study characteristics}

Study design: randomised trial
Follow-up: 7 from the itraconazole group and 5 from the clotrimazole group were excluded because
they were not referred for examination and culture in 10 days after treatment $(<10 \%)$.

Participants

Age: mean $28.1 \pm 4.8$ (itraconazole group) and $28 \pm 5.8$ (clotrimazole group) 
Sanam 2009 (Continued)

\section{Country: Iran}

Setting: single centre O\&G OPD Gynecological outpatient clinic of the University Hospital Amir, Semnan

Diagnosis: mycologic, $\mathrm{KOH}$, visual examination

Characteristics: non-pregnant

Enrolled: 264 (252 evaluable)

Interventions

Group 1: itraconazole (oral) $400 \mathrm{mg}$ two divided dose in a day $(\mathrm{n}=132)$

Group 2: $1 \%$ clotrimazole (intra-vaginal) $5 \mathrm{~g}$ daily for 6 days $(n=132)$

Duration: 1st of June 2006 and 31st of June 2007.

Accessed at day 10
Efficacy
Mycological cure: complete eradication
Clinical cure: no clinical signs and symptoms
Safety: no withdrawals due to side effects reported
Side effects: reported (frequency of micturition, dyspareunia)
Treatment preference: not assessed
Time to first relief: not assessed
Costs: not assessed

Compliance: not specified
Pharmaceutical industry support: not specified

\section{Risk of bias}

\begin{tabular}{|c|c|c|}
\hline Bias & Authors' judgement & Support for judgement \\
\hline $\begin{array}{l}\text { Random sequence genera- } \\
\text { tion (selection bias) }\end{array}$ & Unclear risk & No description provided. \\
\hline $\begin{array}{l}\text { Allocation concealment } \\
\text { (selection bias) }\end{array}$ & Unclear risk & No description provided. \\
\hline $\begin{array}{l}\text { Blinding of participants } \\
\text { and personnel (perfor- } \\
\text { mance bias) } \\
\text { All outcomes }\end{array}$ & High risk & Not possible to avoid risk given nature of intervention.. \\
\hline $\begin{array}{l}\text { Blinding of outcome as- } \\
\text { sessment (detection bias) } \\
\text { Time to First Relief }\end{array}$ & High risk & Not possible to avoid risk given nature of intervention, and self-report. \\
\hline $\begin{array}{l}\text { Blinding of outcome as- } \\
\text { sessment (detection bias) } \\
\text { Mycological Cure }\end{array}$ & Low risk & $\begin{array}{l}\text { Testing done by lab cultures, which are objective outcomes, not influenced by } \\
\text { blinding. }\end{array}$ \\
\hline
\end{tabular}




\section{Sanam 2009 (Continued)}

Blinding of outcome as sessment (detection bias)

Mycological Improvement
Low risk Testing done by lab cultures, which are objective outcomes, not influenced by blinding. sessment (detection bias) Clinical Cure

High risk Not possible to avoid risk given nature of intervention, and self-report.

\title{
Blinding of outcome as- sessment (detection bias) Clinical Improvement
}

\begin{tabular}{lll}
\hline $\begin{array}{l}\text { Blinding of outcome as- } \\
\text { sessment (detection bias) } \\
\text { Side Effects }\end{array}$ & High risk & Not possible to avoid risk given nature of intervention, and self-report. \\
\hline $\begin{array}{l}\text { Incomplete outcome data } \\
\begin{array}{l}\text { (attrition bias) } \\
\text { All outcomes }\end{array}\end{array}$ & Low risk & 12 lost to follow-up (7 and 5$)$ which is $<10 \%$ and comparable in both groups. \\
\hline $\begin{array}{l}\text { Selective reporting (re- } \\
\text { porting bias) }\end{array}$ & Unclear risk & No protocol described \\
\hline Other bias & Low risk & Only age provided as a baseline characteristic. \\
\hline
\end{tabular}

Seidman 2005

\section{Study characteristics}

\begin{tabular}{ll}
\hline Methods & $\begin{array}{l}\text { Study design: randomised trial } \\
\text { Follow-up: unclear }\end{array}$ \\
\hline Participants & Age: 18 years and over \\
& Country: USA \\
& Setting: multi-centre; 13 Research facilities (not specified type) across the USA) \\
& Diagnosis: visual examination, $\mathrm{KOH}$, patient report of signs and symptoms, severity score \\
& Characteristics: non-pregnant \\
& Enrolled: 181
\end{tabular}

Interventions

Group 1: butoconazole $5 \mathrm{~g}$ vaginal cream ( $2 \%$ site release) single dose $(n=93)$

Group 2: fluconazole (oral) $150 \mathrm{mg}$ single dose $(n=88)$

Duration: May to November 2003

\section{Outcomes}

\author{
Assessed hourly by patient report \\ Efficacy \\ Clinical cure: time to total relief of symptoms (measured in hours) \\ Mycological cure: not assessed \\ Safety: no withdrawals due to adverse events reported \\ Side effects: participant reported a range of adverse events (drug and non drug related) \\ Treatment preference: not assessed
}


Time to first relief: reported - median time to first relief (measured in hours) and proportion of patients reporting first relief at 12 and 24 hours post-treatment

Costs: not assessed

Notes
Compliance checks: yes - administered in investigator's office; $100 \%$ compliance. Pharmaceutical industry support: not specified

Patients were provided with a diary and requested to record the date and time they first started to feel relief of symptoms and the date and time they had complete relief of symptoms. Outcomes were calculated using the dosing time and the time reported for each by the patient

\section{Risk of bias}

\begin{tabular}{lll}
\hline Bias & Authors' judgement & Support for judgement \\
\hline $\begin{array}{l}\text { Random sequence genera- } \\
\text { tion (selection bias) }\end{array}$ & Low risk & Computer-generated randomisation.
\end{tabular}

tion (selection bias)

Allocation concealment $\quad$ Unclear risk $\quad$ No description provided.
(selection bias)

Blinding of participants $\quad$ High risk $\quad$ Not possible to avoid risk given nature of intervention.
and personnel (perfor-
mance bias)

\begin{tabular}{lll}
\hline $\begin{array}{l}\text { Blinding of outcome as- } \\
\text { sessment (detection bias) } \\
\text { Time to First Relief }\end{array}$ & High risk & Not possible to avoid risk given nature of intervention, and self-report. \\
\hline $\begin{array}{l}\text { Blinding of outcome as- } \\
\text { sessment (detection bias) } \\
\text { Mycological Cure }\end{array}$ & Unclear risk & Outcome not assessed \\
\hline
\end{tabular}

\begin{tabular}{lll}
\hline Blinding of outcome as- & Unclear risk & Outcome not assessed \\
sessment (detection bias) & \\
Mycological Improvement & \\
\hline
\end{tabular}

$\begin{array}{ll}\text { Blinding of outcome as- } & \text { High risk }\end{array}$ Not possible to avoid risk given nature of intervention, and self-report.

Clinical Cure

\begin{tabular}{|c|c|c|}
\hline $\begin{array}{l}\text { Blinding of outcome as- } \\
\text { sessment (detection bias) } \\
\text { Clinical Improvement }\end{array}$ & High risk & Not possible to avoid risk given nature of intervention, and self-report. \\
\hline $\begin{array}{l}\text { Blinding of outcome as- } \\
\text { sessment (detection bias) } \\
\text { Side Effects }\end{array}$ & High risk & Not possible to avoid risk given nature of intervention, and self-report. \\
\hline $\begin{array}{l}\text { Incomplete outcome data } \\
\text { (attrition bias) } \\
\text { All outcomes }\end{array}$ & Unclear risk & Not described. \\
\hline $\begin{array}{l}\text { Selective reporting (re- } \\
\text { porting bias) }\end{array}$ & Unclear risk & No culture data. \\
\hline Other bias & Low risk & No baseline differences. \\
\hline
\end{tabular}


Sekhavat 2011

\section{Study characteristics}

\begin{tabular}{ll}
\hline Methods & Study design: randomised trial \\
& Follow-up: $91.0 \%$ \\
\hline
\end{tabular}

\begin{tabular}{ll}
\hline Participants & Age: over 15 years of age \\
Country: Iran & Setting: single centre O\&G OPD at the University Shahid Sadoughi hospital in Yazd, Iran \\
& Diagnosis: mycological, clinical symptoms \\
& Characteristics: non-pregnant \\
& Enrolled: 156 (142 evaluable) \\
\hline Group1: fluconazole (oral) $150 \mathrm{mg}$, single dose $(\mathrm{n}=72)$ \\
Group2: clotrimazole (intra-vaginal) $200 \mathrm{mg}$ for 7 days $(\mathrm{n}=70)$ \\
Duration: July 2006 and May 2008 \\
\hline
\end{tabular}

Accessed at 7 days and 1 month
Efficacy
Mycological cure - mycological absence of yeast
Clinical cure - absence of signs and symptoms
Safety: no withdrawals due to side effects reported
Side effects: reported
Treatment preference: reported (oral)
Time to first relief: not assessed
Costs: not assessed
Compliance: Not specified
Pharmaceutical industry support: Not specified

\section{Risk of bias}

\begin{tabular}{lll}
\hline Bias & Authors' judgement & Support for judgement \\
\hline $\begin{array}{l}\text { Random sequence genera- } \\
\text { tion (selection bias) }\end{array}$ & Unclear risk & No description provided. \\
\hline $\begin{array}{l}\text { Allocation concealment } \\
\text { (selection bias) }\end{array}$ & Unclear risk & No description provided. \\
\hline $\begin{array}{l}\text { Blinding of participants } \\
\text { and personnel (perfor- } \\
\text { mance bias) }\end{array}$ & High risk & Not possible to avoid risk given nature of intervention. \\
All outcomes & & \\
\hline
\end{tabular}

Oral versus intra-vaginal imidazole and triazole anti-fungal treatment of uncomplicated vulvovaginal candidiasis (thrush) (Review) 
Sekhavat 2011 (Continued)

Blinding of outcome as- High risk Not possible to avoid risk given nature of intervention, and self-report. sessment (detection bias)

Time to First Relief

\begin{tabular}{|c|c|c|}
\hline $\begin{array}{l}\text { Blinding of outcome as- } \\
\text { sessment (detection bias) } \\
\text { Mycological Cure }\end{array}$ & Low risk & $\begin{array}{l}\text { Testing done by lab cultures, which are objective outcomes, not influenced by } \\
\text { blinding. }\end{array}$ \\
\hline $\begin{array}{l}\text { Blinding of outcome as- } \\
\text { sessment (detection bias) } \\
\text { Mycological Improvement }\end{array}$ & Low risk & $\begin{array}{l}\text { Testing done by lab cultures, which are objective outcomes, not influenced by } \\
\text { blinding. }\end{array}$ \\
\hline $\begin{array}{l}\text { Blinding of outcome as- } \\
\text { sessment (detection bias) } \\
\text { Clinical Cure }\end{array}$ & High risk & Not possible to avoid risk given nature of intervention, and self-report. \\
\hline $\begin{array}{l}\text { Blinding of outcome as- } \\
\text { sessment (detection bias) } \\
\text { Clinical Improvement }\end{array}$ & High risk & Not possible to avoid risk given nature of intervention, and self-report. \\
\hline $\begin{array}{l}\text { Blinding of outcome as- } \\
\text { sessment (detection bias) } \\
\text { Side Effects }\end{array}$ & High risk & Not possible to avoid risk given nature of intervention, and self-report. \\
\hline $\begin{array}{l}\text { Incomplete outcome data } \\
\text { (attrition bias) } \\
\text { All outcomes }\end{array}$ & Low risk & 14 lost to follow-up, unclear which group they were part of, but less than $10 \%$. \\
\hline $\begin{array}{l}\text { Selective reporting (re- } \\
\text { porting bias) }\end{array}$ & Unclear risk & No protocol described. \\
\hline Other bias & Low risk & None identified, no baseline imbalance. \\
\hline
\end{tabular}

Slavin 1992

\section{Study characteristics}

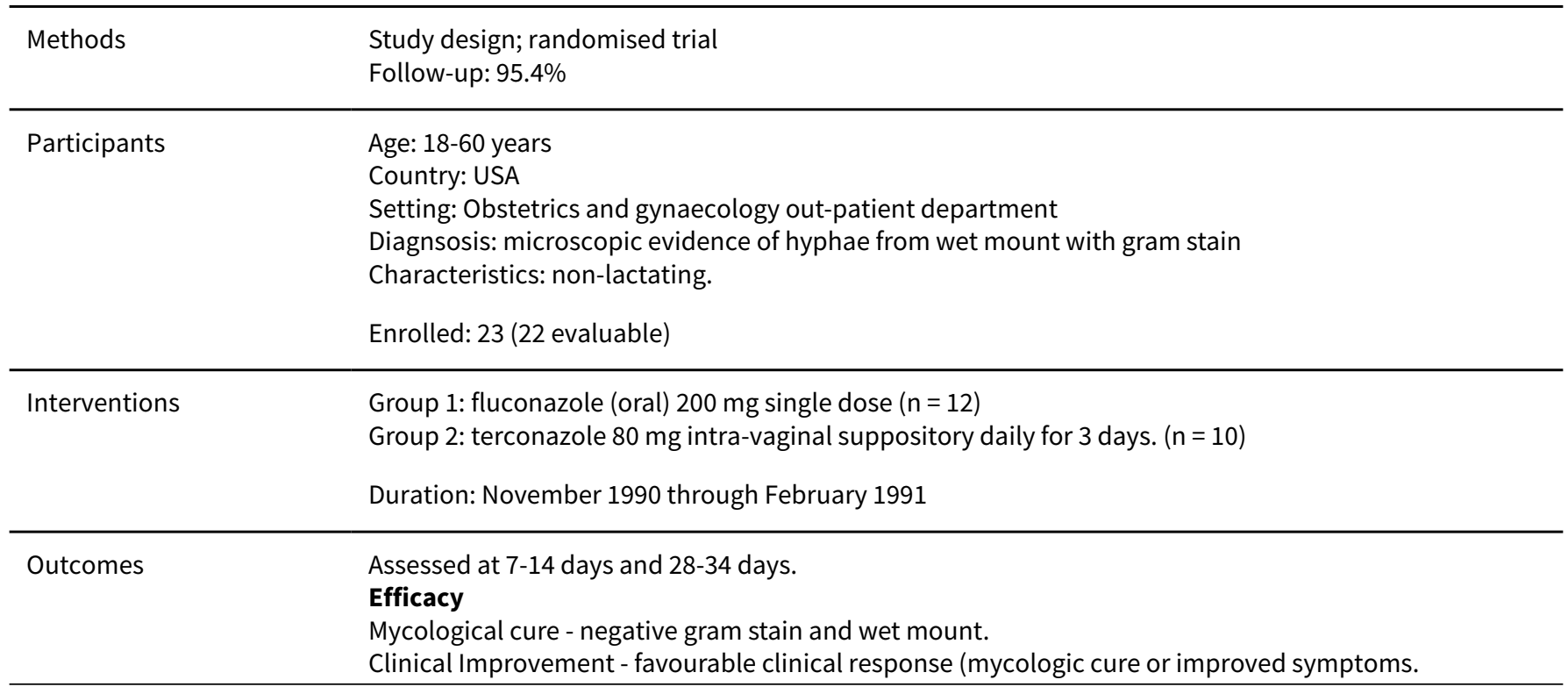

Oral versus intra-vaginal imidazole and triazole anti-fungal treatment of uncomplicated vulvovaginal candidiasis (thrush) (Review) 
Slavin 1992 (Continued)

Safety: quote: "No adverse drug events were noted"

Side effects: quote: "No adverse drug events were noted"

Treatment preference: reported (oral)

Time to first relief: reported - median and mean time to first relief

Costs: not assessed

Compliance check: yes - participant questioned at 7-14 day follow-up visit). Assessment of "medica-
tion-counts" at the early evaluation was considered $100 \%$ compliant.
Pharmaceutical industry support: not specified

\section{Risk of bias}

\begin{tabular}{lll}
\hline Bias & Authors' judgement & Support for judgement \\
\hline $\begin{array}{l}\text { Random sequence genera- } \\
\text { tion (selection bias) }\end{array}$ & Low risk & Random number table used. \\
\hline $\begin{array}{l}\text { Allocation concealment } \\
\text { (selection bias) }\end{array}$ & High risk & Not done. \\
\hline $\begin{array}{l}\text { Blinding of participants } \\
\text { and personnel (perfor- } \\
\text { mance bias) }\end{array}$ & High risk & Not possible to avoid risk given nature of intervention. \\
All outcomes & & \\
\hline
\end{tabular}

\begin{tabular}{|c|c|c|}
\hline $\begin{array}{l}\text { Blinding of outcome as- } \\
\text { sessment (detection bias) } \\
\text { Time to First Relief }\end{array}$ & High risk & Not possible to avoid risk given nature of intervention, and self-report. \\
\hline $\begin{array}{l}\text { Blinding of outcome as- } \\
\text { sessment (detection bias) } \\
\text { Mycological Cure }\end{array}$ & Low risk & $\begin{array}{l}\text { Testing done by lab cultures, which are objective outcomes, not influenced by } \\
\text { blinding. }\end{array}$ \\
\hline
\end{tabular}

Mycological Cure

Blinding of outcome as- Low risk sessment (detection bias) Mycological Improvement

\begin{tabular}{lll}
\hline $\begin{array}{l}\text { Blinding of outcome as- } \\
\text { sessment (detection bias) } \\
\text { Clinical Cure }\end{array}$ & High risk & \\
\hline $\begin{array}{l}\text { Blinding of outcome as- } \\
\text { sessment (detection bias) } \\
\text { Clinical Improvement }\end{array}$ & High risk & Self-report. \\
\hline
\end{tabular}

Testing done by lab cultures, which are objective outcomes, not influenced by blinding.

\begin{tabular}{lll}
\hline $\begin{array}{l}\text { Blinding of outcome as- } \\
\text { sessment (detection bias) } \\
\text { Side Effects }\end{array}$ & High risk & Self-report. \\
\hline $\begin{array}{l}\text { Incomplete outcome data } \\
\begin{array}{l}\text { (attrition bias) } \\
\text { All outcomes }\end{array}\end{array}$ & Low risk & No participants lost to follow-up \\
\hline $\begin{array}{l}\text { Selective reporting (re- } \\
\text { porting bias) }\end{array}$ & Unclear risk & No protocol described \\
\hline
\end{tabular}


Slavin 1992 (Continued)
Other bias
High risk
Baseline data imbalances reported

Sobel 1995

\section{Study characteristics}

\begin{tabular}{ll}
\hline Methods & Study design: randomised trial \\
& Follow-up: $93.8 \%$ \\
\hline Participants & Age: $17-64$ years \\
& Country: USA \\
& Setting: multi-centre (12 centres across the USA); type of setting not specified \\
& Diagnosis: $\mathrm{KOH}$, mycological culture and clinical symptoms. \\
& Characteristics: non-lactating \\
& Enrolled: 429 (358 evaluable)
\end{tabular}

Interventions

Group 1: fluconazole (oral) $150 \mathrm{mg}$ single dose $(n=218$ )

Group 2: clotrimazole vaginal tablets (one tablet, strength not stated) for 7 days $(n=214)$

Duration: not specified

\begin{tabular}{|c|c|}
\hline \multirow[t]{8}{*}{ Outcomes } & $\begin{array}{l}\text { Assessed at } 14 \text { and } 35 \text { days. } \\
\text { Efficacy }\end{array}$ \\
\hline & Mycological cure - no mycological colonisation \\
\hline & Clinical cure - absence of signs and symptoms of vaginitis. \\
\hline & Safety: no patient discontinued therapy \\
\hline & Side effects: participant reported side effects \\
\hline & Treatment preference: not assessed \\
\hline & Time to first relief: not assessed \\
\hline & Costs: not assessed \\
\hline Notes & $\begin{array}{l}\text { Compliance check: done - participant history and pill count. Quote: "No patient discontinued therapy"; } \\
100 \% \text { compliance. } \\
\text { Pharmaceutical industry support: yes } \\
\text { Participants had acute or recurrent vaginal candidiasis. Only the results for acute cases are presented }\end{array}$ \\
\hline
\end{tabular}

\section{Risk of bias}

\begin{tabular}{lll}
\hline Bias & Authors' judgement & Support for judgement \\
\hline $\begin{array}{l}\text { Random sequence genera- } \\
\text { tion (selection bias) }\end{array}$ & Unclear risk & No description provided. \\
\hline $\begin{array}{l}\text { Allocation concealment } \\
\text { (selection bias) }\end{array}$ & Unclear risk & No description provided. \\
\hline $\begin{array}{l}\text { Blinding of participants } \\
\text { and personnel (perfor- } \\
\text { mance bias) }\end{array}$ & High risk & Not possible to avoid risk given nature of intervention. \\
All outcomes & \\
\hline
\end{tabular}


Sobel 1995 (Continued)

Blinding of outcome as- High risk Not possible to avoid risk given nature of intervention, and self-report. sessment (detection bias)

Time to First Relief

\begin{tabular}{|c|c|c|}
\hline $\begin{array}{l}\text { Blinding of outcome as- } \\
\text { sessment (detection bias) } \\
\text { Mycological Cure }\end{array}$ & Low risk & $\begin{array}{l}\text { Testing done by lab cultures, which are objective outcomes, not influenced by } \\
\text { blinding. }\end{array}$ \\
\hline $\begin{array}{l}\text { Blinding of outcome as- } \\
\text { sessment (detection bias) } \\
\text { Mycological Improvement }\end{array}$ & Low risk & $\begin{array}{l}\text { Testing done by lab cultures, which are objective outcomes, not influenced by } \\
\text { blinding. }\end{array}$ \\
\hline $\begin{array}{l}\text { Blinding of outcome as- } \\
\text { sessment (detection bias) } \\
\text { Clinical Cure }\end{array}$ & High risk & Not possible to avoid risk given nature of intervention, and self-report. \\
\hline $\begin{array}{l}\text { Blinding of outcome as- } \\
\text { sessment (detection bias) } \\
\text { Clinical Improvement }\end{array}$ & High risk & Not possible to avoid risk given nature of intervention, and self-report. \\
\hline $\begin{array}{l}\text { Blinding of outcome as- } \\
\text { sessment (detection bias) } \\
\text { Side Effects }\end{array}$ & High risk & Not possible to avoid risk given nature of intervention, and self-report. \\
\hline $\begin{array}{l}\text { Incomplete outcome data } \\
\text { (attrition bias) } \\
\text { All outcomes }\end{array}$ & Low risk & Less than $10 \%$ dropout, roughly equal in both groups \\
\hline $\begin{array}{l}\text { Selective reporting (re- } \\
\text { porting bias) }\end{array}$ & Unclear risk & No protocol described \\
\hline Other bias & Low risk & Baseline data comparable. \\
\hline
\end{tabular}

\section{Stein 1991}

\section{Study characteristics}

\begin{tabular}{ll}
\hline Methods & $\begin{array}{l}\text { Study design: randomised trial } \\
\text { Follow-up: } 93.0 \%\end{array}$ \\
\hline Participants & $\begin{array}{l}\text { Age: } 18-65 \text { years } \\
\text { Country: USA } \\
\text { Setting: multi-centre; Primary Care Clinics } \\
\text { Diagnosis: visual examination, KOH and mycological culture } \\
\text { Enrolled: } 227 \text { (214 evaluable) }\end{array}$ \\
\hline Interventions & $\begin{array}{l}\text { Group 1: fluconazole (oral) } 50 \text { mg for } 3 \text { days }(\mathrm{n}=111) \\
\text { Group 2: clotrimazole intra-vaginal tablets } 200 \text { mg for } 3 \text { days. }(\mathrm{n}=116)\end{array}$ \\
Duration: not specified \\
\hline Outcomes & $\begin{array}{l}\text { Assessed at 7-10 days and 30-35 days. } \\
\text { Efficacy } \\
\text { Mycological cure - absence of candida species } \\
\text { Clinical cure - complete resolution of signs and symptoms }\end{array}$
\end{tabular}


Stein 1991 (Continued)

Safety: reported - quote: "One patient discontinued treatment after she developed diarrhea while re-

ceiving fluconazole"

Side effects: participant reported side effects

Treatment preference: not reported.

Time to first relief: not assessed

Costs: not assessed

\begin{tabular}{ll}
\hline Notes & Compliance check: not specified \\
& Pharmaceutical industry support: yes - Pfizer Central Research, Groton,CT.
\end{tabular}

\section{Risk of bias}

\begin{tabular}{lll}
\hline Bias & Authors' judgement & Support for judgement \\
\hline $\begin{array}{l}\text { Random sequence genera- } \\
\text { tion (selection bias) }\end{array}$ & Low risk & Predetermined code, likely random \\
\hline $\begin{array}{l}\text { Allocation concealment } \\
\text { (selection bias) }\end{array}$ & Unclear risk & No description provided. \\
\hline $\begin{array}{l}\text { Blinding of participants } \\
\begin{array}{l}\text { and personnel (perfor- } \\
\text { mance bias) }\end{array}\end{array}$ & High risk & Not possible to avoid risk given nature of intervention \\
All outcomes & \\
\hline
\end{tabular}

\begin{tabular}{|c|c|c|}
\hline $\begin{array}{l}\text { Blinding of outcome as- } \\
\text { sessment (detection bias) } \\
\text { Time to First Relief }\end{array}$ & High risk & Not possible to avoid risk given nature of intervention. \\
\hline $\begin{array}{l}\text { Blinding of outcome as- } \\
\text { sessment (detection bias) } \\
\text { Mycological Cure }\end{array}$ & Low risk & $\begin{array}{l}\text { Testing done by lab cultures, which are objective outcomes, not influenced by } \\
\text { blinding. }\end{array}$ \\
\hline
\end{tabular}

\begin{tabular}{lll}
\hline $\begin{array}{l}\text { Blinding of outcome as- } \\
\text { sessment (detection bias) } \\
\text { Mycological Improvement }\end{array}$ & Low risk & $\begin{array}{l}\text { Testing done by lab cultures, which are objective outcomes, not influenced by } \\
\text { blinding. }\end{array}$ \\
\hline $\begin{array}{l}\text { Blinding of outcome as- } \\
\text { sessment (detection bias) } \\
\text { Clinical Cure }\end{array}$ & High risk & Not possible to avoid risk given nature of intervention, and self-report. \\
\hline
\end{tabular}

\begin{tabular}{|c|c|c|}
\hline $\begin{array}{l}\text { Blinding of outcome as- } \\
\text { sessment (detection bias) } \\
\text { Clinical Improvement }\end{array}$ & High risk & Not possible to avoid risk given nature of intervention, and self-report. \\
\hline $\begin{array}{l}\text { Blinding of outcome as- } \\
\text { sessment (detection bias) } \\
\text { Side Effects }\end{array}$ & High risk & Not possible to avoid risk given nature of intervention, and self-report. \\
\hline $\begin{array}{l}\text { Incomplete outcome data } \\
\text { (attrition bias) } \\
\text { All outcomes }\end{array}$ & Low risk & Five of 95 lost to follow-up \\
\hline
\end{tabular}

Selective reporting (re- $\quad$ Unclear risk No protocol described.
porting bias)

Other bias Low risk Groups comparable at baseline.




\section{Study characteristics}

\begin{tabular}{|c|c|}
\hline Methods & $\begin{array}{l}\text { Study design: randomised trial (three arm) } \\
\text { Follow-up: } 94.7 \% \text { follow-up at first evaluation time point and } 63.2 \% \text { follow-up at second evaluation } \\
\text { time point }\end{array}$ \\
\hline Participants & $\begin{array}{l}\text { Age: } 18 \text { years and over } \\
\text { Country: USA } \\
\text { Setting: not specified } \\
\text { Diagnosis: KOH and clinical symptoms and mycological culture. } \\
\text { Enrolled: } 95 \text { ( } 90 \text { evaluable) }\end{array}$ \\
\hline Interventions & $\begin{array}{l}\text { Group 1: itraconazole (oral) } 200 \mathrm{mg} \text { for } 3 \text { days }(n=50 \\
\text { Group 2: clotrimazole vaginal tablets } 200 \mathrm{mg} \text { for } 3 \text { days }(n=23) \\
\text { Group 3: placebo: } n=22 \\
\text { Duration: not specified }\end{array}$ \\
\hline Outcomes & $\begin{array}{l}\text { Assessed at } 1 \text { and } 4 \text { weeks. } \\
\text { Efficacy } \\
\text { Mycological cure - absence of Candida species } \\
\text { Clinical cure - complete resolution of signs and symptoms } \\
\text { Safety: quote: "No patients enrolled in this study discontinued treatment because of an adverse event" } \\
\text { Side effects: reported } \\
\text { Treatment preference: reported. } \\
\text { Time to first relief: not assessed } \\
\text { Costs: not assessed }\end{array}$ \\
\hline
\end{tabular}

Notes Compliance check: not reported

Pharmaceutical industry support: yes - Research Foundation, Piscataway, N.J.

\section{Risk of bias}

\begin{tabular}{lll}
\hline Bias & Authors' judgement & Support for judgement \\
\hline $\begin{array}{l}\text { Random sequence genera- } \\
\text { tion (selection bias) }\end{array}$ & Unclear risk & No description provided. \\
\hline $\begin{array}{l}\text { Allocation concealment } \\
\text { (selection bias) }\end{array}$ & Unclear risk & No description provided. \\
\hline $\begin{array}{l}\text { Blinding of participants } \\
\begin{array}{l}\text { and personnel (perfor- } \\
\text { mance bias) }\end{array}\end{array}$ & High risk & Not possible to avoid risk given nature of intervention. \\
$\begin{array}{l}\text { All outcomes } \\
\text { Blinding of outcome as- } \\
\text { sessment (detection bias) } \\
\text { Time to First Relief }\end{array}$ & High risk & Not possible to avoid risk given nature of intervention, and self-report. \\
\hline
\end{tabular}


Stein 1993 (Continued)

\begin{tabular}{|c|c|c|}
\hline $\begin{array}{l}\text { Blinding of outcome as- } \\
\text { sessment (detection bias) } \\
\text { Mycological Cure }\end{array}$ & Low risk & $\begin{array}{l}\text { Testing done by lab cultures, which are objective outcomes, not influenced by } \\
\text { blinding. }\end{array}$ \\
\hline
\end{tabular}

\begin{tabular}{|c|c|c|}
\hline $\begin{array}{l}\text { Blinding of outcome as- } \\
\text { sessment (detection bias) } \\
\text { Mycological Improvement }\end{array}$ & Low risk & $\begin{array}{l}\text { Testing done by lab cultures, which are objective outcomes, not influenced by } \\
\text { blinding. }\end{array}$ \\
\hline $\begin{array}{l}\text { Blinding of outcome as- } \\
\text { sessment (detection bias) } \\
\text { Clinical Cure }\end{array}$ & High risk & Not possible to avoid risk given nature of intervention, and self-report. \\
\hline $\begin{array}{l}\text { Blinding of outcome as- } \\
\text { sessment (detection bias) } \\
\text { Clinical Improvement }\end{array}$ & High risk & Not possible to avoid risk given nature of intervention, and self-report. \\
\hline $\begin{array}{l}\text { Blinding of outcome as- } \\
\text { sessment (detection bias) } \\
\text { Side Effects }\end{array}$ & High risk & Not possible to avoid risk given nature of intervention, and self-report. \\
\hline $\begin{array}{l}\text { Incomplete outcome data } \\
\text { (attrition bias) } \\
\text { All outcomes }\end{array}$ & High risk & Overall, $60 / 95$ or $63.2 \%$ of participants were assessed at four week follow-up. \\
\hline $\begin{array}{l}\text { Selective reporting (re- } \\
\text { porting bias) }\end{array}$ & Unclear risk & No protocol described. \\
\hline Other bias & Low risk & Baseline data comparable. \\
\hline
\end{tabular}

Timonen 1992a

\section{Study characteristics}

\begin{tabular}{|c|c|}
\hline Methods & $\begin{array}{l}\text { Study design: randomised trial (multi-centre) } \\
\text { Follow-up: not calculable }\end{array}$ \\
\hline Participants & $\begin{array}{l}\text { Age: } 18 \text { years and over } \\
\text { Country: Finland } \\
\text { Setting: non-specified multi-centre setting - possibly gynaecologist/physician office/practice } \\
\text { Diagnosis: mycological culture and clinical symptoms } \\
\text { Enrolled: } 125 \text { ( } 63 \text { fluconazole and } 62 \text { miconazole) } 20 \text { patients were negative for yeast culture after ran- } \\
\text { domisation and removed) } 105 \text { evaluable }\end{array}$ \\
\hline Interventions & $\begin{array}{l}\text { Group 1: fluconazole (oral) } 150 \mathrm{mg} \text { single dose }(n=56) \\
\text { Group 2: miconazole } 400 \mathrm{mg} \text { pessary for } 3 \text { days }(n=49) \\
\text { Duration: not specified }\end{array}$ \\
\hline Outcomes & $\begin{array}{l}\text { Assessed at } 1 \text { week and } 1 \text { month } \\
\text { Efficacy } \\
\text { Mycologicalcure - negative yeast culture } \\
\text { Clinical cure - asymptomatic } \\
\text { Safety: quote: "One patient discontinued the treatment because of a severe burning sensation in the } \\
\text { vagina" - miconazole group }\end{array}$ \\
\hline
\end{tabular}


Timonen 1992a (Continued)

Side effects: reported

Treatment preference: reported

Time to first relief: not assessed

Costs: not assessed

\begin{tabular}{l} 
Notes $\begin{array}{l}\text { Compliance check: not reported } \\
\text { Pharmaceutical industry support: not reported } \\
\text { Results calculated from percentages quoted by authors. Five itraconazole and eight econazole partic- } \\
\text { ipants had chronic vaginal candidiasis (i.e. } 3 \text { or more episodes in previous } 12 \text { months) - results not re- } \\
\text { ported separately }\end{array}$ \\
\hline
\end{tabular}

\section{Risk of bias}

\begin{tabular}{|c|c|c|}
\hline Bias & Authors' judgement & Support for judgement \\
\hline $\begin{array}{l}\text { Random sequence genera- } \\
\text { tion (selection bias) }\end{array}$ & Unclear risk & No description provided. \\
\hline $\begin{array}{l}\text { Allocation concealment } \\
\text { (selection bias) }\end{array}$ & Unclear risk & No description provided. \\
\hline $\begin{array}{l}\text { Blinding of participants } \\
\text { and personnel (perfor- } \\
\text { mance bias) } \\
\text { All outcomes }\end{array}$ & High risk & Not possible to avoid risk given nature of intervention. \\
\hline $\begin{array}{l}\text { Blinding of outcome as- } \\
\text { sessment (detection bias) } \\
\text { Time to First Relief }\end{array}$ & High risk & Not possible to avoid risk given nature of intervention, and self-report. \\
\hline $\begin{array}{l}\text { Blinding of outcome as- } \\
\text { sessment (detection bias) } \\
\text { Mycological Cure }\end{array}$ & Low risk & $\begin{array}{l}\text { Testing done by lab cultures, which are objective outcomes, not influenced by } \\
\text { blinding. }\end{array}$ \\
\hline $\begin{array}{l}\text { Blinding of outcome as- } \\
\text { sessment (detection bias) } \\
\text { Mycological Improvement }\end{array}$ & Low risk & $\begin{array}{l}\text { Testing done by lab cultures, which are objective outcomes, not influenced by } \\
\text { blinding. }\end{array}$ \\
\hline $\begin{array}{l}\text { Blinding of outcome as- } \\
\text { sessment (detection bias) } \\
\text { Clinical Cure }\end{array}$ & High risk & Not possible to avoid risk given nature of intervention, and self-report. \\
\hline $\begin{array}{l}\text { Blinding of outcome as- } \\
\text { sessment (detection bias) } \\
\text { Clinical Improvement }\end{array}$ & High risk & Not possible to avoid risk given nature of intervention, and self-report. \\
\hline $\begin{array}{l}\text { Blinding of outcome as- } \\
\text { sessment (detection bias) } \\
\text { Side Effects }\end{array}$ & High risk & Not possible to avoid risk given nature of intervention, and self-report. \\
\hline $\begin{array}{l}\text { Incomplete outcome data } \\
\text { (attrition bias) } \\
\text { All outcomes }\end{array}$ & Unclear risk & Not calculable. \\
\hline
\end{tabular}


Timonen 1992a (Continued)

Selective reporting (re- Unclear risk $\quad$ No protocol described.
porting bias)

Other bias Low risk Groups comparable at baseline.

Timonen 1992b

\section{Study characteristics}

\begin{tabular}{|c|c|c|}
\hline Methods & \multicolumn{2}{|c|}{$\begin{array}{l}\text { Study design: randomised trial } \\
\text { Follow-up: not calculable }\end{array}$} \\
\hline Participants & \multicolumn{2}{|c|}{$\begin{array}{l}\text { Age: } 20 \text { to } 58 \text { years } \\
\text { Country: Finland } \\
\text { Setting: multi-centre; three outpatient sites (not specified) } \\
\text { Diagnosis: mycological culture }\end{array}$} \\
\hline Interventions & \multicolumn{2}{|c|}{$\begin{array}{l}\text { Group 1: itraconazole } 200 \mathrm{mg} \text { for } 3 \text { days. }(n=40) \\
\text { Group 2: econazole } 150 \mathrm{mg} \text { for } 3 \text { days. }(n=41) \\
\text { Duration: Two years (not specified) }\end{array}$} \\
\hline Outcomes & $\begin{array}{l}\text { Assessed at } 1 \text { and } 2 \text { we } \\
\text { Efficacy } \\
\text { Mycological cure - neg } \\
\text { Clinical Improvement } \\
\text { Safety: quote: "None c } \\
\text { Side effects: reported } \\
\text { Treatment preference } \\
\text { Time to first relief: rep } \\
\text { treatment } \\
\text { Costs: not assessed }\end{array}$ & $\begin{array}{l}\text { tive gram stain and wet mount. } \\
\text { favourable clinical response (mycologic cure or improved symptoms. } \\
\text { the patients discontinued treatment because of an adverse event" } \\
\text { reported } \\
\text { rted - proportion of patients reporting alleviation of symptoms each day post- }\end{array}$ \\
\hline Notes & \multicolumn{2}{|c|}{$\begin{array}{l}\text { Compliance check: not reported } \\
\text { Pharmaceutical industry support: yes - Orion Pharmaceutica, Espoo, Finland }\end{array}$} \\
\hline \multicolumn{3}{|l|}{ Risk of bias } \\
\hline Bias & Authors' judgement & Support for judgement \\
\hline $\begin{array}{l}\text { Random sequence genera- } \\
\text { tion (selection bias) }\end{array}$ & Unclear risk & No description provided. \\
\hline $\begin{array}{l}\text { Allocation concealment } \\
\text { (selection bias) }\end{array}$ & Unclear risk & No description provided. \\
\hline $\begin{array}{l}\text { Blinding of participants } \\
\text { and personnel (perfor- } \\
\text { mance bias) } \\
\text { All outcomes }\end{array}$ & Low risk & Double-blind trial (double-dummy). \\
\hline
\end{tabular}


Timonen 1992b (Continued)

Blinding of outcome as- High risk Not possible to avoid risk given nature of intervention, and self-report. sessment (detection bias)

Time to First Relief

\begin{tabular}{|c|c|c|}
\hline $\begin{array}{l}\text { Blinding of outcome as- } \\
\text { sessment (detection bias) } \\
\text { Mycological Cure }\end{array}$ & Low risk & $\begin{array}{l}\text { Testing done by lab cultures, which are objective outcomes, not influenced by } \\
\text { blinding. }\end{array}$ \\
\hline $\begin{array}{l}\text { Blinding of outcome as- } \\
\text { sessment (detection bias) } \\
\text { Mycological Improvement }\end{array}$ & Low risk & $\begin{array}{l}\text { Testing done by lab cultures, which are objective outcomes, not influenced by } \\
\text { blinding. }\end{array}$ \\
\hline $\begin{array}{l}\text { Blinding of outcome as- } \\
\text { sessment (detection bias) } \\
\text { Clinical Cure }\end{array}$ & High risk & Self-report. \\
\hline $\begin{array}{l}\text { Blinding of outcome as- } \\
\text { sessment (detection bias) } \\
\text { Clinical Improvement }\end{array}$ & High risk & Self-report. \\
\hline $\begin{array}{l}\text { Blinding of outcome as- } \\
\text { sessment (detection bias) } \\
\text { Side Effects }\end{array}$ & High risk & Self-report. \\
\hline $\begin{array}{l}\text { Incomplete outcome data } \\
\text { (attrition bias) } \\
\text { All outcomes }\end{array}$ & Unclear risk & Not calculable. \\
\hline $\begin{array}{l}\text { Selective reporting (re- } \\
\text { porting bias) }\end{array}$ & Unclear risk & No protocol described \\
\hline Other bias & Low risk & Baseline data was comparable. \\
\hline
\end{tabular}

\section{Tobin 1992}

\section{Study characteristics}

\begin{tabular}{|c|c|}
\hline Methods & $\begin{array}{l}\text { Study design: randomised trial (multi-centre) } \\
\text { Follow-up: } 68.7 \%\end{array}$ \\
\hline Participants & $\begin{array}{l}\text { Age: } 18 \text { years and over } \\
\text { Country: UK } \\
\text { Setting: Genito-urinary medicine clinics in } 17 \text { hospitals across UK } \\
\text { Diagnosis: visual examination, mycological culture and clinical symptoms (vulvitis, vaginitis). } \\
\text { Enrolled: } 262 \text { ( } 214 \text { evaluable) }\end{array}$ \\
\hline Interventions & $\begin{array}{l}\text { Group 1: itraconazole } 200 \mathrm{mg} \text { two times a day for one day }(n=109) \\
\text { Group 2: clotrimazole } 500 \mathrm{mg} \text { - Single dose }(n=105) \\
\text { Duration: not specified }\end{array}$ \\
\hline
\end{tabular}


Tobin 1992 (Continued)

Mycological cure: negative culture for Candida species.

Safety: no withdrawals due to adverse events

Side effects: not reported

Treatment preference: reported

Time to first relief: reported - mean time to first relief

Costs: not reported

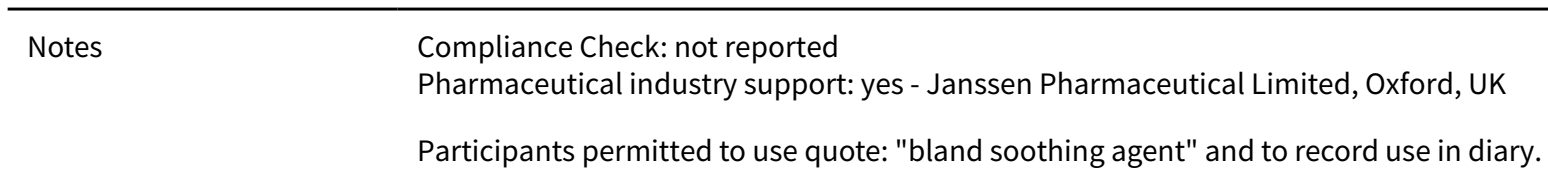

\section{Risk of bias}

\begin{tabular}{lll}
\hline Bias & Authors' judgement & Support for judgement \\
\hline $\begin{array}{l}\text { Random sequence genera- } \\
\text { tion (selection bias) }\end{array}$ & Unclear risk & No description provided \\
\hline $\begin{array}{l}\text { Allocation concealment } \\
\text { (selection bias) }\end{array}$ & Unclear risk & No description provided \\
\hline
\end{tabular}

Blinding of participants High risk Not possible to avoid risk given nature of intervention.
and personnel (perfor-
mance bias)
All outcomes

\begin{tabular}{lll}
\hline $\begin{array}{l}\text { Blinding of outcome as- } \\
\text { sessment (detection bias) } \\
\text { Time to First Relief }\end{array}$ & High risk & Not possible to avoid risk given nature of intervention, and self-report. \\
\hline $\begin{array}{l}\text { Blinding of outcome as- } \\
\text { sessment (detection bias) } \\
\text { Mycological Cure }\end{array}$ & Low risk & $\begin{array}{l}\text { Testing done by lab cultures, which are objective outcomes, not influenced by } \\
\text { blinding. }\end{array}$ \\
\hline
\end{tabular}

\begin{tabular}{|c|c|c|}
\hline $\begin{array}{l}\text { Blinding of outcome as- } \\
\text { sessment (detection bias) } \\
\text { Mycological Improvement }\end{array}$ & Low risk & $\begin{array}{l}\text { Testing done by lab cultures, which are objective outcomes, not influenced by } \\
\text { blinding. }\end{array}$ \\
\hline
\end{tabular}

\begin{tabular}{|c|c|c|}
\hline $\begin{array}{l}\text { Blinding of outcome as- } \\
\text { sessment (detection bias) } \\
\text { Clinical Cure }\end{array}$ & High risk & Not possible to avoid risk given nature of intervention, and self-report. \\
\hline $\begin{array}{l}\text { Blinding of outcome as- } \\
\text { sessment (detection bias) } \\
\text { Clinical Improvement }\end{array}$ & High risk & Not possible to avoid risk given nature of intervention, and self-report. \\
\hline $\begin{array}{l}\text { Blinding of outcome as- } \\
\text { sessment (detection bias) } \\
\text { Side Effects }\end{array}$ & High risk & Not possible to avoid risk given nature of intervention, and self-report. \\
\hline $\begin{array}{l}\text { Incomplete outcome data } \\
\text { (attrition bias) } \\
\text { All outcomes }\end{array}$ & High risk & Twenty per cent lost to follow-up. \\
\hline
\end{tabular}


Tobin 1992 (Continued)

Selective reporting (re- $\quad$ Unclear risk $\quad$ No protocol described
porting bias)

Other bias Unclear risk Baseline data not reported.

Van Heusden 1990

\section{Study characteristics}

\begin{tabular}{|c|c|c|}
\hline Methods & \multicolumn{2}{|c|}{$\begin{array}{l}\text { Study design: randomised trial (multi-centre) } \\
\text { Follow-up: } 93.9 \%\end{array}$} \\
\hline Participants & \multicolumn{2}{|c|}{$\begin{array}{l}\text { Age: } 18-60 \text { years } \\
\text { Country: the Netherlands } \\
\text { Setting: Out-patients - multi-centre department or centres not specified } \\
\text { Diagnosis: mycological culture and clinical symptoms } \\
\text { Characteristics: non-lactating }\end{array}$} \\
\hline Interventions & \multicolumn{2}{|c|}{$\begin{array}{l}\text { Group 1: fluconazole (oral) } 150 \mathrm{mg} \text { single dose }(n=49) \\
\text { Group 2: Miconazole } 1200 \mathrm{mg} \text { intra-vaginal single dose }(n=50) \\
\text { Duration: Not specified }\end{array}$} \\
\hline Outcomes & $\begin{array}{l}\text { Assessed at } 6 \text { - } 10 \text { days } \\
\text { Efficacy } \\
\text { Mycological cure - con } \\
\text { Clinical cure - physicia } \\
\text { Safety: no withdrawal } \\
\text { Side effects: participa } \\
\text { Treatment preference } \\
\text { Time to first relief: not } \\
\text { Costs: not reported }\end{array}$ & $\begin{array}{l}\text { hort-term) and 22-60 days (long-term) follow-up. } \\
\text { lete absence of Candida species at follow-up. } \\
\text { subjective global assessment. } \\
\text { due to side effects reported } \\
\text { treported side effects. } \\
\text { reported } \\
\text { ssessed }\end{array}$ \\
\hline Notes & \multicolumn{2}{|c|}{$\begin{array}{l}\text { Compliance check: not reported } \\
\text { Pharmaceutical industry support: not specified }\end{array}$} \\
\hline \multicolumn{3}{|l|}{ Risk of bias } \\
\hline Bias & Authors' judgement & Support for judgement \\
\hline $\begin{array}{l}\text { Random sequence genera- } \\
\text { tion (selection bias) }\end{array}$ & Unclear risk & No description provided. \\
\hline $\begin{array}{l}\text { Allocation concealment } \\
\text { (selection bias) }\end{array}$ & Unclear risk & No description provided. \\
\hline $\begin{array}{l}\text { Blinding of participants } \\
\text { and personnel (perfor- } \\
\text { mance bias) } \\
\text { All outcomes }\end{array}$ & Low risk & Double-blind trial (double-dummy). \\
\hline
\end{tabular}


Van Heusden 1990 (Continued)
Blinding of outcome as-
High risk
Not possible to avoid risk given nature of intervention, and self-report. sessment (detection bias)

Time to First Relief

\begin{tabular}{|c|c|c|}
\hline $\begin{array}{l}\text { Blinding of outcome as- } \\
\text { sessment (detection bias) } \\
\text { Mycological Cure }\end{array}$ & Low risk & $\begin{array}{l}\text { Testing done by lab cultures, which are objective outcomes, not influenced by } \\
\text { blinding. }\end{array}$ \\
\hline $\begin{array}{l}\text { Blinding of outcome as- } \\
\text { sessment (detection bias) } \\
\text { Mycological Improvement }\end{array}$ & Low risk & $\begin{array}{l}\text { Testing done by lab cultures, which are objective outcomes, not influenced by } \\
\text { blinding. }\end{array}$ \\
\hline $\begin{array}{l}\text { Blinding of outcome as- } \\
\text { sessment (detection bias) } \\
\text { Clinical Cure }\end{array}$ & High risk & Self-report. \\
\hline $\begin{array}{l}\text { Blinding of outcome as- } \\
\text { sessment (detection bias) } \\
\text { Clinical Improvement }\end{array}$ & High risk & Self-report. \\
\hline $\begin{array}{l}\text { Blinding of outcome as- } \\
\text { sessment (detection bias) } \\
\text { Side Effects }\end{array}$ & High risk & Self-report. \\
\hline $\begin{array}{l}\text { Incomplete outcome data } \\
\text { (attrition bias) } \\
\text { All outcomes }\end{array}$ & Low risk & Small number but all in one group, $<10 \%$ \\
\hline $\begin{array}{l}\text { Selective reporting (re- } \\
\text { porting bias) }\end{array}$ & Unclear risk & No protocol described. \\
\hline Other bias & Low risk & Comparable groups at baseline. \\
\hline
\end{tabular}

Van Heusden 1994

\section{Study characteristics}

\begin{tabular}{ll}
\hline Methods & $\begin{array}{l}\text { Study design: randomised trial (multi-centre) } \\
\text { Follow-up: not-calculable }\end{array}$ \\
\hline Participants & $\begin{array}{l}\text { Age: } 18-65 \text { years } \\
\text { Country: the Netherlands } \\
\text { Setting: Obstetrics and Gynaecology Out-Patient Department and General Practices } \\
\text { Diagnosis: mycological culture and clinical symptoms } \\
\text { Characteristics: non-lactating }\end{array}$ \\
Enrolled: 741 (693 evaluable) \\
\hline Interventions & $\begin{array}{l}\text { Group 1: fluconazole (oral) } 150 \text { mg single dose }(\mathrm{n}=\text { not clearly reported) } \\
\text { Group 2: clotrimazole intra-vaginal tablets } 500 \mathrm{mg} \text { single dose }(\mathrm{n}=\text { not clearly reported) }\end{array}$ \\
Duration: Not specified
\end{tabular}

Outcomes

Assessed at 7 and 28 days

Efficacy

Mycological cure: complete absence of Candida species 
Clinical cure: signs and symptoms scored by patient and overall efficacy rated by both physician and patient

Safety: No withdrawals due to side effects reported

Side effects: reported.

Treatment preference: reported

Time to first relief: not reported

Costs: not reported

$\begin{array}{ll}\text { Notes } & \text { Compliance check: not reported } \\ & \text { Pharmaceutical industry support: not specified } \\ & \text { Results calculated from percentages quoted by authors }\end{array}$

\section{Risk of bias}

\begin{tabular}{lll}
\hline Bias & Authors' judgement & Support for judgement \\
\hline $\begin{array}{l}\text { Random sequence genera- } \\
\text { tion (selection bias) }\end{array}$ & Low risk & Compute- generated list, likely random. \\
\hline $\begin{array}{l}\text { Allocation concealment } \\
\text { (selection bias) }\end{array}$ & Unclear risk & No description provided. \\
\hline $\begin{array}{l}\text { Blinding of participants } \\
\text { and personnel (perfor- } \\
\text { mance bias) } \\
\text { All outcomes }\end{array}$ & High risk & Not possible to avoid risk given nature of intervention. \\
\hline
\end{tabular}

\begin{tabular}{|c|c|c|}
\hline $\begin{array}{l}\text { Blinding of outcome as- } \\
\text { sessment (detection bias) } \\
\text { Time to First Relief }\end{array}$ & High risk & Not possible to avoid risk given nature of intervention, and self-report. \\
\hline $\begin{array}{l}\text { Blinding of outcome as- } \\
\text { sessment (detection bias) } \\
\text { Mycological Cure }\end{array}$ & Low risk & $\begin{array}{l}\text { Testing done by lab cultures, which are objective outcomes, not influenced by } \\
\text { blinding. }\end{array}$ \\
\hline
\end{tabular}

Mycological Cure

Blinding of outcome as-
sessment (detection bias)
Mycological Improvement

\section{Low risk}

blinding.

Blinding of outcome as- High risk Not possible to avoid risk given nature of intervention, and self-report. sessment (detection bias) Clinical Cure

\begin{tabular}{|c|c|c|}
\hline $\begin{array}{l}\text { Blinding of outcome as- } \\
\text { sessment (detection bias) } \\
\text { Clinical Improvement }\end{array}$ & High risk & Not possible to avoid risk given nature of intervention, and self-report. \\
\hline $\begin{array}{l}\text { Blinding of outcome as- } \\
\text { sessment (detection bias) } \\
\text { Side Effects }\end{array}$ & High risk & Not possible to avoid risk given nature of intervention, and self-report. \\
\hline $\begin{array}{l}\text { Incomplete outcome data } \\
\text { (attrition bias) } \\
\text { All outcomes }\end{array}$ & Low risk & Only $6.4 \%$ lost to follow-up. \\
\hline
\end{tabular}


Van Heusden 1994 (Continued)

Selective reporting (re- Unclear risk $\quad$ No protocol described.
porting bias)

Other bias Unclear risk Baseline data not reported.

Woolley 1995

\section{Study characteristics}

\begin{tabular}{|c|c|}
\hline Methods & $\begin{array}{l}\text { Study design: randomised trial } \\
\text { Follow-up: } 100 \%\end{array}$ \\
\hline Participants & $\begin{array}{l}\text { Age: } 16-53 \text { years } \\
\text { Country: UK } \\
\text { Setting: Genito-urinary Medicine Clinic } \\
\text { Diagnosis: mycological and/or microscopic. } \\
\text { Enrolled: } 229\end{array}$ \\
\hline Interventions & $\begin{array}{l}\text { Group 1: clotrimazole pessary } 500 \mathrm{mg} \text { (single dose) and 1\% cream. }(\mathrm{n}=82) \\
\text { Group 2: fluconazole (oral) } 150 \mathrm{mg} \text { single dose }(\mathrm{n}=72) \\
\text { Group 3: itraconazole (oral) } 200 \mathrm{mg} \text { (single dose) }(\mathrm{n}=75) \\
\text { Duration: Not specified }\end{array}$ \\
\hline Outcomes & $\begin{array}{l}\text { Assessed at 7-10 days. } \\
\text { Efficacy } \\
\text { Mycological cure - negative culture and tests for Candida } \\
\text { Clinical cure - assessed by physician } \\
\text { Safety: not reported } \\
\text { Side effects: not reported } \\
\text { Treatment preference: not reported } \\
\text { Time to first relief: not reported } \\
\text { Costs: not reported }\end{array}$ \\
\hline Notes & $\begin{array}{l}\text { Compliance check: not reported } \\
\text { Pharmaceutical industry support: not specified }\end{array}$ \\
\hline
\end{tabular}

\section{Risk of bias}

\begin{tabular}{lll}
\hline Bias & Authors' judgement & Support for judgement \\
\hline $\begin{array}{l}\text { Random sequence genera- } \\
\text { tion (selection bias) }\end{array}$ & Unclear risk & No description provided. \\
\hline $\begin{array}{l}\text { Allocation concealment } \\
\text { (selection bias) }\end{array}$ & Unclear risk & No description provided. \\
\hline $\begin{array}{l}\text { Blinding of participants } \\
\text { and personnel (perfor- } \\
\text { mance bias) }\end{array}$ & High risk & not possible given nature of intervention \\
\end{tabular}


Woolley 1995 (Continued)

All outcomes

Blinding of outcome as-
sessment (detection bias) $\quad$ High risk Not possible to avoid risk given nature of intervention, and self-report.

sessment (detection bias)

Time to First Relief

\begin{tabular}{|c|c|c|}
\hline $\begin{array}{l}\text { Blinding of outcome as- } \\
\text { sessment (detection bias) } \\
\text { Mycological Cure }\end{array}$ & Low risk & $\begin{array}{l}\text { Testing done by lab cultures, which are objective outcomes, not influenced by } \\
\text { blinding. }\end{array}$ \\
\hline $\begin{array}{l}\text { Blinding of outcome as- } \\
\text { sessment (detection bias) } \\
\text { Mycological Improvement }\end{array}$ & Low risk & $\begin{array}{l}\text { Testing done by lab cultures, which are objective outcomes, not influenced by } \\
\text { blinding. }\end{array}$ \\
\hline $\begin{array}{l}\text { Blinding of outcome as- } \\
\text { sessment (detection bias) } \\
\text { Clinical Cure }\end{array}$ & High risk & Not possible to avoid risk given nature of intervention, and self-report. \\
\hline
\end{tabular}

\begin{tabular}{lll}
\hline Blinding of outcome as- & High risk & Not possible to avoid risk given nature of intervention, and self-report. \\
sessment (detection bias)
\end{tabular}

Clinical Improvement

$\begin{array}{lll}\text { Blinding of outcome as- } & \text { High risk } & \text { Not possible to avoid risk given nature of intervention, and self-report. } \\ \text { sessment (detection bias) }\end{array}$

sessment (detection bias)

Side Effects

Incomplete outcome data Low risk No participants lost to follow-up.
(attrition bias)

All outcomes

\begin{tabular}{lll}
\hline $\begin{array}{l}\text { Selective reporting (re- } \\
\text { porting bias) }\end{array}$ & Unclear risk & No protocol described. \\
\hline Other bias & Low risk & Baseline data comparable. \\
\hline
\end{tabular}

\section{Škerk V 2006}

\section{Study characteristics}

\begin{tabular}{ll}
\hline Methods & Study design: randomised trial \\
& Follow-up:uUnclear, insufficient data presented. \\
\hline Participants & Age: 18 - 45 years \\
& Country; Croatia \\
& Settings: General Practice (not specified) \\
& Diagnosis: visual examination, clinical symptoms, confirmed microscopically \\
& Characteristics: not specified \\
& Enrolled: 246 episodes (of thrush) 83 participants \\
\hline
\end{tabular}

Interventions

Group 1: fluconazole (oral) $150 \mathrm{mg}$ single dose ( $n=71$ episodes)

Group 2: clotrimazole (intra-vaginal) $200 \mathrm{mg}$ daily for 3 days ( $\mathrm{n}=55$ episodes) 
Škerk V 2006 (Continued)

Duration: June 1, 2006 until July 31, 2006,

Assessed up to 2 months following treatment allocation.
Efficacy
Clinical cure: successful treatment, recurrent VVC as reported by patients
Mycological cure: not reported
Safety: no withdrawals due to side effects reported
Side effects: reported: quote: "There were no side effects of the doctor trial" (per our translation)
Treatment preference: not assessed
Time to first relief: not assessed
Costs: not assessed

Notes

Compliance check: not specified

Pharmaceutical industry support: not specified

\section{Risk of bias}

\begin{tabular}{|c|c|c|}
\hline Bias & Authors' judgement & Support for judgement \\
\hline $\begin{array}{l}\text { Random sequence genera- } \\
\text { tion (selection bias) }\end{array}$ & Unclear risk & No description provided. \\
\hline $\begin{array}{l}\text { Allocation concealment } \\
\text { (selection bias) }\end{array}$ & Unclear risk & No description provided. \\
\hline $\begin{array}{l}\text { Blinding of participants } \\
\text { and personnel (perfor- } \\
\text { mance bias) } \\
\text { All outcomes }\end{array}$ & High risk & Not possible to avoid risk given nature of intervention. \\
\hline $\begin{array}{l}\text { Blinding of outcome as- } \\
\text { sessment (detection bias) } \\
\text { Time to First Relief }\end{array}$ & Unclear risk & Outcome not assessed. \\
\hline $\begin{array}{l}\text { Blinding of outcome as- } \\
\text { sessment (detection bias) } \\
\text { Mycological Cure }\end{array}$ & Unclear risk & Outcome not assessed. \\
\hline $\begin{array}{l}\text { Blinding of outcome as- } \\
\text { sessment (detection bias) } \\
\text { Mycological Improvement }\end{array}$ & Unclear risk & Outcome not assessed. \\
\hline $\begin{array}{l}\text { Blinding of outcome as- } \\
\text { sessment (detection bias) } \\
\text { Clinical Cure }\end{array}$ & Unclear risk & Not possible to avoid risk given nature of intervention, and self-report. \\
\hline $\begin{array}{l}\text { Blinding of outcome as- } \\
\text { sessment (detection bias) } \\
\text { Clinical Improvement }\end{array}$ & Unclear risk & Not possible to avoid risk given nature of intervention, and self-report. \\
\hline $\begin{array}{l}\text { Blinding of outcome as- } \\
\text { sessment (detection bias) } \\
\text { Side Effects }\end{array}$ & Unclear risk & Not possible to avoid risk given nature of intervention, and self-report. \\
\hline
\end{tabular}


Škerk V 2006 (Continued)
Incomplete outcome data
Unclear risk
Numbers in group not specified.
(attrition bias)

All outcomes

Selective reporting (re- $\quad$ Unclear risk $\quad$ No protocol described.
porting bias)

Other bias Unclear risk No data provided for baseline values. See table 1 for baseline imbalance.

ITT: intention-to-treat

O\&G OPD = Obstetrics and Gynaecology Out-Patient Department

$\mathrm{KOH}=$ potassium hydroxide

VVC: vulvovaginal candidiasis

Characteristics of excluded studies [ordered by study ID]

\begin{tabular}{ll}
\hline Study & Reason for exclusion \\
\hline EUCTR2005-001360-31-IT & $\begin{array}{l}\text { Contacted Abiogen Pharma July 12, 2018 and October 8, 2018 using online contact form to enquire } \\
\text { about the open treatment arm to determine eligibility. Study has been completed. Acknowledg- } \\
\text { ment of contact received only; no response to query received. Website: https://www.abiogen.it/en/ }\end{array}$ \\
\hline Fan 2015 & Did not meet inclusion criteria (involved women with complicated vulvovaginal candidiasis) \\
\hline Fong 1992 & Did not meet inclusion criteria (involved women with complicated vulvovaginal candidiasis) \\
\hline Herzog 1989 & Random allocation not specified. \\
\hline Li 2015 & Did not meet inclusion criteria (involved women with complicated vulvovaginal candidiasis). \\
\hline Lopez Olmos 1994 & Random allocation not specified. \\
\hline Mikamo 1998 & $\begin{array}{l}\text { The review authors believe that the some of the participants reported in this trial were reported in } \\
\text { a previous included trial Mikamo 1995). This trial has been excluded to avoid duplicate use of data. }\end{array}$ \\
\hline Wermeling 1992 & Abstract only - insufficient information provided. \\
\hline Zhou 2016 & Did not meet inclusion criteria (involved women with complicated vulvovaginal candidiasis). \\
\hline
\end{tabular}

DATA AND ANALYSES

\section{Comparison 1. Oral versus Intra-vaginal}

\begin{tabular}{lllll}
\hline Outcome or subgroup title & $\begin{array}{l}\text { No. of } \\
\text { studies }\end{array}$ & $\begin{array}{l}\text { No. of } \\
\text { partici- } \\
\text { pants }\end{array}$ & Statistical method & Effect size \\
\hline 1.1 Clinical cure (short term) & 13 & 1859 & Odds Ratio (M-H, Fixed, 95\% Cl) & $1.14[0.91,1.43]$ \\
\hline 1.1 .1 Fluconazole vs Clotrimazole & 6 & 809 & Odds Ratio (M-H, Fixed, 95\% Cl) & $1.13[0.81,1.58]$ \\
\hline
\end{tabular}

Oral versus intra-vaginal imidazole and triazole anti-fungal treatment of uncomplicated vulvovaginal candidiasis (thrush) (Review) 


\begin{tabular}{|c|c|c|c|c|}
\hline Outcome or subgroup title & $\begin{array}{l}\text { No. of } \\
\text { studies }\end{array}$ & $\begin{array}{l}\text { No. of } \\
\text { partici- } \\
\text { pants }\end{array}$ & Statistical method & Effect size \\
\hline 1.1.2 Itraconazole vs Clotrimazole & 3 & 436 & Odds Ratio (M-H, Fixed, 95\% Cl) & $1.41[0.86,2.33]$ \\
\hline 1.1.3 Fluconazole vs Miconazole & 1 & 93 & Odds Ratio (M-H, Fixed, 95\% Cl) & $1.23[0.45,3.42]$ \\
\hline 1.1.4 Fluconazole vs Econazole & 1 & 230 & Odds Ratio (M-H, Fixed, 95\% Cl) & $1.51[0.46,4.89]$ \\
\hline 1.1.5 Itraconazole vs Econazole & 1 & 75 & Odds Ratio (M-H, Fixed, 95\% Cl) & $1.70[0.64,4.55]$ \\
\hline $\begin{array}{l}\text { 1.1.6 Fluconazole vs Butocona- } \\
\text { zole }\end{array}$ & 1 & 136 & Odds Ratio (M-H, Fixed, 95\% Cl) & $0.66[0.33,1.30]$ \\
\hline $\begin{array}{l}\text { 1.1.7 Fluconazole vs Fenticona- } \\
\text { zole }\end{array}$ & 1 & 80 & Odds Ratio (M-H, Fixed, 95\% Cl) & $0.89[0.34,2.33]$ \\
\hline 1.2 Clinical cure (long term) & 9 & 1042 & Odds Ratio (M-H, Fixed, 95\% Cl) & $1.07[0.77,1.50]$ \\
\hline 1.2.1 Fluconazole vs Clotrimzole & 4 & 564 & Odds Ratio (M-H, Fixed, 95\% Cl) & $1.01[0.65,1.57]$ \\
\hline 1.2.2 Itraconazole vs Clotrimazole & 1 & 53 & Odds Ratio (M-H, Fixed, 95\% Cl) & $2.15[0.63,7.37]$ \\
\hline 1.2.3 Fluconazole vs Miconazole & 1 & 93 & Odds Ratio (M-H, Fixed, 95\% Cl) & $1.54[0.51,4.66]$ \\
\hline 1.2.4 Fluconazole vs Econazole & 1 & 177 & Odds Ratio (M-H, Fixed, 95\% Cl) & $1.05[0.40,2.72]$ \\
\hline 1.2.5 Itraconazole vs Econazole & 1 & 75 & Odds Ratio (M-H, Fixed, 95\% Cl) & $0.69[0.20,2.41]$ \\
\hline $\begin{array}{l}\text { 1.2.6 Fluconazole vs Fenticona- } \\
\text { zole }\end{array}$ & 1 & 80 & Odds Ratio (M-H, Fixed, 95\% Cl) & $0.65[0.10,4.11]$ \\
\hline 1.3 Mycological cure (short term) & 19 & 3057 & Odds Ratio (M-H, Fixed, 95\% Cl) & $1.24[1.03,1.50]$ \\
\hline 1.3.1 Fluconazole vs Clotrimazole & 12 & 1927 & Odds Ratio (M-H, Fixed, 95\% Cl) & $1.18[0.93,1.49]$ \\
\hline 1.3.2 Itraconazole vs Clotrimazole & 4 & 631 & Odds Ratio (M-H, Fixed, 95\% Cl) & $1.12[0.73,1.71]$ \\
\hline 1.3.3 Fluconazole vs Miconazole & 2 & 194 & Odds Ratio (M-H, Fixed, 95\% Cl) & $0.74[0.26,2.06]$ \\
\hline 1.3.4 Fluconazole vs Econazole & 1 & 230 & Odds Ratio (M-H, Fixed, 95\% Cl) & $1.93[0.97,3.83]$ \\
\hline 1.3.5 Itraconazole vs Econazole & 1 & 75 & Odds Ratio (M-H, Fixed, 95\% Cl) & $3.55[1.29,9.77]$ \\
\hline 1.4 Mycological cure (long term) & 13 & 1661 & Odds Ratio (M-H, Fixed, 95\% Cl) & $1.29[1.05,1.60]$ \\
\hline 1.4.1 Fluconazole vs Clotrimazole & 7 & 1015 & Odds Ratio (M-H, Fixed, 95\% Cl) & $1.31[1.00,1.71]$ \\
\hline 1.4.2 Itraconazole vs Clotrimazole & 2 & 200 & Odds Ratio (M-H, Fixed, 95\% Cl) & $1.09[0.60,1.98]$ \\
\hline 1.4.3 Fluconazole vs Miconazole & 2 & 194 & Odds Ratio (M-H, Fixed, 95\% Cl) & $0.72[0.37,1.40]$ \\
\hline 1.4.4 Fluconazole vs Econazole & 1 & 177 & Odds Ratio (M-H, Fixed, 95\% Cl) & $2.17[1.06,4.42]$ \\
\hline 1.4.5 Itraconazole vs Econazole & 1 & 75 & Odds Ratio (M-H, Fixed, 95\% Cl) & $2.26[0.89,5.74]$ \\
\hline
\end{tabular}




\begin{tabular}{|c|c|c|c|c|}
\hline Outcome or subgroup title & $\begin{array}{l}\text { No. of } \\
\text { studies }\end{array}$ & $\begin{array}{l}\text { No. of } \\
\text { partici- } \\
\text { pants }\end{array}$ & Statistical method & Effect size \\
\hline $\begin{array}{l}1.5 \text { Safety - number of with- } \\
\text { drawals due to adverse events }\end{array}$ & 23 & & Other data & No numeric data \\
\hline 1.6 Side effects & 16 & 3155 & Odds Ratio (M-H, Fixed, 95\% Cl) & $1.04[0.84,1.29]$ \\
\hline 1.6.1 Fluconazole vs Clotrimazole & 7 & 1753 & Odds Ratio (M-H, Fixed, 95\% Cl) & $1.30[0.97,1.74]$ \\
\hline 1.6.2 Itraconazole vs Clotrimazole & 2 & 320 & Odds Ratio (M-H, Fixed, 95\% Cl) & $1.13[0.54,2.37]$ \\
\hline $\begin{array}{l}\text { 1.6.3 Fluconazole vs Fenticona- } \\
\text { zole }\end{array}$ & 1 & 80 & Odds Ratio (M-H, Fixed, 95\% Cl) & $1.54[0.24,9.75]$ \\
\hline 1.6.4 Fluconazole vs Miconazole & 3 & 505 & Odds Ratio (M-H, Fixed, 95\% Cl) & $0.75[0.43,1.31]$ \\
\hline 1.6.5 Fluconazole vs Econazole & 1 & 235 & Odds Ratio (M-H, Fixed, 95\% Cl) & $0.35[0.17,0.74]$ \\
\hline $\begin{array}{l}\text { 1.6.6 Fluconazole vs Butocona- } \\
\text { zole }\end{array}$ & 1 & 181 & Odds Ratio (M-H, Fixed, 95\% Cl) & $1.92[0.85,4.33]$ \\
\hline 1.6.7 Itraconazole vs Econazole & 1 & 81 & Odds Ratio (M-H, Fixed, 95\% Cl) & $0.46[0.13,1.66]$ \\
\hline 1.7 Treatment preference & 12 & & Other data & No numeric data \\
\hline 1.8 Time to first relief & 10 & & Other data & No numeric data \\
\hline
\end{tabular}


Analysis 1.1. Comparison 1: Oral versus Intra-vaginal, Outcome 1: Clinical cure (short term)

\begin{tabular}{|c|c|c|c|c|c|c|c|}
\hline \multirow{2}{*}{ Study or Subgroup } & \multicolumn{2}{|c|}{ Oral } & \multicolumn{2}{|c|}{ Intra-vaginal } & \multirow[b]{2}{*}{ Weight } & \multirow{2}{*}{$\begin{array}{c}\text { Odds Ratio } \\
\text { M-H, Fixed, 95\% CI }\end{array}$} & \multirow{2}{*}{$\begin{array}{c}\text { Odds Ratio } \\
\text { M-H, Fixed, 95\% CI }\end{array}$} \\
\hline & Events & Total & Events & Total & & & \\
\hline \multicolumn{8}{|c|}{ 1.1.1 Fluconazole vs Clotrimazole } \\
\hline Coric 2006 & 33 & 38 & 37 & 46 & $3.2 \%$ & $1.61[0.49,5.28]$ & \\
\hline Goode 1992 & 3 & 3 & 6 & 9 & $0.3 \%$ & $3.77[0.15,95.82]$ & \\
\hline Sekhavat 2011 & 53 & 72 & 41 & 70 & $7.9 \%$ & $1.97[0.97,4.00]$ & 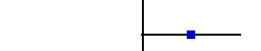 \\
\hline Sobel 1995 & 108 & 139 & 97 & 134 & $15.9 \%$ & $1.33[0.77,2.30]$ & \\
\hline Stein 1991 & 76 & 90 & 84 & 95 & $9.2 \%$ & $0.71[0.30,1.66]$ & $\longrightarrow=$ \\
\hline Woolley 1995 & 45 & 72 & 33 & 41 & $11.4 \%$ & $0.40[0.16,1.00]$ & \\
\hline Subtotal $(95 \%$ CI $)$ & & 414 & & 395 & $47.8 \%$ & $1.13[0.81,1.58]$ & \\
\hline Total events: & 318 & & 298 & & & & \\
\hline \multicolumn{8}{|c|}{ Heterogeneity: $\mathrm{Chi}^{2}=9.66, \mathrm{df}=5(\mathrm{P}=0.09) ; \mathrm{I}^{2}=48 \%$} \\
\hline \multicolumn{8}{|c|}{ Test for overall effect: $\mathrm{Z}=0.74(\mathrm{P}=0.46)$} \\
\hline \multicolumn{8}{|c|}{ 1.1.2 Itraconazole vs Clotrimazole } \\
\hline Sanam 2009 & 110 & 125 & 103 & 127 & $8.8 \%$ & $1.71[0.85,3.44]$ & \\
\hline Stein 1993 & 35 & 48 & 13 & 20 & $3.6 \%$ & $1.45[0.47,4.43]$ & \\
\hline Woolley 1995 & 60 & 75 & 33 & 41 & $6.1 \%$ & $0.97[0.37,2.53]$ & \\
\hline Subtotal $(95 \%$ CI $)$ & & 248 & & 188 & $18.6 \%$ & $1.41[0.86,2.33]$ & \\
\hline Total events: & 205 & & 149 & & & & \\
\hline \multicolumn{8}{|c|}{ Heterogeneity: $\mathrm{Chi}^{2}=0.88, \mathrm{df}=2(\mathrm{P}=0.64) ; \mathrm{I}^{2}=0 \%$} \\
\hline \multicolumn{8}{|c|}{ Test for overall effect: $\mathrm{Z}=1.36(\mathrm{P}=0.17)$} \\
\hline \multicolumn{8}{|c|}{ 1.1.3 Fluconazole vs Miconazole } \\
\hline Van Heusden 1990 & 35 & 43 & 39 & 50 & $4.8 \%$ & $1.23[0.45,3.42]$ & \\
\hline Subtotal $(95 \%$ CI $)$ & & 43 & & $\mathbf{5 0}$ & $4.8 \%$ & $1.23[0.45,3.42]$ & \\
\hline Total events: & 35 & & 39 & & & & \\
\hline \multicolumn{8}{|c|}{ Heterogeneity: Not applicable } \\
\hline \multicolumn{8}{|c|}{ Test for overall effect: $\mathrm{Z}=0.40(\mathrm{P}=0.69)$} \\
\hline \multicolumn{8}{|c|}{ 1.1.4 Fluconazole vs Econazole } \\
\hline Osser 1991 & 113 & 118 & 105 & 112 & $3.3 \%$ & $1.51[0.46,4.89]$ & \\
\hline Subtotal $(95 \%$ CI) & & 118 & & 112 & $3.3 \%$ & $1.51[0.46,4.89]$ & \\
\hline Total events: & 113 & & 105 & & & & \\
\hline \multicolumn{8}{|c|}{ Heterogeneity: Not applicable } \\
\hline \multicolumn{8}{|c|}{ Test for overall effect: $\mathrm{Z}=0.68(\mathrm{P}=0.50)$} \\
\hline \multicolumn{8}{|c|}{ 1.1.5 Itraconazole vs Econazole } \\
\hline Timonen 1992b & 28 & 38 & 23 & 37 & $4.4 \%$ & $1.70[0.64,4.55]$ & \\
\hline Subtotal $(95 \%$ CI) & & 38 & & 37 & $4.4 \%$ & $1.70[0.64,4.55]$ & \\
\hline Total events: & 28 & & 23 & & & & \\
\hline \multicolumn{8}{|c|}{ Heterogeneity: Not applicable } \\
\hline \multicolumn{8}{|c|}{ Test for overall effect: $\mathrm{Z}=1.07(\mathrm{P}=0.29)$} \\
\hline \multicolumn{8}{|c|}{ 1.1.6 Fluconazole vs Butoconazole } \\
\hline Seidman 2005 & 33 & 69 & 39 & 67 & $14.9 \%$ & $0.66[0.33,1.30]$ & \\
\hline Subtotal $(95 \%$ CI) & & 69 & & 67 & $14.9 \%$ & $0.66[0.33,1.30]$ & \\
\hline Total events: & 33 & & 39 & & & & \\
\hline Heterogeneity: Not ap & cable & & & & & & \\
\hline Test for overall effect & $=1.21(\mathrm{P}=$ & $0.23)$ & & & & & \\
\hline 1.1.7 Fluconazole vs & nticonazole & & & & & & \\
\hline Murina 2012 & 28 & 40 & 29 & 40 & $6.3 \%$ & $0.89[0.34,2.33]$ & \\
\hline
\end{tabular}


Analysis 1.1. (Continued)

1.1. I F ruconazoie vs remiconazoie

$\begin{array}{lcccccc}\text { Murina } 2012 & 28 & 40 & 29 & 40 & 6.3 \% & 0.89[0.34,2.33] \\ \text { Subtotal }(\mathbf{9 5 \%} \text { CI) } & & \mathbf{4 0} & & \mathbf{4 0} & \mathbf{6 . 3 \%} & \mathbf{0 . 8 9}[\mathbf{0 . 3 4}, \mathbf{2 . 3 3}] \\ \text { Total events: } & 28 & & 29 & & & \end{array}$

Heterogeneity: Not applicable

Test for overall effect: $\mathrm{Z}=0.25(\mathrm{P}=0.80)$

Total $(95 \%$ CI)

Total events:

970

Heterogeneity: $\mathrm{Chi}^{2}=14.90, \mathrm{df}=13(\mathrm{P}=0.31) ; \mathrm{I}^{2}=13 \%$

Test for overall effect: $\mathrm{Z}=1.14(\mathrm{P}=0.26)$

Test for subgroup differences: $\mathrm{Ch}^{2}=4.39, \mathrm{df}=6(\mathrm{P}=0.62), \mathrm{I}^{2}=0 \%$
$889 \quad 100.0 \% \quad 1.14[0.91,1.43]$

682

\begin{tabular}{lll}
\hline & 1 & \\
0.1 & 0.2 & 0.5
\end{tabular}

Favours intra-vaginal

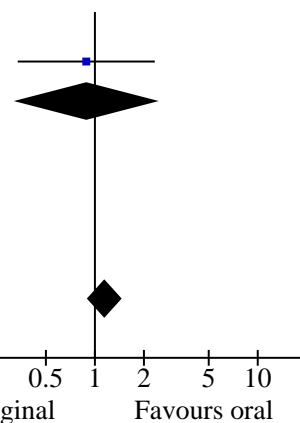


Analysis 1.2. Comparison 1: Oral versus Intra-vaginal, Outcome 2: Clinical cure (long term)

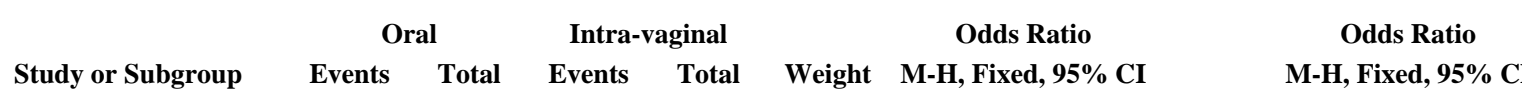

1.2.1 Fluconazole vs Clotrimzole

Goode 1992

$3 \quad 3$

M-H, Fixed, 95\% CI

Sobel 1995

Stein 1991

Škerk V 2006

Subtotal (95\% CI)

106

68

68

65

131

4

4

$\begin{array}{rr}7 & 0.6 \% \\ 125 & 30.8 \% \\ 86 & 22.7 \% \\ 55 & 6.8 \% \\ \mathbf{2 7 3} & \mathbf{6 0 . 9 \%}\end{array}$

$5.44[0.21,144.10]$

$0.91[0.48,1.71]$

$0.80[0.37,1.71]$

$1.84[0.60,5.67]$

$1.01[0.65,1.57]$

Total events:

242

291 225

Heterogeneity: $\mathrm{Chi}^{2}=2.60, \mathrm{df}=3(\mathrm{P}=0.46) ; \mathrm{I}^{2}=0 \%$

Test for overall effect: $\mathrm{Z}=0.06(\mathrm{P}=0.95)$

1.2.2 Itraconazole vs Clotrimazole

$\begin{array}{lllllll}\text { Stein } 1993 & 27 & 35 & 11 & 18 & 5.1 \% & 2.15[0.63,7.37] \\ \text { Subtotal }(\mathbf{9 5 \%} \text { CI) } & & \mathbf{3 5} & & \mathbf{1 8} & \mathbf{5 . 1 \%} & \mathbf{2 . 1 5}[\mathbf{0 . 6 3}, \mathbf{7 . 3 7}] \\ \text { Total events: } & 27 & & 11 & & & \end{array}$

Heterogeneity: Not applicable

Test for overall effect: $\mathrm{Z}=1.22(\mathrm{P}=0.22)$

1.2.3 Fluconazole vs Miconazole

$\begin{array}{lcccccc}\text { Van Heusden } 1990 & 37 & 43 & 40 & 50 & 7.9 \% & 1.54[0.51,4.66] \\ \text { Subtotal }(\mathbf{9 5 \%} \text { CI) } & & \mathbf{4 3} & & \mathbf{5 0} & \mathbf{7 . 9 \%} & \mathbf{1 . 5 4}[\mathbf{0 . 5 1 , \mathbf { 4 . 6 6 }}] \\ \text { Total events: } & 37 & & 40 & & & \end{array}$

Heterogeneity: Not applicable

Test for overall effect: $Z=0.77(P=0.44)$

\subsubsection{Fluconazole vs Econazole}

$\begin{array}{lcccccc}\text { Osser } 1991 & 85 & 95 & 73 & 82 & 12.6 \% & 1.05[0.40,2.72] \\ \text { Subtotal }(\mathbf{9 5 \%} \text { CI) } & & \mathbf{9 5} & & \mathbf{8 2} & \mathbf{1 2 . 6 \%} & \mathbf{1 . 0 5}[\mathbf{0 . 4 0 , 2 . 7 2}] \\ \text { Total events: } & 85 & & 73 & & & \end{array}$

Heterogeneity: Not applicable

Test for overall effect: $Z=0.10(P=0.92)$

\subsubsection{Itraconazole vs Econazole}

$\begin{array}{lllllll}\text { Timonen } 1992 \mathrm{~b} & 31 & 38 & 32 & 37 & 9.1 \% & 0.69[0.20,2.41] \\ \text { Subtotal }(\mathbf{9 5 \%} \mathbf{C I}) & & \mathbf{3 8} & & \mathbf{3 7} & \mathbf{9 . 1 \%} & \mathbf{0 . 6 9}[\mathbf{0 . 2 0}, \mathbf{2 . 4 1}] \\ \text { Total events: } & 31 & & 32 & & & \end{array}$

Heterogeneity: Not applicable

Test for overall effect: $\mathrm{Z}=0.58(\mathrm{P}=0.56)$

\subsubsection{Fluconazole vs Fenticonazole}

$\begin{array}{llllll}\text { Murina } 2012 & 37 & 40 & 38 & 40 & 4.4 \% \\ \text { Subtotal }(\mathbf{9 5 \%} \text { CI) } & & \mathbf{4 0} & & \mathbf{4 0} & \mathbf{4 . 4 \%} \\ \text { Total events: } & 37 & & 38 & & \end{array}$

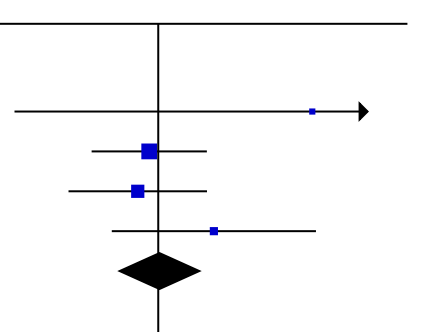

Heterogeneity: Not applicable

Test for overall effect: $\mathrm{Z}=0.46(\mathrm{P}=0.65)$

Total (95\% CI)

Total events:

542

$459 \quad 419$

Heterogeneity: $\mathrm{Chi}^{2}=5.08, \mathrm{df}=8(\mathrm{P}=0.75) ; \mathrm{I}^{2}=0 \%$

Test for overall effect: $\mathrm{Z}=0.40(\mathrm{P}=0.69)$

Test for subgroup differences: $\mathrm{Chi}^{2}=2.45, \mathrm{df}=5(\mathrm{P}=0.78), \mathrm{I}^{2}=0 \%$
$0.65[0.10,4.11]$

$0.65[0.10,4.11]$

$500 \quad 100.0 \%$

$1.07[0.77,1.50]$

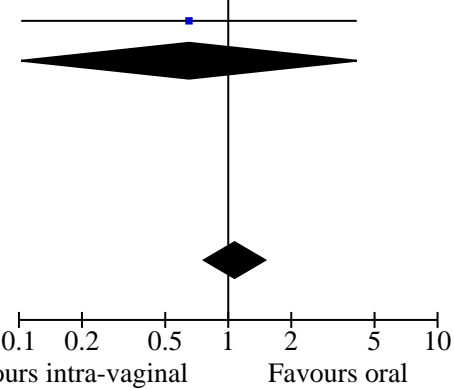


Analysis 1.3. Comparison 1: Oral versus Intra-vaginal, Outcome 3: Mycological cure (short term)

\begin{tabular}{lrrrrrr} 
& \multicolumn{2}{c}{ Oral } & \multicolumn{2}{c}{ Intra-vaginal } & Odds Ratio \\
Study or Subgroup & Events & Total & Events & Total & Weight & M-H, Fixed, 95\% CI \\
\hline 1.3.1 Fluconazole vs Clotrimazole & & & & & & \\
Adetoro 1990 & 20 & 23 & 15 & 20 & $1.1 \%$ & $2.22[0.46,10.79]$ \\
Andersen 1989 & 143 & 169 & 131 & 161 & $10.6 \%$ & $1.26[0.71,2.24]$ \\
Boag 1991 & 10 & 11 & 6 & 9 & $0.3 \%$ & $5.00[0.42,59.66]$ \\
Coric 2006 & 33 & 38 & 37 & 46 & $2.3 \%$ & $1.61[0.49,5.28]$ \\
Goode 1992 & 2 & 3 & 8 & 9 & $0.7 \%$ & $0.25[0.01,5.98]$ \\
Mendling 2004 & 117 & 154 & 245 & 318 & $19.7 \%$ & $0.94[0.60,1.48]$ \\
Mikamo 1995 & 82 & 100 & 36 & 50 & $4.4 \%$ & $1.77[0.80,3.95]$ \\
O-Prasertsawat 1995 & 42 & 53 & 40 & 50 & $4.4 \%$ & $0.95[0.37,2.49]$ \\
Sekhavat 2011 & 60 & 72 & 49 & 70 & $4.3 \%$ & $2.14[0.96,4.79]$ \\
Sobel 1995 & 113 & 139 & 102 & 134 & $10.0 \%$ & $1.36[0.76,2.44]$ \\
Stein 1991 & 80 & 90 & 88 & 95 & $4.9 \%$ & $0.64[0.23,1.75]$ \\
Woolley 1995 & 60 & 72 & 39 & 41 & $4.3 \%$ & $0.26[0.05,1.21]$ \\
Subtotal (95\% CI) & & $\mathbf{9 2 4}$ & & $\mathbf{1 0 0 3}$ & $\mathbf{6 6 . 9 \%}$ & $\mathbf{1 . 1 8}[\mathbf{0 . 9 3}, \mathbf{1 . 4 9}]$ \\
The & & & & & &
\end{tabular}

Total events: $\quad 762 \quad 796$

Heterogeneity: $\mathrm{Chi}^{2}=12.78, \mathrm{df}=11(\mathrm{P}=0.31) ; \mathrm{I}^{2}=14 \%$

Test for overall effect: $\mathrm{Z}=1.36(\mathrm{P}=0.17)$

1.3.2 Itraconazole vs Clotrimazole

\section{0}

Stein 1993

35

Tobin 1992

Woolley 1995

Subtotal (95\% CI)

Test for overall effect: $\mathrm{Z}=0.52(\mathrm{P}=0.61)$

\subsubsection{Fluconazole vs Miconazole}

Timonen 1992

Van Heusden 1990

Heterogeneity: $\mathrm{Chi}^{2}=0.61, \mathrm{df}=1(\mathrm{P}=0.43) ; \mathrm{I}^{2}=0 \%$

Test for overall effect: $Z=0.59(P=0.56)$

1.3.4 Fluconazole vs Econazole

$\begin{array}{lcccccc}\text { Osser } 1991 & 102 & 118 & 86 & 112 & 6.1 \% & 1.93[0.97,3.83] \\ \text { Subtotal (95\% CI) } & & \mathbf{1 1 8} & & \mathbf{1 1 2} & \mathbf{6 . 1 \%} & \mathbf{1 . 9 3}[\mathbf{0 . 9 7}, \mathbf{3 . 8 3}] \\ \text { Total events: } & 102 & & 86 & & & \end{array}$

Heterogeneity: Not applicable

Test for overall effect: $\mathrm{Z}=1.88(\mathrm{P}=0.06)$

1.3.5 Itraconazole vs Econazole

$\begin{array}{lllllll}\text { Timonen } 1992 \mathrm{~b} & 30 & 38 & 19 & 37 & 2.1 \% & 3.55[1.29,9.77] \\ \text { Subtotal }(\mathbf{9 5 \%} \text { CI) } & & \mathbf{3 8} & & \mathbf{3 7} & \mathbf{2 . 1 \%} & \mathbf{3 . 5 5}[\mathbf{1 . 2 9}, \mathbf{9 . 7 7}] \\ \text { Total events: } & 30 & & 19 & & & \end{array}$

Heterogeneity: Not applicable

Test for overall effect: $Z=2.46(P=0.01)$

Total (95\% CI)

Total events:
1524 1271
$1533 \quad 100.0 \%$

$1.24[1.03,1.50]$
Odds Ratio M-H, Fixed, 95\% CI 
Analysis 1.3. (Continued)

Total (95\% CI)

Total events:

1524

Heterogeneity: $\mathrm{Chi}^{2}=25.22, \mathrm{df}=19(\mathrm{P}=0.15) ; \mathrm{I}^{2}=25 \%$

Test for overall effect: $\mathrm{Z}=2.24(\mathrm{P}=0.02)$

Test for subgroup differences: $\mathrm{Chi}^{2}=7.16, \mathrm{df}=4(\mathrm{P}=0.13), \mathrm{I}^{2}=44.1 \%$
$1533 \quad 100.0 \%$

$1.24[1.03,1.50]$

1221

(1)

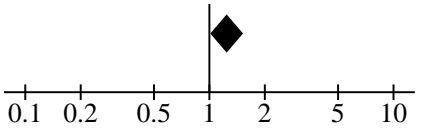

Favours intra-vaginal
Favours oral 
Analysis 1.4. Comparison 1: Oral versus Intra-vaginal, Outcome 4: Mycological cure (long term)

Oral Events Total
Intra-vaginal

Events Total

Odds Ratio

Weight M-H, Fixed, 95\% CI
Odds Ratio

M-H, Fixed, $95 \%$ CI

\subsubsection{Fluconazole vs Clotrimazole}

\section{Adetoro 1990}

Andersen 1989

Goode 1992

Mikamo 1995

O-Prasertsawat 1995

Sobel 1995

Stein 1991

\section{Subtotal (95\% CI)}

Total events:

20
115

23
160

23
160

3

75

32

90

90
57

57

3

100

53

$$
\begin{array}{r}
131 \\
74
\end{array}
$$$$
544
$$

Heterogeneity: $\mathrm{Chi}^{2}=11.06, \mathrm{df}=6(\mathrm{P}=0.09) ; \mathrm{I}^{2}=46 \%$

Test for overall effect: $\mathrm{Z}=1.96(\mathrm{P}=0.05)$

\subsubsection{Itraconazole vs Clotrimazole}

Stein 1993

Tobin 1992

Subtotal (95\% CI)

36

$$
35
$$

12

12

20

$20 \quad 1.1 \%$

$145 \quad 17.8 \%$

4

30

33

80

64

64 313

Total events: 67

Heterogeneity: $\mathrm{Chi}^{2}=0.21, \mathrm{df}=1(\mathrm{P}=0.64) ; \mathrm{I}^{2}=0 \%$

Test for overall effect: $\mathrm{Z}=0.27(\mathrm{P}=0.79)$

\subsubsection{Fluconazole vs Miconazole}

$\begin{array}{lllllll}\text { Timonen 1992a } & 39 & 54 & 36 & 47 & 7.2 \% & 0.79[0.32,1.95] \\ \text { Van Heusden 1990 } & 32 & 43 & 41 & 50 & 6.5 \% & 0.64[0.24,1.73] \\ \text { Subtotal (95\% CI) } & & \mathbf{9 7} & & \mathbf{9 7} & \mathbf{1 3 . 7 \%} & \mathbf{0 . 7 2}[\mathbf{0 . 3 7}, \mathbf{1 . 4 0}]\end{array}$

Total events: $\quad 71 \quad 77$

Heterogeneity: $\mathrm{Chi}^{2}=0.10, \mathrm{df}=1(\mathrm{P}=0.75) ; \mathrm{I}^{2}=0 \%$

Test for overall effect: $\mathrm{Z}=0.96(\mathrm{P}=0.34)$

\subsubsection{Fluconazole vs Econazole}

Osser 1991 79

Subtotal $(95 \%$ CI)

95
95

Total events: 79

95

Heterogeneity: Not applicable

Test for overall effect: $\mathrm{Z}=2.12(\mathrm{P}=0.03)$

1.4.5 Itraconazole vs Econazole

$\begin{array}{lcccccc}\text { Timonen } 1992 \mathrm{~b} & 25 & 38 & 17 & 37 & 3.9 \% & 2.26[0.89,5.74] \\ \begin{array}{l}\text { Subtotal }(\mathbf{9 5 \%} \mathbf{C I}) \\ \text { Total events: }\end{array} & & \mathbf{3 8} & & \mathbf{3 7} & \mathbf{3 . 9 \%} & \mathbf{2 . 2 6}[\mathbf{0 . 8 9}, \mathbf{5 . 7 4}] \\ & 25 & & 17 & & & \end{array}$

Heterogeneity: Not applicable

Test for overall effect: $\mathrm{Z}=1.72(\mathrm{P}=0.09)$

Total $(95 \%$ CI $)$

Total events: 634

880

Heterogeneity: $\mathrm{Chi}^{2}=18.04, \mathrm{df}=12(\mathrm{P}=0.11) ; \mathrm{I}^{2}=33 \%$

Test for overall effect: $\mathrm{Z}=2.38(\mathrm{P}=0.02)$

Test for subgroup differences: $\mathrm{Chi}^{2}=6.67, \mathrm{df}=4(\mathrm{P}=0.15), \mathrm{I}^{2}=40.0 \%$
$4.44[0.98,20.07]$

$1.56[0.97,2.53]$

$2.00[0.97,4.13]$

$0.78[0.35,1.75]$

$1.23[0.73,2.08]$

$0.52[0.22,1.24]$

$1.31[1.00,1.71]$

$1.55[0.31,7.82]$

$1.03[0.54,1.96]$

$1.09[0.60,1.98]$

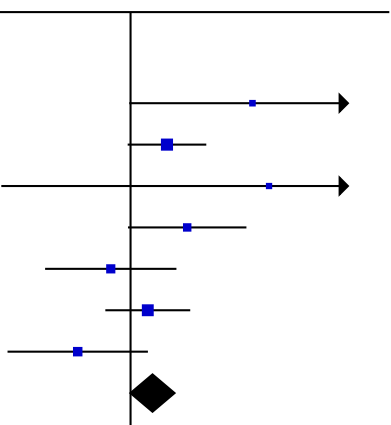




\section{Analysis 1.5. Comparison 1: Oral versus Intra-vaginal, Outcome} 5: Safety - number of withdrawals due to adverse events

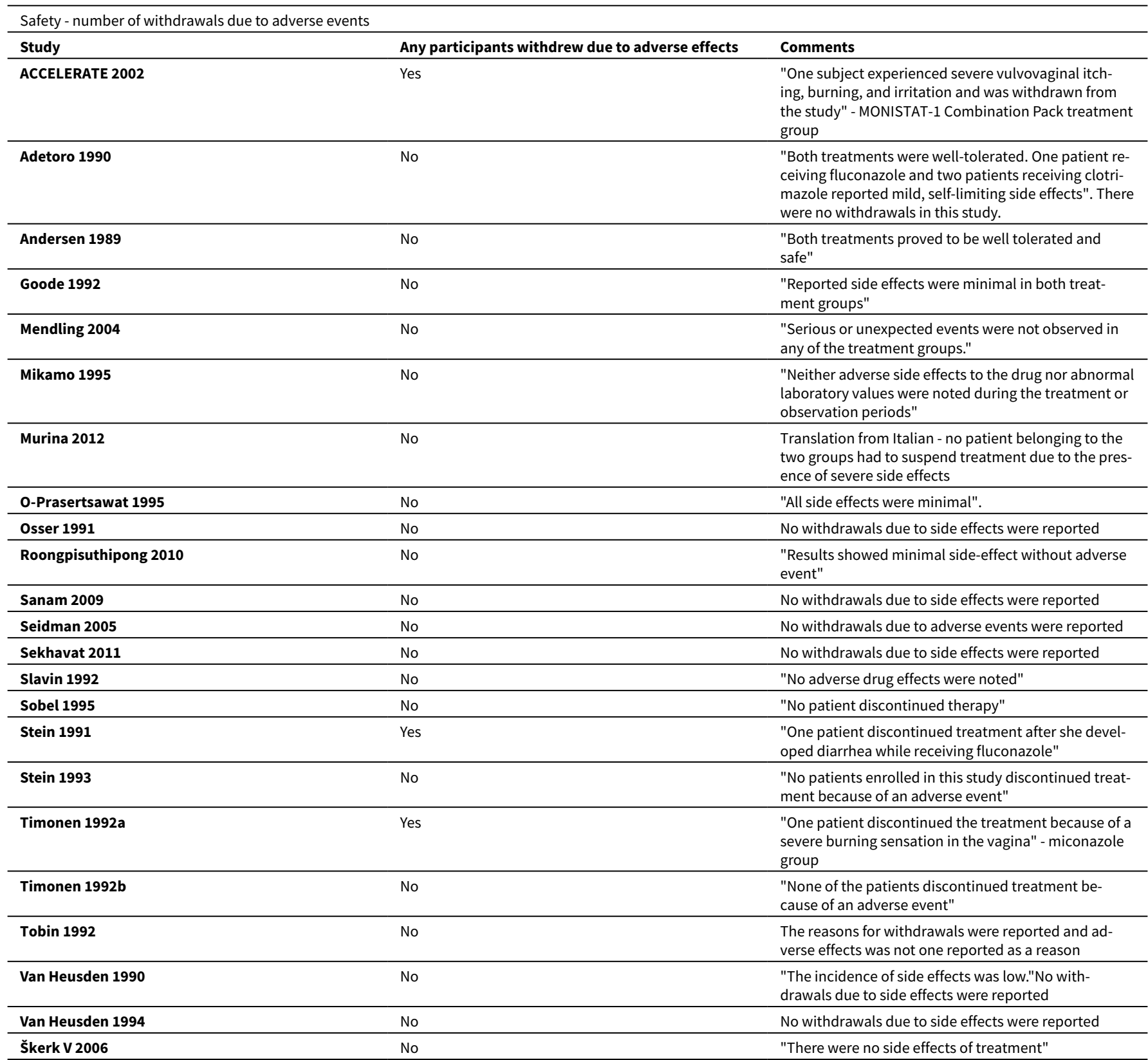


Analysis 1.6. Comparison 1: Oral versus Intra-vaginal, Outcome 6: Side effects

\begin{tabular}{|c|c|c|c|c|c|c|}
\hline \multirow[b]{2}{*}{ Study or Subgroup } & \multicolumn{2}{|c|}{ Oral } & \multicolumn{2}{|c|}{ Intra-vaginal } & \multirow[b]{2}{*}{ Weight } & \multirow{2}{*}{$\begin{array}{c}\text { Odds Ratio } \\
\text { M-H, Fixed, 95\% CI }\end{array}$} \\
\hline & Events & Total & Events & Total & & \\
\hline \multicolumn{7}{|c|}{ 1.6.1 Fluconazole vs Clotrimazole } \\
\hline Adetoro 1990 & 1 & 23 & 2 & 20 & $1.3 \%$ & $0.41[0.03,4.88]$ \\
\hline Andersen 1989 & 8 & 188 & 9 & 181 & $5.4 \%$ & $0.85[0.32,2.25]$ \\
\hline Mendling 2004 & 29 & 227 & 26 & 226 & $14.0 \%$ & $1.13[0.64,1.98]$ \\
\hline O-Prasertsawat 1995 & 4 & 53 & 11 & 50 & $6.5 \%$ & $0.29[0.09,0.98]$ \\
\hline Sekhavat 2011 & 5 & 72 & 3 & 70 & $1.7 \%$ & $1.67[0.38,7.26]$ \\
\hline Sobel 1995 & 59 & 217 & 37 & 212 & $16.8 \%$ & $1.77[1.11,2.81]$ \\
\hline Stein 1991 & 12 & 102 & 5 & 112 & $2.6 \%$ & $2.85[0.97,8.40]$ \\
\hline Subtotal (95\% CI) & & 882 & & 871 & $48.3 \%$ & $1.30[0.97,1.74]$ \\
\hline Total events: & 118 & & 93 & & & \\
\hline
\end{tabular}

Heterogeneity: $\mathrm{Chi}^{2}=11.47, \mathrm{df}=6(\mathrm{P}=0.07) ; \mathrm{I}^{2}=48 \%$

Test for overall effect: $\mathrm{Z}=1.75(\mathrm{P}=0.08)$

1.6.2 Itraconazole vs Clotrimazole

$\begin{array}{lrrrrrr}\text { Sanam } 2009 & 6 & 125 & 13 & 127 & 7.6 \% & 0.44[0.16,1.20] \\ \text { Stein } 1993 & 17 & 48 & 1 & 20 & 0.6 \% & 10.42[1.28,84.75] \\ \text { Subtotal (95\% CI) } & & \mathbf{1 7 3} & & \mathbf{1 4 7} & \mathbf{8 . 1 \%} & \mathbf{1 . 1 3}[\mathbf{0 . 5 4}, \mathbf{2 . 3 7}] \\ \text { Total events: } & 23 & & 14 & & & \end{array}$

Heterogeneity: $\mathrm{Chi}^{2}=7.70, \mathrm{df}=1(\mathrm{P}=0.006) ; \mathrm{I}^{2}=87 \%$

Test for overall effect: $Z=0.33(P=0.74)$

1.6.3 Fluconazole vs Fenticonazole

$\begin{array}{lllllll}\text { Murina } 2012 & 3 & 40 & 2 & 40 & 1.1 \% & 1.54[0.24,9.75] \\ \text { Subtotal }(\mathbf{9 5 \%} \text { CI) } & & \mathbf{4 0} & & \mathbf{4 0} & \mathbf{1 . 1 \%} & \mathbf{1 . 5 4}[\mathbf{0 . 2 4}, \mathbf{9 . 7 5}] \\ \text { Total events: } & 3 & & 2 & & & \end{array}$

Heterogeneity: Not applicable

Test for overall effect: $\mathrm{Z}=0.46(\mathrm{P}=0.65)$

1.6.4 Fluconazole vs Miconazole

$\begin{array}{lrrrrr}\text { ACCELERATE 2002 } & 17 & 149 & 17 & 156 & 9.1 \% \\ \text { Timonen 1992a } & 5 & 54 & 9 & 47 & 5.4 \% \\ \text { Van Heusden 1990 } & 2 & 49 & 5 & 50 & 2.9 \% \\ \text { Subtotal (95\% CI) } & & \mathbf{2 5 2} & & \mathbf{2 5 3} & \mathbf{1 7 . 4 \%} \\ \text { Total events: } & 24 & & 31 & & \end{array}$

$1.05[0.52,2.15]$

$0.43[0.13,1.39]$

$0.38[0.07,2.08]$

Total events:
Heterogeneity: $\mathrm{Chi}^{2}=2.34, \mathrm{df}=2(\mathrm{P}=0.31) ; \mathrm{I}^{2}=14 \%$

Test for overall effect: $Z=1.01(P=0.31)$

$0.75[0.43,1.31]$

1.6.5 Fluconazole vs Econazole

$\begin{array}{lcccccc}\text { Osser } 1991 & 12 & 121 & 27 & 114 & 15.4 \% & 0.35[0.17,0.74] \\ \text { Subtotal (95\% CI) } & & \mathbf{1 2 1} & & \mathbf{1 1 4} & \mathbf{1 5 . 4 \%} & \mathbf{0 . 3 5}[\mathbf{0 . 1 7}, \mathbf{0 . 7 4}] \\ \text { Total events: } & 12 & & 27 & & & \end{array}$

Heterogeneity: Not applicable

Test for overall effect: $\mathrm{Z}=2.76(\mathrm{P}=0.006)$

1.6.6 Fluconazole vs Butoconazole

$\begin{array}{lllllll}\text { Seidman } 2005 & 18 & 88 & 11 & 93 & 5.2 \% & 1.92[0.85,4.33] \\ \text { Subtotal }(\mathbf{9 5 \%} \text { CI) } & & \mathbf{8 8} & & \mathbf{9 3} & \mathbf{5 . 2 \%} & \mathbf{1 . 9 2}[\mathbf{0 . 8 5}, \mathbf{4 . 3 3}]\end{array}$

Total events: $\quad 18$

11

Heterogeneity: Not applicable

Test for overall effect: $\mathrm{Z}=1.56(\mathrm{P}=0.12)$

1.6.7 Itraconazole vs Econazole

$\begin{array}{lllllll}\text { Timonen } 1992 \mathrm{~b} & 4 & 40 & 8 & 41 & 4.4 \% & 0.46[0.13,1.66] \\ \text { Subtotal }(95 \% \text { CI) } & & \mathbf{4 0} & & \mathbf{4 1} & \mathbf{4 . 4 \%} & \mathbf{0 . 4 6}[0.13 .1 .66]\end{array}$

Odds Ratio

M-H, Fixed, $95 \%$ CI 
Analysis 1.6. (Continued)

$\begin{array}{lllllll}\text { Timonen } 1992 \mathrm{~b} & 4 & 40 & 8 & 41 & 4.4 \% & 0.46[0.13,1.66] \\ \text { Subtotal }(\mathbf{9 5 \%} \text { CI) } & & \mathbf{4 0} & & \mathbf{4 1} & \mathbf{4 . 4 \%} & \mathbf{0 . 4 6}[\mathbf{0 . 1 3}, \mathbf{1 . 6 6}] \\ \text { Total events: } & 4 & & 8 & & & \end{array}$

Heterogeneity: Not applicable

Test for overall effect: $Z=1.19(P=0.24)$

Total $(95 \%$ CI $)$

$1.04[0.84,1.29]$

Total events:

202

186

Heterogeneity: $\mathrm{Chi}^{2}=36.82, \mathrm{df}=15(\mathrm{P}=0.001) ; \mathrm{I}^{2}=59 \%$

Test for overall effect: $\mathrm{Z}=0.38(\mathrm{P}=0.71)$

Test for subgroup differences: $\mathrm{Chi}^{2}=15.66, \mathrm{df}=6(\mathrm{P}=0.02), \mathrm{I}^{2}=61.7 \%$

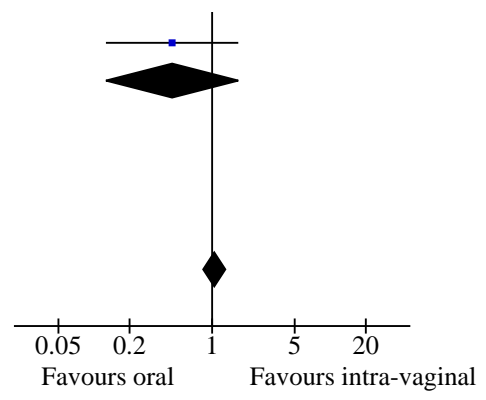

\section{Analysis 1.7. Comparison 1: Oral versus Intra-vaginal, Outcome 7: Treatment preference}

\begin{tabular}{|c|c|c|c|c|c|}
\hline \multicolumn{6}{|c|}{ Treatment preference } \\
\hline Study & $\begin{array}{l}\text { Prefer oral } \\
\text { n (\%) }\end{array}$ & $\begin{array}{l}\text { Prefer vaginal } \\
\mathrm{n}(\%)\end{array}$ & Notes & $\mathrm{n}$ & Soft vote count \\
\hline Adetoro 1990 & & & $\begin{array}{l}\text { No numbers provided. } \\
\text { Comment in paper: "It } \\
\text { was also noted that vir- } \\
\text { tually all treated patients } \\
\text { preferred oral treatment } \\
\text { to the more convention- } \\
\text { al intravaginal therapy." }\end{array}$ & 43 & Oral \\
\hline Andersen 1989 & $25(65.8)$ & $0(0)$ & $\begin{array}{l}\text { Data were from only one } \\
\text { treatment group (flu- } \\
\text { conazole treated group) } \\
\text { at only one centre. }\end{array}$ & 45 & Oral \\
\hline Coric 2006 & $93(78.2)$ & $26(21.8)$ & & 119 & Oral \\
\hline Osser 1991 & $\begin{array}{l}\text { Fluconazole group } \\
(68.3) \\
\text { Econazole group } \\
(38.8 \%)\end{array}$ & $\begin{array}{l}\text { Fluconazole group } \\
(13.8) \\
\text { Econazole group } \\
(25.6 \%)\end{array}$ & $\begin{array}{l}17.9 \% \text { of the women ad- } \\
\text { ministered fluconazole } \\
\text { expressed no opinion. } \\
35.6 \% \text { of the women ad- } \\
\text { ministered econazole ex- } \\
\text { pressed no opinion. }\end{array}$ & 235 & Oral \\
\hline Sekhavat 2011 & & & $\begin{array}{l}\text { Comment in paper: } \\
\text { "More than } 97 \% \text { patients } \\
\text { enrolled in the study } \\
\text { would prefer oral } \\
\text { fluconazole treatment } \\
\text { compared to topical } \\
\text { clotrimazole } 68.6 \% \text { ( } \mathrm{p}= \\
0.001) . " \\
\end{array}$ & 142 & Oral \\
\hline Slavin 1992 & & & $\begin{array}{l}\text { Comment in paper: } \\
\text { "Seventy-three percent } \\
\text { of the study patients pre- } \\
\text { ferred oral therapy } \\
\text { compared to intravagi- } \\
\text { nal for the treatment of } \\
\text { candida vaginitis." }\end{array}$ & 22 & Oral \\
\hline Stein 1993 & & & $\begin{array}{l}\text { No numbers provided. } \\
\text { Comment in paper: "Itra- } \\
\text { conazole therapy was } \\
\text { highly favored over ther- } \\
\text { apy with clotrimazole in } \\
\text { our survey of patients". }\end{array}$ & 95 & Oral \\
\hline Timonen 1992a & $\begin{array}{l}\text { Fluconazole group } 50 \\
\text { (92.6) } \\
\text { Miconazole group } 33 \\
(70.2) \\
(80.2)\end{array}$ & $\begin{array}{l}\text { Fluconazole group } 1(1.9) \\
\text { Miconazole group } 3(6.4) \\
\text { (4.9) }\end{array}$ & $\begin{array}{l}\text { No preference: } \\
\text { Fluconazole group } 3 \text { (5.6) } \\
\text { Miconazole group 11 } \\
\text { (23.4) } \\
\text { I think the numbers are } \\
65 \text { and 6, but not given in } \\
\text { paper. } \\
15 \% \text { did not state a pref- } \\
\text { erence }\end{array}$ & 101 & Oral \\
\hline
\end{tabular}

Oral versus intra-vaginal imidazole and triazole anti-fungal treatment of uncomplicated vulvovaginal candidiasis (thrush) (Review) 


\begin{tabular}{|c|c|c|c|c|c|}
\hline Timonen 1992b & $(80.2)$ & (4.9) & $\begin{array}{l}15 \% \text { did not state a pref- } \\
\text { erence }\end{array}$ & 81 & Oral \\
\hline Tobin 1992 & & & $\begin{array}{l}\text { Provides data on } \\
\text { whether participants } \\
\text { preferred the study } \\
\text { treatment } \\
\text { (itraconazole or clotri- } \\
\text { mazole) to previous } \\
\text { treatments received, } \\
\text { but it is not recorded } \\
\text { whether the previous } \\
\text { treatments were oral or } \\
\text { vaginal. }\end{array}$ & 180 & $\mathrm{~N} / \mathrm{A}$ \\
\hline Van Heusden 1990 & $43(46.2)$ & $4(4.3)$ & $\begin{array}{l}46(49.5 \%) \text { had no prefer- } \\
\text { ence }\end{array}$ & 93 & No preference \\
\hline Van Heusden 1994 & $(52)$ & $(17)$ & $\begin{array}{l}\text { In addition, } 26 \% \text { had no } \\
\text { preference, and } 5 \% \text { said } \\
\text { 'other' preference. }\end{array}$ & 471 & Oral \\
\hline
\end{tabular}

Analysis 1.8. Comparison 1: Oral versus Intra-vaginal, Outcome 8: Time to first relief

\begin{tabular}{|c|c|c|c|}
\hline \multicolumn{4}{|l|}{ Time to first relief } \\
\hline Study & Data reported & Results & Notes \\
\hline ACCELERATE 2002 & $\begin{array}{l}\text { Median time to initial relief } \\
\text { Proportion of patients at timepoints }\end{array}$ & $\begin{array}{l}\text { Miconazole (intravaginal) treatment } \\
\text { group }=1.0 \text { hour for individual symp- } \\
\text { toms and } 4.0 \text { hours for all symptoms } \\
\text { combined. Fluconazole (oral) treatment } \\
\text { group }=4.0 \text { hours for individual symp- } \\
\text { toms and } 16.0 \text { hours for all symptoms } \\
\text { combined. } \\
\text { Miconazole treatment group = Initial } \\
\text { relief was reported by } 16.0 \% \text { of sub- } \\
\text { jects at } 20 \text { minutes following dosing, by } \\
30.7 \% \text { at } 40 \text { minutes, and by } 96.0 \% \text { of } \\
\text { subjects at } 72 \text { hours. Fluconazole treat- } \\
\text { ment group }=\text { Initial relief was reported } \\
\text { by } 5.0 \% \text { of subjects at } 20 \text { minutes fol- } \\
\text { lowing dosing, by } 11.9 \% \text { of subjects at } \\
40 \text { minutes, and by } 90.1 \% \text { of subjects at } \\
72 \text { hours. }\end{array}$ & $\begin{array}{l}\text { favours intravaginal for individual and } \\
\text { all symptoms combined }\end{array}$ \\
\hline Adetoro 1990 & No specific data reported & & $\begin{array}{l}\text { "The rate or response to treatment sug- } \\
\text { gest that patients } \\
\text { receiving fluconazole (oral) or clotrim- } \\
\text { zole (intravaginal) experienced sympto- } \\
\text { matic } \\
\text { relief after one or two days of treat- } \\
\text { ment, respectively. }\end{array}$ \\
\hline Andersen 1989 & Median time to initial relief & $\begin{array}{l}1 \text { day for fluconazole (oral) and } 2 \\
\text { days for clotrimazole (intravaginal) } \\
(P<0.001) \text {. }\end{array}$ & favors oral \\
\hline Coric 2006 & Proportion of patients at timepoints & $\begin{array}{l}\text { The onset of symptomatic relief in the } \\
\text { first } 24 \mathrm{~h} \text { of treatment was significantly } \\
\text { higher in the fluconazole (oral) ( } 41 \text { out } \\
\text { of } 60 \text { ) than in the clotrimazole (intrav- } \\
\text { aginal) group ( } 9 \text { out of } 59 \text { ). }\end{array}$ & favors oral \\
\hline Mendling 2004 & Median time to initial relief & $\begin{array}{l}\text { Time to first relief was similar in all } \\
\text { three treatment groups }=3 \text { days. }\end{array}$ & no difference \\
\hline Murina 2012 & Mean time to initial relief & $\begin{array}{l}\text { Fenticonazole group }=2.3 \text { days. Flu- } \\
\text { conazole }=4.5 \text { days. }\end{array}$ & $\begin{array}{l}\text { Vulvovaginal pruritus only. } \\
\text { favors intravaginal }\end{array}$ \\
\hline Seidman 2005 & $\begin{array}{l}\text { Median time to initial relief } \\
\text { Proportion of patients at timepoints }\end{array}$ & $\begin{array}{l}\text { Butoconazole (intravaginal) group = } \\
17.5 \text { hours. Fluconazole (oral) group }= \\
22.9 \text { hours. ( } p<0.001 \text { ). } \\
\text { By } 12 \text { - and } 24 \text {-h post-treatment, } 44.4 \% \\
\text { and } 72.8 \% \text { of patients in the butocona- } \\
\text { zole treatment group reported first } \\
\text { relief of symptoms versus } 29.1 \% \text { and } \\
55.7 \% \text { of patients in the fluconazole } \\
\text { group ( } p=0.044 \text { and } p=0.024 \text { respec- } \\
\text { tively). }\end{array}$ & favors intravaginal \\
\hline
\end{tabular}




\begin{tabular}{|c|c|c|c|}
\hline Slavin 1992 & $\begin{array}{l}\text { Median time to initial relief } \\
\text { Mean time to initial relief }\end{array}$ & $\begin{array}{l}\text { Terconazole (intravaginal) median }=1 \text {. } \\
\text { Fluconazole (oral) median }=2 \text {. } \\
\text { Terconazole mean }=1.80(\text { SD 1.87). Flu- } \\
\text { conazole mean }=2.42(\text { SD 1.73). }\end{array}$ & favors intravaginal \\
\hline Timonen 1992a & Proportion of patients at timepoints & $\begin{array}{l}46.8 \% \text { of the miconazole (intravagi- } \\
\text { nal) group had reported alleviation of } \\
\text { symptoms on the first day, compared to } \\
51.9 \% \text { of the fluconazole (oral) group. } \\
97.9 \% \text { of the miconazole group had re- } \\
\text { ported alleviation of symptoms by the } \\
\text { third day, compared to } 85.2 \% \text { of the flu- } \\
\text { conazole group. There was no statisti- } \\
\text { cal difference between the two groups. }\end{array}$ & $\begin{array}{l}\text { alleviation of symptoms favors oral } \\
\text { (day 1) and intravaginal (day 3) }\end{array}$ \\
\hline Tobin 1992 & Mean time to initial relief & $\begin{array}{l}\text { Clotrimazole (intravaginal) group }=5.5 \\
\text { days. Intraconazole (oral) group }=3.8 \\
\text { days. }(p=0.069) \text {. }\end{array}$ & favors oral \\
\hline
\end{tabular}

\section{Comparison 2. Oral versus Intra-vaginal (no. randomised)}

\begin{tabular}{|c|c|c|c|c|}
\hline Outcome or subgroup title & $\begin{array}{l}\text { No. of } \\
\text { studies }\end{array}$ & $\begin{array}{l}\text { No. of } \\
\text { partici- } \\
\text { pants }\end{array}$ & Statistical method & Effect size \\
\hline 2.1 Clinical cure (short term) & 12 & 1630 & Odds Ratio (M-H, Fixed, 95\% Cl) & $1.10[0.88,1.38]$ \\
\hline $\begin{array}{l}\text { 2.1.1 Fluconazole vs Clotrima- } \\
\text { zole }\end{array}$ & 5 & 594 & Odds Ratio (M-H, Fixed, 95\% Cl) & $0.94[0.66,1.35]$ \\
\hline $\begin{array}{l}\text { 2.1.2 Itraconazole vs Clotrima- } \\
\text { zole }\end{array}$ & 2 & 337 & Odds Ratio (M-H, Fixed, 95\% Cl) & $1.50[0.88,2.54]$ \\
\hline 2.1.3 Fluconazole vs Miconazole & 1 & 99 & Odds Ratio (M-H, Fixed, 95\% Cl) & $0.71[0.28,1.76]$ \\
\hline 2.1.4 Fluconazole vs Econazole & 1 & 258 & Odds Ratio (M-H, Fixed, 95\% Cl) & $1.79[0.90,3.59]$ \\
\hline 2.1.5 Itraconazole vs Econazole & 1 & 81 & Odds Ratio (M-H, Fixed, 95\% Cl) & $1.83[0.73,4.56]$ \\
\hline $\begin{array}{l}\text { 2.1.6 Fluconazole vs Butocona- } \\
\text { zole }\end{array}$ & 1 & 181 & Odds Ratio (M-H, Fixed, 95\% Cl) & $0.83[0.46,1.51]$ \\
\hline $\begin{array}{l}\text { 2.1.7 Fluconazole vs Fenticona- } \\
\text { zole }\end{array}$ & 1 & 80 & Odds Ratio (M-H, Fixed, 95\% Cl) & $0.89[0.34,2.33]$ \\
\hline 2.2 Clinical cure (long term) & 8 & 972 & Odds Ratio (M-H, Fixed, 95\% Cl) & $1.17[0.88,1.56]$ \\
\hline 2.2.1 Fluconazole vs Clotrimzole & 3 & 381 & Odds Ratio (M-H, Fixed, 95\% CI) & $1.08[0.68,1.72]$ \\
\hline $\begin{array}{l}\text { 2.2.2 Itraconazole vs Clotrima- } \\
\text { zole }\end{array}$ & 1 & 73 & Odds Ratio (M-H, Fixed, 95\% Cl) & $1.28[0.48,3.44]$ \\
\hline 2.2.3 Fluconazole vs Miconazole & 1 & 99 & Odds Ratio (M-H, Fixed, 95\% Cl) & $0.77[0.30,1.99]$ \\
\hline 2.2.4 Fluconazole vs Econazole & 1 & 258 & Odds Ratio (M-H, Fixed, 95\% Cl) & $1.54[0.93,2.56]$ \\
\hline 2.2.5 Itraconazole vs Econazole & 1 & 81 & Odds Ratio (M-H, Fixed, 95\% Cl) & $0.97[0.34,2.76]$ \\
\hline $\begin{array}{l}\text { 2.2.6 fuconazole vs fenticona- } \\
\text { zole }\end{array}$ & 1 & 80 & Odds Ratio (M-H, Fixed, 95\% Cl) & $0.65[0.10,4.11]$ \\
\hline
\end{tabular}




\begin{tabular}{|c|c|c|c|c|}
\hline Outcome or subgroup title & $\begin{array}{l}\text { No. of } \\
\text { studies }\end{array}$ & $\begin{array}{l}\text { No. of } \\
\text { partici- } \\
\text { pants }\end{array}$ & Statistical method & Effect size \\
\hline $\begin{array}{l}2.3 \text { Mycological cure (short } \\
\text { term) }\end{array}$ & 16 & 2343 & Odds Ratio (M-H, Fixed, 95\% Cl) & $1.16[0.96,1.40]$ \\
\hline $\begin{array}{l}\text { 2.3.1 Fluconazole vs Clotrima- } \\
\text { zole }\end{array}$ & 10 & 1443 & Odds Ratio (M-H, Fixed, 95\% Cl) & $1.02[0.80,1.29]$ \\
\hline $\begin{array}{l}\text { 2.3.2 Itraconazole vs Clotrima- } \\
\text { zole }\end{array}$ & 2 & 337 & Odds Ratio (M-H, Fixed, 95\% Cl) & $1.12[0.65,1.92]$ \\
\hline 2.3.3 Fluconazole vs Miconazole & 2 & 224 & Odds Ratio (M-H, Fixed, 95\% Cl) & $0.85[0.44,1.66]$ \\
\hline 2.3.4 Fluconazole vs Econazole & 1 & 258 & Odds Ratio (M-H, Fixed, 95\% Cl) & $2.01[1.14,3.53]$ \\
\hline 2.3.5 Itraconazole vs Econazole & 1 & 81 & Odds Ratio (M-H, Fixed, 95\% Cl) & $3.47[1.35,8.92]$ \\
\hline 2.4 Mycological cure (long term) & 10 & 1378 & Odds Ratio (M-H, Fixed, 95\% Cl) & $1.35[1.09,1.68]$ \\
\hline $\begin{array}{l}\text { 2.4.1 Fluconazole vs Clotrima- } \\
\text { zole }\end{array}$ & 5 & 742 & Odds Ratio (M-H, Fixed, 95\% Cl) & $1.32[0.99,1.78]$ \\
\hline $\begin{array}{l}\text { 2.4.2 Itraconazole vs Clotrima- } \\
\text { zole }\end{array}$ & 1 & 73 & Odds Ratio (M-H, Fixed, 95\% Cl) & $0.87[0.31,2.44]$ \\
\hline 2.4.3 Fluconazole vs Miconazole & 2 & 224 & Odds Ratio (M-H, Fixed, 95\% Cl) & $0.79[0.45,1.38]$ \\
\hline 2.4.4 Fluconazole vs Econazole & 1 & 258 & Odds Ratio (M-H, Fixed, 95\% Cl) & $2.06[1.26,3.39]$ \\
\hline 2.4.5 Itraconazole vs Econazole & 1 & 81 & Odds Ratio (M-H, Fixed, 95\% Cl) & $2.35[0.96,5.74]$ \\
\hline 2.5 Side effects & 4 & 796 & Odds Ratio (M-H, Fixed, 95\% Cl) & $0.90[0.55,1.50]$ \\
\hline $\begin{array}{l}\text { 2.5.1 Fluconazole vs Clotrima- } \\
\text { zole }\end{array}$ & 1 & 142 & Odds Ratio (M-H, Fixed, 95\% Cl) & $1.67[0.38,7.26]$ \\
\hline $\begin{array}{l}\text { 2.5.2 Itraconazole vs Clotrima- } \\
\text { zole }\end{array}$ & 1 & 264 & Odds Ratio (M-H, Fixed, 95\% Cl) & $0.44[0.16,1.18]$ \\
\hline $\begin{array}{l}\text { 2.5.3 Fluconazole vs Fenticona- } \\
\text { zole }\end{array}$ & 1 & 80 & Odds Ratio (M-H, Fixed, 95\% Cl) & $1.54[0.24,9.75]$ \\
\hline 2.5.4 Fluconazole vs Miconazole & 1 & 310 & Odds Ratio (M-H, Fixed, 95\% Cl) & $1.08[0.53,2.19]$ \\
\hline
\end{tabular}


Analysis 2.1. Comparison 2: Oral versus Intra-vaginal (no. randomised), Outcome 1: Clinical cure (short term)

\begin{tabular}{|c|c|c|c|c|c|c|c|}
\hline & $\mathbf{O}$ & & Intra- & ginal & & Odds Ratio & Odds Ratio \\
\hline Study or Subgroup & Events & Total & Events & Total & Weight & M-H, Fixed, 95\% CI & M-H, Fixed, 95\% CI \\
\hline
\end{tabular}

2.1.1 Fluconazole vs Clotrimazole

Coric 2006

Goode 1992

Sekhavat 2011

Stein 1991

Woolley 1995

Subtotal $(95 \%$ CI $)$

Total events:

Heterogeneity: $\mathrm{Chi}^{2}=9.77, \mathrm{df}=4(\mathrm{P}=0.04) ; \mathrm{I}^{2}=59 \%$

Test for overall effect: $\mathrm{Z}=0.32(\mathrm{P}=0.75)$

2.1.2 Itraconazole vs Clotrimazole

$\begin{array}{lrrrrrr}\text { Sanam } 2009 & 110 & 132 & 103 & 132 & 11.7 \% & 1.41[0.76,2.61] \\ \text { Stein } 1993 & 35 & 50 & 13 & 23 & 3.6 \% & 1.79[0.65,4.99] \\ \text { Subtotal (95\% CI) } & & \mathbf{1 8 2} & & \mathbf{1 5 5} & \mathbf{1 5 . 3 \%} & \mathbf{1 . 5 0}[\mathbf{0 . 8 8}, \mathbf{2 . 5 4}]\end{array}$

Total events:

145

Heterogeneity: $\mathrm{Chi}^{2}=0.16, \mathrm{df}=1(\mathrm{P}=0.69) ; \mathrm{I}^{2}=0 \%$

Test for overall effect: $\mathrm{Z}=1.50(\mathrm{P}=0.13)$

2.1.3 Fluconazole vs Miconazole

Van Heusden 1990

$0.71[0.28,1.76]$

$0.71[0.28,1.76]$

$0.36[0.07,1.91]$

$1.97[0.97,4.00]$

$0.40[0.16,1.00]$

$0.94[0.66,1.35]$
Subtotal (95\% CI)

$35 \quad 49$

Total events:

35

39

39

Heterogeneity: Not applicable

Test for overall effect: $\mathrm{Z}=0.75(\mathrm{P}=0.45)$

\subsubsection{Fluconazole vs Econazole}

113

Subtotal (95\% CI)

$113 \quad 128$

Total events:

113

128

Heterogeneity: Not applicable

Test for overall effect: $\mathrm{Z}=1.65(\mathrm{P}=0.10)$

\subsubsection{Itraconazole vs Econazole}

Timonen 1992b 28

Subtotal (95\% CI)

Total events: 28

Heterogeneity: Not applicable

Test for overall effect: $\mathrm{Z}=1.29(\mathrm{P}=0.20)$

\subsubsection{Fluconazole vs Butoconazole}

Seidman $2005 \quad 33$

Subtotal (95\% CI)

$33 \quad 88$

Total events: 33

Heterogeneity: Not applicable

Test for overall effect: $\mathrm{Z}=0.61(\mathrm{P}=0.54)$

2.1.7 Fluconazole vs Fenticonazole

Murina 2012

Subtotal $(95 \%$ CI $)$

28
40

Total events:

$\begin{array}{llll}88 & 39 & 93 & 16.2 \% \\ \mathbf{8 8} & & \mathbf{9 3} & \mathbf{1 6 . 2 \%}\end{array}$

$0.83[0.46,1.51]$
$\mathbf{0 . 8 3}[\mathbf{0 . 4 6}, \mathbf{1 . 5 1}]$

$0.83[0.46,1.51]$
$\mathbf{0 . 8 3}[\mathbf{0 . 4 6}, \mathbf{1 . 5 1}]$

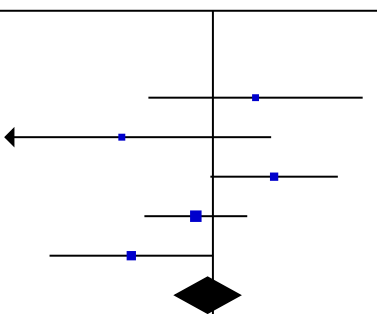

$1.79[0.90,3.59]$

$1.79[0.90,3.59]$

$1.83[0.73,4.56]$

$1.83[0.73,4.56]$

$41 \quad 4.6 \%$

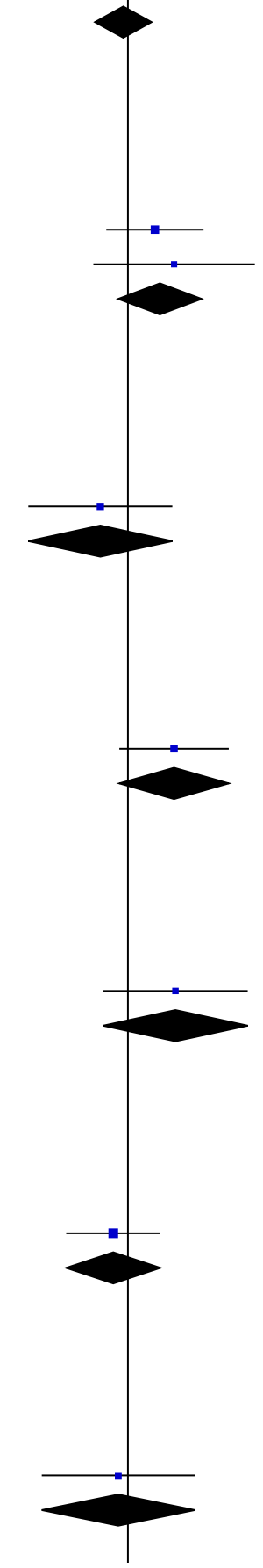

$0.89[0.34,2.33]$

$0.89[0.34,2.33]$ 
Analysis 2.1. (Continued)

\section{Suvtutal (90\% Cl)}

Total events:

28

$\mathbf{4 0}$

Heterogeneity: Not applicable

Test for overall effect: $\mathrm{Z}=0.25(\mathrm{P}=0.80)$

Total (95\% CI)

834

Total events: 592

Heterogeneity: $\mathrm{Chi}^{2}=16.89, \mathrm{df}=11(\mathrm{P}=0.11) ; \mathrm{I}^{2}=35 \%$

Test for overall effect: $\mathrm{Z}=0.84(\mathrm{P}=0.40)$

Test for subgroup differences: $\mathrm{Chi}^{2}=7.08, \mathrm{df}=6(\mathrm{P}=0.31), \mathrm{I}^{2}=15.3 \%$

\section{$796 \quad 100.0 \% \quad 1.10[0.88,1.38]$}

ט.0Y [0.J4, 2.0.J]

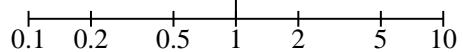

Favours intra-vaginal Favours oral 
Analysis 2.2. Comparison 2: Oral versus Intra-vaginal (no. randomised), Outcome 2: Clinical cure (long term)

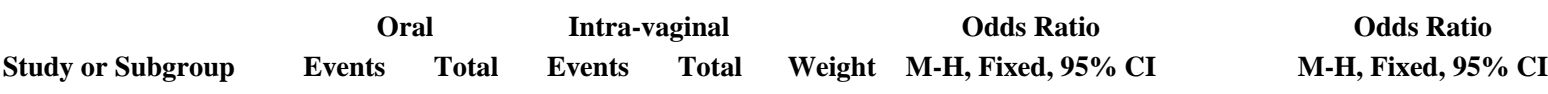

\begin{tabular}{lrrrrrr}
\hline 2.2.1 Fluconazole vs Clotrimzole & & & & & \\
Goode 1992 & 3 & 14 & 4 & 14 & $3.7 \%$ & $0.68[0.12,3.83]$ \\
Stein 1991 & 68 & 111 & 71 & 116 & $31.5 \%$ & $1.00[0.59,1.71]$ \\
Škerk V 2006 & 65 & 71 & 47 & 55 & $5.2 \%$ & $1.84[0.60,5.67]$ \\
Subtotal (95\% CI) & & $\mathbf{1 9 6}$ & & $\mathbf{1 8 5}$ & $\mathbf{4 0 . 4 \%}$ & $\mathbf{1 . 0 8}[\mathbf{0 . 6 8 , 1 . 7 2}]$ \\
Total events: & 136 & & 122 & & &
\end{tabular}

Heterogeneity: $\mathrm{Chi}^{2}=1.22, \mathrm{df}=2(\mathrm{P}=0.54) ; \mathrm{I}^{2}=0 \%$

Test for overall effect: $\mathrm{Z}=0.33(\mathrm{P}=0.74)$

\subsubsection{Itraconazole vs Clotrimazole}

$\begin{array}{lllllll}\text { Stein } 1993 & 27 & 50 & 11 & 23 & 8.1 \% & 1.28[0.48,3.44] \\ \text { Subtotal }(\mathbf{9 5 \%} \text { CI) } & & \mathbf{5 0} & & \mathbf{2 3} & \mathbf{8 . 1 \%} & \mathbf{1 . 2 8}[\mathbf{0 . 4 8}, \mathbf{3 . 4 4}]\end{array}$

Total events: 27

Heterogeneity: Not applicable

Test for overall effect: $\mathrm{Z}=0.49(\mathrm{P}=0.62)$

2.2.3 Fluconazole vs Miconazole

Subtotal (95\% CI)

$37 \quad 49-40$

$50 \quad 11.3 \%$

$0.77[0.30,1.99]$

49

$50 \quad 11.3 \%$

$0.77[0.30,1.99]$

Heterogeneity: Not applicable

Test for overall effect: $\mathrm{Z}=0.54(\mathrm{P}=0.59)$

\subsubsection{Fluconazole vs Econazole}

$\begin{array}{lcccccc}\text { Osser } 1991 & 85 & 128 & 73 & 130 & 28.5 \% & 1.54[0.93,2.56] \\ \text { Subtotal (95\% CI) } & & \mathbf{1 2 8} & & \mathbf{1 3 0} & \mathbf{2 8 . 5 \%} & \mathbf{1 . 5 4}[\mathbf{0 . 9 3}, \mathbf{2 . 5 6}] \\ \text { Total events: } & 85 & & 73 & & & \end{array}$

Heterogeneity: Not applicable

Test for overall effect: $\mathrm{Z}=1.69(\mathrm{P}=0.09)$

2.2.5 Itraconazole vs Econazole

$\begin{array}{lllllll}\text { Timonen } 1992 \mathrm{~b} & 31 & 40 & 32 & 41 & 8.3 \% & 0.97[0.34,2.76] \\ \text { Subtotal }(\mathbf{9 5 \%} \text { CI) } & & \mathbf{4 0} & & \mathbf{4 1} & \mathbf{8 . 3 \%} & \mathbf{0 . 9 7}[\mathbf{0 . 3 4}, \mathbf{2 . 7 6}] \\ \text { Total events: } & 31 & & 32 & & & \end{array}$

Heterogeneity: Not applicable

Test for overall effect: $Z=0.06(P=0.95)$

2.2.6 fuconazole vs fenticonazole

$\begin{array}{llllll}\text { Murina } 2012 & 37 & 40 & 38 & 40 & 3.3 \% \\ \text { Subtotal (95\% CI) } & & \mathbf{4 0} & & \mathbf{4 0} & \mathbf{3 . 3 \%} \\ \text { Total events: } & 37 & & 38 & & \end{array}$

$0.65[0.10,4.11]$

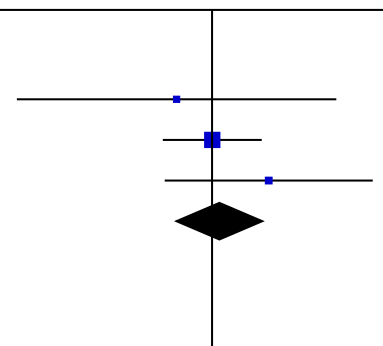

Heterogeneity: Not applicable

Test for overall effect: $\mathrm{Z}=0.46(\mathrm{P}=0.65)$

Total (95\% CI)

503

Total events:

$353 \quad 316$

Heterogeneity: $\mathrm{Chi}^{2}=3.78, \mathrm{df}=7(\mathrm{P}=0.81) ; \mathrm{I}^{2}=0 \%$

Test for overall effect: $\mathrm{Z}=1.07(\mathrm{P}=0.28)$

Test for subgroup differences: $\mathrm{Chi}^{2}=2.56, \mathrm{df}=5(\mathrm{P}=0.77), \mathrm{I}^{2}=0 \%$ $0.65[0.10,4.11]$

$469 \quad 100.0 \%$

$1.17[0.88,1.56]$

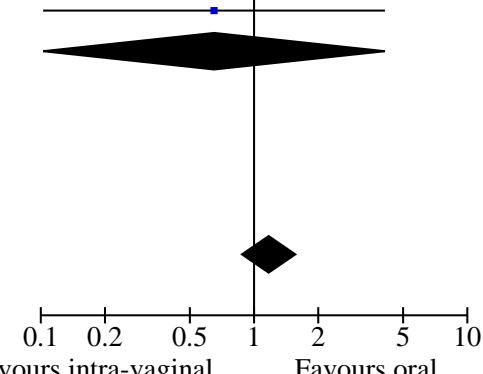


Analysis 2.3. Comparison 2: Oral versus Intra-vaginal (no. randomised), Outcome 3: Mycological cure (short term)

\begin{tabular}{|c|c|c|c|c|c|}
\hline \multirow[b]{2}{*}{ Study or Subgroup } & \multicolumn{2}{|c|}{ Oral } & \multicolumn{2}{|c|}{ Intra-vaginal } & \multirow[b]{2}{*}{ Weight } \\
\hline & Events & Total & Events & Total & \\
\hline \multicolumn{6}{|c|}{ 2.3.1 Fluconazole vs Clotrimazole } \\
\hline Adetoro 1990 & 20 & 23 & 15 & 20 & $1.0 \%$ \\
\hline Andersen 1989 & 143 & 188 & 131 & 181 & $16.0 \%$ \\
\hline Boag 1991 & 10 & 11 & 6 & 11 & $0.3 \%$ \\
\hline Coric 2006 & 33 & 38 & 37 & 46 & $2.2 \%$ \\
\hline Goode 1992 & 2 & 14 & 8 & 14 & $3.4 \%$ \\
\hline Mendling 2004 & 59 & 114 & 129 & 226 & $20.9 \%$ \\
\hline Mikamo 1995 & 38 & 50 & 18 & 25 & $2.9 \%$ \\
\hline Sekhavat 2011 & 60 & 72 & 49 & 70 & $4.1 \%$ \\
\hline Stein 1991 & 80 & 111 & 88 & 116 & $12.0 \%$ \\
\hline Woolley 1995 & 60 & 72 & 39 & 41 & $4.1 \%$ \\
\hline Subtotal (95\% CI) & & 693 & & 750 & $67.0 \%$ \\
\hline Total events: & 505 & & 520 & & \\
\hline
\end{tabular}

Odds Ratio

M-H, Fixed, 95\% CI
Odds Ratio

M-H, Fixed, 95\% CI

Heterogeneity: $\mathrm{Chi}^{2}=18.06, \mathrm{df}=9(\mathrm{P}=0.03) ; \mathrm{I}^{2}=50 \%$

Test for overall effect: $Z=0.14(P=0.89)$

\subsubsection{Itraconazole vs Clotrimazole}

$\begin{array}{lrrrrr}\text { Sanam } 2009 & 110 & 132 & 103 & 132 & 8.6 \% \\ \text { Stein } 1993 & 35 & 50 & 19 & 23 & 3.9 \% \\ \text { Subtotal }(\mathbf{9 5 \%} \text { CI) } & & \mathbf{1 8 2} & & \mathbf{1 5 5} & \mathbf{1 2 . 5 \%} \\ \text { Total events: } & 145 & & 122 & & \end{array}$

Heterogeneity: $\mathrm{Chi}^{2}=2.24, \mathrm{df}=1(\mathrm{P}=0.13) ; \mathrm{I}^{2}=55 \%$

Test for overall effect: $\mathrm{Z}=0.42(\mathrm{P}=0.68)$

2.3.3 Fluconazole vs Miconazole

$\begin{array}{lrrrrr}\text { Timonen 1992a } & 45 & 63 & 42 & 62 & 6.1 \% \\ \text { Van Heusden 1990 } & 42 & 49 & 48 & 50 & 3.4 \% \\ \text { Subtotal (95\% CI) } & & \mathbf{1 1 2} & & \mathbf{1 1 2} & \mathbf{9 . 4 \%}\end{array}$

$1.19[0.56,2.55]$ $0.25[0.05,1.27]$ $0.85[0.44,1.66]$

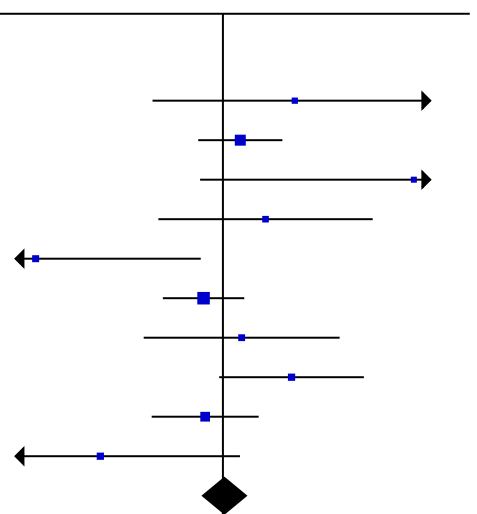

Heterogeneity: $\mathrm{Chi}^{2}=2.92, \mathrm{df}=1(\mathrm{P}=0.09) ; \mathrm{I}^{2}=66 \%$

Test for overall effect: $\mathrm{Z}=0.47(\mathrm{P}=0.64)$

2.3.4 Fluconazole vs Econazole

$\begin{array}{lcccccc}\text { Osser } 1991 & 102 & 128 & 86 & 130 & 8.7 \% & 2.01[1.14,3.53] \\ \text { Subtotal }(\mathbf{9 5 \%} \text { CI) } & & \mathbf{1 2 8} & & \mathbf{1 3 0} & \mathbf{8 . 7 \%} & \mathbf{2 . 0 1}[\mathbf{1 . 1 4}, \mathbf{3 . 5 3}] \\ \text { Total events: } & 102 & & 86 & & & \end{array}$

Heterogeneity: Not applicable

Test for overall effect: $\mathrm{Z}=2.42(\mathrm{P}=0.02)$

2.3.5 Itraconazole vs Econazole

$\begin{array}{lllllll}\text { Timonen } 1992 \mathrm{~b} & 30 & 40 & 19 & 41 & 2.3 \% & 3.47[1.35,8.92] \\ \text { Subtotal }(\mathbf{9 5 \%} \text { CI) } & & \mathbf{4 0} & & \mathbf{4 1} & \mathbf{2 . 3 \%} & \mathbf{3 . 4 7}[\mathbf{1 . 3 5}, \mathbf{8 . 9 2}]\end{array}$

Total events:

Heterogeneity: Not applicable

Test for overall effect: $\mathrm{Z}=2.59(\mathrm{P}=0.010)$

Total $(95 \%$ CI)

1155

Total events: 869 837

Heterogeneity: $\mathrm{Chi}^{2}=33.48, \mathrm{df}=15(\mathrm{P}=0.004) ; \mathrm{I}^{2}=55 \%$

Test for overall effect: $\mathrm{Z}=1.52(\mathrm{P}=0.13)$

Test for subgroup differences: $\mathrm{Chi}^{2}=10.84, \mathrm{df}=4(\mathrm{P}=0.03), \mathrm{I}^{2}=63.1 \%$
$1.41[0.76,2.61]$ $0.49[0.14,1.69]$ $1.12[0.65,1.92]$ $8.33[0.78,89.47]$

$1.61[0.49,5.28]$

$1.23[0.41,3.65]$

$2.14[0.96,4.79]$

$0.82[0.45,1.49]$

$0.26[0.05,1.21]$

$1.02[0.80,1.29]$

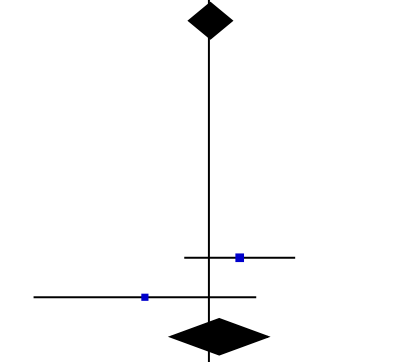

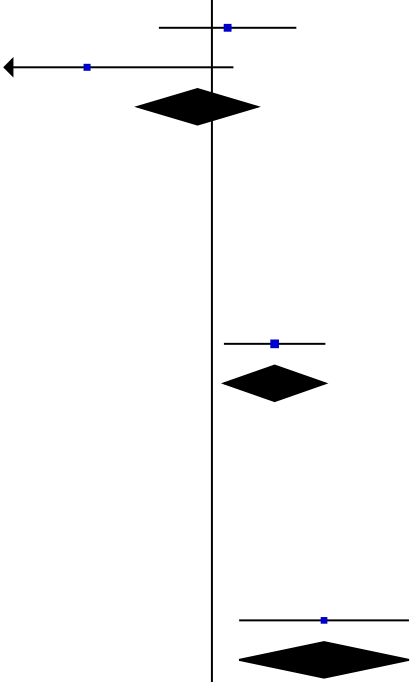

$1188 \quad 100.0 \%$

$1.16[0.96,1.40]$

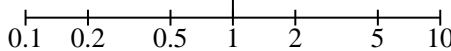

Favours intra-vaginal Favours oral 
Analysis 2.3. (Continued)

lest ior overan enect: $\angle=1 . J \angle(r=0.10)$ 
Analysis 2.4. Comparison 2: Oral versus Intra-vaginal (no. randomised), Outcome 4: Mycological cure (long term)

Oral
Intra-vaginal

Study or Subgroup

\subsubsection{Fluconazole vs Clotrimazole}

Adetoro 1990

Andersen 1989

Goode 1992

Mikamo 1995

Stein 1991

Subtotal (95\% CI)

Total events:

Heterogeneity: $\mathrm{Chi}^{2}=6.57, \mathrm{df}=4(\mathrm{P}=0.16) ; \mathrm{I}^{2}=39 \%$

Test for overall effect: $\mathrm{Z}=1.87(\mathrm{P}=0.06)$

\subsubsection{Itraconazole vs Clotrimazole}

Stein 1993

\section{Subtotal (95\% CI)}

$31 \quad 50$

$50 \quad 15$

Total events:

31
Odds Ratio

Weight M-H, Fixed, 95\% CI
Odds Ratio

M-H, Fixed, $95 \%$ CI

Heterogeneity: Not applicable

Test for overall effect: $\mathrm{Z}=0.26(\mathrm{P}=0.79)$

\subsubsection{Fluconazole vs Miconazole}

$\begin{array}{lrrrrrr}\text { Timonen 1992a } & 39 & 63 & 36 & 62 & 9.8 \% & 1.17[0.57,2.40] \\ \text { Van Heusden 1990 } & 32 & 49 & 41 & 50 & 10.0 \% & 0.41[0.16,1.05] \\ \text { Subtotal (95\% CI) } & & \mathbf{1 1 2} & & \mathbf{1 1 2} & \mathbf{1 9 . 9 \%} & \mathbf{0 . 7 9}[\mathbf{0 . 4 5}, \mathbf{1 . 3 8}]\end{array}$

$4.44[0.98,20.07]$

$1.59[1.05,2.41]$

$0.68[0.12,3.83]$

$1.56[0.57,4.24]$

$0.86[0.51,1.45]$

$1.32[0.99,1.78]$

71

Heterogeneity: $\mathrm{Chi}^{2}=3.04, \mathrm{df}=1(\mathrm{P}=0.08) ; \mathrm{I}^{2}=67 \%$

Test for overall effect: $\mathrm{Z}=0.83(\mathrm{P}=0.41)$

\subsubsection{Fluconazole vs Econazole}

$\begin{array}{lllllll}\text { Osser } 1991 & 79 & 128 & 57 & 130 & 15.4 \% & 2.06[1.26,3.39] \\ \text { Subtotal }(\mathbf{9 5 \%} \text { CI) } & & \mathbf{1 2 8} & & \mathbf{1 3 0} & \mathbf{1 5 . 4 \%} & \mathbf{2 . 0 6}[\mathbf{1 . 2 6}, \mathbf{3 . 3 9}]\end{array}$

$0.87[0.31,2.44]$

$0.87[0.31,2.44]$

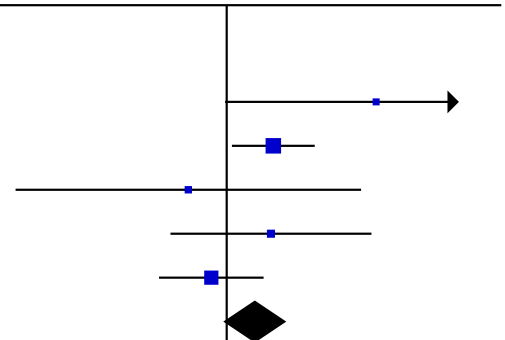

Total events:

79

57

Heterogeneity: Not applicable

Test for overall effect: $\mathrm{Z}=2.86(\mathrm{P}=0.004)$

\subsubsection{Itraconazole vs Econazole}

Timonen 1992b 25

Subtotal (95\% CI)

$25 \quad 40$

$41 \quad 4.5 \%$

$2.35[0.96,5.74]$

25

40

Heterogeneity: Not applicable

Test for overall effect: $\mathrm{Z}=1.88(\mathrm{P}=0.06)$

\section{Total (95\% CI)}

Total events:

436

Heterogeneity: $\mathrm{Chi}^{2}=17.95, \mathrm{df}=9(\mathrm{P}=0.04) ; \mathrm{I}^{2}=50 \%$

Test for overall effect: $\mathrm{Z}=2.73(\mathrm{P}=0.006)$

Test for subgroup differences: $\mathrm{Chi}^{2}=8.57, \mathrm{df}=4(\mathrm{P}=0.07), \mathrm{I}^{2}=53.3 \%$
$662100.0 \%$

$1.35[1.09,1.68]$

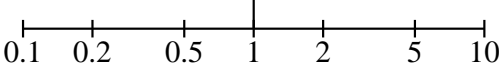

Favours intra-vaginal

Favours oral

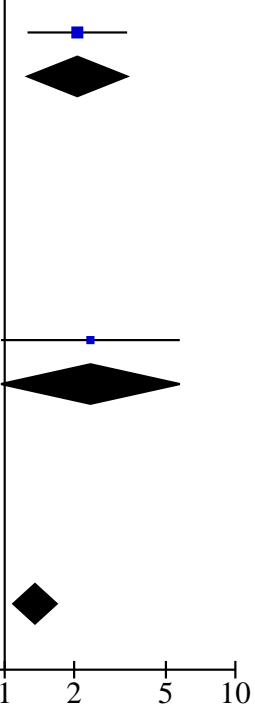


Analysis 2.5. Comparison 2: Oral versus Intra-vaginal (no. randomised), Outcome 5: Side effects

\begin{tabular}{|c|c|c|c|c|c|c|c|}
\hline \multirow{2}{*}{ Study or Subgroup } & \multicolumn{2}{|c|}{ Oral } & \multicolumn{2}{|c|}{ Intra-vaginal } & \multirow[b]{2}{*}{ Weight } & \multirow{2}{*}{$\begin{array}{c}\text { Odds Ratio } \\
\text { M-H, Fixed, 95\% CI }\end{array}$} & \multirow{2}{*}{$\begin{array}{c}\text { Odds Ratio } \\
\text { M-H, Fixed, } 95 \% \text { CI }\end{array}$} \\
\hline & Events & Total & Events & Total & & & \\
\hline \multicolumn{8}{|c|}{ 2.5.1 Fluconazole vs Clotrimazole } \\
\hline Sekhavat 2011 & 5 & 72 & 3 & 70 & $8.9 \%$ & $1.67[0.38,7.26]$ & 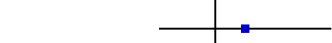 \\
\hline Subtotal $(95 \%$ CI) & & 72 & & 70 & $8.9 \%$ & $1.67[0.38,7.26]$ & \\
\hline Total events: & 5 & & 3 & & & & \\
\hline \multicolumn{8}{|c|}{ Heterogeneity: Not applicable } \\
\hline \multicolumn{8}{|c|}{ Test for overall effect: $\mathrm{Z}=0.68(\mathrm{P}=0.50)$} \\
\hline \multicolumn{8}{|c|}{ 2.5.2 Itraconazole vs Clotrimazole } \\
\hline Sanam 2009 & 6 & 132 & 13 & 132 & $39.2 \%$ & $0.44[0.16,1.18]$ & \\
\hline Subtotal (95\% CI) & & 132 & & 132 & $39.2 \%$ & $0.44[0.16,1.18]$ & \\
\hline Total events: & 6 & & 13 & & & & \\
\hline \multicolumn{8}{|c|}{ Heterogeneity: Not applicable } \\
\hline \multicolumn{8}{|c|}{ Test for overall effect: $\mathrm{Z}=1.63(\mathrm{P}=0.10)$} \\
\hline \multicolumn{8}{|c|}{ 2.5.3 Fluconazole vs Fenticonazole } \\
\hline Murina 2012 & 3 & 40 & 2 & 40 & $5.8 \%$ & $1.54[0.24,9.75]$ & \\
\hline Subtotal $(95 \%$ CI) & & 40 & & 40 & $5.8 \%$ & $1.54[0.24,9.75]$ & \\
\hline Total events: & 3 & & 2 & & & & \\
\hline \multicolumn{8}{|c|}{ Heterogeneity: Not applicable } \\
\hline \multicolumn{8}{|c|}{ Test for overall effect: $\mathrm{Z}=0.46(\mathrm{P}=0.65)$} \\
\hline \multicolumn{8}{|c|}{ 2.5.4 Fluconazole vs Miconazole } \\
\hline ACCELERATE 2002 & 17 & 150 & 17 & 160 & $46.0 \%$ & $1.08[0.53,2.19]$ & \\
\hline Subtotal (95\% CI) & & 150 & & 160 & $46.0 \%$ & $1.08[0.53,2.19]$ & \\
\hline Total events: & 17 & & 17 & & & & \\
\hline \multicolumn{8}{|c|}{ Heterogeneity: Not applicable } \\
\hline \multicolumn{8}{|c|}{ Test for overall effect: $\mathrm{Z}=0.20(\mathrm{P}=0.84)$} \\
\hline Total $(95 \%$ CI $)$ & & 394 & & 402 & $100.0 \%$ & $0.90[0.55,1.50]$ & \\
\hline Total events: & 31 & & 35 & & & & \\
\hline \multicolumn{7}{|c|}{ Heterogeneity: $\mathrm{Chi}^{2}=3.26, \mathrm{df}=3(\mathrm{P}=0.35) ; \mathrm{I}^{2}=8 \%$} & $\begin{array}{ll}1 & 1 \\
0.05 & 0.2\end{array}$ \\
\hline Test for overall effect: & $=0.39(\mathrm{P}=$ & $0.70)$ & & & & & Favours oral \\
\hline
\end{tabular}

Test for subgroup differences: $\mathrm{Chi}^{2}=3.26, \mathrm{df}=3(\mathrm{P}=0.35), \mathrm{I}^{2}=7.9 \%$

Comparison 3. Single-dose oral therapy versus 3 days intra-vaginal therapy

\begin{tabular}{lllll}
\hline Outcome or subgroup title & $\begin{array}{l}\text { No. of } \\
\text { studies }\end{array}$ & $\begin{array}{l}\text { No. of } \\
\text { partici- } \\
\text { pants }\end{array}$ & Statistical method & Effect size \\
\hline 3.1 Mycological cure (short term) & 4 & 618 & Odds Ratio (M-H, Fixed, 95\% Cl) & $1.11[0.73,1.69]$ \\
\hline 3.2 Mycological cure (long term) & 3 & 509 & Odds Ratio (M-H, Fixed, 95\% Cl) & $1.19[0.82,1.73]$ \\
\hline
\end{tabular}




\section{Analysis 3.1. Comparison 3: Single-dose oral therapy versus 3 days} intra-vaginal therapy, Outcome 1: Mycological cure (short term)

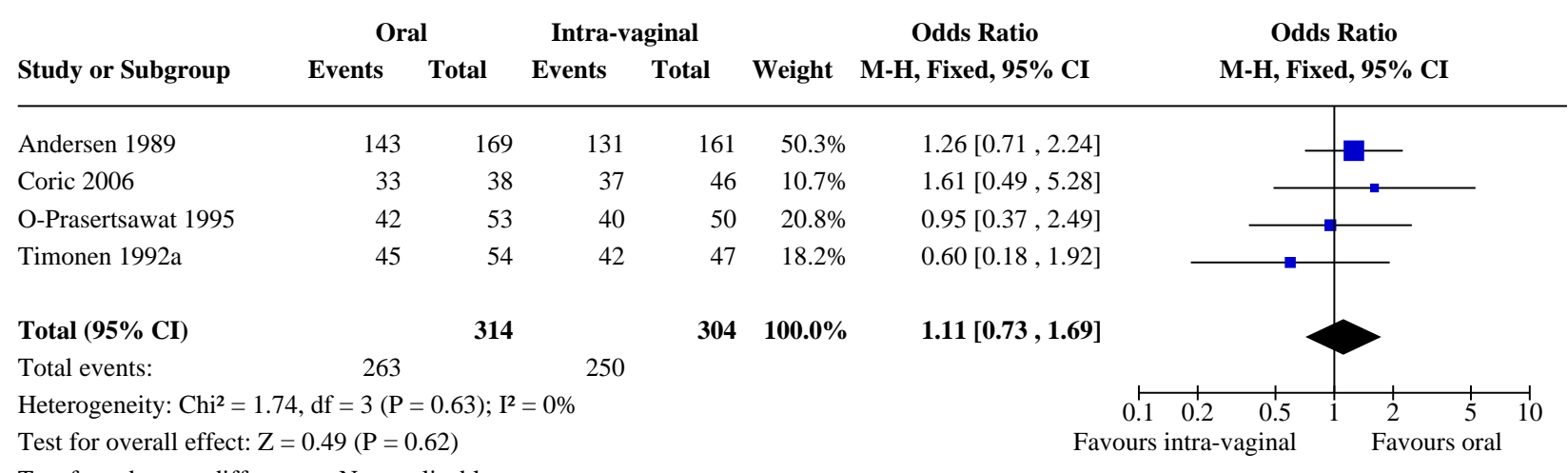

Test for subgroup differences: Not applicable

\section{Analysis 3.2. Comparison 3: Single-dose oral therapy versus 3 days intra-vaginal therapy, Outcome 2: Mycological cure (long term)}

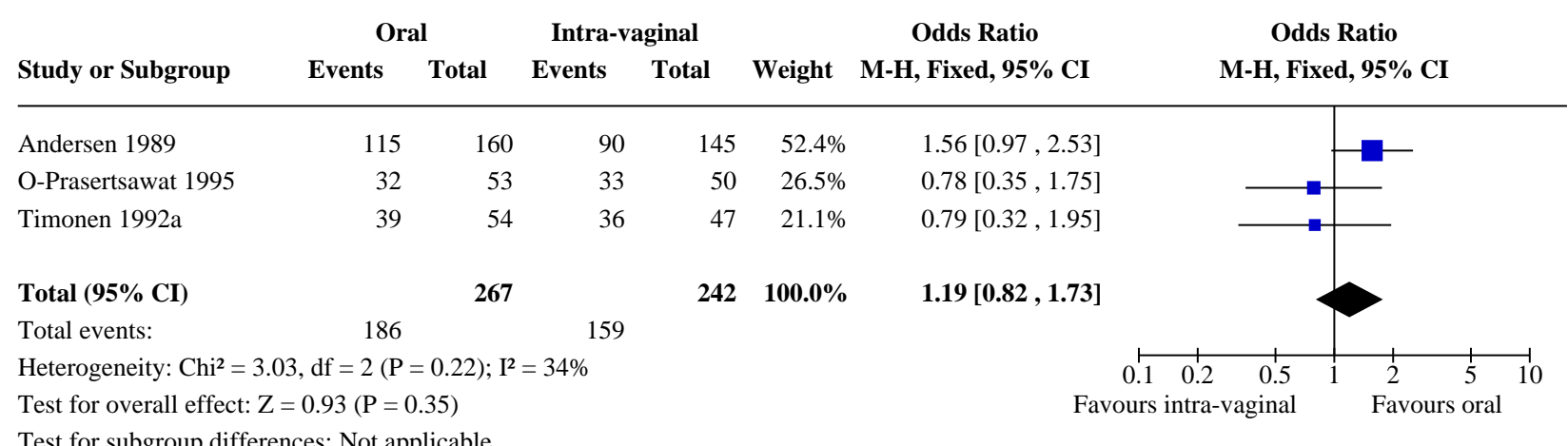

Comparison 4. Single-dose oral anti-fungal therapy versus single-dose intra-vaginal anti-fungal therapy

\begin{tabular}{|c|c|c|c|c|}
\hline Outcome or subgroup title & $\begin{array}{l}\text { No. of } \\
\text { studies }\end{array}$ & $\begin{array}{l}\text { No. of } \\
\text { partici- } \\
\text { pants }\end{array}$ & Statistical method & Effect size \\
\hline 4.1 Clinical cure (short term) & 4 & 572 & Odds Ratio (M-H, Fixed, 95\% Cl) & $0.74[0.48,1.14]$ \\
\hline 4.1.1 Fluconazole vs Clotrimazole & 1 & 113 & Odds Ratio (M-H, Fixed, 95\% Cl) & $0.40[0.16,1.00]$ \\
\hline 4.1.2 Fluconazole vs Miconazole & 1 & 93 & Odds Ratio (M-H, Fixed, 95\% Cl) & $1.23[0.45,3.42]$ \\
\hline 4.1.3 Fluconazole vs Econazole & 1 & 230 & Odds Ratio (M-H, Fixed, 95\% Cl) & $1.51[0.46,4.89]$ \\
\hline $\begin{array}{l}\text { 4.1.4 Fluconazole vs Butocona- } \\
\text { zole }\end{array}$ & 1 & 136 & Odds Ratio (M-H, Fixed, 95\% Cl) & $0.66[0.33,1.30]$ \\
\hline 4.2 Clinical cure (long term) & 2 & 270 & Odds Ratio (M-H, Fixed, 95\% Cl) & $1.24[0.60,2.54]$ \\
\hline 4.2.1 Fluconazole vs Miconazole & 1 & 93 & Odds Ratio (M-H, Fixed, 95\% Cl) & $1.54[0.51,4.66]$ \\
\hline
\end{tabular}




\begin{tabular}{lllll}
\hline Outcome or subgroup title & $\begin{array}{l}\text { No. of } \\
\text { studies }\end{array}$ & $\begin{array}{l}\text { No. of } \\
\text { partici- } \\
\text { pants }\end{array}$ & Statistical method & Effect size \\
\hline 4.2.2 Fluconazole vs Econazole & 1 & 177 & Odds Ratio (M-H, Fixed, 95\% Cl) & $1.05[0.40,2.72]$ \\
\hline 4.3 Mycological cure (short term) & 6 & 737 & Odds Ratio (M-H, Fixed, 95\% Cl) & $1.16[0.77,1.74]$ \\
\hline 4.3.1 Fluconazole vs Clotrimazole & 4 & 414 & Odds Ratio (M-H, Fixed, 95\% Cl) & $0.84[0.50,1.42]$ \\
\hline 4.3.2 Fluconazole vs Miconazole & 1 & 93 & Odds Ratio (M-H, Fixed, 95\% Cl) & $1.75[0.15,20.00]$ \\
\hline 4.3.3 Fluconazole vs Econazole & 1 & 230 & Odds Ratio (M-H, Fixed, 95\% Cl) & $1.93[0.97,3.83]$ \\
\hline
\end{tabular}

\section{Analysis 4.1. Comparison 4: Single-dose oral anti-fungal therapy versus single- dose intra-vaginal anti-fungal therapy, Outcome 1: Clinical cure (short term)}

\begin{tabular}{|c|c|c|c|c|c|c|c|}
\hline \multirow{2}{*}{ Study or Subgroup } & \multicolumn{2}{|c|}{ Oral } & \multicolumn{2}{|c|}{ Intra-vaginal } & \multicolumn{2}{|r|}{ Odds Ratio } & Odds Ratio \\
\hline & Events & Total & Events & Total & Weight & M-H, Fixed, 95\% CI & M-H, Fixed, 95\% CI \\
\hline
\end{tabular}

4.1.1 Fluconazole vs Clotrimazole

Woolley 1995

Subtotal (95\% CI)

Total events: $\quad 45$

Heterogeneity: Not applicable

Test for overall effect: $\mathrm{Z}=1.96(\mathrm{P}=0.05)$

\subsubsection{Fluconazole vs Miconazole}

Van Heusden $1990 \quad 35$

Subtotal $(95 \%$ CI $)$

$35 \quad 43$

Total events:

35

Heterogeneity: Not applicable

Test for overall effect: $Z=0.40(P=0.69)$

4.1.3 Fluconazole vs Econazole

Osser 1991

Subtotal (95\% CI)

$113 \quad 118$

Total events:

113

118

105

$1129.6 \%$

$1.51[0.46,4.89]$

Heterogeneity: Not applicable

Test for overall effect: $\mathrm{Z}=0.68(\mathrm{P}=0.50)$

4.1.4 Fluconazole vs Butoconazole

Seidman $2005 \quad 33$

Subtotal (95\% CI)

Total events:

33

$0.66[0.33,1.30]$

$67 \quad 43.3 \%$

$0.66[0.33,1.30]$

Heterogeneity: Not applicable

Test for overall effect: $\mathrm{Z}=1.21(\mathrm{P}=0.23)$

Total (95\% CI)

302

Total events:

$226 \quad 216$

Heterogeneity: $\mathrm{Chi}^{2}=4.19, \mathrm{df}=3(\mathrm{P}=0.24) ; \mathrm{I}^{2}=28 \%$

Test for overall effect: $\mathrm{Z}=1.38(\mathrm{P}=0.17)$

Test for subgroup differences: $\mathrm{Chi}^{2}=4.19$, $\mathrm{df}=3(\mathrm{P}=0.24), \mathrm{I}^{2}=28.4 \%$

39

105

$1.51[0.46,4.89]$

$270 \quad 100.0 \% \quad 0.74[0.48,1.14]$
$0.40[0.16,1.00]$

$0.40[0.16,1.00]$

$1.23[0.45,3.42]$

$1.23[0.45,3.42]$

$\longrightarrow$
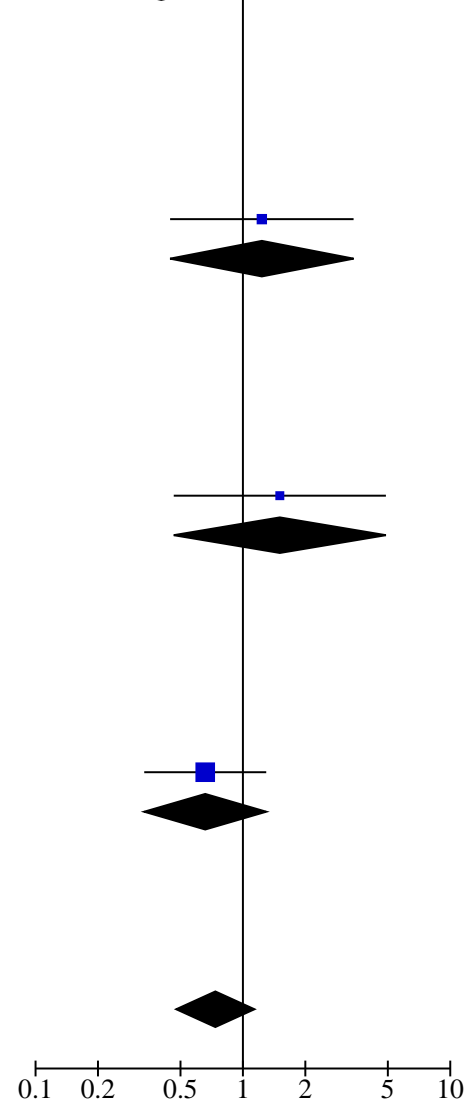

Favours intra-vaginal Favours oral 
Analysis 4.2. Comparison 4: Single-dose oral anti-fungal therapy versus singledose intra-vaginal anti-fungal therapy, Outcome 2: Clinical cure (long term)

\begin{tabular}{|c|c|c|c|c|c|c|c|}
\hline \multirow[b]{2}{*}{ y or Subgroup } & \multicolumn{2}{|c|}{ Oral } & Intra- & ginal & \multicolumn{2}{|r|}{ Odds Ratio } & Odds Ratio \\
\hline & Events & Total & Events & Total & Weight & M-H, Fixed, 95\% CI & M-H, Fixed, 95\% CI \\
\hline
\end{tabular}

4.2.1 Fluconazole vs Miconazole

Van Heusden 1990

Subtotal $(95 \%$ CI $)$

$37 \quad 43$

$43 \quad 40$

0

$50 \quad 38.5 \%$

$1.54[0.51,4.66]$

Total events: $\quad 37$

43

$50 \quad 38.5 \%$

$1.54[0.51,4.66]$

Heterogeneity: Not applicable

Test for overall effect: $\mathrm{Z}=0.77(\mathrm{P}=0.44)$

4.2.2 Fluconazole vs Econazole

Osser 1991

85

95

40

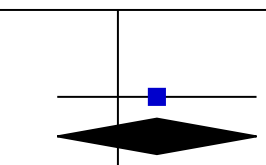

Subtotal (95\% CI)

95

73

$82 \quad 61.5 \%$

$1.05[0.40,2.72]$

Total events:

85

$82 \quad 61.5 \%$

$1.05[0.40,2.72]$

Heterogeneity: Not applicable

Test for overall effect: $\mathrm{Z}=0.10(\mathrm{P}=0.92)$

Total (95\% CI)

138

$132 \quad 100.0 \%$

$1.24[0.60,2.54]$

Total events: 122 113

Heterogeneity: $\mathrm{Chi}^{2}=0.27, \mathrm{df}=1(\mathrm{P}=0.60) ; \mathrm{I}^{2}=0 \%$

Test for overall effect: $\mathrm{Z}=0.58(\mathrm{P}=0.56)$

Test for subgroup differences: $\mathrm{Chi}^{2}=0.27, \mathrm{df}=1(\mathrm{P}=0.60), \mathrm{I}^{2}=0 \%$ 
Analysis 4.3. Comparison 4: Single-dose oral anti-fungal therapy versus singledose intra-vaginal anti-fungal therapy, Outcome 3: Mycological cure (short term)

\begin{tabular}{|c|c|c|c|c|c|c|c|}
\hline & & & Intra & ginal & & Odds Ratio & Odds Ratio \\
\hline Study or Subgroup & Events & Total & Events & Total & Weight & M-H, Fixed, 95\% CI & M-H, Fixed, 95\% CI \\
\hline
\end{tabular}

4.3.1 Fluconazole vs Clotrimazole Adetoro $1990 \quad 20$

Boag 1991

Mendling 2004

Woolley 1995

Subtotal (95\% CI)

$\begin{array}{ll}20 & 23 \\ 10 & 11\end{array}$

15

15

6
129

59
60

Total events:

149

189

Heterogeneity: $\mathrm{Chi}^{2}=5.70, \mathrm{df}=3(\mathrm{P}=0.13) ; \mathrm{I}^{2}=47 \%$

Test for overall effect: $\mathrm{Z}=0.65(\mathrm{P}=0.52)$

4.3.2 Fluconazole vs Miconazole

$\begin{array}{lllllll}\text { Van Heusden } 1990 & 42 & 43 & 48 & 50 & 2.4 \% & 1.75[0.15,20.00] \\ \text { Subtotal (95\% CI) } & & \mathbf{4 3} & & \mathbf{5 0} & \mathbf{2 . 4 \%} & \mathbf{1 . 7 5}[\mathbf{0 . 1 5}, \mathbf{2 0 . 0 0}] \\ \text { Total events: } & 42 & & 48 & & & \end{array}$

Heterogeneity: Not applicable

Test for overall effect: $\mathrm{Z}=0.45(\mathrm{P}=0.65)$

4.3.3 Fluconazole vs Econazole

$\begin{array}{lcccccc}\text { Osser } 1991 & 102 & 118 & 86 & 112 & 27.5 \% & 1.93[0.97,3.83] \\ \text { Subtotal (95\% CI) } & & \mathbf{1 1 8} & & \mathbf{1 1 2} & \mathbf{2 7 . 5 \%} & \mathbf{1 . 9 3}[\mathbf{0 . 9 7}, \mathbf{3 . 8 3}] \\ \text { Total events: } & 102 & & 86 & & & \end{array}$

Heterogeneity: Not applicable

Test for overall effect: $\mathrm{Z}=1.88(\mathrm{P}=0.06)$

Total (95\% CI)

344

Total events:

293

Heterogeneity: $\mathrm{Chi}^{2}=8.97, \mathrm{df}=5(\mathrm{P}=0.11) ; \mathrm{I}^{2}=44 \%$

Test for overall effect: $\mathrm{Z}=0.72(\mathrm{P}=0.47)$

Test for subgroup differences: $\mathrm{Chi}^{2}=3.67, \mathrm{df}=2(\mathrm{P}=0.16), \mathrm{I}^{2}=45.5 \%$

20
9
$1.4 \%$

$2.22[0.46,10.79]$

$161 \quad 44.9 \%$

$5.00[0.42,59.66]$

$0.81[0.42,1.56]$

$0.26[0.05,1.21]$

$231 \quad 70.1 \%$

$393 \quad 100.0 \% \quad 1.16[0.77,1.74]$

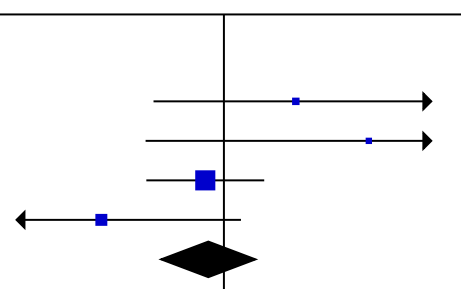

Comparison 5. Single-dose oral therapy versus 6-7 day intra-vaginal therapy

\begin{tabular}{lllll}
\hline Outcome or subgroup title & $\begin{array}{l}\text { No. of } \\
\text { studies }\end{array}$ & $\begin{array}{l}\text { No. of } \\
\text { partici- } \\
\text { pants }\end{array}$ & Statistical method & Effect size \\
\hline 5.1 Clinical cure (short term) & 3 & 427 & Odds Ratio (M-H, Fixed, 95\% Cl) & $1.57[1.03,2.42]$ \\
\hline 5.2 Clinical cure (long term) & 2 & 266 & Odds Ratio (M-H, Fixed, 95\% Cl) & $0.99[0.54,1.83]$ \\
\hline 5.3 Mycological cure (short term) & 4 & 527 & Odds Ratio (M-H, Fixed, 95\% Cl) & $1.47[0.97,2.21]$ \\
\hline 5.4 Mycological cure (long term) & 3 & 366 & Odds Ratio (M-H, Fixed, 95\% Cl) & $1.36[0.88,2.10]$ \\
\hline 5.5 Side effects & 1 & 142 & Odds Ratio (M-H, Fixed, 95\% Cl) & $1.67[0.38,7.26]$ \\
\hline
\end{tabular}




\section{Analysis 5.1. Comparison 5: Single-dose oral therapy versus 6-7} day intra-vaginal therapy, Outcome 1: Clinical cure (short term)

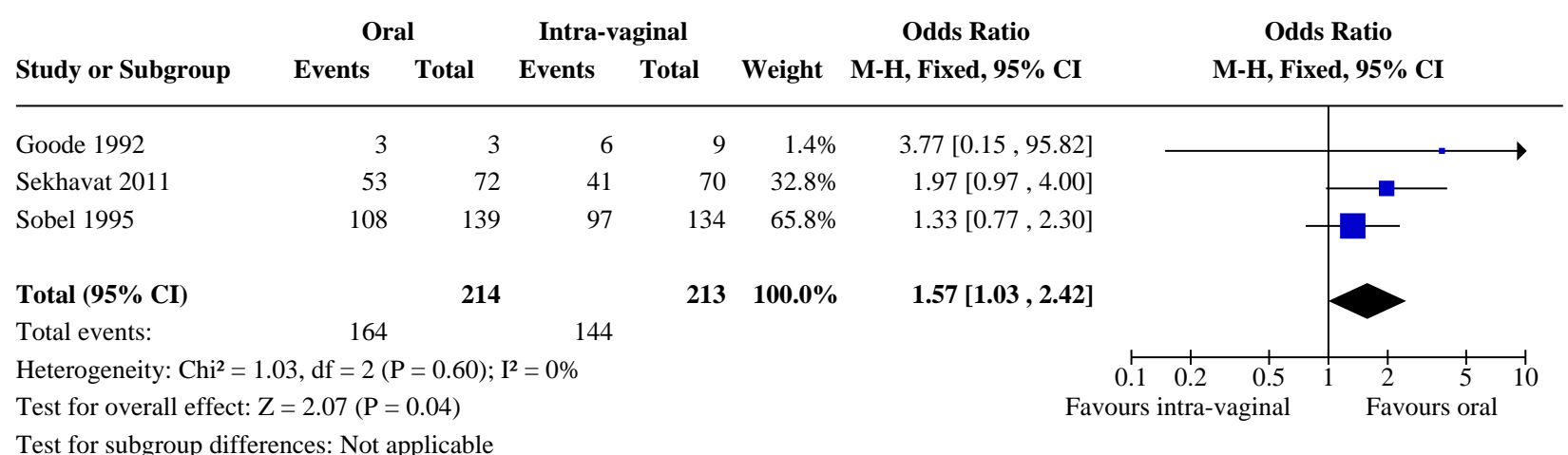

\section{Analysis 5.2. Comparison 5: Single-dose oral therapy versus 6-7} day intra-vaginal therapy, Outcome 2: Clinical cure (long term)

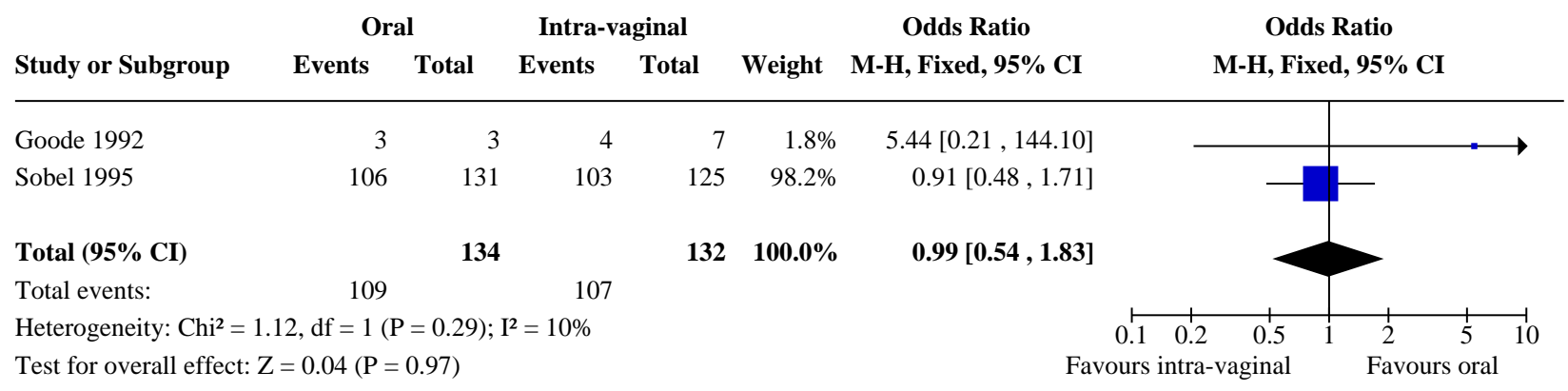

Test for subgroup differences: Not applicable

Analysis 5.3. Comparison 5: Single-dose oral therapy versus 6-7 day intra-vaginal therapy, Outcome 3: Mycological cure (short term)

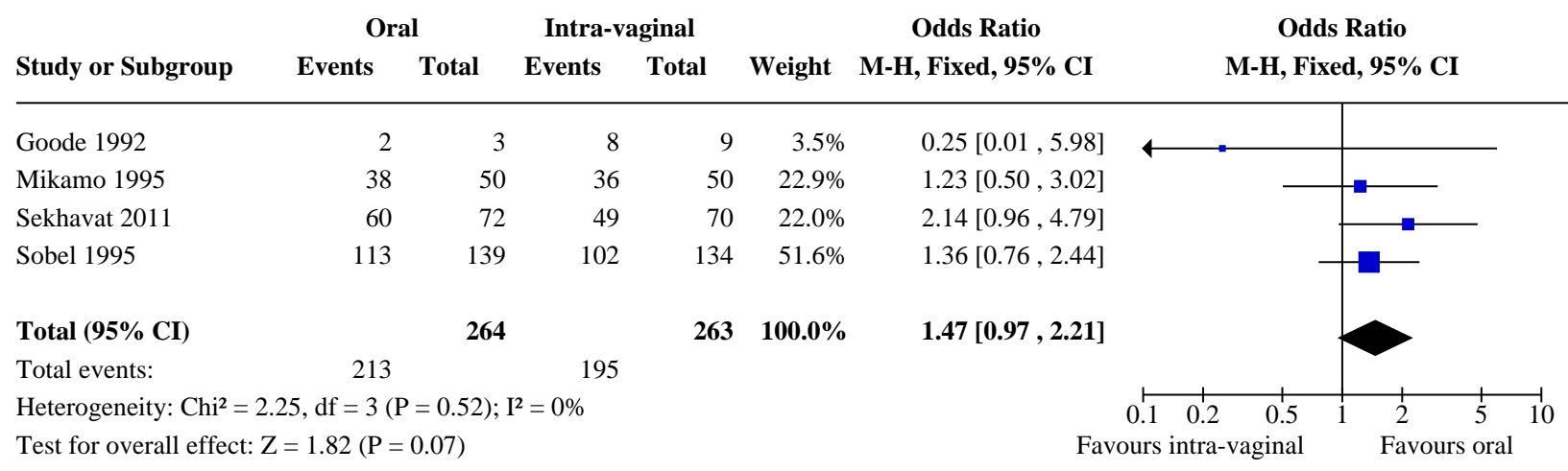


Analysis 5.4. Comparison 5: Single-dose oral therapy versus 6-7 day intra-vaginal therapy, Outcome 4: Mycological cure (long term)

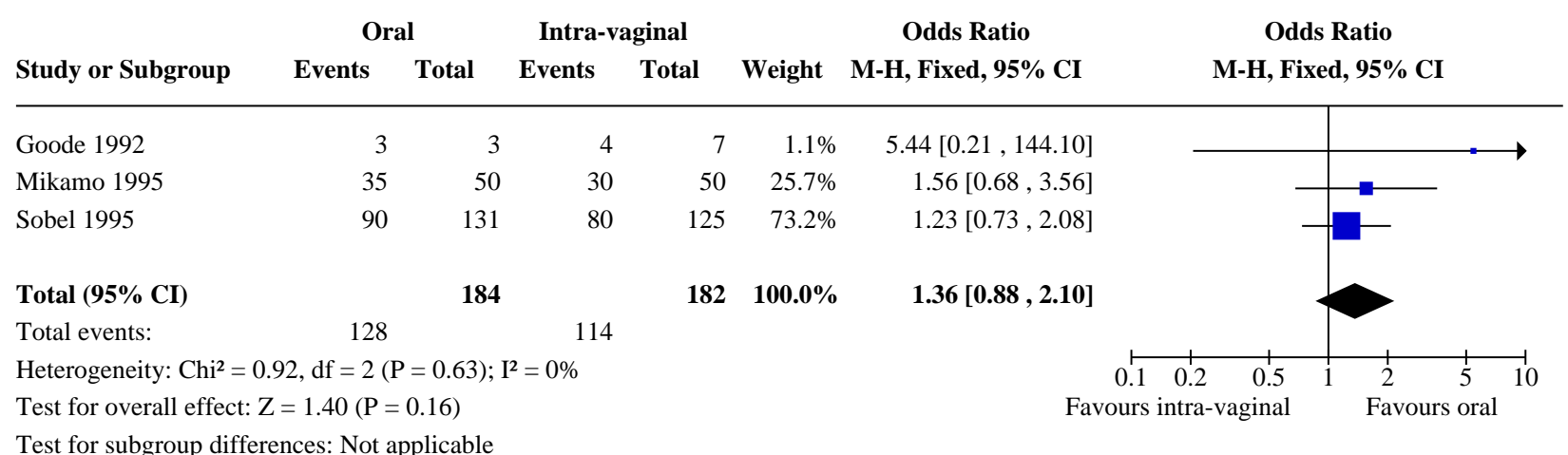

Analysis 5.5. Comparison 5: Single-dose oral therapy versus 6-7 day intra-vaginal therapy, Outcome 5: Side effects

\begin{tabular}{|c|c|c|c|c|c|c|c|}
\hline \multirow[b]{2}{*}{ Study or Subgroup } & \multicolumn{2}{|c|}{ Oral } & \multicolumn{2}{|c|}{ Intra-vaginal } & \multirow[b]{2}{*}{ Weight } & \multirow{2}{*}{$\begin{array}{c}\text { Odds Ratio } \\
\text { M-H, Fixed, 95\% CI }\end{array}$} & \multirow{2}{*}{$\begin{array}{c}\text { Odds Ratio } \\
\text { M-H, Fixed, 95\% CI }\end{array}$} \\
\hline & Events & Total & Events & Total & & & \\
\hline Sekhavat 2011 & 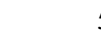 & 72 & 3 & 70 & $100.0 \%$ & $1.67[0.38,7.26]$ & \\
\hline Total $(95 \%$ CI $)$ & & 72 & & 70 & $100.0 \%$ & $1.67[0.38,7.26]$ & \\
\hline Total events: & 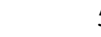 & & 3 & & & & \\
\hline \multirow{2}{*}{\multicolumn{3}{|c|}{$\begin{array}{l}\text { Heterogeneity: Not applicable } \\
\text { Test for overall effect: } \mathrm{Z}=0.68(\mathrm{P}=0.50)\end{array}$}} & & & & & $\begin{array}{ll}0.01 & 0.1\end{array}$ \\
\hline & & & & & & & Favours intra-vagina \\
\hline
\end{tabular}

\section{Comparison 6. Fluconazole versus Clotrimazole}

\begin{tabular}{lllll}
\hline Outcome or subgroup title & $\begin{array}{l}\text { No. of } \\
\text { studies }\end{array}$ & $\begin{array}{l}\text { No. of } \\
\text { partici- } \\
\text { pants }\end{array}$ & Statistical method & Effect size \\
\hline 6.1 Long term clinical cure & 3 & 438 & Odds Ratio (M-H, Fixed, 95\% Cl) & $0.91[0.56,1.46]$ \\
\hline 6.2 Long term mycological cure & 7 & 940 & Odds Ratio (M-H, Fixed, 95\% Cl) & $1.25[0.94,1.65]$ \\
\hline
\end{tabular}


Analysis 6.1. Comparison 6: Fluconazole versus Clotrimazole, Outcome 1: Long term clinical cure

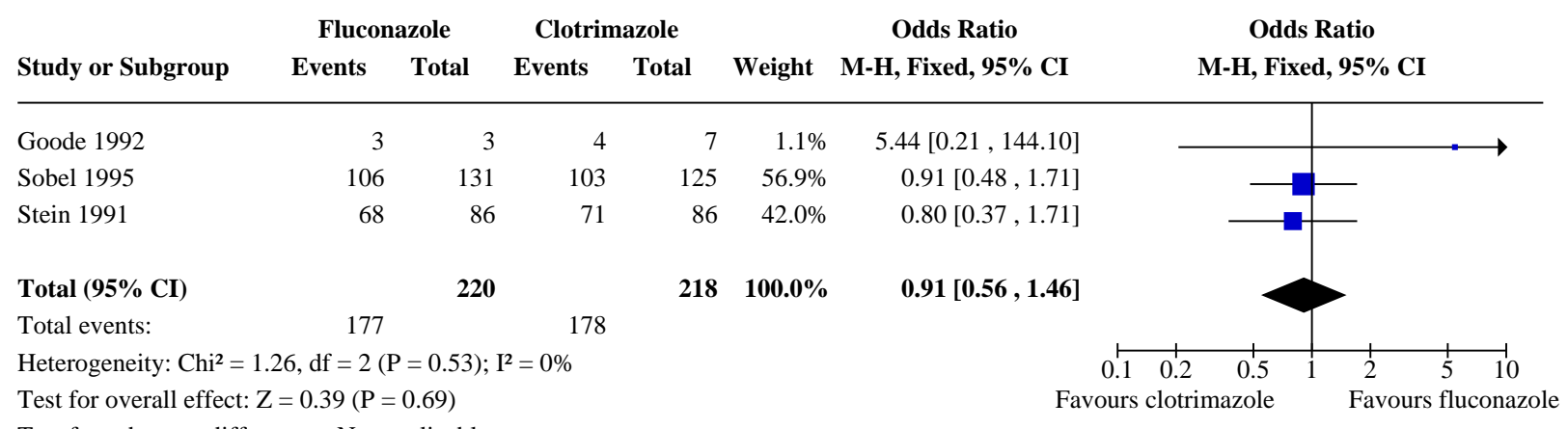

Test for subgroup differences: Not applicable

\section{Analysis 6.2. Comparison 6: Fluconazole versus Clotrimazole, Outcome 2: Long term mycological cure}

\begin{tabular}{|c|c|c|c|c|c|c|c|c|c|}
\hline \multirow[b]{2}{*}{ Study or Subgroup } & \multicolumn{2}{|c|}{ Fluconazole } & \multicolumn{2}{|c|}{ Clotrimazole } & \multirow[b]{2}{*}{ Weight } & \multirow{2}{*}{$\begin{array}{c}\text { Odds Ratio } \\
\text { M-H, Fixed, 95\% CI }\end{array}$} & \multirow{2}{*}{\multicolumn{2}{|c|}{$\begin{array}{c}\text { Odds Ratio } \\
\text { M-H, Fixed, 95\% CI }\end{array}$}} & \\
\hline & Events & Total & Events & Total & & & & & \\
\hline Adetoro 1990 & 20 & 23 & 12 & 20 & $1.9 \%$ & $4.44[0.98,20.07]$ & & & $\rightarrow$ \\
\hline Andersen 1989 & 115 & 160 & 90 & 145 & $30.0 \%$ & $1.56[0.97,2.53]$ & & $\Rightarrow$ & \\
\hline Goode 1992 & 3 & 3 & 4 & 7 & $0.4 \%$ & $5.44[0.21,144.10]$ & & & $\longrightarrow$ \\
\hline Mikamo 1995 & 35 & 50 & 15 & 25 & $6.8 \%$ & $1.56[0.57,4.24]$ & & & \\
\hline O-Prasertsawat 1995 & 32 & 53 & 33 & 50 & $15.2 \%$ & $0.78[0.35,1.75]$ & & - & \\
\hline Sobel 1995 & 90 & 131 & 80 & 125 & $29.0 \%$ & $1.23[0.73,2.08]$ & & - & \\
\hline Stein 1991 & 57 & 74 & 64 & 74 & $16.6 \%$ & $0.52[0.22,1.24]$ & $=$ & - & \\
\hline Total $(95 \%$ CI $)$ & & 494 & & 446 & $100.0 \%$ & $1.25[0.94,1.65]$ & & & \\
\hline Total events: & 352 & & 298 & & & & & & \\
\hline \multirow{2}{*}{\multicolumn{4}{|c|}{ Heterogeneity: $\mathrm{Chi}^{2}=9.73, \mathrm{df}=6(\mathrm{P}=0.14) ; \mathrm{I}^{2}=38 \%$}} & & & & \begin{tabular}{ccc}
$\qquad$ & \multicolumn{1}{|c}{} \\
0.1 & 0.2 & 0.5
\end{tabular} & 2 & 5 \\
\hline & & & & & & Fav & ours clotrimazole & Favours & s fluconazol \\
\hline
\end{tabular}

ADDITIONAL TABLES

Table 1. Duration of follow-up (for primary and/or secondary outcome measures)

\begin{tabular}{|c|c|c|c|c|}
\hline Study & T1 & T2 & T3 & T4 \\
\hline ACCELERATE 2002 & 7 - 10 days & & & \\
\hline Adetoro 1990 & 8 days & 32 days & & \\
\hline Andersen 1989 & 5 - 16 days & 27 - 62 days & & \\
\hline Boag 1991 & 1 - 3 days & 4 - 5 days & 6 - 8 days & $9-12$ days \\
\hline Coric 2006 & 24 hours & 14 days & & \\
\hline Goode 1992 & 2 weeks & 4 weeks & & \\
\hline Mendling 2004 & 2 weeks & 4 weeks & 8 weeks & \\
\hline Mikamo 1995 & 5 - 15 days & 30 - 60 days & & \\
\hline
\end{tabular}

Oral versus intra-vaginal imidazole and triazole anti-fungal treatment of uncomplicated vulvovaginal candidiasis (thrush) (Review) 
Table 1. Duration of follow-up (for primary and/or secondary outcome measures) (Continued)

\begin{tabular}{|c|c|c|c|}
\hline Murina 2012 & 7days & $30-35$ & \\
\hline O-Prasertsawat 1995 & 1 week & 4 weeks & \\
\hline Osser 1991 & 7 - 10 days & 28 - 35 days & $\begin{array}{l}80-100 \\
\text { days }\end{array}$ \\
\hline Roongpisuthipong 2010 & 7 days & 28 days & \\
\hline Sanam 2009 & 10 days & & \\
\hline Seidman 2005 & hourly & & \\
\hline Sekhavat 2011 & 7 days & 1 month & \\
\hline Škerk V 2006 & up to 2 months & & \\
\hline Slavin 1992 & 7 - 14 days & 28 - 34 days & \\
\hline Sobel 1995 & 14 days & 35 days & \\
\hline Stein 1991 & 1 week & 4 weeks & \\
\hline Stein 1993 & 7 - 10 days & 30 - 35 days & \\
\hline Timonen 1992a & 1 week & 2 weeks & \\
\hline Timonen 1992b & 1 week & 1 month & \\
\hline Tobin 1992 & 5 - 10 days & 30 - 40 days & \\
\hline Van Heusden 1990 & 6 - 10 days & 22 - 60 days & \\
\hline Van Heusden 1994 & 7 days & 28 days & \\
\hline Woolley 1995 & $7-10$ days & & \\
\hline
\end{tabular}

Table 2. Sensitivity Analyses

\begin{tabular}{|c|c|c|c|c|}
\hline $\begin{array}{l}\text { Outcome } \\
\text { Measure }\end{array}$ & All comparisons & Selection Bias & Blinded Outcome Assessor & Incomplete Outcome Data \\
\hline $\begin{array}{l}\text { Clinical cure } \\
\text { (short) }\end{array}$ & $\begin{array}{l}14 \text { comparisons, OR 1.14, } \\
95 \% \mathrm{Cl}[0.91,1.43]\end{array}$ & $0 / 14$ comparisons & $\begin{array}{l}\text { 1/14 comparisons, OR } 1.70 \\
95 \% \mathrm{Cl}[0.64,4.55]\end{array}$ & $\begin{array}{l}\text { 12/14 comparisons, OR } 1.22 \text {, } \\
95 \% \mathrm{Cl}[0.95,1.56]\end{array}$ \\
\hline $\begin{array}{l}\text { Clinical cure } \\
\text { (long) }\end{array}$ & $\begin{array}{l}9 \text { comparisons, OR } 1.07 \text {, } \\
95 \% \mathrm{Cl}[0.77,1.50]\end{array}$ & 0/9 comparisons & $\begin{array}{l}1 / 9 \text { comparisons, OR } \\
0.69,95 \% \mathrm{Cl}[0.20,2.41]\end{array}$ & $\begin{array}{l}7 / 9 \text { comparisons, OR } 0.95,95 \% \\
\mathrm{Cl}[0.66,1.38]\end{array}$ \\
\hline $\begin{array}{l}\text { Mycological } \\
\text { cure (short) }\end{array}$ & $\begin{array}{l}20 \text { comparisons, OR 1.24, } \\
95 \% \mathrm{Cl}[1.03,1.50]\end{array}$ & $\begin{array}{l}1 / 20 \text { comparisons, } \\
\text { OR } 0.95,95 \% \mathrm{Cl} \\
{[0.37,2.49]}\end{array}$ & $\begin{array}{l}\text { 1/20 comparisons, OR } 3.55 \text {, } \\
95 \% \mathrm{Cl}[1.29,9.77]\end{array}$ & $\begin{array}{l}15 / 20 \text { comparisons, OR } 1.41 \text {, } \\
95 \% \mathrm{Cl},[1.09,1.82]\end{array}$ \\
\hline
\end{tabular}


Table 2. Sensitivity Analyses (Continued)

$\begin{array}{lllll}\text { Mycological } & 13 \text { comparisons, OR 1.29, } & 1 / 13 \text { comparisons, } & 1 / 13 \text { comparisons, OR } 2.26, & 9 / 13 \text { comparisons, OR } 1.19,95 \% \\ \text { cure (long) } & 95 \% \mathrm{Cl}[1.05,1.60] & \mathrm{OR} 0.78,95 \% \mathrm{Cl} & 95 \% \mathrm{Cl}[0.89,5.74] & \mathrm{Cl}[0.90,1.56], \\ & & & \end{array}$

OR - odds ratio

95\% $\mathrm{Cl}-95 \%$ percent confidence interval

Comparisons had to be rated as low risk of bias for both random allocation and allocation concealment to be included in the selection bias sensitivity analysis. Comparisons for blinded outcome assessor and incomplete outcome data had to be rated as low risk of bias in the respective categories. All sensitivity analyses are reported as odds ratio with $95 \%$ confidence intervals.

\section{APPENDICES}

\section{Appendix 1. MEDLINE, Embase and CENTRAL search strategy update (2015-2018)}

\begin{tabular}{|c|c|}
\hline Database & $\begin{array}{ll}\text { - } & \text { MEDLINE } \\
\text { - } & \text { MEDLINE In-Process \& Other Non-Indexed Citations } \\
\text { - } & \text { MEDLINE Daily Update }\end{array}$ \\
\hline Platform & Ovid \\
\hline Search date & $23 / 05 / 2018$ \\
\hline Range of search date & $2015-2018$ \\
\hline Language Restrictions & None \\
\hline Other Limits & Randomized clinical trials \\
\hline \multirow[t]{14}{*}{ Search strategy (results) } & 1 exp Imidazoles/ (251315) \\
\hline & 2 exp Triazoles/ (33299) \\
\hline & 3 exp Antifungal Agents/ (155439) \\
\hline & 4 (butoconazole or clotrimazole or econazole).tw. (2981) \\
\hline & 5 (fenticonazole or fluconazole or isoconazole).tw. (10938) \\
\hline & 6 (itraconazole or miconazole or omoconazole).tw. (10034) \\
\hline & 7 (oxiconazole or terconazole or tioconazole).tw. (345) \\
\hline & 81 or 2 or 3 or 4 or 5 or 6 or $7(420014)$ \\
\hline & 9 exp Candidiasis, Vulvovaginal/ (3314) \\
\hline & $\begin{array}{l}10 \text { ((vagina } \$ \text { adj } 5 \text { candidosis) or (vulvovagina } \$ \text { adj } 5 \text { candidosis) or (vagina } \$ \text { adj5 mycoses) or (vagi- } \\
\text { na } \$ \text { adj5 candidiasis) or (vulvovagina\$ adj5 candidiasis) or (vagina } \$ \text { adj5 mycoses) or (vagina } \$ \text { adj5 } \\
\text { thrush)).tw. (2281) }\end{array}$ \\
\hline & 119 or $10(4141)$ \\
\hline & 12 randomized controlled trial.pt. (462300) \\
\hline & 13 controlled clinical trial.pt. (92438) \\
\hline & 14 (randomized or randomised).ti,ab. (531453) \\
\hline
\end{tabular}




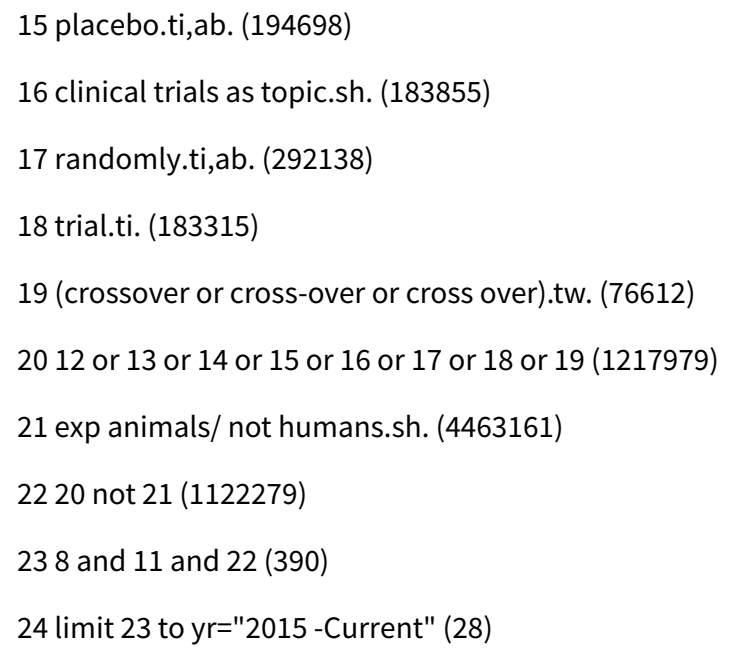

\begin{tabular}{ll}
\hline Database & EMBASE \\
\hline Platform & EMBASE.com \\
\hline Search date & $23 / 05 / 2018$ \\
\hline Range of search date & $2015-2018$ \\
\hline Language Restrictions & None \\
\hline Other Limits & Randomized clinical trials \\
\hline
\end{tabular}

\section{Search strategy (results) $\quad 1$. 'imidazole derivative'/exp (777386)}

2. 'triazole derivative'/exp (147637)

3. 'antifungal agent'/exp (332564)

4. butoconazole:ab,ti OR clotrimazole:ab,ti OR econazole:ab,ti (3908)

5. fenticonazole:ab,ti OR fluconazole:ab,ti OR isoconazole:ab,ti (15085)

6. itraconazole:ab,ti OR miconazole:ab,ti OR omoconazole:ab,ti (13381)

7. oxiconazole:ab,ti OR terconazole:ab,ti OR tioconazole:ab,ti (504)

8. \#1 OR \#2 OR \#3 OR \#4 OR \#5 OR \#6 OR \#7 (1064410)

9. 'vagina candidiasis'/exp (4869)

10. ((vagina* NEAR/5 candidosis):ab,ti) OR ((vulvovagina* NEAR/5 candidosis):ab,ti) OR ((vagina* NEAR/5 candidiasis):ab,ti) OR ((vulvovagina* NEAR/5 candidiasis):ab,ti) OR ((vagina* NEAR/5 mycoses):ab,ti) OR ((vagina* NEAR/5 thrush):ab,ti) (3134)

11. \#9 OR \#10 (5771)

12. 'randomized controlled trial'/de (497851) 
13. 'controlled clinical study'/de (426369)

14. random*:ti,ab (1288799)

15. 'randomization'/de (77741)

16. 'intermethod comparison'/de (234226)

17. placebo:ti,ab (269265)

18. compare:ti OR compared:ti OR comparison:ti (472043)

19. (evaluated:ab OR evaluate:ab OR evaluating:ab OR assessed:ab OR assess:ab) AND (compare:ab OR compared:ab OR comparing:ab OR comparison:ab) (1726872)

20. (open NEAR/1 label):ti,ab (63503)

21. ((double OR single OR doubly OR singly) NEAR/1 (blind OR blinded OR blindly)):ti,ab (207173)

22. 'double blind procedure'/de (148746)

23. (parallel NEXT/1 group*):ti,ab (21432)

24. crossover:ti,ab OR 'cross over':ti,ab (91765)

25. ((assign* OR match OR matched OR allocation) NEAR/5 (alternate OR group* OR intervention* OR patient ${ }^{\star}$ OR subject ${ }^{\star}$ OR participant $\left.\left.{ }^{\star}\right)\right):$ ti,ab (279205)

26. assigned:ti,ab OR allocated:ti,ab (327361)

27. (controlled NEAR/7 (study OR design OR trial)):ti,ab (291068)

28. volunteer:ti,ab OR volunteers:ti,ab (222766)

29. trial:ti249242

30. 'human experiment'/de (404507)

31. \#12 OR \#13 OR \#14 OR \#15 OR \#16 OR \#17 OR\#18 OR\#19 OR \#20 OR \#21 OR \#22 OR \#23 OR \#24 OR \#25 OR \#26 OR \#27 OR \#28 OR \#29 OR \#30 (4260415)

32. \#8 AND \#11 AND \#31 (646)

33. \#8 AND \#11 AND \#31 AND [embase]/lim AND [2015-2018]/py (109)

\section{Number of references identi- 109}

\begin{tabular}{ll}
\hline Database & Cochrane Central Register of Controlled Trials \\
\hline Platform & Ovid \\
\hline Search date & $23 / 05 / 2018$ \\
\hline Range of search date & $2015-2018$ \\
\hline Language Restrictions & None \\
\hline Other Limits & None \\
\hline
\end{tabular}


(Continued)

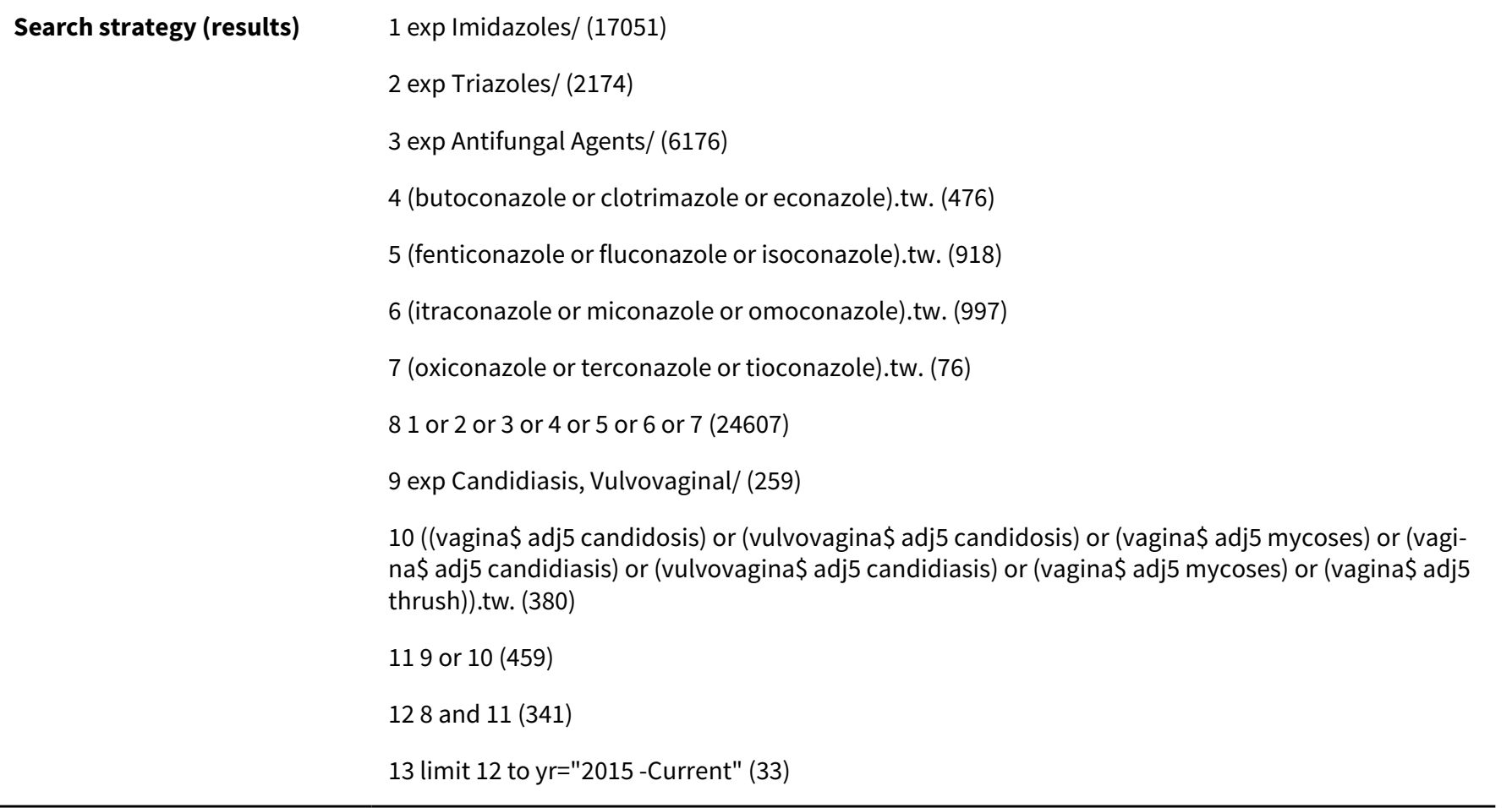

Number of references identi- $\quad 33$

fied

Appendix 2. MEDLINE, Embase and CENTRAL search strategy update (2018-2019)

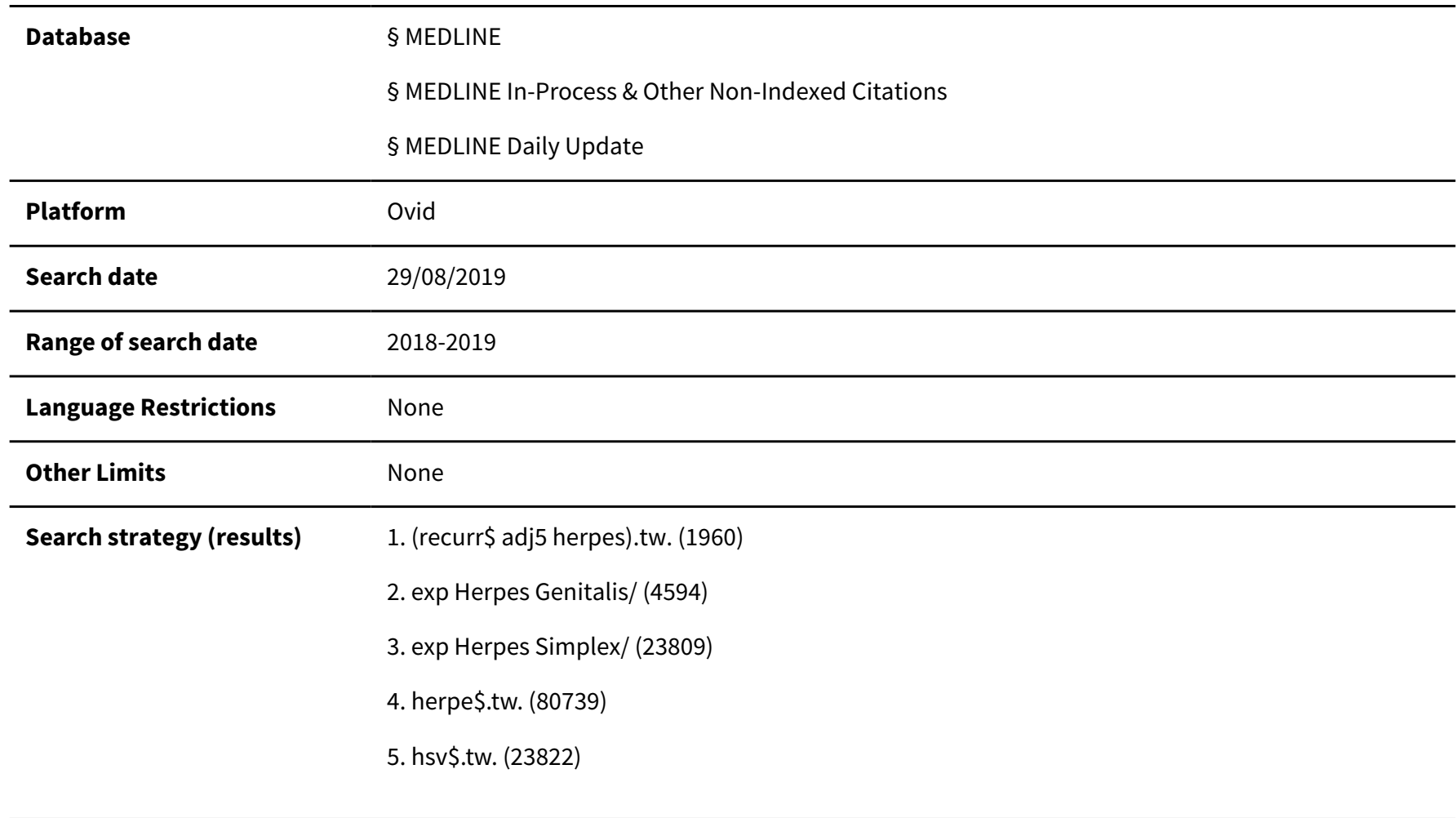


6. or/2-5 (88021)

7. recurr\$.tw. (480861)

8. 6 and 7 (5095)

9. 1 or 8 (5095)

10. (short adj5 therapy).tw. (8549)

11. (short adj5 treatment).tw. (20480)

12. (short adj5 course).tw. (8582)

13. (short adj5 term).tw. (201653)

14. (short adj5 regimen).tw. (901)

15. (short adj5 cycle).tw. (1619)

16. (short adj5 strategy).tw. (1011)

17. (episodic adj5 therapy).tw. (175)

18. (episodic adj5 treatment).tw. (518)

19. (episodic adj5 course).tw. (215)

20. (episodic adj5 regimen).tw. (10)

21. (episodic adj5 cycle).tw. (26)

22. (episodic adj5 strategy).tw. (31)

23. or/10-22 (221262)

24. randomized controlled trial.pt. (487300)

25. controlled clinical trial.pt. (93205)

26. randomized.ab. (400631)

27. placebo.ab. (184378)

28. clinical trials as topic.sh. (188022)

29. randomly.ab. (275513)

30. trial.ti. (178802)

31.24 or 25 or 26 or 27 or 28 or 29 or 30 (1130737)

32. exp animals/ not humans.sh. (4610034)

33. 31 not 32 (1031704)

34.9 and 23 and 33 (55)

35. limit 34 to $y r=" 2015$-Current" (3)

\section{Number of references identi- 7} fied 


\begin{tabular}{ll}
\hline Database & EMBASE \\
\hline Platform & EMBASE.com \\
\hline Search date & $29 / 08 / 2019$ \\
\hline Range of search date & $2018-2019$ \\
\hline Language Restrictions & None \\
\hline (Other Limits & None \\
\hline
\end{tabular}

\section{Search strategy (results)}

1. 'imidazole derivative'/exp (853556)

2. 'triazole derivative'/exp (159845)

3. 'antifungal agent'/exp (355627)

4. butoconazole:ab,ti OR clotrimazole:ab,ti OR econazole:ab,ti (4113)

5. fenticonazole:ab,ti OR fluconazole:ab,ti OR isoconazole:ab,ti (16491)

6. itraconazole:ab,ti OR miconazole:ab,ti OR omoconazole:ab,ti (14377)

7. oxiconazole:ab,ti OR terconazole:ab,ti OR tioconazole:ab,ti (533)

8. \#1 OR \#2 OR \#3 OR \#4 OR \#5 OR \#6 OR \#71161419

9. 'vagina candidiasis'/exp (5196)

10. ((vagina* NEAR/5 candidosis):ab,ti) OR ((vulvovagina* NEAR/5 candidosis):ab,ti) OR ((vagina* NEAR/5 candidiasis):ab,ti) OR ((vulvovagina*NEAR/5 candidiasis):ab,ti) OR ((vagina* NEAR/5 mycoses):ab,ti) OR ((vagina* NEAR/5 thrush):ab,ti) (3366)

11. \#9 OR \#10 (6135)

12. 'randomized controlled trial'/de (564076)

13. 'controlled clinical study'/de (427613)

14. random*:ti,ab (1438163)

15. 'randomization'/de (83269)

16. 'intermethod comparison'/de (252074)

17. placebo:ti,ab (292650)

18. compare:ti OR compared:ti OR comparison:ti (508934)

19. (evaluated:ab OR evaluate:ab OR evaluating:ab OR assessed:ab OR assess:ab) AND (compare:ab OR compared:ab OR comparing:ab OR comparison:ab) (1963716)

20. (open NEAR/1 label):ti,ab (72969)

21. ((double OR single OR doubly OR singly) NEAR/1 (blind OR blinded OR blindly)):ti,ab (223924)

22. 'double blind procedure'/de (164124)

23. (parallel NEXT/1 group*):ti,ab (23905)

24. crossover:ti,ab OR 'cross over':ti,ab (99844) 
25. ((assign* OR match OR matched OR allocation) NEAR/5 (alternate OR group* OR intervention* OR patient ${ }^{\star}$ OR subject* OR participant $\left.\left.{ }^{\star}\right)\right): t i, a b(310834)$

26. assigned:ti,ab OR allocated:ti,ab (364001)

27. (controlled NEAR/7 (study OR design OR trial)):ti,ab (327118)

28. volunteer:ti,ab OR volunteers:ti,ab (238808)

29. trial:ti (283135)

30. 'human experiment'/de (462873)

31. \#12 OR \#13 OR \#14 OR \#15 OR \#16 OR \#17 OR \#18 OR\#19 OR \#20 OR \#21 OR \#22 OR \#23 OR \#24 OR \#25 OR \#26 OR \#27 OR \#28 OR \#29OR \#30 (4735963)

32. \#8 AND \#11 AND \#31 (684)

\#8 AND \#11 AND \#31 AND [embase]/lim AND [2018-2019]/py (55)

Number of references identi- $\quad 55$

fied

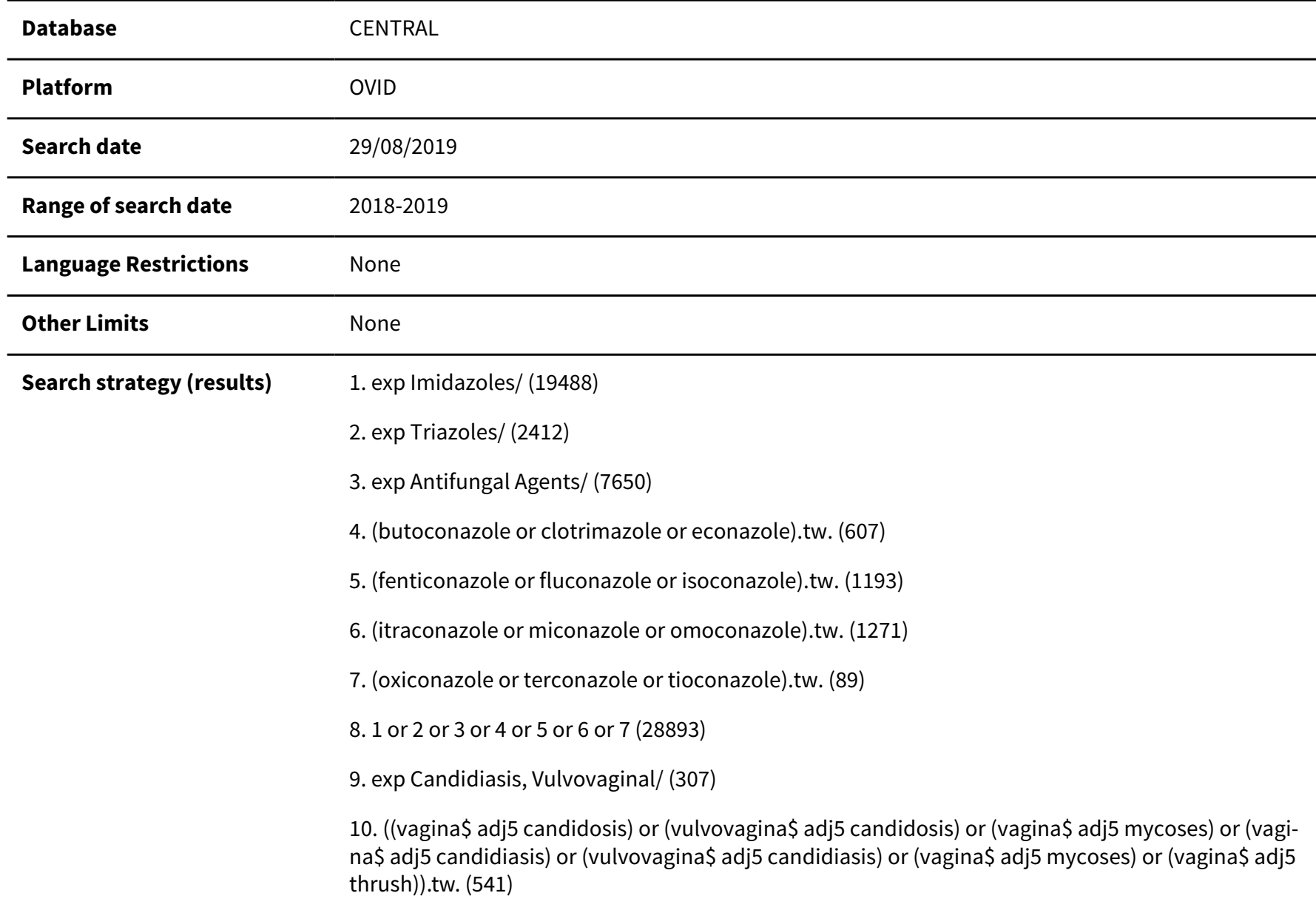

11.9 or $10(627)$ 
13. 13 limit 12 to $y r=" 2018-$ Current" (22)

Number of references identi- $\quad 22$

fied

Appendix 3. Worksheets for grading the certainty of the evidence 


\begin{tabular}{|c|c|c|c|c|c|c|c|}
\hline No of studies & Design & Risk of bias & Inconsistency & $\begin{array}{l}\text { Indirect- } \\
\text { ness[1] }\end{array}$ & Imprecision & Other[2] & $\begin{array}{l}\text { Certainty } \\
\text { (overall } \\
\text { score)[3] }\end{array}$ \\
\hline \multicolumn{8}{|c|}{ Outcome: Clinical cure - short term } \\
\hline 15 & $\mathrm{RCT}$ & $\begin{array}{l}\text { Agreed: main high risk is } \\
\text { due to lack of blinding } \\
\text { of participants and out- } \\
\text { comes Downgrade by -1 } \\
\text { for serious concerns. }\end{array}$ & $\begin{array}{l}\text { Agreed: low concern. While } \\
\text { some heterogeneity around } \\
\text { Analysis } 1.1 .1 \text {, the result is } \\
\text { no effect, which is the over- } \\
\text { all result of the whole analy- } \\
\text { sis. }\end{array}$ & $\begin{array}{l}\text { Agreed: no } \\
\text { concerns and } \\
\text { no downgrad- } \\
\text { ing. }\end{array}$ & $\begin{array}{l}\text { Agreed: minor concern } \\
\text { and no downgrading. } \\
\text { While the confidence } \\
\text { intervals are wide, } \\
\text { they do not extend in- } \\
\text { to a very high or very } \\
\text { low odds ratio (OR) } \\
\text { range. The number of } \\
\text { people in the analysis } \\
\text { is large. }\end{array}$ & None & $\begin{array}{l}\text { Downgrade }-1 \\
\text { to moderate } \\
\text { certainty }\end{array}$ \\
\hline \multicolumn{8}{|c|}{ Outcome: Clinical cure - long term } \\
\hline 9 & $\mathrm{RCT}$ & $\begin{array}{l}\text { Agreed - same issues as } \\
\text { above downgrade -1 }\end{array}$ & $\begin{array}{l}\text { Agreed: low heterogeneity, } \\
\text { no concerns. }\end{array}$ & $\begin{array}{l}\text { Agreed: no } \\
\text { concerns and } \\
\text { no downgrad- } \\
\text { ing }\end{array}$ & $\begin{array}{l}\text { Agreed: same as } \\
\text { above.Minor concern } \\
\text { and no downgrading }\end{array}$ & None & $\begin{array}{l}\text { Downgrade }-1 \\
\text { to moderate } \\
\text { certainty }\end{array}$ \\
\hline \multicolumn{8}{|c|}{ Outcome: Mycological cure - short term } \\
\hline 19 & $\mathrm{RCT}$ & $\begin{array}{l}\text { Agreed: minor concerns } \\
\text { and no downgrading. This } \\
\text { is more of an objective } \\
\text { measure and blinding may } \\
\text { be less important. There } \\
\text { are also some minor con- } \\
\text { cerns about allocation } \\
\text { concealment and selec- } \\
\text { tive reporting. }\end{array}$ & $\begin{array}{l}\text { Agreed: although there is } \\
\text { some heterogeneity present } \\
\text { here, it seems to be mainly } \\
\text { explained by the different } \\
\text { drugs in the comparisons. } \\
\text { Because there is a plausible } \\
\text { explanation for the hetero- } \\
\text { geneity, note as minor con- } \\
\text { cerns. }\end{array}$ & $\begin{array}{l}\text { Agreed: no } \\
\text { concerns and } \\
\text { no downgrad- } \\
\text { ing }\end{array}$ & $\begin{array}{l}\text { Agreed:there are a lot } \\
\text { of people in this analy- } \\
\text { sis, but the confidence } \\
\text { interval includes val- } \\
\text { ues that suggest al- } \\
\text { most no effect to val- } \\
\text { ues that suggest } 50 \% \\
\text { more likely to favour } \\
\text { oral. This is somewhat } \\
\text { imprecise and down- } \\
\text { grade by -1. }\end{array}$ & None & $\begin{array}{l}\text { Downgrade }-1 \\
\text { to moderate } \\
\text { certainty }\end{array}$ \\
\hline
\end{tabular}




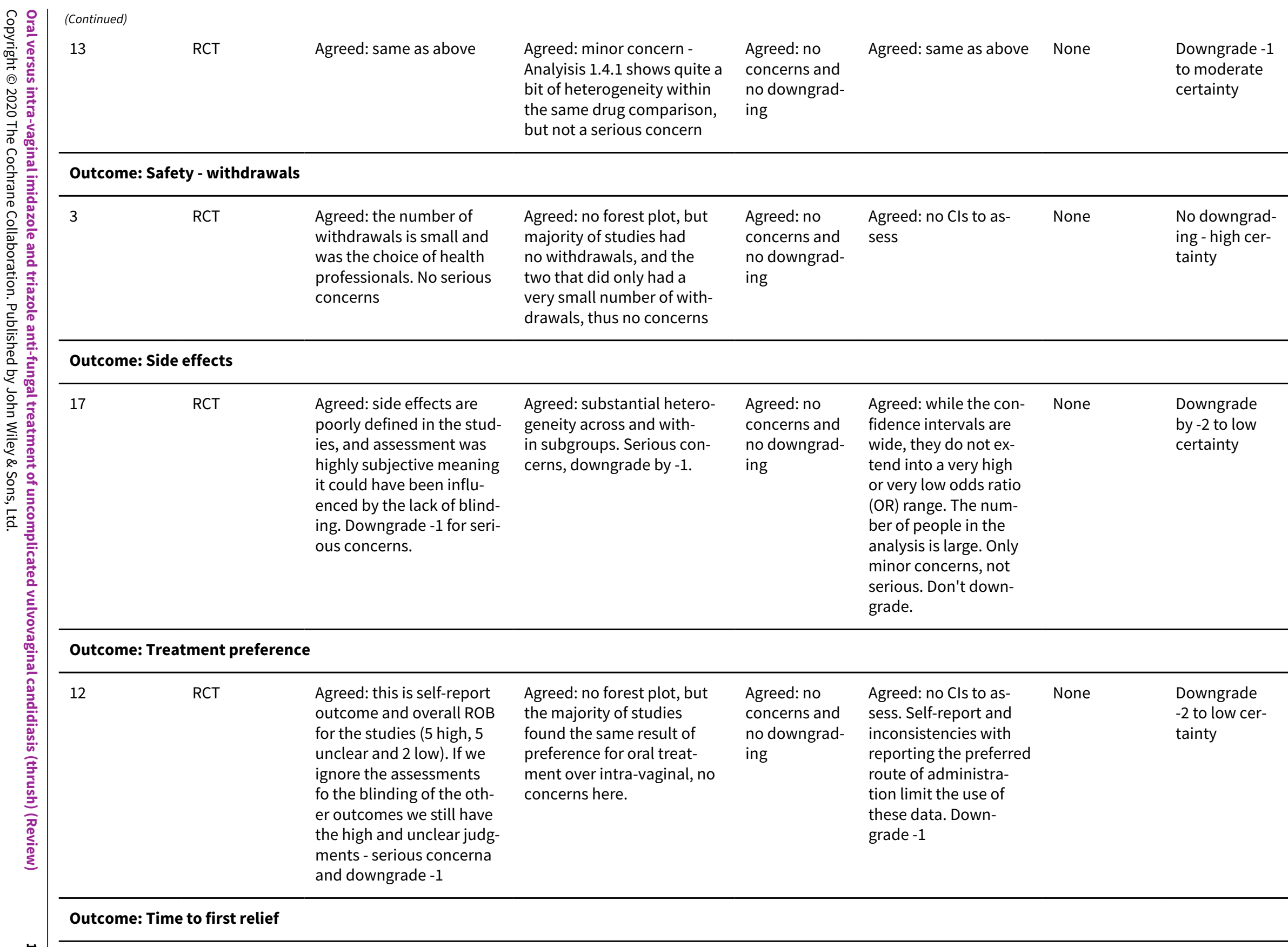




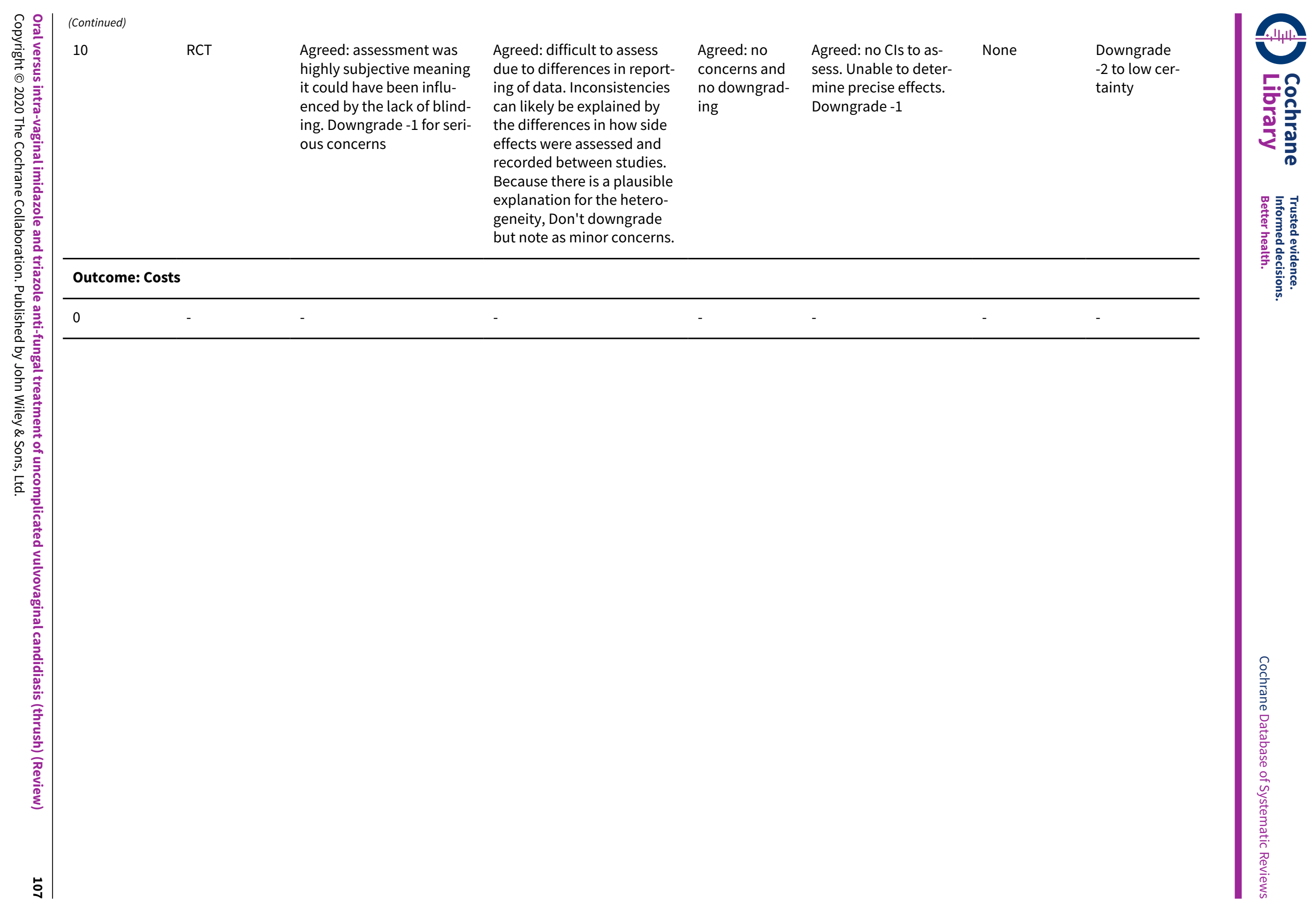


[1] Indirectness includes consideration of:

- - Indirect (between study) comparisons

- ·ndirect (surrogate) outcomes

- Applicability (study populations, interventions or comparisons that are different than those of interest)

[2] Other considerations for downgrading include publication bias. Other considerations for upgrading include a strong association with no plausible confounders, a dose response relationship, and if all plausible confounders or biases would decrease the size of the effect (if there is evidence of an effect), or increase it if there is evidence of no harmful effect (safety)

[3]

Score 4 High certainty= This research provides a very good indication of the likely effect. The likelihood that the effect will be substantially different $^{\star *}$ is low.

Score 3 Moderate certainty $=$ This research provides a good indication of the likely effect. The likelihood that the effect will be substantially different ${ }^{\star *}$ is moderate.

Score 2 Low certainty $=$ This research provides some indication of the likely effect. However, the likelihood that it will be substantially different $^{\star *}$ is high.

Scpre 1 Very low certainty = This research does not provide a reliable indication of the likely effect. The likelihood that the effect will be substantially different** is very high.

${ }^{\star \star}$ Substantially different $=$ a large enough difference that it might affect a decision

\section{WHAT'S NEW}

\begin{tabular}{|c|c|c|}
\hline Date & Event & Description \\
\hline 29 August 2019 & New search has been performed & $\begin{array}{l}\text { This is the second update of the original review. The methods } \\
\text { and searches have been updated to current Cochrane standards. } \\
\text { There have been changes to the authorship with the addition of } \\
\text { six new authors. We searched for studies to } 29 \text { August } 2019 \text { and } \\
\text { identified seven new trials (ACCELERATE 2002; Coric 2006; Muri- } \\
\text { na 2012; Roongpisuthipong 2010; Sanam 2009; Sekhavat 2011; } \\
\text { Škerk V 2006). This review includes } 26 \text { trials. }\end{array}$ \\
\hline
\end{tabular}

29 August $2019 \quad$ New citation required but conclusions have not changed
The addition of new evidence does not change the conclusions of the review. The results of this review should be considered stable in terms of the antifungal medicines included. The frequency of future updates should be limited. No further updates are planned.

\section{HISTORY}

Protocol first published: Issue 4, 2000

Review first published: Issue 1, 2001

\begin{tabular}{lll}
\hline Date & Event & Description \\
\hline 20 October 2015 & Amended & Final updated version submitted to STI group \\
\hline 15 September 2015 & Amended & An additional outcome, time to first relief, was added. \\
\hline 30 June 2015 & New search has been performed & $\begin{array}{l}\text { The review was updated with data identified from searches con- } \\
\text { ducted on 18th June 2015. A new statistically significant differ- }\end{array}$ \\
\hline
\end{tabular}

Oral versus intra-vaginal imidazole and triazole anti-fungal treatment of uncomplicated vulvovaginal candidiasis (thrush) (Review) 


\begin{tabular}{lll}
\hline Date & Event & Description \\
\hline & & $\begin{array}{l}\text { ence was shown with long term mycological cure as a result of } \\
\text { the inclusion of the new studies. }\end{array}$ \\
\hline 11 November 2008 & Amended & Converted to new review format. \\
\hline 22 August 2007 & $\begin{array}{l}\text { New citation required and conclusions } \\
\text { have changed }\end{array}$ & Substantive amendment \\
\hline
\end{tabular}

\section{CONTRIBUTIONS OF AUTHORS}

JMG is the guarantor for this review

HD, JW, MCW and MES undertook duplicate screening and data abstraction

AM, HD, JW and MES completed the risk of bias assessment

$\mathrm{CR}, \mathrm{HD}$, JW and SR performed the GRADE assessment

$A M, C B, H D, J M G, J W, M C W, M E S$ contributed to the preparation of the review manuscript

The original review was conceived by Margaret C Watson (MCW), Jeremy M Grimshaw (JMG) and Christine Bond (CB).The views expressed in this review are those of the authors and may not be shared by the funding organisation.

\section{DECLARATIONS OF INTEREST}

HD: None known

JW: None known

CMB: Has received editor honoraria from Wiley and The Canadian Journal of Hospital Pharmacy; occasional fees from multiple (non pharma) organisations for speaking at meetings, reviewing book proposals; and reimbursement of expenses for travel to meetings

JMG: None known

AM: None known

CR: None known

SR: Awarded internship by University of Aberdeen to work on this project.

MES: None known

MCW: None known

\section{SOURCES OFSUPPORT}

\section{Internal sources}

- Health Services Research Unit, University of Aberdeen, UK

- Clinical Epidemiology Program, Ottawa Hospital Research Institute, The Ottawa Hospital, Canada

(Salary support for Julia Worswick)

- Centre of Academic Primary Care, University of Aberdeen, UK

\section{External sources}

- JMG holds a Tier 1 Canadian Research Chair in Knowledge Transfer and Uptake, Canada

- MCW was funded by a Health Foundation Improvement Science Fellowship and the University of Strathclyde, UK

- The Health Services Research Unit is funded by the Chief Scientist Office, Scottish Executive Health Department, UK

- The Health Economic Research Unit is funded by the Chief Scientist Office, Scottish Executive Health Department, UK 


\section{DIFFERENCES BETWEEN PROTOCOLAND REVIEW}

At the 2020 update we updated the review methods to align with current Cochrane standards and these are now different from those of the published protocol and the last published version of the review (Nurbhai 2007). We used a fixed-effect model only for the meta-analyses. We also added safety and side effects outcomes and have revised the review objective to reflect this. For the 'Risk of bias' assessment, we increased the follow-up requirement from $80 \%$ to $90 \%$ for the incomplete outcome data (attrition bias) criterion. There have been changes to the authorship with the addition of the following new authors: Hayley Denison, Alain Mayhew, Shakila Gnani Ramadoss, Clare Robertson, Mary Ellen Schaafsma and Julia Worswick. Munira Nurbhai, Jill Mollison and Anne Ludbrook did not participate in this update.

\section{INDEX TERMS}

\section{Medical Subject Headings (MeSH)}

Acute Disease; Administration, Intravaginal; Administration, Oral; Antifungal Agents [ ${ }^{*}$ administration \& dosage] [economics]; Candidiasis, Vulvovaginal [ ${ }^{*}$ drug therapy]; Cost-Benefit Analysis; Imidazoles [administration \& dosage] [economics]; Randomized Controlled Trials as Topic; Triazoles [administration \& dosage] [economics]

\section{MeSH check words}

Female; Humans 